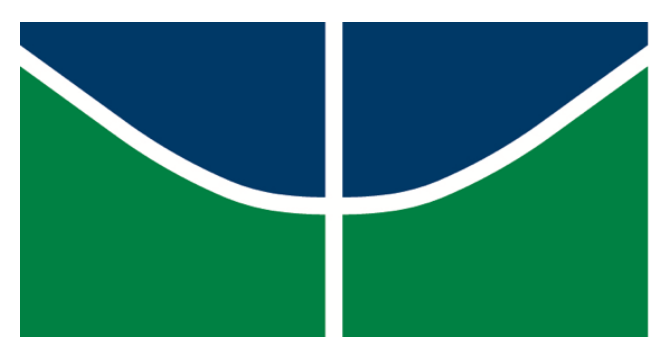

Universidade de Brasília - UnB

Centro de Excelência em Turismo

Thalita Kalix Garcia Santana

\title{
OS INVENTÁRIOS DO PATRIMÔNIO ALIMENTAR BRASILEIRO: POSSIBILIDADES PARA O INCREMENTO DO TURISMO GASTRONÔMICO?
}


THALITA KALIX GARCIA SANTANA

\title{
OS INVENTÁRIOS DO PATRIMÔNIO ALIMENTAR BRASILEIRO: POSSIBILIDADES PARA O INCREMENTO DO TURISMO GASTRONÔMICO?
}

\begin{abstract}
Dissertação apresentada ao Programa de Pós-Graduação em Turismo do Centro de Excelência em Turismo da Universidade de Brasília como requisito para a obtenção do título de mestre. Área de Concentração: Cultura e Desenvolvimento Regional; Linha de Pesquisa: Cultura e Sustentabilidade no Turismo.
\end{abstract}

Orientadora: Profa. Dra. ELOÍSA PEREIRA BARROSO

Brasília 
Ficha catalográfica elaborada automaticamente, com os dados fornecidos pelo(a) autor(a)

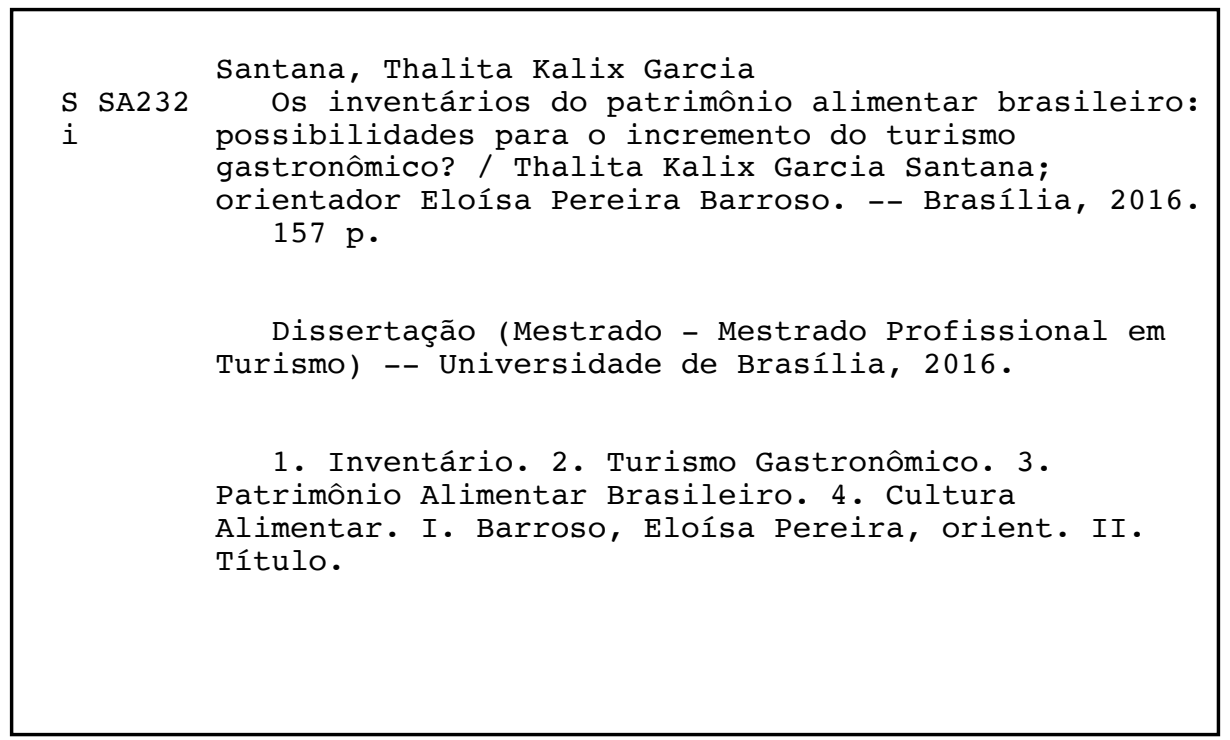


Título: OS INVENTÁRIOS DO PATRIMÔNIO ALIMENTAR BRASILEIRO: POSSIBILIDADES PARA O INCREMENTO DO TURISMO GASTRONÔMICO?

Aluna: Thalita Kalix Garcia Santana

Dissertação apresentada ao Programa de Pós-Graduação em Turismo do Centro de Excelência em Turismo da Universidade de Brasília como requisito para a obtenção do título de mestre. Área de Concentração: Cultura e Desenvolvimento Regional; Linha de Pesquisa: Cultura e Sustentabilidade no Turismo.

Data de aprovação: 06/12/2016

MEMBROS COMPONENTES DA BANCA EXAMINADORA:

Prof. ${ }^{a}$ Dr. ${ }^{a}$ Eloísa Pereira Barroso

Presidente e Orientadora - Universidade de Brasília (UnB)

Prof. ${ }^{a}$ Dr. ${ }^{a}$ Magda de Lima Lúcio

Membro Titular - Universidade de Brasília (UnB)

Prof. ${ }^{\circ}$ Dr. Luiz Carlos Spiller Pena

Membro Titular - Universidade de Brasília (UnB)

Prof. ${ }^{\text {a }}$ Dr. ${ }^{\text {a }}$ Maria Helenice Barroso

Membro Suplente - SEDF

Local: Centro de Excelência em Turismo

UNB - Universidade de Brasília - Campus Universitário Darcy Ribeiro 


\section{AGRADECIMENTOS}

Esta dissertação é mais do que o fruto de um ano e meio de trabalho, ela só pôde se concretizar graças à dedicação de muitas pessoas. Por isso, gostaria de agradecer primeiramente aos meus pais, Pepeu e Yone, que sempre me apoiaram incondicionalmente em meu caminho e em minhas mudanças de direção, e ao meu irmão, Nicola, que está sempre comigo, independentemente da distância.

À professora Eloísa Barroso, por confiar em meu trabalho e aceitar me guiar por essa etapa inicial da vida acadêmica, meu muito obrigada. E em seu nome agradeço a todos os professores que enriqueceram essa jornada de aprendizado.

Aos amigos. Flávia e Nair, minhas irmãs de coração, que são meu porto seguro desde que cheguei em Brasília. Waltinho, amigo que o jornalismo esportivo me trouxe a vida e os projetos nos reaproximaram, obrigada pela força e inspiração. Aos colegas e amigos que o CET me brindou, agradeço a todos pela parceria nesses quase dois anos através das minhas parceiras de noites viradas escrevendo artigo: Tati, Cléa e Mari. Aos companheiros de ativismo do Slow Food, em nome de Jean Marconi, Gabriela Pieroni e Ana Paula Jacques, obrigada pela inspiração e apoio.

E a Gilberto, pelo estímulo em todas as horas, paciência nas de maior stress e pela parceria e amor sempre. 


\section{RESUMO}

O aumento do número de programas de televisão, blogs e sites especializados demonstram um crescimento do interesse da população brasileira pela gastronomia. No entanto, o que se observa, numa análise rápida, é um movimento de homogeneização da alimentação baseado em padrões internacionais e pouca exploração do potencial gastronômico do país pelo turismo. Diante desse cenário, este trabalho analisa os processos de inventariação do Patrimônio Alimentar Brasileiro desenvolvidos pelo IPHAN, INPI e Slow Food, compara-os e analisa como eles são utilizados para o desenvolvimento políticas públicas de fomento do turismo gastronômico no país. Para isso, analisam-se também os projetos e ações voltados a esse segmento desenvolvidos pelos ministérios do Turismo, da Cultura e do Desenvolvimento Agrário. Como sustentação teórica, discute-se a importância da gastronomia como parte da cultura, memória e identidade de uma população, os processos de patrimonialização que se desenvolveram no último século, o papel do turismo nessa relação e as possibilidades para a democratização do patrimônio. Parte-se da metodologia da análise documental para examinar esses inventários e políticas públicas e compará-los. Dessa forma, é possível verificar nossa hipótese de que esses inventários não se comunicam e que, portanto, as ações de promoção do turismo gastronômico no Brasil ainda não os levam em conta.

Palavras-chave: Inventário; Turismo Gastronômico; Patrimônio Alimentar Brasileiro; Cultura Alimentar. 


\begin{abstract}
The increase of TV shows, blogs, and specialized websites shows a rise of Brazilian population interesting for gastronomy. However, in quick analyses, it is possible to observe a food homogenization movement, based on international standards and almost none exploration of the country's gastronomic potential by tourism. Given this scenario, this dissertation analyses the inventory process of Brazilian Food Heritage developed by IPHAN, INPI and Slow Food, compares then and analyses how they are used to improve public policies of food tourism's promotion in Brazil. To achieve that, the projects related to this segment developed by Tourism, Culture and Agrarian Development cabinets are also included in the field of analysis. The importance of gastronomy as part of a population's culture, memory and identity, the heritage's inventory process that took place in the last century, the tourism role in this relation and the possibilities to democratizing the national heritage are discussed as theoretical underpinning. Methodologies of documental analysis were applied to investigate the inventories and public policies. Therefore, it is possible to verify the hypothesis that these inventories do not touch base one with the others, and, consequently, the projects aiming to promote food tourism in Brazil do not take them into account yet.
\end{abstract}

Keywords: Inventory; Food Tourism; Brazilian Food Heritage; Food Culture. 


\section{LISTA DE FIGURAS}

Figura 1. Anúncio de Açaí em Frankfurt, Alemanha, em novembro de 2016............................37

Figura 2. Açaí na Tigela em Praga, República Tcheca - novembro de 2016..............................38

Figura 3. Reprodução da publicação do IPHAN...................................................................... 70

Figura 4. Mapa das Indicações Geográficas do Brasil..............................................................75

Figura 5. Reprodução da capa do dossiề do Ofício das Baianas de Acarajé, IPHAN.................81

Figura 6. Reprodução de página do dossiê do Ofício das Baianas de Acarajé, IPHAN.............82

Figura 7. Reprodução de página do dossiê do Ofício das Baianas de Acarajé, IPHAN..............83

Figura 8. Reprodução de página do dossiê do Ofício das Baianas de Acarajé, IPHAN..............84

Figura 9. Reprodução da capa do dossiê do Modo de Fazer Queijo de Minas, IPHAN.............87

Figura 10. Reprodução de página do dossiê do Modo de Fazer Queijo de Minas, IPHAN.........88

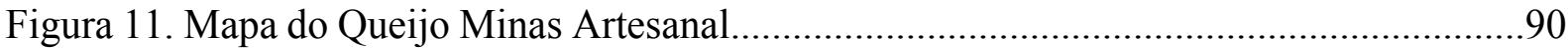

Figura 12. Reprodução da capa do dossiê Produção Artesanal e

Práticas Socioculturais Associadas à Cajuína no Piauí, IPHAN.

Figura 13. Reprodução de página do dossiê Produção Artesanal e

Práticas Socioculturais Associadas à Cajuína no Piaú, IPHAN ..............................................93

Figura 14. Reprodução da Etiqueta de Indicação de Procedência Serro.....................................98

Figura 15. Reprodução do modelo de etiqueta da IG da Canastra............................................102

Figura 16. Reprodução da Etiqueta de Indicação de Procedência da Cajuína do Piauí..............104

Figura 17. Reprodução de páginas da publicação Indicações Geográficas Brasileiras.............107

Figura 18. Reprodução dos dossiês do Queijo da Canastra....................................................109

Figura 19. Reprodução do dossiê da Cajuína com suas versões em inglês

e português no site do Slow Food Internacional.................................................................111

Figura 20. Reprodução da plataforma Oyá Digital...............................................................116

Figura 21. Reprodução do Catálogo da empresa Ideorama.....................................................118

Figura 22. Reprodução de divulgação do Festival Arca do Gosto de 2016..............................121

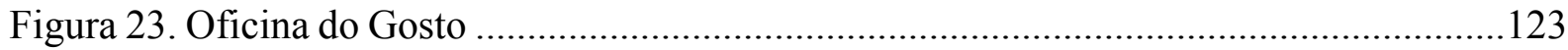

Figura 24. Reprodução de página da publicação 'As metas do Plano Nacional de Cultura'......129

Figura 25. Reprodução da capa de Cartilha desenvolvida no Paraná.......................................132

Figura 26. Reprodução da capa de Cartilha desenvolvida no Ceará........................................133

Figura 27. Reprodução da publicação 'Caminhos do Brasil Rural' ...........................................134

Figura 28. Reprodução da publicação 'Caminhos do Brasil Rural' ...........................................135 


\section{LISTA DE TABELAS}

Tabela 1. Eixos de Ações de Salvaguarda do IPHAN....................................................114-115

Tabela 2. Marco Lógico - Agenda Estratégica e PNT em Ação................................................139 


\section{LISTA DE ABREVIATURAS E SIGLAS}

ABAM Associação Nacional das Baianas de Acarajé, Mingau, Receptivo e Similares

ABNT Associação Brasileira de Normas Técnicas

ACBANTU Associação Cultural de Preservação do Patrimônio Bantu

ADPIC/ Acordo sobre Aspectos dos Direitos de Propriedade Intelectual relacionados ao

TRIPS Comércio

AGRIFERT Associação para Gestão de Projetos de Fortalecimento das Economias Rurais e Desenvolvimento Territorial

ANPAD Associação Nacional de Pesquisa e Pós-Graduação em Administração

ANVISA Agência Nacional de Vigilância Sanitária

APAQS Associação dos Produtores Artesanais de Queijo do Serro

APROCAN Associação dos Produtores de Queijo Canastra

AOC Appellation d'Origine Contrôlée - Apelação de Origem Controlada

Ater Assistência Técnica e Extensão Rural

Caisan Câmara Interministerial de Segurança Alimentar e Nutricional

CCPI/ Centro de Culturas Populares e Identitárias da Secretaria de Cultura do Estado

SECULT

CEN Coletivo de Entidades Negras

CGTR Coordenação Geral de Turismo Responsável do MTur

CNAC Conseil National des Arts Culinaire

CNFCP Centro Nacional de Folclore e Cultura Popular

Consea Conselho Nacional de Segurança Alimentar e Nutricional

DO Denominação de Origem

DPI Departamento de Patrimônio Imaterial do IPHAN

EMATER Empresa de Assistência Técnica e Extensão Rural

FIFA Federação Internacional de Futebol

GT Grupo de Trabalho

IBGE Instituto Brasileiro de Geografia e Estatística

IEHPA Instituto Estadual do Patrimônio Histórico e Artístico de Minas Gerais

IG Indicação Geográfica

IGP Indicação Geográfica Protegida

IMA Instituto Mineiro de Agropecuária

INCRA Instituto Nacional de Colonização e Reforma Agrária 
INPI Instituto Nacional da Propriedade Industrial

INRC Inventário Nacional de Referências Culturais

InvTur Inventário da Oferta Turística

IP Indicação de Procedência

IPAC Instituto do Patrimônio Artístico e Cultural da Bahia

IPHAN Instituto do Patrimônio Histórico e Artístico Nacional

ITS Instituto Terceiro Setor

LPI/96 Lei da Propriedade Industrial 9.279 de 14 de maio de 1996

MAPA Ministério da Agricultura, Pecuária e Abastecimento

MDA Ministério do Desenvolvimento Agrário

MDS Ministério do Desenvolvimento Social

MinC Ministério da Cultura

MTur Ministério do Turismo

NEIM/UFBA Núcleo de Estudos Interdisciplinares Sobre a Mulher da Universidade Federal da Bahia

OMC Organização Mundial do Comércio

ONU Organização das Nações Unidas

PNT Plano Nacional de Turismo

Procajuína União das Associações Cooperativas e Produtores de Cajuínas do Estado do Piauí

PRONAF Programa Nacional de Fortalecimento da Agricultura Familiar

SDT Secretaria de Desenvolvimento Territorial do MDA

SEBRAE Serviço Brasileiro de Apoio às Micro e Pequenas Empresas

SEMOP Secretaria Municipal de Ordem Pública

SEMUR Secretaria Municipal da Reparação

SEPPIR Secretaria de Políticas de Promoção da Igualdade Racial

SEPROMI Secretaria de Promoção da Igualdade Racial

SETRE Secretaria do Trabalho, Emprego, Renda e Esporte

SNIIC Sistema Nacional de Informações e Indicadores Culturais

SPHAN Serviço do Patrimônio Histórico e Artístico Nacional

SPM Secretaria Estadual de Políticas para as Mulheres

TCC Termo de Compromisso Cultural

TRAF Rede de Turismo Rural da Agricultura Familiar

UFs Unidades da Federação 
UFMG Universidade Federal de Minas Gerais

UFSC Universidade Federal de Santa Catarina

UFV Universidade Federal de Viçosa

UNEB Universidade Estadual da Bahia

UNESCO Organização das Nações Unidas para a Educação, a Ciência e a Cultura

Unisig Universidade de Ciências Gastronômicas do Slow Food

UNWTO Organização Mundial do Turismo

WTTC World Travel \& Tourism Council 


\section{SUMÁRIO}

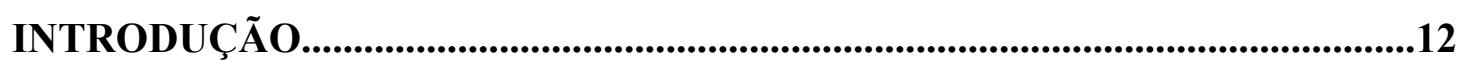

1 DIZE-ME O QUE COMES E TE DIREI QUEM ÉS. CULTURA ALIMENTAR, IDENTIDADE, MEMÓRIA E TURISMO: UM DEBATE TEÓRICO.......16

1.1 A ALIMENTAÇÃO COMO PATRIMÔNIO...............................................................24

2 O TURISMO E A GASTRONOMIA NO MUNDO: POSSÍVEIS INTERLOCUÇÕES...................................................................................................42

2.1 RETORNO AO LOCAL: PONTO DE ENCONTRO DE TURISMO E

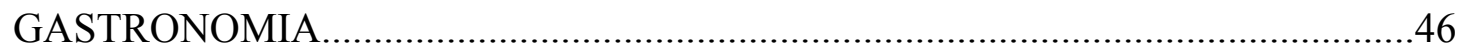

3 A PRODUÇÃO DE SENTIDOS NOS INVENTÁRIOS............................................59

3.1 A SISTEMATIZAÇÃO DOS DOCUMENTOS...........................................................68

3.1.1 As Fichas de Candidatura...................................................................................................69

3.1.2 Os Dossiês dos Bens Inventariados.................................................................................79

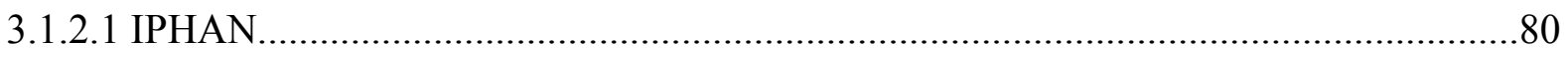

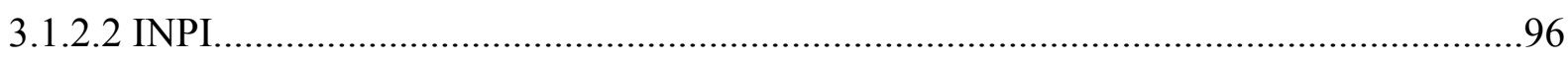

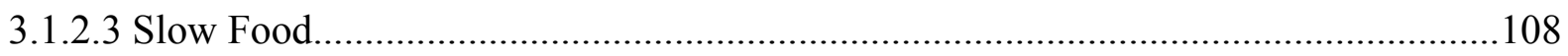

3.2.3 As Ações Complementares............................................................................................113

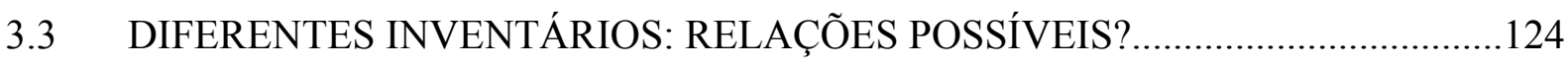

3.4 AS POLÍTICAS PÚBLICAS E OS INVENTÁRIOS: UMA PERSPECTIVA PARA O

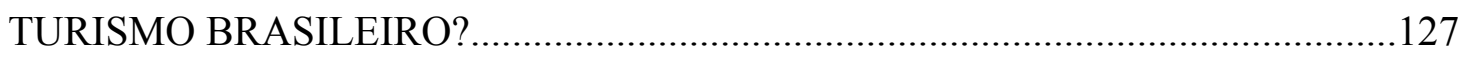

4 CONSIDERAÇÕES FINAIS.....................................................................................147

5 REFERÊNCIAS BIBLIOGRÁFICAS..............................................................151 


\section{INTRODUÇÃO}

É cada dia mais frequente as pessoas viajarem para alguma região ou país com o intuito de conhecer a produção local de vinhos, queijos ou embutidos. Argentina, Chile, Peru, França e Itália são destinos comuns para esse tipo de empreitada e têm como diferencial produtos com certificações de indicação geográfica protegida, mecanismos que asseguram ao turista a origem do produto, único daquela região ou tradição.

No Brasil, os guias turísticos já falam das comidas típicas de cada região desde a década de 1960, mas sempre de forma superficial. Como argumenta o sociólogo Carlos Alberto Dória, na Europa a tipicidade está sempre correlata ao território e o inventariado de pratos típicos foi formulado por equipes multidisciplinares, com estudo da história e do processo de feitura, dando mais força à identidade regional.

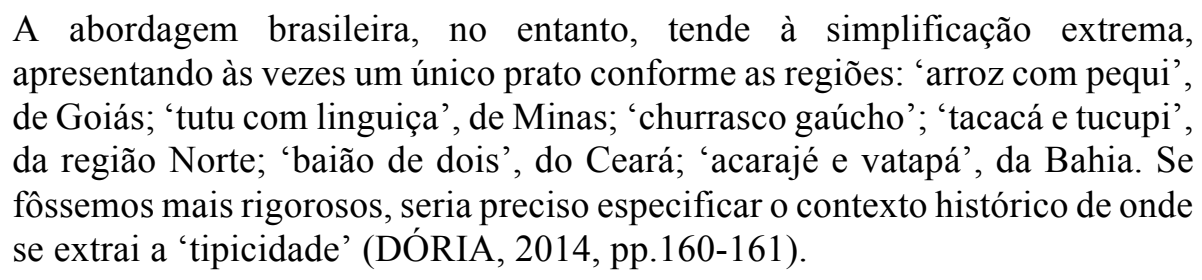

De acordo com pesquisa realizada pelo Ministério do Turismo em 2009 denominada "Hábitos de Consumo do Turismo Brasileiro", a gastronomia local é apenas o sétimo item de importância para os brasileiros escolherem seu destino de viagem pelo próprio país, tendo peso de $2,7 \%$. Entre as atividades realizadas durante a viagem, conhecer pratos e comidas típicas é citado por somente $11 \%$ dos viajantes. Mas com um detalhe interessante: quando o destino é a região Norte, essa passa a ser a segunda atividade mais citada, com 21,4\%, atrás apenas de passeios para conhecer pontos turísticos, com $35,9 \%{ }^{1}$.

Uma das possíveis explicações para essa diferença na região é o fato da culinária amazônica ainda ser tratada como exótica. Por que não criar esse mesmo fascínio por produtos tradicionalmente utilizados pelo Brasil afora e que estão se perdendo? Por tantos preparos e ingredientes que já caracterizaram uma localidade, mas não se encontram mais nas ruas das cidades, que estão restritos a poucas famílias que ainda os produzem e consomem. Como ressalta Susana Gastal: "Hoje, o desconhecido está menos ligado aos territórios - praticamente inexistem no planeta territórios ainda intocados pelos humanos - e mais associado a hábitos

${ }^{1}$ Disponível em: http://www.turismo.gov.br/sites/default/turismo/noticias/todas_noticias/Noticias_download/13.11.09_Pesquisa_ Hxbitos_2009.pdf >. Acessado em: 13 abr. 2016. 
sociais ou a práticas culturais de grupos diferentes daquele do viajante" (GASTAL, 2005, p. $59)$.

O Brasil tem um rico potencial gastronômico a ser explorado. Mas para isso, defende a UNESCO, ele precisa ser sistematizado para que não se perca e que possa ser divulgado. No texto da Organização das Nações Unidas para a Educação, a Ciência e a Cultura denominado “Convenção para a Salvaguarda do Patrimônio Cultural Imaterial”, de 2003, em seu artigo 12, a necessidade de um inventário é evidenciada:

Para assegurar a identificação, com fins de salvaguarda, cada Estado Parte estabelecerá um ou mais inventários do patrimônio cultural imaterial presente em seu território, em conformidade com seu próprio sistema de salvaguarda do patrimônio. Os referidos inventários serão atualizados regularmente (UNESCO, 2006, p. 8).

O IPHAN, atualmente, desenvolve esse programa, mas não foca na cultura alimentar e sim em todas as formas de culturas a serem consideradas patrimônio imaterial. Do outro lado, com um foco mais comercial, existe a catalogação do INPI, que registra os produtos com Indicação Geográfica Protegida (IGP) em duas modalidades: Indicação de Procedência (IP) que protege a relação entre o produto e sua reputação, em razão de sua origem geográfica específica; e Denominação de Origem (DO) - que garante que as qualidades de um produto sejam determinadas, exclusiva ou essencialmente, pelas características daquele lugar, incluídos fatores naturais e humanos.

É preciso, como ressalta Bienassis, aliar os dois objetivos em um só projeto:

Um inventário é uma fonte documental, ele deixa de ser instrumento de preservação uma vez posto a serviço de projetos 'terrenos'. O objetivo 'cultural' é totalmente indissociável do objetivo 'econômico', nenhum inventário não será jamais capaz de impedir o 'desaparecimento progressivo' do menor produto se 'ações específicas' não o seguirem (2011, p. 149, tradução nossa ${ }^{2}$ ).

Fora do escopo do Estado, o Slow Food, uma associação internacional sem fins lucrativos voltada para a defesa de uma alimentação à base de produtos locais, de qualidade e que defendam as tradições e o meio ambiente, reúne em dois projetos, o "Arca do Gosto" e o "Fortalezas", alimentos e saberes ameaçados de extinção.

Essa diversidade de inventários sendo desenvolvidos no Brasil nos motivou a esta pesquisa. As referências mundiais em inventariação do patrimônio alimentar são França e Itália, países que fizeram inventários únicos, com o intuito de incentivar a continuidade de tradições alimentares, utilizando-as como atrativo turístico. Por mais que seja injusto traçar comparações

\footnotetext{
${ }^{2}$ Todas as citações deste texto têm tradução nossa.
} 
entre esses países e o Brasil, por diferenças de território, formação histórica, entre outros fatores, com base nelas, surgiram as seguintes inquietações: há atualmente no Brasil uma política pública de incentivo ao turismo gastronômico? Há alguma relação entre esses diferentes inventários do patrimônio alimentar nacional e o fomento do turismo no país?

Frente a tais questões, esta pesquisa se propôs, portanto, a analisar três processos de catalogação do patrimônio alimentar nacional:

- A Salvaguarda de Bens Imateriais do IPHAN (Instituto de Patrimônio Histórico e Artístico Nacional);

- O registro de Indicação Geográfica Protegida (IGP) do INPI (Instituto Nacional da Propriedade Industrial);

- O projeto "Arca do Gosto" do Slow Food.

Além disso, propôs-se examinar ainda ações e projetos desenvolvidos em 2015/2016 pelos Ministério do Turismo, Ministério da Cultura e Ministério do Desenvolvimento Agrário, que envolvam o incentivo ao turismo gastronômico no Brasil. Assim se pôde verificar se tais inventários são utilizados com esse propósito. Diante desse recorte procuramos estabelecer o objetivo geral da pesquisa:

- Analisar os processos de inventariação de patrimônio imaterial relacionados à alimentação no Brasil, e avaliar como eles são utilizados para o estímulo do turismo gastronômico no país.

Para construir nosso caminho até ele, definimos três objetivos específicos:

- Analisar o processo de concessão de registro de indicação geográfica do INPI; o processo de inventariação de patrimônio imaterial, referente ao patrimônio alimentar, desenvolvido pelo IPHAN; e o processo de catalogação de produtos da "Arca do Gosto", do Slow Food;

- Analisar as ações e projetos desenvolvidos atualmente (2016) do Ministério do Turismo, Ministério da Cultura e Ministério do Desenvolvimento Agrário que envolvam o incentivo ao turismo gastronômico no Brasil;

- Verificar qual a relação entre os inventários e as políticas públicas relacionadas ao turismo gastronômico nas instituições analisadas;

Frente aos objetivos estabelecidos algumas questões se colocaram para o estudo em tela:

- Há alguma relação entre os três diferentes inventários selecionados?

- Quais as funções que eles exercem atualmente? 
- Eles são utilizados como referência para as ações de incentivo ao turismo gastronômico no Brasil?

Nossa hipótese era que esses inventários - assim como os Ministérios em questão - não se comunicam e que, portanto, as ações públicas de promoção do turismo gastronômico ainda não os levam em conta.

Para se chegar à discussão acerca da importância desses processos de inventariação, inicia-se, no primeiro capítulo, pelo debate dos conceitos de cultura, memória e identidade e de como eles se relacionam com a gastronomia, o patrimônio e o turismo. Este trabalho baseia-se, portanto, nas correlações feitas entre os três primeiros conceitos por autores como Clifford Geertz, Stuart Hall, Maurice Halbwachs e Homi Bhabha. Para pôr em perspectiva a construção de uma gastronomia brasileira na modernidade, apoia-se em Jacques Le Goff, Nobert Elias e Carlos Alberto Dória.

Além disso, os processos de inventariação do Patrimônio Cultural Internacional são abordados utilizando-se das perspectivas de Cecília Londres, Nestor García Canclini e do conceito de patrimonialização global, apresentado por Everaldo Costa. Por fim, trata-se da democratização da patrimonialização, baseado em Ana Elisabete Medeiros, Loïc Bienassis e Jean-Pierre Poulain.

No segundo capítulo, delineia-se o processo de formação do turismo, sua relação com a gastronomia e como a valorização do território e do local exerce uma função preponderante nos caminhos de desenvolvimento desses dois fenômenos. Para tanto, baseamo-nos das discussões propostas por Jost Krippendorf, Julia Csergo, Marcos Aurélio Silveira, Rosário Scarpato, JeanPierre Poulain e Alberto Capatti.

Com base nesses debates, parte-se, no terceiro capítulo, para a análise dos três processos de inventariação do patrimônio alimentar desenvolvidos no Brasil, que têm como referencial metodológico a análise documental, apoiado na perspectiva de André Cellard e Lindsay Prior. No momento seguinte, analisar-se-ão as ações desenvolvidas pelos Ministérios do Turismo, da Cultura e do Desenvolvimento Agrário de estímulo ao turismo gastronômico no país, com o intuito de confirmar se as catalogações são ou não utilizadas para esse fim. A partir de toda essa construção, discutimos nas considerações finais, reflexões e perspectivas do Turismo Gastronômico Brasileiro. 


\section{1 "DIZE-ME O QUE COMES E TE DIREI QUEM ÉS"’. CULTURA ALIMENTAR, IDENTIDADE, MEMÓRIA E PATRIMÔNIO: UM DEBATE TEÓRICO}

Antes de discutir qual a relação entre gastronomia e cultura é preciso definir o conceito de cultura utilizado nesta pesquisa. Geertz nos apresenta a cultura como a teia de significados que constitui o homem, ao qual ele está amarrado. Ela seria então formada pela experiência, a vivência cotidiana que constrói significados. E, por isso, é coletiva, uma vez que, a criação de significados acontece na interação com o Outro. Isto é, só é possível construir significados que possam ser reconhecidos coletivamente, ou eles não fazem sentido. Essa ideia se apoia no conceito de alteridade, apresentado por Lévinas (2004), que ressalta a face social do ser humano. Para ele, o sujeito só se reconhece como tal ao se ver no Outro e se perceber diferente. É ao reconhecer as minhas diferenças em relação ao outro que me identifico. E é nessa relação que se constroem as teias de significado da cultura, defende Bauman:

Essa capacidade única de reproduzir e produzir novas estruturas, e não simplesmente a habilidade de introduzir intermediários simbólicos no espaço entre a consciência do evento em si, dota a linguagem humana de seu potencial gerador de cultura e a transforma no verdadeiro alicerce da cultura como fenômeno genérico (2012, p. 146).

O ser humano tem, portanto, uma existência significada no espaço cultural, mas não dissociada do biológico. Ou seja, Geertz corrobora com o pensamento de Bauman ao defender a ideia de que a cultura não é pré-determinada pela natureza, como se acreditava até então. Para o antropólogo norte-americano, a cultura não é dada, mas sim construída socialmente. "Nós somos animais completos e inacabados que nos completamos e acabamos através da cultura não através da cultura em geral, mas através de formas altamente particulares de cultura" (GEERTZ, 1989, p. 36). Isso significa que não se pode falar em uma cultura humana, ou uma cultura homogênea, mas de culturas que se diferenciam de acordo com os grupos sociais pelos quais foram construídas.

Nessa perspectiva, a cultura está associada, necessariamente, às noções de tempo e espaço. Não é possível falar de uma cultura universal. A cultura, uma vez construída socialmente, é particularizada, terá suas variações de acordo com a época e com o território nos quais se insere. Por exemplo, de acordo com essa linha de pensamento, não se pode falar da cultura quilombola de uma forma geral, mas sim da cultura dos Kalungas de Goiás nos dias de hoje ou a cultura dos quilombolas do Mesquita, de Luziânia (GO), na década de 1950.

\footnotetext{
${ }^{3}$ Brillat-Savarin nos aforismos da Fisiologia do Gosto.
} 
Além disso, por ser resultado da construção humana, a cultura, nesta visão, está sempre em transformação. Isto é, por se tratar de uma teia de significados construída pela experiência dos homens em um espaço e tempo específicos (GEERTZ, 1989), a cultura é ressignificada constantemente, ela não é estática ou fixa, como muitas vezes se faz acreditar. Ao contrário, a cultura tem intrínseco em seu processo histórico de construção a permanência, a resistência e as rupturas, nessa tríade pode se afirmar que é imanente à cultura a criação de novos sentidos e a ressignificação das tradições.

[...] a imagem de uma natureza humana constante, independente de tempo, lugar e circunstância, de estudos e profissões, modas passageiras e opiniões temporárias, pode ser uma ilusão, que o que o homem é pode estar tão envolvido com onde ele está, quem ele é e no que ele acredita, que é inseparável deles. É precisamente o levar em conta tal possibilidade que deu margem ao surgimento do conceito de cultura e ao declínio da perspectiva uniforme do homem (GEERTZ, 1989, p. 26).

Portanto, o recorte que utilizamos para tentar responder à questão de qual a relação entre gastronomia e cultura tem espaço e tempos definidos: o Brasil nesse início de século XXI. Vivese numa era que o sociólogo jamaicano Stuart Hall (2006) definiu como modernidade tardia, marcada pela extrema fragmentação da identidade. Nessa perspectiva, é bastante complexo falar sobre uma identidade gastronômica brasileira geral ou harmônica. De acordo com Hall, o sujeito da modernidade tardia se desloca por diferentes identidades, não mais se atendo a uma única, como era na modernidade. Não há mais um único grupo com o qual se identificar, mas vários pelos quais se pode transitar - em um processo em que as diferentes identidades podem ser somadas.

Por outro lado, seguindo essa mesma linha de pensamento, há uma fragmentação excessiva e uma aceleração do tempo, que são características fundamentais da modernidade tardia, e que podem gerar inseguranças no sujeito: não há mais a certeza de se identificar com um único grupo, ao contrário, há infinitas possibilidades de escolhas. Segundo Pierre Nora, é nesse contexto que surge a necessidade do sujeito de se referenciar nas tradições do passado. Trata-se de uma forma de encontrar uma coerência que se perde em um mundo de identidades fragmentadas, a busca de uma materialidade da identidade. "Como não ver, nesse gosto pelo cotidiano no passado, o único meio de nos restituir a lentidão dos dias e o sabor das coisas?" (NORA, 1993, p. 20).

Nesse sentido, para se discutir esse apego ao tempo passado na contemporaneidade, o movimento referenciado nas tradições ganha força no processo de construção de uma identidade cultural. Nessa perspectiva, com o passado e as tradições em evidência, é importante tratar aqui do conceito de memória, pois como argumenta Pollak, "a memória é um elemento constituinte 
do sentimento de identidade, tanto individual como coletiva, na medida em que ela é também um fator extremamente importante do sentimento de continuidade e de coerência de uma pessoa ou de um grupo em sua reconstrução de si” (1992, p. 204). Ou seja, a memória é fundamental no processo de construção das identidades.

Entre essas lembranças estão as gastronômicas. Quando pensamos em cultura alimentar, podem ser despertadas em nós lembranças e inquietudes: como, dentre todos aqueles alimentos degustados ao longo da vida, se escolhe apenas um que define como "aquele" com o qual pessoa se identifica? Para isso o sujeito precisa ativar suas memórias gastronômicas. É pertinente aqui o exemplo desse processo de memória ligada à gastronomia encontrado quando Proust descreve, com extrema riqueza de detalhes, as madeleines que, ao serem saboreadas o fazem se transportar ao passado ${ }^{4}$. Esse trecho deixa claro toda a complexa teia que envolve o ato de comer, e como a escolha e usos dos ingredientes dizem respeito à ligação com o território e às relações sociais.

Se, para Lévinas e Geertz a formação da identidade de um sujeito nasce da alteridade, Halbwachs (1990) e Ricoeur (2007) reafirmam esta ideia ao considerar que ela depende, fundamentalmente, do grupo com o qual esse sujeito se identifica. Os dois autores tratam com profundidade do conceito de memória coletiva. Mas, antes de chegarmos a ele, é necessário

\footnotetext{
4 “Quando, por um dia de inverno, ao voltar para casa, vendo minha mãe que eu tinha frio, ofereceu-me chá, coisa que era contra meus hábitos. A princípio recusei, mas, não sei por que, terminei aceitando. Ela mandou buscar um desses bolinhos pequenos e cheios chamados madalenas e que parecem moldados na valva estriada de uma concha de São Tiago. Em breve, maquinalmente, acabrunhado com aquele triste dia e a perspectiva de mais um dia tão sombrio como o primeiro, levei aos lábios uma colherada de chá onde deixara amolecer um pedaço de madeleine. Mas no mesmo instante em que aquele gole, de envolta com as migalhas do bolo, tocou meu paladar, estremeci, atento ao que se passava de extraordinário em mim. Invadira-me um prazer delicioso, isolado, sem noção de sua causa. Esse prazer logo me tornara indiferente às vicissitudes da vida, inofensivos seus desastres, ilusória sua brevidade, tal como o faz o amor, enchendo-me de uma preciosa essência: ou, antes, essa essência não estava em $\mathrm{mim}$, era eu mesmo. Cessava de me sentir medíocre, contingente, mortal. De onde me teria vindo aquela poderosa alegria? Senti que estava ligada ao gosto do chá e do bolo, mas que o ultrapassava infinitamente e não devia ser da mesma natureza.

[...]E de súbito a lembrança me apareceu. Aquele gosto era o do pedaço de madeleine que nos domingos de manhã em Combray (pois nos domingos eu não saía antes da hora da missa) minha tia Léonie me oferecia, depois de o ter mergulhado em seu chá da Índia ou de tília, quando ia cumprimentá-la em seu quarto. O simples fato de ver a madeleine não me havia evocado coisa alguma antes que a provasse; talvez porque, como depois tinha visto muitas, sem as comer, nas confeitarias, sua imagem deixara aqueles dias de Combray para se ligar a outros mais recentes; talvez porque, daquelas lembranças abandonadas por tanto tempo fora da memória, nada sobrevivia, tudo se desagregara; as formas - e também a daquela conchinha de pastelaria, tão generosamente sensual sob sua plissagem severa e devota - se haviam anulado ou então, adormecidas, tinham perdido a força de expansão que lhes permitiria alcançar a consciência.

[...]E mal reconheci o gosto do pedaço de madeleine molhado em chá que minha tia me dava (embora ainda não soubesse, e tivesse de deixar para muito mais tarde tal averiguação, por que motivo aquela lembrança me tornava tão feliz), eis que a velha casa cinzenta, de fachada para a rua, onde estava seu quarto, veio aplicar-se, como um cenário de teatro, ao pequeno pavilhão que dava para o jardim e que fora construído para meus pais aos fundos dela (esse truncado trecho da casa que era só o que eu recordava até então); e, com a casa, a cidade toda, desde a manhã à noite, por qualquer tempo, a praça para onde me mandavam antes do almoço, as ruas por onde eu passava e as estradas que seguíamos quando fazia bom tempo." (PROUST, 2006, p. 47)
} 
ressaltar que a memória, nessa corrente de pensamento, é sempre considerada como fragmentada. Ou seja, Halbwachs (1990) é um dos autores da teoria da memória a defender que não existe uma memória integral do passado. Para ele, o sujeito não consegue se recordar na totalidade de todos os acontecimentos que viveu. O que ele se lembra são apenas trechos, fragmentos, ou vestígios que são reordenados no momento em que são recordados e representam o passado no presente. É um sabor, um cheiro - um fragmento de lembrança - que se reordena no presente com outros 'pedaços' de memória e formam a recordação.

A memória, desse ponto de vista, é sempre ressignificada. Isto porque, de acordo com Halbwachs (1990) e Ricoeur (2007), cada vez que recordamos uma lembrança, que fazemos o movimento de trazê-la do passado para o presente, a ressignificamos, pois ela é colocada e revivida em outro contexto, em outro tempo e espaço. Não é mais aquele momento que foi vivido, mas sim uma representação daquele passado. Ricoeur argumenta que, o presente é muito fluido, o agora já virou passado, e, por isso, a memória é o passado com perspectiva de permanência para o futuro. "A busca da lembrança comprova uma das finalidades principais do ato de memória, a saber, lutar contra o esquecimento, arrancar alguns fragmentos de lembrança à 'rapacidade' do tempo (Santo Agostinho dixit), ao 'sepultamento' no esquecimento" (RICOEUR, 2007, p. 48).

Como ressaltam os dois autores, não dá para se falar em memória individual pura, pois toda memória é, no mínimo, regida por signos ou imagens, que são formados socialmente. A memória é, portanto, constituída de lembranças, imagens, de sentimentos, que se referem, de alguma forma, a outras pessoas. A nossa memória individual é, nessa perspectiva, ligada à memória coletiva do grupo ou dos grupos dos quais fazemos parte. Quando Proust se recorda de seu passado ao degustar uma madeleine, sua tia, os prédios, a rua, cores e sabores, todas essas construções sociais são evocadas. E é como se ele voltasse a experimentar toda aquele passado novamente, no presente.

Ao mesmo tempo, nesse sentido, não se pode falar em memória coletiva sem memória individual. A memória de um grupo vive nas memórias individuais de cada um de seus integrantes. Por isso, explica Halbwachs (1990), existem tantas memórias coletivas quanto grupos. Esses são dos mais variados. Durante a vida, o sujeito pertence a diversos grupos: o primeiro de todos é a família; depois vêm os vizinhos, os amigos de escola, os colegas de trabalho, entre outros. Pode-se fazer parte de diversos grupos ao mesmo tempo. As memórias de cada grupo estão, no entanto, defende Halbwachs, intrinsecamente ligadas à coletividade. Assim, uma vez que o sujeito deixa de fazer parte daquele grupo, suas memórias daquele período são esquecidas e só podem ser recordadas no encontro com outros indivíduos que 
participavam daquele mesmo núcleo. Dessa forma, a memória individual é ressignificada a partir da memória coletiva.

Mas para se recordar de algo, geralmente, precisa-se de um gatilho que dispare a busca pela lembrança: pode ser o encontro com alguém do grupo a que pertencemos, uma imagem, uma data comemorativa, etc. Na memória coletiva Halbwachs denominou esses gatilhos de lugares de memória. Eles "funcionam principalmente à maneira dos reminders, dos indícios de recordação, ao oferecerem alternadamente um apoio à memória que falha, na luta contra o esquecimento, até mesmo uma suplementação tácita da memória morta" (RICOEUR, 2007, p. 58). É nessa ênfase aos pontos de referência que estruturam a memória coletiva, entre os quais se destacam os lugares de memória, que a gastronomia aparece.

Entre eles incluem-se evidentemente os monumentos, esses lugares da memória analisados por Pierre Nora, o patrimônio arquitetônico e seu estilo, que nos acompanham por toda a nossa vida, as paisagens, as datas e personagens históricas de cuja importância somos incessantemente relembrados, as tradições e costumes, certas regras de interação, o folclore e a música, e, por que não, as tradições culinárias (POLLAK, 1989, p. 3).

Preparos, sabores e aromas são, portanto, lugares de memórias de grupos diversos. Quem nunca se recordou da casa da infância ao sentir o cheiro da comida que a mãe preparava? $\mathrm{Ou}$ ao rememorar o passado vivido não sentiu sabores degustados naquela época? A gastronomia está, nessa perspectiva, extremamente ligada à cultura, memória e identidade dos grupos. Cada coletividade da qual fazemos parte tem suas particularidades gastronômicas, sua identidade. Associamos diferentes tipos de preparos e alimentos a cada um dos grupos que fizemos ou fazemos parte. "A alimentação é, por vezes, o suporte de uma identidade que nós pretendemos defender e um recurso a preservar em nome da diversidade cultural" (BIENASSIS, 2011, p.132). E é nesse ensejo que os inventários do patrimônio alimentar se justificam, na busca pela manutenção de tais lugares de memória.

Ainda nessa linha de pensamento, Pollak defende que a memória é herdada, pois ela tem forte conexão com o grupo primeiro que o sujeito participa, a família, e está conectada ao sentimento de coerência, de identidade. "Nas lembranças mais próximas, aquelas de que guardamos recordações pessoais, os pontos de referência geralmente apresentados nas discussões são, como mostrou Dominique Veillon, de ordem sensorial: o barulho, os cheiros, as cores" (POLLAK, 1989, p. 11). De acordo com esse conceito, pode-se falar que um grupo tem uma cultura alimentar específica? Mais especificamente em relação ao Brasil seria possível se definir uma identidade gastronômica brasileira? Se sim, que preparo representaria a culinária de todo o país? 
Em face das questões colocadas é essencial retomar aqui os estudos da memória. Quando se fala de memória coletiva refere-se a um grupo restrito, geralmente pequeno. Tratar de memória nacional, é muito mais do que apenas somar todas as memórias coletivas. Nesse processo de definição da memória nacional há uma seletividade de que memórias serão salvaguardadas e quais serão ignoradas, abandonadas ao esquecimento. Usualmente esse tipo de seleção é feita pelos sujeitos que têm poder de decisão (e poder político), e, como todos sujeitos sociais, têm suas intencionalidades, conscientes ou inconscientes. Pode-se dizer que a tentativa de construção pelo Estado de uma memória nacional faz parte de um movimento de autorrepresentação.

Assim, nem todas as memórias coletivas farão parte das lembranças oficiais. Geralmente, poucas fazem. O que ocorre, é uma tendência a se homogeneizar as memórias para se "criar" uma memória nacional. Bhabha (2003) defende que a identidade nacional existe muito mais como discurso do que no cotidiano, pois a fala oficial nacionalista privilegia uma visão, como se todos fossem um só, ignorando as pluralidades e particularidades existentes no seio do país. E qual seria então o discurso de identidade nacional gastronômica construída no Brasil?

Para chegar a essa construção é preciso contextualizar o problema: na modernidade. Em seu livro "História e Memória", Jacques Le Goff apresenta três diferentes tipos de modernização:

a) a modernização equilibrada, em que o êxito da penetração do 'moderno' não destruiu os valores do 'antigo', que tem como exemplo o Japão, país que manteve suas tradições ao mesmo tempo que se modernizou; b) a modernização conflitual que, atingindo apenas uma parte da sociedade, ao tender para o 'moderno', criou conflitos graves com as tradições antigas, que pode se citar como exemplo algumas nações muçulmanas na África; e c) a modernização por tentativas que, sob diversas formas, procura conciliar 'moderno' e 'antigo', não através de um novo equilíbrio geral, mas por tentativas parciais (LE GOFF, 1990, p. 185).

Nessa linha de análise, podemos dizer que o Brasil passou por um processo de modernização por tentativas. Isto é, a modernização ainda não foi completamente efetivada no país: a modernidade (ou até mesmo a pós-modernidade ou modernidade tardia) convivem com o antigo. Ao mesmo tempo, nesse processo, percebe-se que a modernização foi bastante valorada - ao passo em que o antigo foi depreciado - o que pode ser notado já com o lema da bandeira nacional "ordem e progresso". O Brasil assumiu, desde fins do século XIX, o discurso romântico de "país do futuro", o que pode ter corroborado para que a ideologia de uma modernização necessária, em oposição ao antigo, à tradição, ganhasse força em alguns aspectos da vida social. 
Nesse sentido, o conceito francês de civilisation, explicado por Nobert Elias (1994) em “O processo civilizador", pode ser visto como um fator influente para o discurso de progresso nacional. Assim como a maior parte dos países ocidentais, o Brasil se inspirou no conceito nascido na França de que a cultura era estratificada: haviam culturas maiores e menores e, claramente, a cultura da aristocracia francesa, estava acima de todas. E os costumes do país europeu, nesse movimento, passaram a serem imitados mundo afora. $\mathrm{O}$ francês, era a língua a ser estudada.

Nesse contexto, a necessidade de ser reconhecido como um povo "civilizado" exigia que os brasileiros renegassem tudo que fosse "bárbaro", quer dizer, tudo que não fosse condizente com a cultura europeia. Um país moderno deveria ter uma "alta cultura". Nesse escopo, a gastronomia popular tradicional, de origem indígena, negra e pobre foi desvalorizada durante séculos. Civilizado e chic era a culinária francesa. Assim a gastronomia europeia passa a dominar as mesas da burguesia nacional.

De fato, ainda hoje é bastante conveniente a ideia de que somos mestiços no prato, mesmo que a maior parte das comidas populares não seja aceita em mesas cultas e elitizadas. E é trabalhando com essas heranças, atenuando seus aspectos mais estranhos, que vamos construindo uma nova cozinha brasileira; afinal, precisamos cada vez mais desse mito num ambiente internacionalizado e competitivo, pois, sem ele, o que seríamos, comparativamente? (DÓRIA, 2014, p. 43)

Pode-se dizer, nessa linha de pensamento, que durante alguns séculos, optou-se por valorizar uma memória gastronômica burguesa, de inspiração europeia. Ao passo que a identidade gastronômica popular foi colocada num patamar de "cultura menor". Esse processo só começa a se inverter, ligeiramente, nos últimos anos, como parte de um movimento global de valorização das particularidades e, consequentemente, das localidades, perceptível nos processos de patrimonialização e inventariação das tradições alimentares. Como ressalta o sociólogo Carlos Alberto Dória:

No período do nacionalismo, contrapunha-se uma 'cozinha brasileira' a uma
'cozinha francesa' ou afrancesada que nos remetia para fora do universo de
nossas vivências mais imediatas. E dessa cozinha brasileira eram tributárias
todas as cozinhas regionais. Recentemente, contudo, assiste-se à emergência
de um localismo extremo, com a atenção e a ênfase voltadas para os terroirs
e as demarcações de origem de determinados produtos (DOCS, AOCS etc.).
Estas podem, inclusive, se sobrepor às denominações nacionais, mostrando
como 'território' é um conceito histórico de poder explicativo bastante
variável (2014, p.140).

Retoma-se, assim, a ideia de Nora de que, na sociedade de modernidade tardia, fragmentada e acelerada, há um movimento de busca por uma identidade material que nos devolva a certeza e a lentidão dos tempos passados. É o que o historiador francês denomina de 
desejo de memória: um reflexo da mundialização, da hegemonia do efêmero ${ }^{5}$. Por outro lado, essa busca pela revalorização das tradições culinárias também pode ser vista como uma resistência à tendência de homogeneização resultante da globalização acelerada. Ou ainda, como uma forma de diferenciar-se em um mercado gastronômico internacional saturado, em um processo de produção de singularidades que pode ser percebido como um movimento presente em todas as esferas no mundo atual.

Mas a influência do processo de modernização do Brasil, do progresso, pode ter influenciado ainda mais às tradições alimentares da população do que se dê conta em uma primeira análise. Isso porque um dos reflexos da modernidade foi a delimitação do tempo de lazer e a inserção da mulher no mundo do trabalho. Com jornada dupla - trabalhando fora e em casa, a mulher passa a ter menos tempo para se dedicar à cozinha, local que sempre foi seu na tradição do país, e precisa de alimentos mais práticos. A industrialização da alimentação cresce vertiginosamente em todo o ocidente durante o século XX.

Isso pode ter impactado diretamente na construção de memórias gastronômicas locais, uma vez que as famílias foram, influenciadas por essa industrialização, mudando seus hábitos alimentares, paulatinamente. Assim, comer direto da lata passa a ser visto como bom e naturalizado. E com os costumes alimentares, vai se alterando o gosto.

Outro ponto a ser levado em conta da influência da modernização na identidade gastronômica nacional é o processo de urbanização. É durante a modernidade que a migração do campo para a cidade se acelera. Com o esvaziamento dos campos e o adensamento da malha urbana das cidades, nota-se uma perda dos hábitos de cultivo e extração de hortaliças, frutas e leguminosas. Se no início do século passado era bastante comum as pessoas, mesmo na cidade, manterem o contato com a terra através de quintais com hortas e pomares, isso foi se rareando. Atualmente é possível perceber uma tendência de retomada desses costumes. Mas ainda em pequena escala. Não é incomum, entretanto, nos dias de hoje, encontrar jovens que nunca tenham visto um legume in natura. E isso necessariamente influencia na percepção da população em relação à tradição gastronômica nacional.

Por fim, com a aceleração do ritmo de vida, o "sentar-se à mesa" com a família para partilhar uma refeição deixa de ser uma regra para tornar-se uma exceção. As refeições rápidas, fast food, passam a fazer parte do hábito alimentar ocidental. Na falta de tempo, come-se rapidamente. Nesse contexto, a culinária tradicional, fortemente ligada ao solo, ao território, ao tempo da natureza, perde força. É frente a esse processo que movimentos surgem com o intuito

\footnotetext{
5 Conceito que Bauman define como fluidez do mundo.
} 
de retomar a valorização da alimentação saudável, de ingredientes locais, que valorizem o saber-fazer daquele território, pois este está ameaçado, uma vez que não é mais transmitido de geração para geração.

Dessa forma, percebe-se que a industrialização e suas consequências sociais, de delimitação do tempo de lazer, de aceleração da vida cotidiana, são determinantes na construção de uma gastronomia brasileira.

\subsection{A ALIMENTAÇÃO COMO PATRIMÔNIO}

Ao tratar desse processo de construção de uma gastronomia brasileira voltamos a um persistente impasse: a que gastronomia nos referimos? Se a ideia de uma identidade nacional homogênea é uma imposição (mesmo quando é apropriada por boa parte da população), como tratar de uma culinária brasileira sem sermos excludentes?

Historicamente, a gastronomia nacional foi regionalizada. Observando a divisão dos estados da Federação, elegiam-se os "pratos típicos" de cada localidade. Esse tipo de opção pode ser verificada no Guia 4 Rodas, como exemplificado há pouco. Esse processo de definição de pratos típicos regionais, no entanto, acaba desrespeitando as singularidades locais e o processo histórico de construção dos significados em torno de tal preparo. Trata-se, retomando o conceito de Bhabha (2003) de formação de uma memória nacional, de uma imposição de cima para baixo.

A relação entre identidade e tipicidade é muito forçada, pois a tipificação não retém a riqueza cultural na qual os pratos, um dia, estiveram imersos. Ao simplificar a relação da comida com a cultura em sentido amplo, dá-se uma caricaturização desta última, fazendo com que os próprios consumidores locais já não mais a reconheçam como autêntica (DÓRIA, 2014, p. 166).

O desafio, então, é compreender toda a teia de significados que formam as tradições gastronômicas do país, para além do pré-estabelecido de que a culinária brasileira é fruto da miscigenação das culturas indígenas, africana e portuguesa, ressalta o sociólogo:

Como é corrente até mesmo na sociologia, firmou-se a ideia de que os pratos nacionais se fixaram pela aplicação de ingredientes nativos às receitas seculares, ou pela assimilação de 'receitas' indígenas e africanas a técnicas e ingredientes trazidos pela mão portuguesa. A ideia dessa miscigenação culinária, ou mistura entre ingredientes e técnicas de diferentes procedências, que se materializaria num cardápio partilhado pelos brasileiros, é uma abordagem simplista para uma realidade tão complexa (DÓRIA, 2014, p. 23).

A gastronomia é, portanto, intrinsecamente relacionada com a cultura. Mas é muito fácil cair numa simplificação de qual é essa cultura gastronômica brasileira. Para se falar de uma gastronomia brasileira é preciso levar em conta as singularidades de sua formação em cada 
localidade do país, dentro de cada grupo identitário e não apenas seguindo as divisões políticas nacionais. Pode-se considerar o Brasil um país multicultural na definição de Hall (2003, p. 52), que vive, desde a sua formação um processo de hibridização. "O hibridismo não se refere a indivíduos híbridos, que podem ser contrastados como 'tradicionais' e 'modernos' como sujeitos formados. Trata-se de um processo de tradução cultural, agonístico uma vez que nunca se completa, mas que permanece em sua indecibilidade" (HALL, 2003, p. 74).

Assim, o desafio do multiculturalismo no Brasil é a forma como se lida com o encontro e a tradução das diferentes culturas intrínsecas à formação da gastronomia nacional. Como destaca Bhabha,

Os próprios conceitos de culturas nacionais homogêneas, a transmissão consensual ou contígua de tradições históricas, ou comunidades étnicas 'orgânicas'- enquanto base do comparativismo cultural -, estão em profundo processo de redefinição. [...] Gosto de pensar que, do lado de cá da psicose do fervor patriótico, há uma evidência esmagadora de uma noção mais transnacional e translacional do hibridismo das comunidades imaginadas (2003, p. 24).

O processo de revalorização do tradicional, da busca pela territorialidade e pela memória herdada, tem de levar em conta todas as nuances da complexa construção da culinária. Não se pode continuar apegado a uma ideia de gastronomia brasileira universal, ignorando as particularidades. Ao contrário, é preciso, quando se tratar da culinária nacional, buscar abarcar as mais diferentes culturas alimentares do país em toda sua complexidade. E é aí que reside um dos maiores desafios dos processos de patrimonialização.

Os processos de patrimonialização nascem da necessidade dos países de preservar partes de suas histórias em risco de serem destruídas. A noção de patrimônio, explica Cecília Londres (2004) nasce no fim do século XVIII, durante a Revolução Francesa. A ideia de que os palácios e igrejas eram registros do processo de formação da nação e, portanto, tinham valor histórico foi utilizada para que os revolucionários não destruíssem os prédios que lembravam seus opressores.

Assim, pode-se afirmar que é o risco de se perder algo que se considera valioso que instiga o início do movimento de patrimonialização. Esse valor, em geral, tem ligação com a memória coletiva da nação. São considerados patrimônios aqueles lugares de memória apresentados por Nora (1993) que corroborem na construção da noção de unidade nacional.

Apesar da noção de patrimônio ter sua gênese ainda no século XVIII, e da ideia de os países preservarem seu patrimônio cultural ser debatida desde o início do século $\mathrm{XX}^{6}$, é apenas

\footnotetext{
${ }^{6} \mathrm{Na}$ Carta de Atenas, da Sociedade das Nações, de outubro de 1931, discute-se a necessidade de se preservar monumentos históricos.
} 
na segunda metade do último século que ela se torna preocupação mundial e vira compromisso de diversos países. Em novembro de 1972, em Paris, durante a Conferência da Organização das Nações Unidas para a Educação, a Ciência e a Cultura (UNESCO), foi assinada a Convenção para a Proteção do Patrimônio Mundial, Cultural e Natural.

$\mathrm{O}$ ato foi consequência de um movimento mundial que já vinha se desenrolando há algumas décadas, de preservação de monumentos, conjuntos e locais de interesse. Apesar de poder ser considerada um avanço, a Convenção tem como ponto fraco ainda focar em monumentos. Assim foi em toda a fase inicial desse processo de patrimonialização mundial, o que resulta em um perceptível privilégio da preservação da cultura identitária de grupos restritos.

A política de preservação que opta por apenas uma ideologia cultural e, por
exemplo, sistematicamente privilegia a restauração dos monumentos de elite
ou reforça a influência europeia na arte e arquitetura brasileiras não preserva
integralmente o patrimônio cultural de uma nação. É socialmente limitada e
pouco representativa. (FALCÃO, 1984, p. 45)

Neste sentido, retoma-se o conceito de que uma fala oficial nacionalista, necessariamente privilegia uma visão, como se todos no país fossem parte de um só grupo, ignorando as pluralidades e particularidades existentes no seio da nação (BHABHA, 2003). O mesmo vale para o processo de patrimonialização. Embora a escolha de patrimonializar parta da premissa de bens que tenham valor histórico para a nação, o que se percebe é que, em geral, segue-se a mesma lógica de privilegiar uma camada da população, diminuindo a representatividade de outra.

Como ressalta Canclini, os bens que ao longo da história foram reunidos por cada sociedade não pertencem a todos por mais que assim pareça. "Embora ocasionalmente o patrimônio sirva para unificar uma nação, as desigualdades em sua formação e apropriação exigem estudá-lo também como espaço de disputa material e simbólica entre os setores que a compõem" (CANCLINI, 2012, p. 72).

A questão é complexa, pois quando se define que um bem deve se tornar patrimônio, se faz uma seleção. Trata-se de um processo de escolha, que, portanto, envolve valores: por quê este e não aquele?

A atribuição de valor de patrimônio a um bem cultural pressupõe uma sedimentação de significados, algum grau de consenso quanto à atribuição dessa distinção - no sentido que Bourdieu atribui ao termo - e um interesse em 'preservar' esse bem, seja lá o que se entenda por isso. (LONDRES, 2004, p. 19) 
Ou seja, a depender de quem é responsável por esse processo, como ele é feito, a seleção se dará priorizando este ou aquele bem. "Assim, no campo da conservação do patrimônio, os valores vão ser sempre centrais para se decidir o que conservar - que bens materiais representarão a nós e ao nosso passado - bem como para determinar como conservar" (CASTRIOTA, 2011, p. 50). E, como ressalta o autor, a justificação das escolhas, há algumas décadas, do que conservar, do que era ou não patrimônio, eram feitas por um grupo relativamente fechado, de experts, detentores do poder-saber.

Com o decorrer das décadas, as discussões avançam no sentido de que o patrimônio cultural de um país vai muito além do que os prédios de pedra e cal. Como já foi abordado, o patrimônio é referencial da cultura e, consequentemente, da memória e da identidade das populações. Se é assim, ele não pode se restringir apenas a prédios, igrejas e palácios.

Patrimônio é tudo que criamos, valorizamos e queremos preservar: são os
monumentos e obras de arte, e também as festas, músicas e daç̧as, os
folguedos e as comidas, os saberes, fazeres e falares. Tudo enfim que
produzimos com as mãos, as ideias e a fantasia. (LONDRES, 2002 apud
LONDRES, 2004, p. 21)

No entanto, não se pode utilizar os mesmos parâmetros de avaliação para preservar construções, pinturas e saberes, comidas e festas. Nesse sentido, as críticas à forma de inventariar, às escolhas e às consequências da patrimonialização aumentam e têm seu auge no fim do século XX.

As inconsistências acumuladas levaram o comitê que toma as decisões a usar 'parâmetros mutantes' e, por fim, em 2005, a formar uma comissão de filósofos, antropólogos, sociólogos e semiólogos para discutir os conceitos de patrimônio mundial e obras de valor universal excepcional. [...] A pergunta mais pertinente não seria o que é patrimônio e sim quando há patrimônio. (CANCLINI, 2012, p. 70)

No Brasil, as discussões sobre a preservação do patrimônio cultural nacional ganham força com o Modernismo, principalmente com Mário de Andrade - que, em 1936, redigiria o anteprojeto de criação do futuro SPHAN - Serviço do Patrimônio Histórico e Artístico Nacional. Dá-se início ao processo de patrimonialização, com o foco principalmente nas artes - o Barroco é tido como um movimento legitimamente brasileiro. Trata-se de um primeiro passo, do reconhecimento do valor do patrimônio cultural do país. Todavia o processo de escolha do que merece ser preservado ainda era bastante vertical, de cima para baixo, e baseada em referenciais artísticos que, apesar da busca por uma autenticidade às matrizes nacionais, ainda se mostravam eurocêntricos.

As políticas, num primeiro momento, privilegiaram algumas narrativas para a proteção e tombamento dos bens culturais. Contudo, o texto do anteprojeto foi vanguardista no momento em que defendeu um olhar livre de estrangeirismos, 
dentro do próprio país, buscando compreender o Brasil, historicamente, por meio das manifestações populares de sua gente.

Reconhecer os bens pelo valor atribuído e não apenas pela monumentalidade é a principal característica que torna o texto de Mário de Andrade contemporâneo e à frente de seu tempo. Isso, porque, na década de 1930, ainda se reconhecia como patrimônio apenas as grandes edificações, por seus valores estéticos e artísticos que privilegiavam as referências europeias. (BRASIL, 2015e) ${ }^{7}$

A mudança de paradigmas, de que os valores culturais são criados pela sociedade e não pelo poder público, só se inicia com a Constituição Federal de 1988. Antes disso, afirmar nos órgãos de preservação que o patrimônio era, antes de qualquer coisa, um fato social causava escândalo (MENESES, 2012). Nesse contexto, o Artigo 216 da Constituição pode ser considerado como uma tentativa de democratizar o processo de patrimonialização, destacando o valor da memória dos diferentes que formam a sociedade brasileira. Além disso, já se vê uma preocupação em ir para além do tombamento de prédios e obras de arte:

Art. 216. Constituem patrimônio cultural brasileiro os bens de natureza material e imaterial, tomados individualmente ou em conjunto, portadores de referência à identidade, à ação, à memória dos diferentes grupos formadores da sociedade brasileira, nos quais se incluem:

I - as formas de expressão;

II - os modos de criar, fazer e viver;

III - as criações científicas, artísticas e tecnológicas;

IV - as obras, objetos, documentos, edificações e demais espaços destinados às manifestações artístico-culturais;

$\mathrm{V}$ - os conjuntos urbanos e sítios de valor histórico, paisagístico, artístico, arqueológico, paleontológico, ecológico e científico. (BRASIL, 1988)

Este texto é, portanto, um marco histórico. Ao reconhecer a necessidade de salvaguarda do patrimônio imaterial nacional, abre as portas para se pensar a cultura alimentar brasileira como elemento de tal patrimônio. Outro ponto importante a se destacar é que o texto constitucional, ainda no artigo 216, explicita a preocupação de que o poder público seja responsável pela preservação desses bens imateriais:

$\S 1^{\circ}$ O Poder Público, com a colaboração da comunidade, promoverá e protegerá o patrimônio cultural brasileiro, por meio de inventários, registros, vigilância, tombamento e desapropriação, e de outras formas de acautelamento e preservação. (BRASIL, 1988)

Observa-se ainda que a Constituição de 1988 já apontava os métodos de registro e inventariação para a preservação desses bens. Contudo, a salvaguarda desse patrimônio - e neles inclusos as tradições alimentares - é assegurada apenas em 2000, pelo Decreto $\mathrm{n}^{\circ} 3.551$, voltado ao Registro de Bens Culturais de Natureza Imaterial. O objetivo, como ressalta Ana

\footnotetext{
${ }^{7}$ Disponível em $<\underline{\text { http://portal.iphan.gov.br/noticias/detalhes/2735> }}$. Acesso em 27 fev. 2016.
} 
Elisabete Medeiros, é inserir o país no contexto mundial de valorização da diversidade como forma de desenvolvimento local.

Acredita-se que o retorno e institucionalização da dimensão intangível do patrimônio à cena política nacional resulta da necessidade de inserção internacional brasileira em um momento em que a cultura, em geral, e o patrimônio, em particular, revelam-se poderosos instrumentos a favor desta inserção via desenvolvimento local. (2004, p. 45)

A política pública prevista no texto constitucional enfim se efetiva, 12 anos depois. Para alguns especialistas o decreto vem tarde, uma vez que a discussão do valor do patrimônio cultural imaterial já era apresentada por Mário de Andrade no início do século anterior.

O Decreto 3551, de 4 de agosto de 2000, que institui o Registro de Bens Culturais de Natureza Imaterial [...] é ele uma manifestação tardia por parte do Estado em reconhecer o valor de nosso patrimônio cultural imaterial. Oito décadas o separam dos anseios dos modernistas preocupados com a valorização de nossa cultura. (LARAIA, 2004, p. 12)

No âmbito mundial, é apenas em 2003 que a UNESCO publica a Convenção para a Salvaguarda do Patrimônio Cultural Imaterial, ampliando o conceito de patrimônio para além de objetos ou construções concretas, abrangendo o saber-fazer, as celebrações, as formas de expressão e os lugares dos povos. Entre as motivações para a Convenção está, no próprio documento, o reconhecimento de que o processo de homogeneização resultante da globalização gera o risco de desaparecimento do patrimônio cultural dos povos, principalmente das comunidades tradicionais e indígenas, atores importantes na "produção, salvaguarda, manutenção e recriação" desse patrimônio, que garante a diversidade cultural humana (UNESCO, 2006, p. 3).

Nesse sentido, a qualificação de bens de natureza imaterial ou intangível pode ser vista como uma flexibilização de categorias de valoração do patrimônio (GONÇALVES, 2007). "Nesta concepção, a ênfase está nas relações sociais, ou mesmo nas relações simbólicas, mas não nos objetos e nas técnicas" (GONÇALVES, 2007, p. 114). Essa ampliação de definição do que é patrimônio abarca, assim, os simbolismos, os valores, as tradições, as memórias, a identidade das populações.

O grande questionamento que se faz com o advento do registro é como preservar manifestações culturais sem torná-las rígidas e, assim, fazer com que percam sua capacidade de se atualizar e, consequentemente, continuar existindo.

[...] muito mais do que no passado, que o fim último da conservação não vai ser a manutenção dos bens materiais por si mesmos, mas muito mais a manutenção (e a promoção) dos valores incorporados pelo patrimônio, sendo as intervenções ou tratamentos físicos aplicados a esses bens apenas um entre muitos meios para se obter este fim. (CASTRIOTA, 2011, p. 56). 
Nesse contexto, o manual de aplicação do Inventário Nacional de Referências Culturais (INRC), publicado em 2000, apresenta algumas das dificuldades que se encontra no processo de inventariação. O documento propõe um conjunto de práticas que possibilitem reunir o máximo de informações possíveis acerca do bem, naquele momento específico, ressaltando que se trata de um patrimônio que está em movimento continuamente:

1. Inventário é por definição rol completo: não falta nada do que se pode ou deve incluir; uma primeira característica de qualquer inventário é a exaustividade;

2. Para ser exaustivo, um inventário deve ser sistemático, ou seja, coerente com determinados critérios de inclusão e exclusão dos elementos que deverão constituí-lo. [...]

3. Inventariar, como lembra ainda a definição de dicionário, significa também encontrar, tornar conhecido, identificar. Portanto, descrever de forma acurada cada bem considerado, de modo a permitir a sua adequada classificação, é aqui tarefa primordial. [...]

Entretanto, esse conjunto, sendo delimitável num determinado espaço e tempo em função dos critérios definidos, sofrerá transformações: novos padrões emergirão, alguns entrarão em declínio e outros ganharão destaque imprevisto. Consequentemente, o INRC produzirá sempre como resultado um conjunto aberto de ocorrências, que ademais serão datadas e parciais, perante o conjunto de casos possivelmente observáveis. (BRASIL, 2000a, p. 28)

E por que então inventariar bens que não são estáveis, que não podem ser congelados ou isso os extinguiria? Com essa ampliação da concepção de patrimônio, abarca-se mais culturas, dando representatividade a populações que antes não eram tocadas pela patrimonialização. Percebe um movimento de democratização dos inventariados através do reconhecimento do patrimônio imaterial nacional - que desempenha um papel importante na construção da identidade das populações. "O patrimônio imaterial não é apenas um paliativo, um substituto do construído. É uma poderosa forma de mostrar e de afirmar a existência de grupos, especialmente daqueles que estão em uma situação minoritária” (TOURGEON, 2014, p. 73). Nesse sentido,

[...] esta mudança de estatuto é essencial, pois faz passar o patrimônio imaterial de agente passivo para agente ativo na construção social e cultural. Há muito considerado 'pequeno patrimônio' do povo, ele esteve associado às tradições folclóricas e deixado por sua conta para garantir a sua reprodução e sua sobrevivência. [...] foi muitas vezes tratado como coisa em via de desaparecimento, conservado a título de simples testemunho de um passado, para se ver e contemplar na posteridade. [...] Ele agora é visto como um meio eficaz de luta contra a globalização, para o desenvolvimento de um sentimento de pertença, apoio à criatividade humana e revitalização dos grupos socioculturais. (TOURGEON, 2014, pp. 68-69)

É nesse contexto de valorização da cultura de populações minoritárias, de democratização dos inventários, que se encaixa o processo de salvaguarda do Patrimônio 
Alimentar Brasileiro. Nessa mesma busca pela preservação das memórias coletivas que correm o risco de se perder, entram as tradições culinárias nacionais. "O lugar da identidade no âmbito do patrimônio chancelado pelo Estado é também um lugar escolhido e identificado. Há uma espécie de atestação no reconhecimento, uma diplomação que certamente legitima e expõe a categoria 'comida e povo' ou 'comida é povo"' (LODY, 2008, p. 407). Daí a opção deste trabalho de analisar o processo de inventariação do IPHAN, um órgão do Estado, e compará-lo com os inventariados do INPI, uma autarquia estatal que atua em parceria com uma entidade privada (SEBRAE), e do Slow Food, uma organização sem fins lucrativos.

No entanto, como já foi dito, registrar e salvaguardar esse patrimônio alimentar é complexo, uma vez que não estamos tratando de um bem estático. A cultura culinária de uma população é resultado de um contexto, de um território, de diversos elementos que dão significados àquela comida.

Os números refletem essa dificuldade. Depois de 14 anos da Convenção para a Salvaguarda do Patrimônio Imaterial, o IPHAN tem, no campo do Patrimônio Alimentar Brasileiro três saberes-fazer inventariados ${ }^{8}$, além de outros três em processo de registro ${ }^{9} . \mathrm{O}$ processo de salvaguarda é lento, pois exige, como já foi dito, um exaustivo levantamento de dados. Por outro lado, o que se percebe é um desaparecimento acelerado de tradições alimentares (BRASIL, 2015b). Como então garantir que esse bem imaterial não se perca antes mesmo de ser salvaguardado?

Esse movimento [de ampliação da noção de patrimônio cultural], se tem um
caráter inclusivo altamente positivo, na medida em que viabiliza o
reconhecimento das diferentes contribuições - dos grupos indígenas e afro-
brasileiros, dos imigrantes, entre outros - à constituição do patrimônio cultural
da nação, por outro lado traz problemas à prática de preservação, para cuja
solução nem as ciências sociais, nem as ciências jurídicas, têm respostas
prontas a dar. (LONDRES, 2004, p. 20)

Assim, Londres propõe que as políticas de patrimônio cultural só conseguirão enfrentar tal desafio se abrirem-se a outras perspectivas, a articulações com outras políticas públicas, "como as de meio-ambiente, ciência e tecnologia, direitos humanos, educação, comércio e turismo" (2004, p. 21). Como já ressaltado pelo historiador da alimentação, Loïc Bienassis, é preciso ir além do inventário como fonte documental. Para que se impeça verdadeiramente o “desaparecimento progressivo” do patrimônio cultural é necessário que ações específicas deem

\footnotetext{
${ }^{8}$ São eles: Modo Artesanal de Fazer Queijo de Minas, Ofício das Baianas de Acarajé e Produção Tradicional e Práticas Socioculturais Associadas à Cajuína no Piauí.

${ }^{9}$ São eles: Modo de Saber Fazer do Queijo Artesanal Serrano de Santa Catarina e Rio Grande do Sul, Ofício de Tacacazeira na Região Norte e Produção de Doces Tradicionais Pelotenses - RS Disponível em: http://portal.iphan.gov.br/pagina/detalhes/426 - consultado em 17 de fevereiro de 2016.
} 
sequência ao trabalho de salvaguarda. (BIENASSIS, 2011). Não basta apenas catalogar. O inventário é mais do que uma lista, deve ser um conjunto de medidas de preservação do bem imaterial.

Um dos caminhos que se aponta então para uma verdadeira democratização dos inventários do patrimônio alimentar nacional está na valorização das populações às quais pertence esse patrimônio. "Faz-se a identidade pelo que se come, como se come e que relação há entre a comida e os múltiplos papeis sociais dos indivíduos” (LODY, 2008, p. 420).

O Decreto 3551/2000, que estabelece o registro dos bens do patrimônio cultural imaterial do Brasil, prevê outras ações, para além da lista, que assegurem a salvaguarda. A Política Nacional de Desenvolvimento Sustentável dos Povos e Comunidades Tradicionais (Decreto $\mathrm{n}^{\mathrm{o}} 6.040$, de 7 de fevereiro de 2007) ${ }^{10}$ pode ser considerada uma dessas ações. Ela tem por objetivo promover o desenvolvimento sustentável dessas populações, “com ênfase no reconhecimento, fortalecimento e garantia dos seus direitos territoriais, sociais, ambientais, econômicos e culturais, com respeito e valorização à sua identidade, suas formas de organização e suas instituições" (BRASIL, 2007).

Dessa forma, busca-se ferramentas que possibilitem o empoderamento dessas populações, guardiãs de boa parte da tradição alimentar nacional, que, como aponta o documento de referência da $5^{\text {a }}$ Conferência Nacional de Segurança Alimentar e Nutricional, está em risco:

Observa-se que, apesar de, em algumas regiões brasileiras, tradições culturais
e alimentares estarem sendo descaracterizadas, com a perda da identidade
cultural alimentar, diversas outras regiões ainda resistem às mudanças,
preservando suas características em relação ao consumo de alimentos
tradicionais. São exemplos a farinha de mandioca, peixe fresco e açaí, que
predominam na Região Norte, e o arroz, feijão, carne bovina e leite mais
consumidos na Região Centro-Oeste. O mesmo se observa em relação a
determinados grupos da população, como povos tradicionais, povos
religiosos, pessoas com necessidades especiais e/ou com dieta diferenciada,
como os vegetarianos. [...] O desafio, portanto, é fortalecer e resgatar hábitos
alimentares tradicionais e saudáveis e a dimensão simbólico-cultural de nossa
alimentação (BRASIL, 2015b, p. 10).

Uma vez que um dos objetivos da patrimonialização é a inserção dos povos que foram sendo excluídos ao longo do tempo, esse poderia parecer um caminho óbvio, mas não é simples. Atualmente, boa parte dos povos tradicionais do Brasil, mesmo com essas políticas, enfrentam disputas por território e vivem em situação de insegurança alimentar e nutricional, ou seja,

\footnotetext{
${ }^{10}$ Por povos tradicionais, se entende, de acordo com o inciso I, Art $3^{\circ}$ : "grupos culturalmente diferenciados e que se reconhecem como tais, que possuem formas próprias de organização social, que ocupam e usam territórios e recursos naturais como condição para sua reprodução cultural, social, religiosa, ancestral e econômica, utilizando conhecimentos, inovações e práticas gerados e transmitidos pela tradição".
} 
passam fome e não têm condições de plantar os alimentos de sua tradição. De acordo com o Ministério do Desenvolvimento Social (MDS), 55,6\% dos adultos quilombolas estão em situação de insegurança alimentar no Brasil, e o percentual é de 41,1\% quando se trata das crianças e dos adolescentes dessas comunidades (BRASIL, 2014a, p. 44).

Além disso, outra questão que atinge essas populações é a disputa por terras. Trata-se de um complicador, afinal o direito ao território é o que pode garantir a soberania alimentar de um povo (ou seja, o direito não apenas de ter os nutrientes suficientes, mas poder consumir os alimentos da sua tradição, noção que o conceito brasileiro de segurança alimentar e nutricional abrange):

Assegurar a alimentação adequada e saudável não se restringe à garantia da
disponibilidade de nutrientes ou mesmo de alimentos. A prática alimentar,
enquanto expressão de identidade cultural e social, requer uma compreensão
mais ampla sobre como o alimento é produzido, transformado e
comercializado e também sobre as dimensões imateriais da alimentação as
quais dão sentido e historicidade às escolhas e práticas alimentares (BRASIL,
2015b, p. 32).

De acordo com dados do Instituto Nacional de Colonização e Reforma Agrária (INCRA), até setembro de 2015 já haviam sido titulados no Brasil cerca de 1.033.462 hectares, para 15.171 famílias, “com a emissão de 189 títulos para 142 Territórios Quilombolas, beneficiando 233 comunidades. Em relação à certificação realizada pela Fundação Cultural Palmares, 2.607 comunidades quilombolas espalhadas pelo território nacional já foram certificadas" (BRASIL, 2015a, p. 19).

Um criterioso mapeamento dos povos e comunidades tradicionais também se configura como elemento central para que seja possível a focalização de políticas públicas que considerem suas especificidades socioculturais e territoriais. O CadÚnico tem sido uma ferramenta importante nesse processo. Em 2011 eram apenas 173.726 famílias pertencentes a povos e comunidades tradicionais identificadas no Cadastro. Atualmente há 529.776, um aumento de 205\% (BRASIL, 2015a, p. 20).

O processo de inventariação do Patrimônio Alimentar Brasileiro se mostra, portanto, mais complexo do que uma simples catalogação. Logo, para que se alcance uma verdadeira democratização e se possa enfim falar em um documento que represente a cultura nacional é preciso olhar para as populações tradicionais e empoderá-las.

A noção de 'desenvolvimento cultural' tem significado para a UNESCO, desde então [1969-1970], que o 'projeto desenvolvimentista' não deve apenas relacionar-se harmoniosamente com a 'cultura' mas deve, antes, encontrar nela as suas próprias raízes. Daí o porquê da necessidade de se conceber 'políticas culturais' capazes de influenciar e dar suporte ao desenvolvimento econômico e social. (MEDEIROS, 2004, p. 46) 
Não se trata de tentar preservar práticas alimentares estagnadas no tempo, mas permitir que o saber-fazer desses grupos, e assim o Patrimônio Cultural Brasileiro, possa continuar a ser construído. Ao assegurar a essas populações território e Segurança Alimentar e Nutricional (e com ela Soberania Alimentar), a tradição alimentar nacional pode ser ressignificada, isto é, revivida pelos grupos e reatualizada. Nesse sentido, a preservação do Patrimônio Alimentar Brasileiro passa por uma efetiva interlocução entre os povos tradicionais, os especialistas de diversas áreas e o aparato institucional das políticas públicas. Ao final, o enraizamento dos povos tradicionais é a garantia da diversidade da cultura nacional.

Nessa perspectiva, os inventários desse patrimônio, uma vez que venham com ações de estímulo à perpetuação da cultura local, aliados ao fomento do turismo, apresentam-se com uma ferramenta capaz de tornar possível tal empoderamento das populações tradicionais. Como ressaltou Denísia Borba, o tombamento do patrimônio imaterial "certamente não garante que ele mantenha o culto da forma como é feita atualmente. Mas garante a liberdade de escolha do próprio destino pelo grupo. E essa liberdade, conferida à comunidade, deve ser entendida como o verdadeiro patrimônio cultural" (2004, p. 220). Tal empoderamento é essencial para que o processo de patrimonialização, ao trazer o mundo para a cultura local, não a destrua.

Com a Convenção da UNESCO, outro fator entra em cena: a globalização do patrimônio nacional. O geógrafo Everaldo Costa propõe o conceito de patrimonialização global, que define como

[...] o brusco movimento universal de espetacularização e banalização pela cenarização progressiva dos lugares promovida pela dialética Estado-mercado sobre a base das técnicas, da ciência e da informação; em síntese, é um processo de ressignificação dos lugares da cultura e da natureza em escala planetária $(2015$, p. 35).

Para Costa, "o processo de patrimonialização global é representante da transformação da própria história dos lugares em história mundial" (2015, p. 36). Dessa forma, ele defende que, assim como a globalização impacta identidade cultural, na fragmentação característica da modernidade tardia (HALL, 2003),

[...] no mesmo sentido, a patrimonialização global tratada hibridiza ou recria as identidades territoriais. [...] A patrimonialização global desponta, nesse sentido, como mecanismo socioeconômico e cultural moderno de transformação dos territórios de identidade, de ressignificação dos lugares da memória, dentro de distintas ideologias e, notoriamente, em nome do capital (COSTA, 2015, p. 38).

Uma das consequências do processo de patrimonialização que se nota, é exatamente a transformação dos locais a serem preservados em atrativos turísticos e com isso outros desdobramentos como a perda das características originais, que fizeram aquele local ser 
tombado em primeiro lugar, para adaptação às necessidades do mercado, e uma valorização imobiliária que acaba por excluir o morador autóctone, sujeito desse patrimônio, da área de conservação.

A noção de dialética da construção destrutiva na consagração do patrimônio
da humanidade diz respeito à contradição imperante entre a 'preservação' e a
mercantilização, a busca da democratização e da 'elitização' do patrimônio
urbano, de forma ampla, e das atrações turísticas, particularmente. [...] É um
processo de construção e desconstrução que se operacionaliza
simultaneamente - circunscrito por um movimento ininterrupto só entendido
na relação entre a particularidade e universalidade das destinações turísticas -
na consagração dos bens naturais e culturais do mundo. (COSTA, 2015, p. 47)

Retorna-se, assim, à questão da busca pelo conforto do turista no local de destino: apesar de ter saído de casa para "conhecer" novos locais, o turista não quer sair demais de sua zona de conforto, exige-se assim uma repetição de padrões de hospedagem, de gastronomia, suprimindo os diferenciais locais. A crítica de Costa é de que "[a] mundialização dos valores e das referências ocidentais sobre as práticas patrimoniais difundidas pelos aparatos globalizantes culminou na Convenção Relativa à Proteção do Patrimônio Mundial Cultural e Natural, adotada em 1972” (2015, p. 143). Assim, para ele, é impossível conceber o Patrimônio Mundial apoiado apenas na perspectiva de um valor que se pretende ser universalmente excepcional.

Nosso esforço é o de apontar a necessidade de uma visão dialética universalparticular que envolve os bens culturais do mundo, considerando que é na relação entre a construção global do patrimônio - que se dá através dos mecanismos da patrimonialização global - e a transformação local das cidades-patrimônio, que podemos desvendar a essência lógica que as transforma material e simbolicamente. (COSTA, 2015, p. 155 - nota 21)

Ou seja, o desafio passa a ser como valorizar o patrimônio cultural nacional sem homogeneizá-lo, sem destruir exatamente o que o torna único: a cultura que está em volta, na base do monumento ou local.

Os indivíduos modernos nascem e vivem dentro de culturas e tradições particulares, como seus antepassados de todas as épocas e áreas geográficas. Mas, de um modo inédito, estão expostos, são afetados e vivenciam sistemas de valores diferenciados e heterogêneos. Existe uma modalidade material e simbólica sem precedentes em sua escala e extensão. (VELHO, 1994, p. 39)

Ou como colocou Falcão, utilizando uma expressão de Aloísio Magalhães, o desafio é “desenhar uma política patrimonial para uma cultura que deve ser somatória, e não eliminatória" (1984, p. 45). Dessa forma, busca-se a democratização:

Não se pode enfrentar este desafio, sem a permanente e progressiva ampliação da participação das populações na salvaguarda do patrimônio cultural. Sem a permanente e progressiva ampliação da participação social no processo de tomadas de decisões e de implantação de programas e projetos oficiais. [...] A 
prática da preservação patrimonial deve contribuir para a prática da democracia. (FALCÃO, 1984, p. 45)

O que se percebe até aqui é que a perspectiva de um inventário do patrimônio alimentar nacional tem o potencial para uma inclusão democrática das populações mais desfavorecidas. Ao mesmo tempo, apenas a inventariação não pode ser a única solução, é preciso mais.

Sem dúvida, o turismo cultural tem importante foco na comida, além do monumento, do museu, do ideal nostálgico do que é antigo e/ou histórico. Contudo, novamente a comida é o 'registro sensível' mais direto na compreensão ecológica e cultural de um lugar, certamente uma 'conduta alimentária' enquanto forma e emoção de experimentar e viver pela boca a plenitude do território. (LODY, 2008, p. 414)

Outro fator que deve ser levado em conta é o efeito negativo que a patrimonialização pode ter, de elitização da culinária: os produtos tradicionais passam a ser gourmet, passa-se de tratar por gastronomia o que antes era culinária, ressalta o sociólogo Jean-Pierre Poulain.

A patrimonialização do alimentar e do gastronômico emerge num contexto de
transformação das práticas alimentares vividas no modo da degradação e mais
amplamente no do risco de perda da identidade. A história da alimentação
mostrou que cada vez que identidades locais são postas em perigo, a cozinha
e as maneiras à mesa são os lugares privilegiados de resistência. [...] Mas a
tendência mais surpreendente é o movimento transocial que coloca como
patrimônio comum práticas oriundas de espaços sociais populares, burgueses
e aristocráticos [...] Aos mesmo tempo, as culturas alimentares locais são
rotuladas de 'gastronomia' e fala-se agora de patrimônios gastronômicos
regionais. (POULAIN, 2013, p. 35 )

Um exemplo desse fenômeno é o que ocorreu com o açaí no Brasil. O fruto, que faz parte da tradição alimentar amazônica, passou a ser divulgado por todo o país. Virou moda, gourmet. Não é difícil achar um ponto de venda do suco da fruta em qualquer cidade média do Sul, Sudeste ou Centro-Oeste - ou até mesmo fora do país, como demonstram as figuras 1 e 2 . $\mathrm{Na}$ tradição do Norte, se toma ou açaí puro com peixe, ou com farinha e açúcar. No restante do país, entretanto, o sabor forte não caiu no gosto popular. O que se encontra nas lanchonetes é uma mistura do suco mais ralo, com guaraná, banana e granola. Completamente fora dos costumes amazônicos. Os restaurantes de alta gastronomia também se utilizam da fruta como matéria prima para os mais diversos preparos. E qual é o problema disso? São dois. O primeiro é que a popularização do fruto no resto do país fez com que ele ficasse inviável para a população amazônica, como aponta em entrevista ao sociólogo Carlos Alberto Dória, a ativista da cultura alimentar, Tainá Marajoara:

Veja, o açaí é o sangue da floresta na cosmovisão, de vários povos. Ele é o alimento que supre todas as necessidades, que traz a vida. E o açaí do Pará se diferencia do resto do Brasil porque está na foz do Amazonas, onde desemboca tudo o que o rio traz, e ele passa a ser um dos melhores açaís, de 
sabor mais peculiar. A crescente demanda pelo açaí, especialmente para exportação, passou a interferir diretamente na economia local. $\mathrm{O}$ açaí virou commodity. Antes havia uma expressão engraçada: uma pessoa grossa era um 'açaí de três' ('Fulano é grosso igual açaí de três') porque é aquele açaí grosso, que custava três reais. Hoje para tomar um litro de açaí grosso, tenho que pagar 25 reais! E o mesmo açaí que tem toda essa importância na cultura alimentar ancestral e cultura alimentar contemporânea está deixando a mesa do paraense, substituído por produtos industrializados, por arroz.... Hoje você tem monocultura de 200 mil pés de açaí, dez mil pés de açaí. ${ }^{11}$

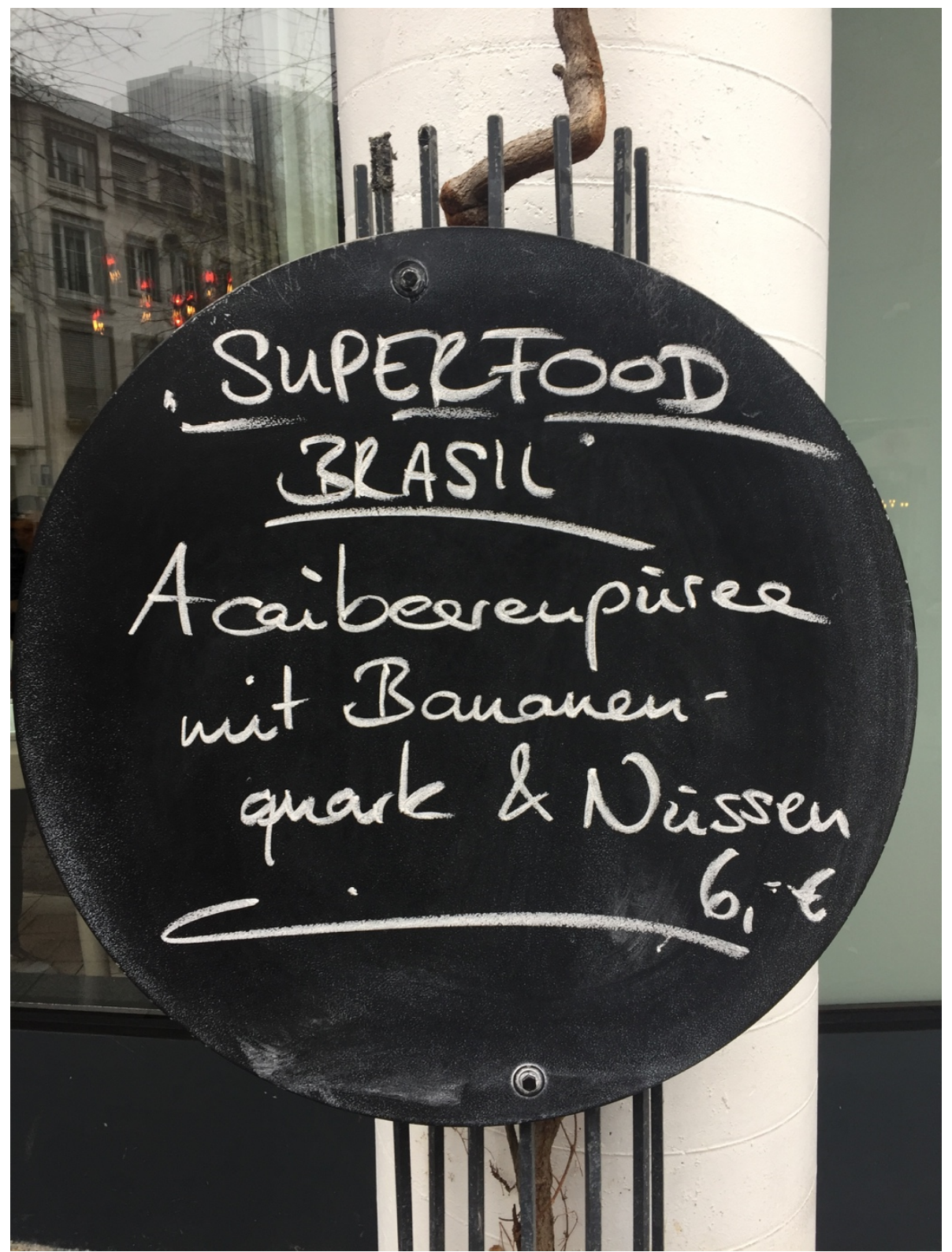

Figura 1. Anúncio de Açaí em Frankfurt, Alemanha, em novembro de 2016. 'Super alimento do Brasil': purê de açaí com bananas, iogurte e nozes. Foto da autora.

${ }^{11}$ Entrevista "Uma garota do barulho quer roubar a cena da gastronomia", publicada em 17 de março de 2015. Disponível em: http://ebocalivre.blogspot.com.br/2015/03/uma-garota-do-barulho-quer-roubar-cena.html. Consultado em 8 de novembro de 2015. 


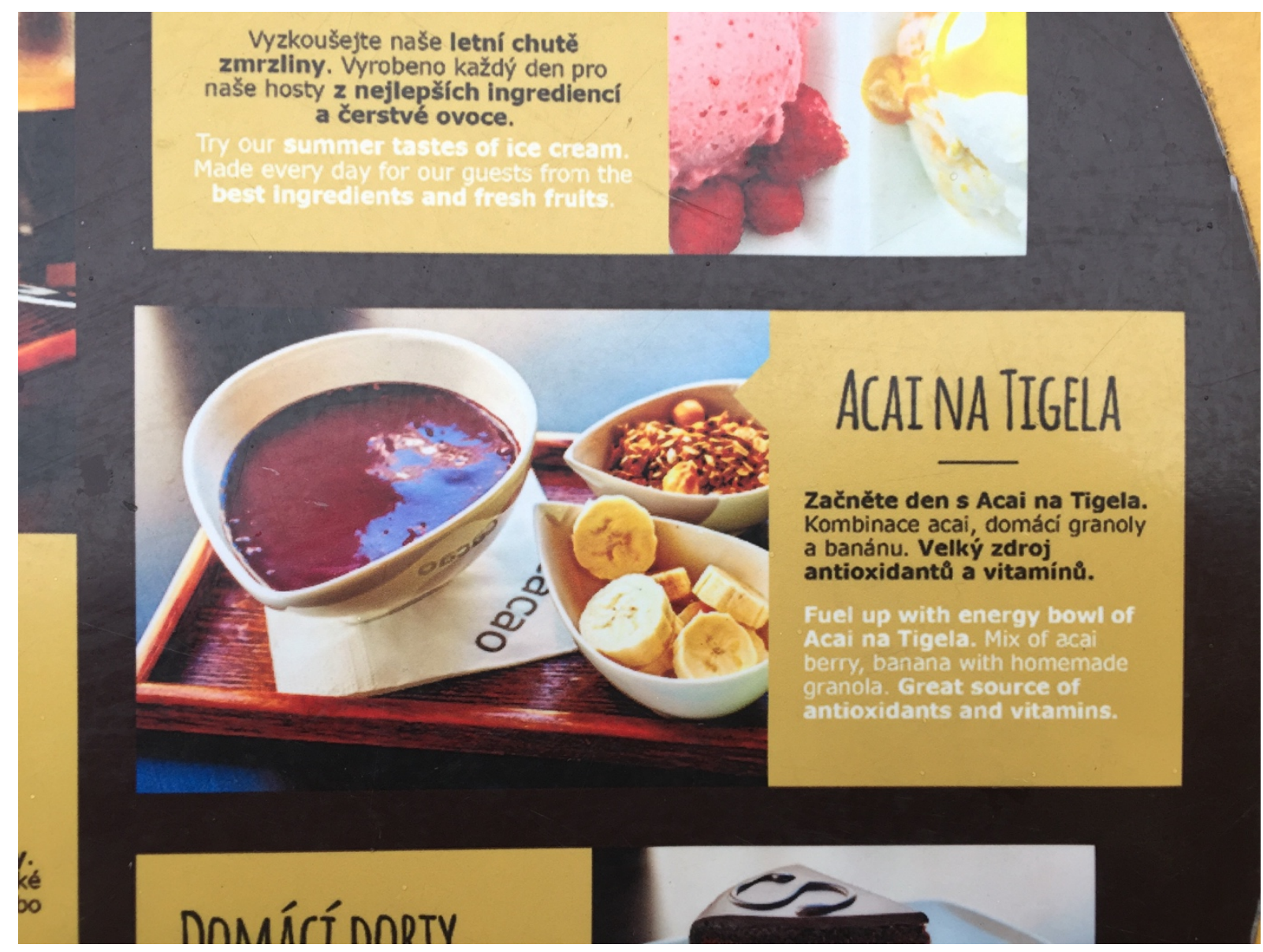

Figura 2. Açaí na Tigela em Praga, República Tcheca - novembro de 2016. "Abasteça-se com uma tigela de energia. Mistura de açaí, banana com granola caseira. Excelente fonte de antioxidantes e vitaminas." Foto da autora.

O segundo, é uma discussão muito mais complexa, de deslocamento do elemento de sua cultura. Por exemplo, quando alguém vai até certa comunidade e aprende as técnicas de feitura de um produto alimentar local. De volta, produz e comercializa esse bem imaterial. Ou simplesmente utiliza-o em outros preparos, também com fins comerciais. Como fica a comunidade?

Dessa forma, em termos patrimoniais, as comunidades têm dificuldades para reivindicar os benefícios referentes à comercialização de suas expressões culturais, uma vez que, na maioria dos casos, não há indicação de origem. De outra forma, em relação aos direitos morais há uma preocupação com o prejuízo cultural, social e psicológico causado pela utilização não autorizada. (BELAS, 2004, p. 195)

As questões dos direitos autorais devem ser refletidas em qualquer inventário que vise uma valoração econômica. O exemplo acima é baseado na discussão levantada pela ativista Tainá Marajoara, de que os chefs de cozinha, ao deslocarem os produtos de seus contextos, utilizam-se de ingredientes apenas, e não de saberes - desvalorizando a cultura na qual aquele produto está inserido. É diante dessa situação que entra a importância dos inventários do patrimônio alimentar. Eles fazem a vez dos direitos autorais, afirmando aquela população ou 
localidade como os atores protagonistas da cultura do preparo ou ingrediente catalogado. As ações subsequentes à inventariação devem ser no sentido de garantir tal protagonismo a essas comunidades.

Outro problema bastante recorrente no processo de salvaguarda do patrimônio alimentar é aplicação de regras sanitárias pensadas para a indústria alimentícia às produções artesanais de alimentos tradicionais. Há exemplos de distorções por todo o país, mas dois casos são enfáticos. O primeiro é o da carne de fumeiro na Bahia ${ }^{12}$ : "Comida de baiano iniciado, a carne de fumeiro - ou apenas o fumeiro, como se chama a carne defumada no moquém, é ingrediente proibido, integrante da lista de produtos tradicionais que não estão adequados às exigências legais. Resiste na ilegalidade, com produtores na pequena Maragogipe, incrustada no Recôncavo", narra a reportagem de Daniel Telles Marques, no jornal Estado de S. Paulo. O texto apresenta Simone, produtora que aprendeu o saber-fazer de destrinchar o porco, salgar e defumar lentamente com o pai. A técnica era utilizada para fazer a carne durar mais tempo numa época em que geladeira não era uma possibilidade. Hoje,

Presidente da Associação de Produtores de Carne de Fumeiro, organização que reúne os remanescentes da técnica de conservação e têmpera da carne de porco, o moquém, Simone é a porta voz de uma tradição em vias de extinção. Como os produtores ainda não conseguiram se adequar às exigências do Ministério da Agricultura e da Vigilância Sanitária para a produção das mantinhas, chouriças gordas e magras, linguiça de cabeça, entre outros defumados do focinho ao rabicó, a entidade que Simone representa é para a justiça algo como uma organização criminosa gastronômica. ${ }^{13}$

Com o aumento da rigidez das regras sanitárias para produção, poucos ainda insistem em fazer carne de fumeiro: apenas 14 produtores. "Fumeiro passou a ser vista como carne de gente pobre, porém é cara demais para os pobres (com a defumação, perde até $20 \%$ do peso original), sem competitividade no mercado. E de alguns anos para cá, ações do Ministério Público têm acuado os produtores por conta das condições sanitárias de preparo. 'Tratam a gente como bandido', diz Simone"14.

O Ministério Público ajuizou uma ação para fechar essas esparsas unidades de produção alegando que os locais são inadequados para o abate e beneficiamento. Como resposta, os produtores apresentaram um projeto para a construção de um prédio para o armazenamento da carne in natura e o preparo do fumeiro. Ele terá, como exigem as regras da vigilância sanitária

\footnotetext{
${ }^{12}$ Reportagem "Cortina de fumaça: a produção de carne de fumeiro no Recôncavo Baiano", publicada em 15 de abril de 2015. Disponível em: http://blogs.estadao.com.br/paladar/cortina-de-fumaca-a-producao-de-carne-defumeiro-no-reconcavo-baiano/. Acessado em 8 de novembro de 2015.

${ }^{13}$ Idem.

${ }^{14}$ Idem.
} 
brasileira (ANVISA), paredes azulejadas e mesas de aço inox, além de uma central única de defumação para todos os produtores. Ou seja, mesmo que cada um tenha seus segredos, terão que produzir o fumeiro juntos. A preocupação, aponta a matéria, é que isso acabe por uniformizar os produtos e eliminar as tradições familiares ${ }^{15}$.

O segundo exemplo é o de repressões e proibições em feiras, festas tradicionais e a pescadores em Santa Catarina. Os problemas recorrentes levaram algumas organizações não governamentais a apresentarem uma moção na V Conferência Estadual de Segurança Alimentar e Nutricional de Santa Catarina em defesa da cultura alimentar do estado ${ }^{16}$. O caso mais emblemático é o de São Miguel do Oeste:

Uma ação punitiva e desproporcional ocorreu na feira livre da cidade de São Miguel do Oeste em abril de 2010, quando o Ministério Público interditou a feira livre municipal daquela cidade sem qualquer comunicado prévio à administração municipal. A feira tinha apoio da prefeitura e feirantes eram agricultores que vendiam seus produtos coloniais diretamente aos consumidores (queijo, salames, doces e conservas, ovos, etc.). Foi montada uma operação policial, semelhante às que visam prender quadrilhas de traficantes, com viaturas e policiais armados, que cercaram a feira e levaram os agricultores presos, na frente de seus clientes, como se fossem bandidos. As autoridades municipais e a cidade se mobilizaram e exigiram que os agricultores fossem soltos, mas manteve-se o impedimento da venda dos produtos na feira. Até hoje há feirantes que precisam tirar na delegacia autorização para poder viajar para fora da região. ${ }^{17}$

Além disso, o grupo denuncia que, no oeste catarinense, a vigilância sanitária tem imposto exigências que deveriam ser apenas para cozinhas industriais, como azulejos até o teto, equipamentos em inox e proibição de abate na comunidade, para a realização de encontros, eventos ou festas comunitárias. "Também vem proibindo as doações de bolos, cucas, frangos assados, porcos e outras comidas, historicamente feitas nas casas das famílias para serem leiloados para custear as despesas comunitárias" ${ }^{18}$.

Nessa perspectiva, a questão da democratização da patrimonialização, apesar dos esforços, continua em voga. Isso porque o que se percebe ainda é uma fragilidade da comunidade local, que ou é impedida de dar continuidade às suas tradições alimentares ou termina por ser "colonizada" com seu próprio patrimônio.

\footnotetext{
${ }^{15}$ Idem.

${ }^{16}$ Um documento de teor semelhante, mas abrangendo a questão em todo o território nacional foi apresentado por membros do Slow Food Brasil (e aprovado pela plenária) durante a $5^{\text {a }}$ Conferência Nacional de Segurança Alimentar e Nutricional, que ocorreu de 03 a 06 de novembro de 2015, em Brasília.

17 Moção publicada em http://www.slowfoodbrasil.com/textos/noticias-slow-food/1000-mocao-em-defesa-dacultura-alimentar-de-santa-catarina-contra-os-excessos-da-vigilancia-sanitaria-e-do-ministerio-publico. Acessado em 8 de novembro de 2015.

${ }^{18}$ Idem.
} 
Esses são alguns dos desafios do plano de salvaguarda que o Estado traz a si, em responsabilidade conjunta com a sociedade para empreender ações e principalmente compreender que a identidade fragmentada e híbrida faz as novas identidades globalizadas.

A busca do 'emblemático' com quase síntese da identidade concentrada dialoga e se dinamiza nos confrontos do que é global e local - a uniformidade e a diversidade, a indústria e a natureza, o mercado e o auto-abastecimento, a modernidade a tradição, e ainda tocando nos campos da modernidade tardia e dos impactos da fragmentação do território e assim no que é idealmente regional. (LODY, 2008, pp. 415-416)

A importância de um inventário do Patrimônio Alimentar Brasileiro como Política Pública reside nesse ponto. Ferramenta de Salvaguarda.

O determinismo histórico foi substituído pela formulação de cenários e por análises de risco.

No entanto, como explicar o crescente interesse pelo passado por parte de nossos contemporâneos? Nunca antes se teve tanto acesso aos materiais do passado - em arquivos, museus, centros históricos, e também via os meios de comunicação e no contato direto em viagens turísticas. Além disso, bens que referem ao passado assumem um valor crescente no universo das mercadorias. (LONDRES, 2004, p. 26)

Nessa perspectiva, o turismo, pode ser uma das formas de se garantir a continuidade de práticas culturais alimentares que estão se perdendo. É essa relação de turismo e gastronomia que discutiremos a seguir, e os caminhos possíveis que ela apresenta para a salvaguarda do Patrimônio Alimentar Brasileiro. 


\section{O TURISMO E A GASTRONOMIA NO MUNDO: POSSÍVEIS INTERLOCUÇÕES}

Discutimos até aqui a importância da culinária como parte da cultura, memória e identidade de uma população. Mais especificamente, como a modernidade teve grande influência na formação de uma noção de gastronomia brasileira. É importante recordar que, neste trabalho, estamos tratando de um período específico: a contemporaneidade, uma era que o sociólogo jamaicano Stuart Hall (2006) definiu como modernidade tardia, marcada pela extrema fragmentação da identidade e pela aceleração do tempo. As incertezas geradas por essa falta de unidade, aponta Pierre Nora (1993), faz com que o sujeito busque uma coerência em referências do passado. Nessa perspectiva, o movimento referenciado nas tradições ganha força no processo de construção de uma identidade cultural. Preparos, sabores e aromas surgem, assim, como lugares de memórias de grupos diversos, reafirmando que a gastronomia está extremamente ligada à cultura, memória e identidade coletiva.

É preciso ainda ressaltar, de nossa reflexão inicial, o discurso oficial de identidade nacional assumido desde fins do século XIX, do Brasil como "país do futuro" - que pode ter corroborado para que a ideologia de uma modernização necessária, em oposição ao antigo, à tradição, ganhasse força em alguns aspectos da vida social. Nesse contexto, observa-se que a gastronomia popular tradicional, de origem indígena, negra e pobre foi desvalorizada durante séculos em detrimento da "civilizada e chic" culinária francesa. Além disso, o processo de modernização do país trouxe outras mudanças no cotidiano da população, que acabaram por influenciar as tradições alimentares, como a delimitação do tempo de lazer, a inserção da mulher no mundo do trabalho, o processo de urbanização e a aceleração do ritmo de vida, que fez com que refeições rápidas, fast food, passassem a fazer parte do hábito alimentar ocidental.

Passamos, então, à discussão de outro fenômeno moderno: o turismo. Se a relação da população ocidental com a alimentação se modificou na modernidade, pode-se afirmar que o turismo é um fenômeno que se consolida nesse período. Como ressalta Krippendorf, não é que o homem não viajasse antes, “o ser humano não nasceu turista, mas com a curiosidade e um sentimento um tanto nostálgico quanto aos países longínquos, que gostaria de conhecer. Em todas as épocas, isso esteve entre suas necessidades básicas e imediatas” (2000, p. 14). Mas, com o processo de industrialização e a consequente organização do tempo e limitação do lazer, o fenômeno turístico se expandiu.

Ao ponto em que, em dezembro de 1948, a Assembleia Geral das Nações Unidas inclui o lazer em um dos artigos da Declaração Universal dos Direitos Humanos. Assim, fica definido: “Artigo 24. Todo ser humano tem direito a repouso e lazer, inclusive à limitação razoável das 
horas de trabalho e férias periódicas remuneradas" (UNESCO, 1998). O que se percebe é que o turismo se desenvolve numa velocidade e proporção superlativas. Dessa forma, sua faceta de atividade econômica passa a ser o foco principal, se impondo às outras dimensões deste fenômeno social.

O turismo é uma combinação complexa de inter-relacionamentos entre produção e serviços, em cuja composição integram-se uma base cultural, com herança histórica, a um meio ambiente diverso, cartografia natural, relações sociais de hospitalidade, troca de informações interculturais. O somatório desta dinâmica sociocultural gera um fenômeno, recheado de objetividade/subjetividade, consumido por milhões de pessoas, como síntese: o produto turístico (MOESCH, 2002, p. 10).

Essa simplificação econômica do fenômeno é recorrente e um dos principais pontos de crítica de pesquisadores da área: as políticas públicas na verdade são tratadas pelos órgãos governamentais como políticas de mercado e, dessa forma, acabam por ignorar a complexidade social que envolve o fenômeno turístico. "Considerado a fundo, o processo do turismo não é aquele do indivíduo que viaja, mas aquele da massificação do fenômeno em seu todo. $\mathrm{O}$ principal problema do turismo moderno está, na realidade, no volume - no grande volume" (KRIPPENDORF, 2000, p. 66).

Mais uma vez, vale ressaltar que uma das características predominantes desse período é a velocidade. Logo, o crescimento do fenômeno turístico é extremamente acelerado. Com a massificação, o turismo passa a ser uma atividade que causa desequilíbrios. Grandes populações passam a frequentar espaços naturais e cidades cuja estrutura não é capaz de atender a todos. A população local acaba sendo a que mais sofre: se a água e a energia elétrica não são suficientes para todos durante a alta temporada, corta-se o fornecimento dos locais e não das instalações turísticas. "Acontece muito a inversão das prioridades [...]. O turismo engole os terrenos, a natureza e o patrimônio cultural. Torna-se um novo colonizador e destrói o meio ambiente" (KRIPPENDORF, 2000, p. 150).

E não é apenas a "invasão" pelos turistas que desequilibra o meio ambiente nas regiões receptoras. A estrutura que o turismo exige, de hospedagem, atrações e restaurantes, acaba atraindo mão de obra de outras regiões do país e até mesmo estrangeira, principalmente sob a alegação de falta de capacitação da população local. Dessa forma, os empregos que são gerados na região, concentram-se em funções de baixa remuneração.

A invasão é perfeita: do exterior pelos turistas, e do interior pelos novos residentes e mão-de-obra estrangeira. Esse esquema é clássico e ocorre em todos os lugares de forma mais ou menos similar. E quer nos agrade ou não, é assim que o turista moderno denota traços colonialistas (KRIPPENDORF, 2000, p. 81). 
Além disso, há uma consequente valorização imobiliária das áreas centrais (ou próximas à praia) nessas regiões, que acaba por pressionar os habitantes locais para áreas mais afastadas, onde o custo de vida não se eleva tanto. Esse fenômeno é o que o geógrafo Everaldo Costa (2015) denomina de dialética da construção destrutiva - ao valorizar e patrimonializar os espaços históricos e torná-los turísticos, a população originária, é forçada para as regiões mais distantes do centro, levando consigo a cultura que tornou aquele local um atrativo em primeiro lugar.

Com isso, o patrimônio cultural alimentar também é atingido. A culinária local se transforma. Os ingredientes mudam ou encarecem, a população autóctone migra para a periferia, levando consigo os costumes alimentares. As regiões turísticas são dominadas por restaurantes com padrões internacionais: a comida local ganha nova roupagem, tornando-se mais refinada, e aumenta a disponibilidade de culinária francesa, italiana, americana, entre outras, como relatam Daniel Hiernaux-Nicolas, Carmen González-Gómez sobre esse processo de refuncionalização do centro de Querétaro, no México:

O fechamento progressivo das pequenas lojas e negócios tradicionais como sapateiro, o açougue do bairro, mas também o cabelereiro ou a cantina, implica no desaparecimento de múltiplos odores que formavam parte da paisagem olfativa do bairro. Uns odores desaparecem, outros pareciam surgir do nada: o odor penetrante do pequeno café com suas duas mesas na calçada; a doceria 'francesa' que substitui o odor das memelas, das gorditas e demais delícias da comida mexicana tradicional. O residente de sempre se encontra deslocado frente a esses odores que desconhece, não necessariamente aprecia e que não têm nada a ver com o odor de bebedeira da pulquería [local onde se vende pulque, bebida alcóolica típica mexicana], de óleo requentado dos pontos de tacos ou das velas da loja de artigos religiosos (2014, p. 11, tradução nossa).

Outro aspecto a ser destacado da "colonização" turística é o processo de homogeneização dos espaços. Nota-se uma tendência de se padronizarem hospedagem, entretenimento e até mesmo a alimentação, num movimento de internacionalização. Dessa forma, o turista pode "conhecer" um novo local, sem abrir mão dos confortos aos quais está habituado.

Assim, o poder dos novos residentes e visitantes toma posse do bairro. Odores, sons, cores, texturas, tudo forma um conjunto sinestésico que demole progressivamente a paisagem sinestésica do bairro, por pequenas investidas, uma multiplicidade de minúsculas intervenções que pouco a pouco se tornam dominantes e condicionam a aparição de uma nova paisagem sensorial e de novas experiências da vida urbana (HIERNAUX-NICOLAS; GONZÁLEZGÓMEZ, 2014, p. 12, tradução nossa).

Contraditoriamente, a valorização turística muitas vezes causou e ainda causa a desvalorização da cultura local. Percebe-se, mais uma vez, que, assim como no processo de 
formação da gastronomia brasileira, há uma hierarquização de culturas. Uma busca por homogeneização baseada em padrões europeus ou norte-americanos. A cultura popular local é avaliada como menor, como pouco civilizada e, assim, suplantada pelos costumes dos países "desenvolvidos".

Mas o que fez com que o turismo se deturpasse dessa forma? Para Krippendorf a explicação vai além do simples interesse econômico, é mais complexa que isso e inclui uma sociedade voltada para o lazer como forma de escape do cotidiano massacrante.

Nos nossos dias, a necessidade de viajar é sobretudo criada pela sociedade e marcada pelo cotidiano. As pessoas viajam porque não se sentem mais à vontade onde se encontram, seja nos locais de trabalho, seja onde moram. Sentem necessidade urgente de se desfazer temporariamente da rotina massificante do dia-a-dia do trabalho, da moradia e do lazer, a fim de estar em condições de retomá-la ao regressarem (KRIPPENDORF, 2000, pp. 14-15).

A viagem, nessa perspectiva, se tornou uma norma social (KRIPPENDORF, 2000), uma vez que o relaxamento não é mais possível no ambiente doméstico, as férias viram sinônimo de viagem. O modelo de um turismo industrial cria contradições e o sujeito viaja para locais cheios para descansar, em programações com agendas mais cronometradas do que no dia-a-dia, pois as férias têm de ser produtivas. No final das contas, o que o sujeito busca é um descanso do trabalho, apenas. O cotidiano se repete nas férias sob formas de outras atividades. "O turismo funciona como terapia da sociedade [...]. Ele exerce um efeito estabilizador não apenas sobre o indivíduo, mas também sobre toda a sociedade e a economia" (KRIPPENDORF, 2000, p. 16).

Para definir este processo, Ritzer (2006) usa o conceito de McDonaldização em que, não só a gastronomia, mas a própria sociedade está organizada de maneira altamente racionalizada. Fazendo uma analogia com o modo de funcionamento dos restaurantes McDonald's, se o aplicarmos ao visitante de uma cidade, este terá umas férias:

- altamente eficientes, em que, ajustadas ao tempo disponível, terá o máximo de experiências possíveis.

- altamente calculáveis, em que itinerários, lugares visitados e custos são conhecidos com anterioridade à viagem.

- altamente previsíveis, em que evitam contatos com âmbitos da cultura que não são familiares, com a consequente ausência de surpresas.

- altamente controladas/automatizadas, em que se revela uma preferência por tratar com pessoas cujo comportamento está altamente limitado por roteiros de atuação.

Perante estas consequências da organização social da sociedade pós-moderna, a cozinha de um lugar pode oferecer experiências vinculadas significativamente a espaços e territórios, revelando-se como uma das áreas de autenticidade que podem ser desfrutadas com relativa facilidade por turistas de qualquer procedência (CARRAL et al, 2016, p. 264).

Nessa linha de análise, o turismo talvez tenha de passar a ser compreendido como um fenômeno de sujeitos que se relacionam, que, na alteridade, se reconhecem no Outro. 
Atualmente, ressaltou Krippendorf, "na maioria dos casos, o encontro segue a lógica de um clichê, é artificial e enganador" (2000, p. 83). Assim, as viagens apenas servem para confirmação de clichês e preconceitos - tanto de autóctones para com turistas como o contrário. A viagem como experiência se perde, por que se perde, também, a ideia de autenticidade do local. Num processo semelhante ao que ocorre com a gastronomia local, onde

A relação entre identidade e tipicidade é muito forçada, pois a tipificação não retém a riqueza cultural na qual os pratos, um dia, estiveram imersos. Ao simplificar a relação da comida com a cultura em sentido amplo, dá-se uma caricaturização desta última, fazendo com que os próprios consumidores locais já não mais a reconheçam como autêntica (DÓRIA, 2014, p. 166).

Idealmente, "o turista, percorrendo outras regiões ou países, tem nessa vivência de semelhanças e diferenças uma das razões primeiras das suas práticas" (GASTAL; MOESCH, 2007, p. 36). Como então recuperar esse sentido de viagem?

\subsection{RETORNO AO LOCAL: PONTO DE ENCONTRO DE TURISMO E GASTRONOMIA}

Um dos conceitos que emergem como resposta à massificação e suas consequências é o da "sustentabilidade". A ideia de um "turismo sustentável" surge na década de 80, baseada no documento "Nosso Futuro Comum”, publicado em 1987 pela Comissão Mundial sobre Meio Ambiente e Desenvolvimento da ONU. "O Relatório Brundtland [...] estabeleceu as bases para promover o desenvolvimento sustentável, isto é, a integridade ecológica, a eficiência econômica e a igualdade social" (SILVEIRA, 2005, p. 225) ${ }^{19}$.

O segundo fator-chave [para a maior adesão ao discurso da sustentabilidade] é o crescimento tremendo da atividade turística nos últimos 20-30 anos. Esse crescimento tem estimulado duas linhas de interesse no espaço do turismo sustentável. Primeiro, a realidade de que ao contribuir com uma grande parte da atividade econômica na maioria dos países, a atividade turística contribui mais para o uso dos recursos naturais e os seus impactos no meio ambiente cresceram significantemente. Segundo, a ideia de que a atividade turística pode ser um caminho no qual países e regiões com rendas mais baixas podem melhorar seus padrões de vida. (UNWTO, 2016, p. 2)

Assim, o turismo sustentável emerge sob diferentes rótulos: turismo de aventura, turismo rural, turismo cultural, ecoturismo, turismo ambiental... "Esses diferentes tipos de turismo são considerados compatíveis com a conservação do meio ambiente, opostos ao turismo de massas, do tipo fordista" (SILVEIRA, 2005, p. 224). No entanto, o conceito de sustentabilidade vem sendo, desde então, bastante debatido. Apropriado por discursos políticos e por empresários, o ideal de "desenvolvimento sustentável" ainda não possui uma clara

\footnotetext{
${ }^{19}$ Todos os textos têm tradução nossa.
} 
definição e é, muitas vezes, reduzido ao seu aspecto de sustentabilidade ambiental - que não agrida o meio ambiente. Nessa perspectiva, pode-se falar em desenvolvimento sustentável, mesmo que o empreendimento contribua para a desigualdade social local, por exemplo. Retorna-se, dessa forma, ao mesmo problema anteriormente apresentado, de predominância dos aspectos econômicos em oposição a uma visão mais holística do fenômeno turístico. As ambiguidades e contradições acabam surgindo.

Desse ponto de vista, o conceito de desenvolvimento sustentável é útil na medida que aponte para o estabelecimento de um novo estilo de organização da economia, da sociedade e sua relação com a natureza buscando construir um modelo de desenvolvimento distinto ao do crescimento econômico tout court. Isto é, um modelo de desenvolvimento oposto ao curto prazo, que encontre sustento na conservação ambiental, na eficácia econômica e na igualdade social e que tenha seu fundamento em uma visão a longo prazo. (SILVEIRA, 2005, p. 226)

Essa discussão conceitual é complexa e não é nosso objetivo neste trabalho aprofundarmos nela. Entretanto, é importante trazê-la à tona pois esse é um dos pontos discursivos que une o turismo e a gastronomia e que, direta ou indiretamente, influenciará no desenvolvimento do turismo gastronômico nas décadas seguintes. De acordo com a Organização Mundial do Turismo, a sustentabilidade é um conceito multifacetado, que poderia, portanto, ser abordado por diferentes ângulos (UNWTO, 2016). Assim:

As diretrizes e práticas de administração do desenvolvimento do turismo sustentável são aplicáveis a todas as formas de turismo em todos os tipos de destinação, inclusive turismo de massa e os vários nichos de segmentos do turismo. Os princípios da sustentabilidade se referem aos aspectos ambiental, econômico e sociocultural do desenvolvimento do turismo e um equilíbrio adequado deve ser estabelecido entre essas três dimensões a fim de garantir sua sustentabilidade a longo prazo. (UNWTO, 2016, p. 2)

Trata-se, portanto, de uma definição bastante ampla, que pode abarcar qualquer tipo de produto turístico. Para autores como Rosário Scarpato, entretanto, as prioridades são outras para sustentar tal título. Dessa forma, o turismo seria considerado 'sustentável' quando: “ele reconhece a importância da comunidade receptora; ele adota boas práticas para o tratamento do pessoal; ele maximiza o retorno econômico para as comunidades locais; o seu desenvolvimento acontece em baixa velocidade; ele é amigável com o meio ambiente; turistas adotam um comportamento responsável" $(2002, \text { p. 138 })^{20}$. É interessante ressaltar aqui a participação do turista como parte integrante da sustentabilidade turística. Esse é um dos pontos que será recorrente em soluções a serem discutidas mais à frente.

\footnotetext{
${ }^{20}$ Todos os textos têm tradução nossa.
} 
O debate se prolonga até os dias de hoje e continua entre as principais preocupações dos atores internacionais do turismo. Tanto é que a ONU designou, em fim de 2015, que 2017 será o "Ano Internacional do Turismo Sustentável pelo Desenvolvimento". A ação pretende promover o papel do fenômeno nas Metas Mundiais de Desenvolvimento Sustentável. Para isso, incentivará a participação do turismo em cinco áreas chave: “crescimento econômico sustentável e inclusivo; inclusão social, emprego e redução da pobreza; eficiência de recursos, proteção ambiental e mudança climática; valores, diversidade e patrimônio cultural; entendimento mútuo, paz e segurança"21.

Assim como o turismo, a gastronomia também é afetada pela discussão da sustentabilidade. Afinal, o modelo de produção em massa e a industrialização alimentar têm consequências ambientais, sociais e econômicas. Dessa forma, o ideal de gastronomia sustentável, ou ecogastronomia também ganhou força nas últimas décadas.

Nesse sentido, gastronomia sustentável pode ser descrita também como ecogastronomia e interage com todos os outros componentes do sistema de desenvolvimento, como nós também vimos acima no caso do turismo sustentável. Visitantes temporários para uma comunidade, como turistas, devem ser considerados - e deveriam se considerar - como membros daquela comunidade. Num nível mais específico, gastronomia sustentável é sobre produzir comida que é sensível do ponto de vista ambiental, e prepará-la e comê-la de forma que nutra ambos corpo e mente. (SCARPATO, 2002, p. 139)

Turismo e gastronomia convergem, dessa maneira, em torno do discurso de um crescimento sustentável. Independentemente das contradições do conceito, nos interessam aqui as soluções apontadas na busca por novos modelos nesses dois campos.

Turismo oferece a oportunidade para produtores de alimento de agregar valor aos seus produtos criando uma experiência turística em torno das matérias primas [...]. Ao mesmo tempo, experiências gastronômicas podem agregar valor ao turismo ao prover o turista a ligação entre a cultura local, a paisagem e a comida, e ao criar a 'atmosfera' tão essencial para uma experiência memorável de férias. [...] tanto uma gastronomia sustentável quanto um turismo sustentável são necessários. Alguma integração entre essas duas perspectivas deve ser possível. (HJALAGER; RICHARDS, 2002, p. 224)

Há diversos segmentos turísticos que se apoiam nesse escopo de sustentabilidade: ecoturismo, turismo rural, de aventura, cultural, etc. Em vários deles é possível perceber a recorrência de rotas alimentares apresentadas como uma das soluções de integração dos campos de turismo e gastronomia. O que nos faz retomar outro ponto: o dos roteiros e guias turísticos. Essa relação entre gastronomia e turismo não vem de hoje, na verdade ela é bastante antiga.

${ }^{21}$ Disponível em http://www2.unwto.org/tourism4development2017. Consultado em 22 out. 2016. Tradução nossa. 
Durante o século XII, no início dos empreendimentos turísticos, na Europa, a alimentação aparecia apenas como uma necessidade deslocada - os viajantes, burgueses, pouco se interessavam pela culinária do destino, popular. Sua atenção era muito mais dirigida para a paisagem. Mas na segunda metade do século XVIII o olhar dos viajantes se modifica, influenciado por diversos fatores. "Doravante, os escritos de viagem cuidarão de reportar a diversidade e a especificidade dos locais, dos homens, também dos modos entre os quais figurarão os costumes alimentares locais" (CSERGO, 2006, p. 3, tradução nossa).

É nos anos de 1840 que surgem no continente europeu, com a expansão das estradas de ferro, os guias turísticos. A gastronomia começa a aparecer de forma mais sistemática com as especialidades alimentares locais, mas não faz parte ainda da economia turística. Isso ocorre apenas nos anos de 1920. “O viajante curioso de conhecer o Outro e outro local deverá buscar um desligamento de sua origem alimentar, experimentar a especialidade local apontada pelo guia, tão pitoresca quanto a paisagem à qual ela se associa” (CSERGO, 2006, pp. 4-6).

É também no início do século XX que os clubes automobilísticos começam a se organizar e a publicar os seus guias. E o mais famoso deles, o Guia Michelin, é lançado em agosto de 1900, na "alvorada de um novo século", com o objetivo de melhorar a mobilidade dos mais de três mil automóveis que rodavam pela França. Foram impressos e distribuídos gratuitamente cerca de 35 mil exemplares contendo informações práticas sobre reparo de pneus, postos de abastecimento, hotéis, restaurantes, mecânicos, mapas das cidades etc. Somente em 1926 nasce a estrela Michelin de "boa mesa". A classificação com duas ou três estrelas para um estabelecimento só surge em 1931 no interior do país e em 1933 em Paris. Já as definições uma estrela, uma mesa muito boa em sua categoria, duas estrelas, merece o desvio, e três estrelas, merece a viagem - são de $1936 .^{22}$

No Brasil, o guia francês chegou apenas em 2015. Mas em 1965, seguindo o mesmo modelo, nasceu o Guia 4 Rodas - que teve 50 anos de publicação e cujo fim foi anunciado em dois de junho de $2015^{23}$.

No início da década de 1960, três integrantes da revista QUATRO RODAS embarcaram em uma Kombi a fim de percorrer a Via Dutra entre São Paulo e o Rio de Janeiro. A bordo, estavam Mino Carta, chefe de redação, Victor Gouveia, redator-chefe, e Roberto Civita, diretor de publicidade. A ideia da expedição era mapear todos os pontos de parada - hotéis, postos de combustível, restaurantes... - ao longo do caminho. A aventura daria origem ao primeiro roteiro turístico da revista - e seria também o embrião do primeiro GUIA QUATRO RODAS, cuja primeira edição do Guia Brasil seria lançada

\footnotetext{
${ }^{22}$ Disponível em: < http://www.viamichelin.fr/tpl/mag6/art200903/htm/tour-saga-michelin.htm>. Acesso em: 04 ago. 2015.

${ }_{23}$ Disponível em: < http://grupoabril.com.br/pt/imprensa/releases/editora-abril-promove-mudanca-na-estruturaeditorial-e-reinventa-modelo-comercial> . Acesso em: 04 ago. 2015.
} 
em setembro de 1965. O projeto tinha como parâmetro o guia francês Michelin. ${ }^{24}$

Entretanto, o guia brasileiro sempre foi menos aprofundado do que o francês no que diz respeito às origens dos preparos, como argumenta o sociólogo Carlos Alberto Dória (2014) ao demonstrar a simplificação de se apresentar um prato único para cada região. O que não diminui sua importância no processo de consolidação de uma gastronomia "regional", ressalta Csergo.

[...] são eles [os guias turísticos] que, confinando de forma duradoura a particularidade culinária em representações estereotipadas, acabam por impôla - relacionando-a com a noção de ponto de interesse - como parte integrante do patrimônio, no mesmo nível do mirante, da arquitetura ou das personagens que, daí em diante, pontuam as paisagens e as histórias locais. (CSERGO, 1998, p. 817)

Trata-se, assim, de um momento de crescimento do movimento de regionalização na França e, com ele, a valoração da gastronomia como produto turístico cresce. Em 1890, Jean Charles-Brun redige, pelo Touring Club (clube automobilístico), um livro intitulado 'Turismo e Regionalismo'. Ele tinha o objetivo de mostrar que o turismo era terreno fértil para a ideologia regionalista e que poderia, assim, ser ferramenta bastante útil de desenvolvimento local (CSERGO, 2006). Esse discurso de valorização dos recursos gastronômicos locais também é perceptível no contexto da Exposição Universal de 1900, quando um grande banquete com as “especialidades francesas” é servido (CSERGO, 1998).

$\mathrm{Na}$ Itália, outro país referência do turismo gastronômico, em 1931 é lançado pelo Touring Club o Guida gastronomica d'Italia (CAPATTI, 2006). No entanto, é perceptível o estímulo da regionalização também por políticas de estado:

Em 1931, o fascismo encoraja o consumo de produtos nacionais, através de uma política alimentar denominada autarquia, e relança a visita das regiões italianas graças a uma rede ferroviária que permite viajar um pouco por todos os lados, assim como as primeiras estradas, criando, dessa forma, no norte, um novo tipo de mobilidade. (CAPATTI, 2006, p. 2)

Tratam, portanto, de políticas afirmativas de identidade nacional que se apoiam na cultura alimentar para construir um discurso oficial. Retomamos assim o conceito de Bhabha (2003) de que a identidade nacional existe muito mais como discurso do que no cotidiano, uma vez que a fala oficial nacionalista termina por ignorar as pluralidades e particularidades existentes no seio do país. Mesmo que os movimentos regionalistas tenham como objetivo exatamente valorizar as diferenças de cada local, há o desafio de, dentro dessas áreas não permitir a criação de estereótipos.

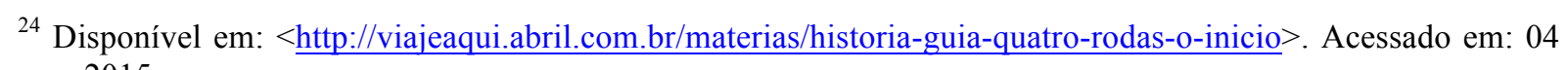
ago. 2015. 
Essa concepção da particularidade local imposta pelo ambiente domina a consciência das cozinhas e culturas regionais a partir da década revolucionária. Com efeito, no final do século XVIII, após a introdução dos produtos do Novo Mundo ter redesenhado, em parte, as culturas alimentares locais, a grande mudança não é a invenção das cozinhas regionais - elas existiam no âmbito de áreas certamente mal circunscritas - mas a atenção que lhes é dada, a consciência que se tem delas. [...] Assim, é quando a Revolução redefine a relação real e imaginária, as representações e os afetos que unem e opõem Paris à província, o nacional ao local, o universal ao particular, que as cozinhas e as especialidades alimentares regionais se libertam dos limites geográficos e sociais nos quais estavam mergulhadas, emergem como sinal distintivo da localidade e tornam-se um elemento notável da nação em sua diversidade e representações. (CSERGO, 1998, p. 809)

Percebe-se que se trata de um movimento de apropriação por parte das elites locais da cultura alimentar popular. Além disso, é uma construção do regionalismo, definindo - e assim restringindo - as áreas às quais pertencem cada cultura, como se houvessem fronteiras bem definidas. Dessa forma, pode-se afirmar que o turismo tem um papel preponderante na construção do discurso da gastronomia regional e do conceito de tipicidade.

A assimilação da paella como um prato 'tipicamente espanhol' é
contemporânea do franquismo e da abertura da Espanha ao turismo de massa;
a 'tomatização' das receitas 'à provençal' é contemporânea da revolução
Francesa (abertura em Paris do restaurante dos Frères provençais, muito
frequentado pelas elites) e do surgimento do regionalismo, a partir do modele
de Félibrige - o mesmo que inventou todas as peças de um dispositivo
pretensamente tradicional com as 'treze sobremesas de Natal'. Na França e
em tantos outros países as cozinhas regionais se constituem como tais não ao
longo dos tempos, mas no século XIX. (ORY, 2013, p. 24)

Há uma busca por receitas “ autênticas” e, em 1989, a rede hoteleira Logis de France, começa a organizar um concurso de cozinha regional e edita as melhores receitas. O movimento se difunde pela cadeia produtiva alimentar francesa. Um "novo turismo" se desenvolve.

Com efeito, numerosas são as estruturas institucionais ligadas ao turismo (comitês regionais ou departamentos de turismo, agências de turismo, sindicato de iniciativas, câmaras de comércio...) que comunicam e mobilizam os proprietários de restaurantes e os artesãos de negócios de alimentação em torno dessa temática. (POULAIN, 2013, p. 32)

Aliás, a hotelaria é outro elemento fundamental dessa relação simbiótica de turismo e gastronomia. Um belo exemplo é o Ritz Paris, o grande hotel que marcou a história das duas áreas. Fundado em 1898 do encontro de César Ritz e Auguste Escoffier, o edifício da Place Vendôme tornou-se referência em alta hotelaria e alta gastronomia, sendo frequentado por diversas personalidades - de Hemingway e Coco Chanel à Princesa Diana ${ }^{25}$. Foi dessa união

${ }^{25}$ Disponível em: <http://www.ritzparis.com/fr-FR/hotel-5-etoiles\#restaurants-et-bars>. Acessado em 04 de agosto de 2015. 
que nasceu a fama de Escoffier como um dos pais da Moderna Culinária Francesa, que até hoje é referência global em termos de gastronomia.

Sua fama [de César Ritz] como Diretor de Hotel se viu acrescentada com a
colaboração de Auguste Escoffier, o melhor chef de cozinha que houve no
mundo; mas foi Ritz quem soube valorizar Escoffier e que organizou todo o
'teatro' do serviço da sala de jantar. Há de se reconhecer que o talento de
Escoffier não teria alcançado sua fama se as louças, os talheres, os cristais, as
toalhas e guardanapos e a perícia de somelliers, garçons, ajudantes etc., sob o
cerimony master do chef de salão, não houvesse colaborado na apresentação
(FÚSTER, 1991, p. 52, tradução nossa).

Cria-se, com isso, o "mito" da gastronomia francesa, apoiada na alta-gastronomia ao mesmo tempo que na valorização dos produtos regionais. Poulain aponta a revolução de 1789 e sua departamentalização, desmantelando as províncias do antigo regime como um primeiro movimento de regionalismo da gastronomia. "As tradições alimentares, na sua função emblemática, tornam-se um lugar de resistência cultural" (POULAIN, 2013, p. 33). No entanto, há uma visão folclórica da tradição alimentar quando a culinária tradicional é vista como estável, imutável, 'autêntica' em oposição à artificialidade dos meios urbanos, às transformações da economia de mercado.

Nesse 'espaço autêntico', os produtos e as práticas repousariam em valores de uso e não em lógicas de distinção. Emerge, da demanda do consumidor, uma visão paradisíaca da ruralidade e a alteridade, elevada à classe de universo antropológico da harmonia dos homens entre si e com a natureza, uma utopia da ruralidade feliz (POULAIN, 2013, p. 33).

É nesse contexto que se cria o que o francês chama de "mitologia do paraíso culinário perdido" e que sociólogos e antropólogos são chamados à “ 'reconstrução' desses patrimônios” (POULAIN, 2013, p. 34). O fenômeno da patrimonialização da alimentação ganha força com esse movimento, unido ao crescimento do turismo. "Num contexto de expansão do turismo internacional, as tradições gastronômicas das zonas receptoras são agora consideradas, pelos atores da indústria turística, como um patrimônio a ser valorizado e como uma alavanca do desenvolvimento local" (BESSIÈRE, 2000; POULAIN, 1997a; TIBÈRE, 1997 apud POULAIN, 2013, p. 37).

Assim, voltamos à questão debatida no início deste capítulo, da capacidade do turismo de alterar a paisagem local, seja ela arquitetônica ou alimentar. Para Poulain, as hamburguerias e pizzarias que surgem em todas as partes do globo são produtos transculturais, possibilitados pelo turismo.

O turismo internacional desempenha aqui um papel de primeiro plano. Se a mundialização nivela certas diferenças, ela é ao mesmo tempo o motor de um processo de diversificação-integração. Ela implica, ao mesmo tempo, novas diferenciações, resultando formas originais de apropriação de produtos ou de 
técnicas e o desenvolvimento de espaços comuns que servem de ponte entre os modelos alimentares (POULAIN, 2013, p. 42).

No entanto, mais do que como adequação, é como reação a esses processos de homogeneização de paisagens que se estabelece o conceito francês de terroir.

O terroir é uma fórmula, oficializado em 1935 pela lei sobre os AOC [artigos de origem controlada, em tradução literal, em equivalência às Indicações Geográficas, no Brasil], emprestado pela crítica gastronômica à nova ciência geográfica que se constituía na mesma época, em uma atmosfera claramente patriótica (ORY, 2013, pp. 57-58).

A noção de terroir apresenta-se, portanto, como uma ferramenta de diferenciação e de proteção dessas diferenças e, nessa perspectiva, como uma construção do nacionalismo. A regionalização não é uma negação do nacional, pelo contrário, é uma tentativa de reforçar o patriotismo. Um século depois das primeiras publicações do Touring, a França lança um projeto inédito de inventariação de seu patrimônio alimentar. Em 1989, criou-se o CNAC (Conseil National des Arts Culinaire), que era composto por cinco Ministérios (Cultura, Agricultura, Educação, Turismo e Saúde), por chefs de cozinha, empresários e personalidades da área. Equipes de antropólogos e historiadores redigiram, nos 10 anos seguintes, um conjunto de 22 tomos, cobrindo quase todas as regiões do país, com fichas de produtos organizadas com rubricas idênticas, contendo a descrição, o histórico, os usos e o saber-fazer. O inventário não continha receitas nem vinhos e registrou, em média, 100 produtos por região, num total de mais de 2200 referências de todo o território francês (BIENASSIS, 2011).

Iniciativa essa que, para alguns especialistas, como o sociólogo brasileiro Carlos Alberto Dória, foi essencial para o fortalecimento do turismo gastronômico no país:

Por esse trabalho de revalorização da cozinha regional com ênfase em seus aspectos considerados 'gourmets', a cozinha francesa pode, agora, vangloriarse de uma riqueza e autonomia do gosto popular, que foram deixadas de lado ao longo do processo de centralização política, mas que, conforme a patrimonialização mostrou, não desapareceu (2014, p. 144).

Entretanto, o processo de patrimonialização especificamente é bastante criticado entre franceses. Primeiro, porque ele não terminou de inventariar todo o país. Segundo, porque ele não foi seguido de nenhuma outra ação, tornando-se apenas um retrato de museu do que era o patrimônio alimentar nacional àquela época, já que muitos dos produtos desapareceram nos 17 anos subsequentes (ORY, 2013). No entanto, o projeto foi de certa forma retomado nos últimos anos, quando a França apresentou à Unesco um dossiê para o reconhecimento da "Refeição Gastronômica dos Franceses" como patrimônio cultural imaterial da humanidade. O 
reconhecimento veio em 2010 e tem sido utilizado como ferramenta de incremento turístico no país.

A refeição gastronômica enfatiza o estar junto, o prazer do gosto e a harmonia entre seres humanos e produtos da natureza. [...] A refeição gastronômica deve respeitar uma estrutura fixa: ele começa com um aperitivo (bebidas antes da refeição) e termina com um licor digestivo, contendo entre os dois pelo menos quatro pratos, a saber uma entrada, peixe e/ou carne com legumes, queijo e uma sobremesa. (UNESCO) $)^{26}$

É interessante observar que dois conceitos emergem desse discurso: o de terroir, produto da relação entre homens e natureza; e o de tipicidade, ao exigir o respeito à estrutura da refeição - mesmo que esse modelo seja uma invenção recente (POULAIN, 2013). Tratamse de conceitos tornados referência a partir da valorização regional e da regulação, já em 1935, das $\mathrm{AOCs}^{27}$. Não é que a associação da qualidade de um produto ao seu lugar de origem não existisse desde o Império Romano. "Quanto aos produtos de qualidade, não é raro que sejam identificados pelo nome de sua procedência: Plínio fala do rábano de Nursia e do nabo de Amiternum” (CORBIER, 1998, p. 227). Entretanto, é apenas no século XX que a sistematização das Indicações Geográficas passa a agregar valor a esses produtos.

[...] 'produtos da terra' protegidos com Denominações de Origem, Indicações Geográficas Protegidas ou outras etiquetas de 'qualidade', [...] esses catálogos enfatizam não apenas a qualidade superior desses produtos, sua especificidade, seu caráter diferenciado - mas também e talvez sobretudo, sua profunda 'localidade', sua estreita vinculação com um território e seus habitantes. Característica que identifica genericamente este tipo de produtos, mas que se mostra exclusiva de cada território (ESPEITX, 2004, p. 199).

Nessa perspectiva, as Indicações Geográficas apresentam-se, em diferentes países, como instrumento de desenvolvimento local.

As IGs constituem um dos modelos até agora mais exitosos de apropriação do patrimônio territorial e se relacionam intimamente com outro mecanismo de capitalização, o turismo, especialmente quando este assume o formato de rotas alimentares. A natureza, o território e suas tradições dão significado simbólico e favorecem a inserção em nichos de mercado dos alimentos que, por seu caráter histórico, ou por estratégias comerciais exitosas, conseguem embeberse dessa identidade. As rotas alimentares jogam um papel importante em ambos os casos, validando uma imagem ou a construindo (BARRERA; BRINGAS, 2009, p. 3).

\footnotetext{
26 Disponível em http://www.unesco.org/culture/ich/fr/RL/le-repas-gastronomique-des-francais00437? RL $=00437$. Consultado em 23 out. 2016. Tradução nossa.

${ }^{27}$ Trata-se aqui da instituição das AOCs na França. Como política da União europeia, elas são estabelecidas apenas em 1992 e, mundialmente, em 1995, com a Rodada do Uruguai, que culminou com a criação da Organização Mundial do Comércio (OMC) e com a assinatura do Acordo sobre Aspectos dos Direitos de Propriedade Intelectual relacionados ao Comércio - ADPIC ou TRIPS.
} 
A visão apresentada por Barrera e Bringas se assemelha ao discurso dos órgãos oficiais, responsáveis pela certificação, tendo uma aproximação bastante positiva de seu impacto. As críticas ao processo de certificação, entretanto, e ao seu caráter excludente - uma vez que ele delimita áreas e modos de fazer - são bastante recorrentes, da França ao Brasil.

Ainda parece existir um acordo generalizado em torno do qual as rotas constituem uma estratégia de apropriação do território, aflora, ainda que sem se tornar explícito, um certo antagonismo entre a visão europeia e a do novo mundo sobre a temática das Indicações Geográficas, merecendo uma menção dado seu vínculo com as rotas (BARRERA; BRINGAS, 2009, p. 16).

Independente da discussão acerca das IGs, que aprofundaremos no próximo capítulo, o desenvolvimento de rotas alimentares ou rotas de vinho, bastante presente tanto na Europa, quanto em países como Chile e Argentina, mostra-se uma forma de aliar turismo e gastronomia com potencial ainda a ser explorado.

A importância de rotas alimentares e de vinhos ainda é subestimada: para algumas regiões, rotas de vinho podem representar um tipo de algo mais em adição a uma oferta turística já muito rica em termos de tours tradicionais (história, arte, monumentos, etc.), para outras regiões, nada famosas em termos de turismo, elas podem se tornar uma ferramenta fundamental para estimular a economia local. É verdadeiro que rotas de vinho permitem ao turista/consumidor aprender muito sobre o território e descobrir as ofertas turísticas tradicionais de uma região (BUIATTI, 2011, p. 99).

As Indicações Geográficas não são, entretanto, o único fator estimulante da busca de novos modelos turísticos aliados à alimentação. Há 30 anos, um outro movimento alimentou essa valorização do turismo gastronômico: o Slow Food.

Ao fim dos anos 1980, o pacto de não agressão entre a gastronomia, o desenvolvimento turístico e a indústria agroalimentar entra em crise. A uniformidade dos campos convertidos em cultivo financiados pela Comunidade Europeia, o superpovoamento das costas e a desertificação da montanha, as indústrias de férias com sua política alimentária centralizada, o nascimento de forma mais e mais agressivas de restauração, das pizzarias aos fast foods, fazem romper o escândalo e marcam um ponto de retorno na cultura italiana. Para fazer turismo gastronômico não é necessário apenas um meio de transporte, um hotel e um restaurante, mas precisa-se também de uma política agrícola durável, se não quisermos que a palavra terroir perca todo seu significado. (CAPATTI, 2006, p.8)

É nesse contexto, que surge o Slow Food. O nome é cunhado em 1986, em oposição ao modo de vida representado pelo fast food, em uma ação para impedir que um McDonald's se instalasse na Piazza d'Espagna, ponto central de Roma.

Nascido sob o nome de Arcigola e fundada em 1986, no Piemonte [Itália], por Carlo Petrini, Slow Food se torna internacional em 1989 como "Movimento pela tutela e pelo direito ao prazer" e um manifesto de intenção que põe a associação como antídoto à "Loucura universal da "fast life" e "Contra aqueles, e são a maioria, que confundem a eficiência com o frenesi, (aos quais) 
propomos a vacina de uma adequada porção de prazer assegurada, a ser praticada em prazer lento e duradouro". Se iniciava na mesa, no prazer garantido da convivialidade, história e cultura local, para chegar a uma nova gastronomia que pressupõe ainda uma nova agricultura, onde a sustentabilidade (ambiental e social) é imprescindível. (SLOW FOOD) ${ }^{28}$

Assim, em 1990, o movimento e sua recém fundada editora publicam seu primeiro guia - e seu best seller: Osterie d'Italia. A associação, que prega um alimento bom, limpo e justo, passa a ganhar adeptos em outros países da Europa e logo em outros continentes ${ }^{29}$. Valorizando os pequenos produtores locais, as tradições alimentares e divulgando-as, o movimento associa o turismo ao desenvolvimento local, a fim de garantir a continuidade da cultura alimentar da região.

Para os turistas, essa ação se concretiza pela transparência dos alimentos, pelos mercados revitalizados diretamente pelos produtores, por uma cozinha diretamente conectada com o terroir, por um trabalho de informação, de educação incessante. Da mesma forma que o visitante dos museus é responsável pela conservação dos quadros e estátuas, o gastrônomo cuida dos alimentos que consome, pois ele é um dos raros que conhecem o seu valor. (CAPATTI, 2006, p. 9)

O Slow Food, através de suas atividades e publicações, passa a aproximar os pequenos produtores dos consumidores finais - tornando estes, nas palavras de Petrini, "co-produtores". E isso acaba por ter um impacto direto no turismo local.

Não existe um 'turismo gastronômico slow', ${ }^{30}$, mas se nós o pudéssemos imaginar, a ele se atribuiria certamente um papel bastante ativo na conservação do patrimônio alimentar. Hoje em dia, numerosos turistas viajam para a Itália apenas para visitar e degustar; é preciso lhes assegurar o prazer de obras de arte sob a forma de garrafas de vinagre, de pratos de rabanetes ou de cestos de cerejas. (CAPATTI, 2006, p. 10)

Como ressalta Elena Espeitx (2004), quando o consumo de um certo produto alimentar se dá em um contexto de viagem, fora da rotina, e ainda mais quando se trata de um produto com uma reputação de qualidade, o turista o valoriza ainda mais. Além disso, ele tem a oportunidade de adquirir diretamente do produtor e levar para o seu cotidiano, um alimento diferente do que se encontra usualmente em supermercados e comércios. Além disso, ressalta Cazelais, as publicações do Slow Food fogem do formato tradicional dos guias convencionais, como Michelin ou GaultMillau, uma vez que elas não se atêm a restaurantes, mas tratam de

\footnotetext{
${ }^{28}$ Disponível em http://www.slowfood.it/chi-siamo/storia/. Consultado em 23 out. 2016.

${ }^{29}$ No Brasil, o Slow Food estabelece seu primeiro convívio em 2000, no Rio de Janeiro, mas só é oficialmente fundado em 2004: é um caso único na história do movimento, que se estabelece no país através da assinatura de um acordo de cooperação diretamente com o Governo Federal (GENTILE, 2016).

${ }^{30}$ Há, atualmente, um projeto nessa direção, que será apresentado no próximo capítulo.
} 
toda a cadeia produtiva do alimento, do campo à mesa. "De maneira que, a noção e mesmo os papeis dos guias são transformados" (2006, p. 7).

O turismo gastronômico pode ser, e em muitos casos já é, uma força propulsora para os produtores rurais repensarem sua atividade produtora levando em conta a diversificação em novos mercados e as oportunidades de obter um valor adicional em seus produtos. Isso está alinhado à filosofia do Slow Food, que é a de alcançar mudanças de longo prazo em áreas de biodiversidade, preservando alimentos ameaçados e fortalecendo economias locais através de assistência a pequenos produtores e construindo cadeias curtas de fornecimento; educação do gosto, criando uma melhor compreensão e apreciação da importância da conexão entre saúde, cultura alimentar local e agricultura; e, finalmente, comunidades do alimento, conectando produtores a consumidores, sensibilizando para a conscientização de casos exemplares de agricultura sustentável e produção alimentar artesanal (BUIATTI , 2011, p. 94).

Percebe-se assim que, seja motivado pelas Indicações Geográficas, por catalogações ou ações de organizações do terceiro setor ou por projetos governamentais, o caminho que se aponta para que o turismo retome seu valor de encontro, está na valorização das comunidades locais e suas diferenças culturais. É nesse ponto que entra a cultura alimentar e a valorização da gastronomia local, com suas especificidades, sua memória e identidade.

Uma política pública de Turismo deve ter como concepção o Turismo como um sistema aberto, orgânico e complexo que se coloque como atividade multissetorial, cuja execução deve, necessariamente, incorporar visões multidisciplinares, multiculturais e multissociais. Assim, se constituirá no trabalho conjunto do setor público com a iniciativa privada e com a sociedade civil, reconstruindo os processos de identidade tão necessários às cidades e às localidades, para que se integrem às redes de globalização de forma independente, em vez de serem homogeneizadas nesse processo (GASTAL; MOESCH, 2007, p. 45).

Não se trata, portanto, de ignorar os aspectos econômicos do turismo, mas não os colocar como prioridade, acima do bem-estar das populações locais e dos turistas. Nesse sentido, pode-se valorizar a cultura local, ressaltando o que a diferencia de outras, seja na música, na arte, nas tradições ou na gastronomia, tornando-a o grande atrativo turístico da região. No mesmo processo global, abordado anteriormente, que vem ocorrendo com a gastronomia brasileira. Dessa forma, cria-se um produto exclusivo e se valoriza a identidade cultural da população autóctone. "Estudos recentes destacam que, cada vez mais, o que é consumido não são produtos e serviços por si mesmos, mas a aura a eles agregada que se torna significado ou signo emancipado do produto em si” (GASTAL, 2005, p. 56).

Nesse sentido, ressaltam Hjalager e Richards, “Turistas são grandes consumidores de produtos gastronômicos, não apenas quando eles estão de férias, mas também quando eles retornam para casa" (HJALAGER; RICHARDS, 2002, p. 225). É nessa perspectiva que os 
inventários do patrimônio alimentar brasileiro podem ser utilizados para políticas públicas de fomento do turismo gastronômico no país. Não se trata, mais uma vez, de ignorar o turismo como um fenômeno de grande escala, mas valorizar a identidade cultural única de uma população. Ou seja, o turista, ao visitar o Brasil, deve ter contato a gastronomia brasileira, com suas especificidades locais, com seus saberes-fazer e não apenas opções de uma culinária internacionalizada. Esta última pode ser encontrada em qualquer lugar do mundo, não acrescenta à experiência turística de encontro com a cultura do local visitado. Como defende Lody (2008), a comida mostra-se o 'registro sensível' de uma cultura, de um lugar.

Para se alcançar esse objetivo deve-se, no entanto, passar pelo empoderamento da população que ali vive. Isso significa que as políticas públicas não devem ser impostas, mas pensadas, discutidas e construídas com os atores mais interessados, aqueles que construíram e habitam aquela região. E é nesse ponto que entra a gastronomia, como um dos fatores a serem trabalhados. Assim, Krippendorf propõe:

As especialidades culinárias e os pratos regionais devem figurar com destaque nos cardápios. E isso não exclui algumas pequenas adaptações (menos tempero, por exemplo) que às vezes são necessárias e podem ser realizadas sem maltratar a cozinha tradicional. É preciso reduzir a oferta da cozinha dita internacional. Também é preciso favorecer as bebidas locais tradicionais (2000, p. 157).

Assim, a valorização da cultura alimentar local, da gastronomia brasileira - portadora de identidade e memória - aponta-se como um dos caminhos para que o turismo passe a ser um fenômeno do encontro com o Outro, de troca de culturas e experiências e não seja apenas um produto mercadológico. No passo que os inventários do patrimônio alimentar nacional garantam às populações locais a salvaguarda de suas tradições e sua subsistência, o turista poderá experienciar em sua viagem pelo Brasil um pouco mais da cultura daquela singular localidade. 


\section{A PRODUÇÃO DE SENTIDOS NOS INVENTÁRIOS}

Uma vez que discutimos todo o percurso dos processos de inventariação do Patrimônio Alimentar Brasileiro e sua importância para a Salvaguarda da cultura, memória e identidade das populações que formam o país, chegamos à nossa pergunta: Há alguma relação entre os diferentes inventários do patrimônio alimentar nacional e o fomento do turismo no país?

Para tornar possível o estudo em tela, foi feito um recorte no qual optou-se por analisar três inventários:

- A Salvaguarda de Bens Imateriais do IPHAN (Instituto de Patrimônio Histórico e Artístico Nacional) - um órgão do Estado;

- O registro de Indicação Geográfica Protegida (IGP) do INPI (Instituto Nacional da Propriedade Industrial) - uma autarquia estatal (que desenvolve parte do processo em parceria com uma entidade privada, o SEBRAE);

- O projeto "Arca do Gosto" do Slow Food - associação internacional sem fins lucrativos voltada para a defesa de uma alimentação à base de produtos locais, de qualidade e que defendam as tradições e o meio ambiente.

Os inventários e instituições brasileiros foram selecionados por corresponderem a projetos, processos e atores pilares na construção do debate internacional da patrimonialização da cultura alimentar e da relação de turismo e gastronomia. Além disso, tratam-se de inventários nacionais, com potencial para integrarem políticas públicas, e não de projetos localizados.

Para tal estudo, as perguntas que orientaram o processo foram: os três diferentes inventariados selecionados se relacionam de alguma forma? Quais as funções que eles exercem atualmente? Neste capítulo, portanto, traçaremos a trajetória da construção desses inventários, aprofundando, através de nossas reflexões metodológicas, em sua produção de sentidos.

Para alcançar nossos objetivos, pareceu-nos que a metodologia da análise documental seria a mais adequada. Entretanto, logo de início nos deparamos com uma grande dificuldade: a pouca bibliografia sobre o tema. Nos campos da administração, psicologia ou das ciências sociais, a análise documental é, na maioria das vezes, vista como um método complementar de pesquisa. É na história que se valoriza o documento e se reforça o seu valor como fonte de pesquisa.

A escassez de manuais que lidem com a análise documental é um fenômeno intrigante. Talvez tenha algo a ver com o fato de que o trabalho qualitativo, especialmente na tradição antropológica, foi desenvolvido examinando a vida em sociedades não letradas - nas quais documentos aparentemente desempenhavam um papel menor. Talvez, entretanto, também tenha a ver com o fato de que, assim como o moderno filósofo francês Jacques Derrida 
argumentou persistentemente, nas metafísicas do mundo ocidental, a fala sempre foi privilegiada em relação à escrita. O que é escrito é então sempre reconhecido como secundário, marginal e subsidiário. (PRIOR, 2003, p. IX, tradução nossa)

Por ainda ser um método pouco debatido, a análise documental enfrenta também obstáculos de desconhecimento. Há confusões e diferentes entendimentos das funções desse tipo de metodologia. Trabalhos como o de Soares et al, demonstram que muitos dos pesquisadores que se utilizam da análise documental, não a conhecem completamente. Os pesquisadores analisaram 88 artigos publicados entre os anos de 2006 e 2010 em Anais de eventos científicos da ANPAD - Associação Nacional de Pesquisa e Pós-Graduação em Administração. Todos faziam uso ao menos de uma das três técnicas: Análise Documental, Análise de Conteúdo e Análise do Discurso. O resultado corrobora com a afirmativa de Prior (2003), de que há pouca literatura acerca do tema:

Confusões a serem observadas no decorrer deste estudo, aqui indicadas como possíveis atos ingênuos ou descompromissados de pesquisadores no uso de técnicas de análise de dados em prol da boa pesquisa qualitativa: a) na Análise de Conteúdo, fazer referência a uma das principais autoras e obras da área [Análise de Conteúdo, de Laurence Bardin], mas não esclarecer o seu rigor metodológico, com adequada descrição de sua sistemática; b) na Análise Documental, utilizar esta técnica tanto para a coleta, quanto para análise de dados, sem sua adequada exposição de uso durante o percurso metodológico da pesquisa; c) na Análise do Discurso, apesar de sua adequabilidade para o estudo de determinados objetos de pesquisa, sua aparente complexidade ou desconhecimento tem induzido o baixo uso desta técnica em administração pública (SOARES et al., 2011, p. 2).

Para o sociólogo Tim May, apesar da riqueza que se pode extrair de documentos, as pesquisas baseadas neles podem se sujeitar a serem mal compreendidas. Além disso, a análise documental não é uma categoria bem definida como, por exemplo, entrevistas ou observação participante. Uma vez que dizer que usará documentos não define como ele será trabalhado, explica, faz com que muitas vezes a análise documental não seja considerada como um método (MAY, 2011). Há ainda outros autores, como Laurence Bardin, que tratam a análise documental como uma técnica com objetivos limitados - como "uma fase preliminar da constituição de um serviço de documentação ou de um banco de dados" (BARDIN, 2002, p. 46). Nessa perspectiva, a análise de documentos não se sustentaria como única ou principal metodologia de pesquisa.

Por outro lado, Lindsay Prior (2003) e André Cellard (2012) estão entre os autores que defendem que a análise documental é uma metodologia que se sustenta. "Por possibilitar realizar alguns tipos de reconstrução, o documento escrito constitui, portanto, uma fonte extremamente preciosa para todo pesquisador nas ciências sociais" (CELLARD, 2012, p. 295). 
Mais do que isso, acrescenta o autor, o documento traz, além da compreensão do social, a dimensão do tempo (CELLARD, 2012).

Documentos, e especialmente os escritos, podem ser considerados obras e campos de pesquisa por si só. Em particular, o estudo dos processos de produção e consumo (ou uso) de materiais escritos proporciona dois pilares robustos em tornos dos quais interessantes e essenciais programas de pesquisa podem ser construídos e desenvolvidos. (PRIOR, 2003, p. 166, tradução nossa)

E é nessa vertente que este trabalho se apoia. Para tanto, ao iniciar a pesquisa, as primeiras preocupações que se enfrenta, ao fazer uma análise documental é a delimitação e avaliação dos documentos a serem trabalhados. O que é documento? As definições são muitas. De acordo com o dicionário Houaiss, documento é "qualquer objeto que comprove, elucide ou registre um fato" (HOUAIS; VILLAS, 2003, P. 176). "Um documento pode ser algo mais do que um pergaminho poeirento: o termo designa toda fonte de informações já existente" (LAVILLE; DIONNE, 1999, p. 166). Mais do que algo escrito, pode ser considerado documento um mapa, uma arquitetura, um vídeo e toda uma infinidade de produtos que remetem aos traços dos seres humanos.

Definir o documento representa em si um desafio. Pelo fato de o documento constituir uma de suas principais ferramentas, a história, de todas as ciências sociais, foi a que atribui maior importância a essa definição. [...] Privilegiando uma abordagem mais globalizante, a história social ampliou consideravelmente a noção de documento. De fato, tudo o que é vestígio do passado, tudo o que serve de testemunho, é considerado como documento ou 'fonte', como é mais comum dizer, atualmente. (CELLARD, 2012, p. 296)

Para Prior, a definição vai para além de traços humanos. Ele defende que documentos não são individualmente produzidos, mas "são essencialmente produtos sociais. Eles são construídos conforme regras, eles expressam uma estrutura, eles são situados com um discurso específico e a presença deles no mundo depende da ação, coletiva, organizada" (2003, pp. 1213).

Aliás, é nesse ponto que o sociólogo britânico apoia sua tese de que a análise documental é rica o suficiente para ser considerada uma metodologia: “Campos ou redes de ação, é claro, envolvem criadores (agentes, escritores, editores, publicitários etc.), usuários (leitores ou destinatários) e contexto. Todos os três campos estão implicados no surgimento da documentação" (PRIOR, 2003, p. 2).

Uma das principais vantagens apontadas do uso de documentos na pesquisa é a objetividade. Como ressalta Cellard, "é impossível transformar um documento; é preciso aceitálo como ele se apresenta, tão incompleto, parcial ou impreciso que seja" (2012, p. 299). No 
entanto, há também algumas armadilhas que o pesquisador de documentos pode cair. E é nesse ponto que a metodologia é questionada.

O primeiro ponto é a seleção de documentos pertinentes ao objeto de estudo. O pesquisador deve, ao escolher a sua base de textos (ou fotos, ou vídeos, etc.) a serem trabalhados, avaliar a sua credibilidade e a sua representatividade (CELLARD, 2012).

\begin{abstract}
A pesquisa documental exige, desde o início, um esforço firme e inventivo, quanto ao reconhecimento dos depósitos de arquivos ou das fontes potenciais de informação, e isto não apenas em função do objeto de pesquisa, mas também em função do questionamento [...]. Nesse estágio, o principal erro consiste em se precipitar sobre o primeiro bloco de documentos obtido, antes de realizar um inventário exaustivo e uma seleção rigorosa da informação disponível. É importante aprender a decodificar e utilizar os instrumentos de pesquisa preparados pelos arquivistas, a fim de assimilar a lógica que presidiu à classificação da documentação. (CELLARD, 2012, p. 298)
\end{abstract}

Nesse ensejo, optou-se neste trabalho pela seleção de documentos oficiais das três instituições analisadas. Como se tratam de um órgão do Estado, uma autarquia estatal e uma associação internacional sem fins lucrativos, tal escolha nos garantiria não apenas a credibilidade, mas uma perspectiva de construção da fala oficial dessas instituições. Também se priorizou os documentos escritos, uma vez que nosso objetivo era compreender o processo de inventariação desenvolvido por esses órgãos e associação - o que não significa que vídeos, fotografias não tenham feito parte de nossa análise ${ }^{31}$. Para tanto, levantou-se primeiramente o máximo de documentos relacionados aos processos de inventariação - tanto documentos de fonte primária, isto é, disponibilizados pelas instituições em questão, quanto trabalhos sobre os inventariados aqui analisados.

Fez-se necessária, portanto, uma sistematização do processo de seleção e análise da documentação. O primeiro passo, proposto tanto por Prior (2003) quanto por Cellard (2012), é o da composição de uma exaustiva busca por base documental. O pesquisador deve levantar o máximo de documentação possível para então definir seu recorte. Essa etapa proposta, assim como se observará em boa parte das seguintes, se assemelha muito à proposta pela grounded theory (CHARMAZ, 2009). A grande diferença é que nesta última metodologia, são os dados que guiarão o pesquisador a um problema de pesquisa e hipóteses. Na análise documental, parte-se já de um objeto, com seu problema e hipótese e a busca por uma base documental é feita referenciada neles. O que não significa que a pesquisa é rígida. "A flexibilidade é também rigor: o exame minucioso de alguns documentos ou bases de arquivos abre, às vezes, inúmeros

\footnotetext{
${ }^{31}$ Em uma etapa seguinte, foram ainda agregadas entrevistas semiestruturadas e observações participantes, em pesquisas de campo com as instituições, a fỉm de auxiliar-nos na compreensão do contexto em que tais documentos são criados e utilizados.
} 
caminhos de pesquisa e leva à formulação de interpretações novas, ou mesmo à modificação de alguns dos pressupostos iniciais" (CELLARD, 2012, p. 298).

Nessa perspectiva, é importante que o pesquisador, defina quais documentos serão analisados e quais serão excluídos. E que deixe bastante claro quais os critérios adotados para tal seleção (PRIOR, 2003). "Torna-se, assim, essencial saber compor com algumas fontes documentais, mesmo as mais pobres, pois elas são geralmente as únicas que podem nos esclarecer, por pouco que seja, sobre uma situação determinada" (CELLARD, 2012, p. 299). Percebe-se que, mesmo antes de iniciar a análise o pesquisador precisa fazer uma pré-avaliação crítica do material. Para isso, André Cellard propõe cinco dimensões do documento a serem destacadas: o contexto, o autor ou os autores, a autenticidade e a confiabilidade do texto, a natureza do texto e os conceitos-chave e a lógica interna do texto (CELLARD, 2012). Estes critérios basearam tanto a pré-análise dos documentos quanto o estudo pormenorizado daqueles selecionados que apresentaremos mais à frente.

O exame do contexto social em que o documento foi produzido permite ao pesquisador “compreender as particularidades da forma, da organização, e, sobretudo, para evitar interpretar o conteúdo do documento em função de valores modernos" (CELLARD, 2012, pp. 299-300). O ponto principal é que o documento não é atemporal, ele incorporará os valores de uma época e de uma população (autores e destinatários), ele tem um objetivo ao ser escrito. "Documentos devem ser interessante pelo que eles deixam de fora assim como pelo que eles contêm. Eles não refletem simplesmente, mas também constroem a realidade social e versões de eventos" (MAY, 2011, p. 199). Assim, ao optarmos por analisar as fichas de candidatura, os dossiês e as ações extras dos inventários de órgãos públicos e associação não governamental, interessa-nos perceber como as diferenças do contexto em que eles são elaborados refletem na seletividade de informações.

Dessa forma, para analisar um documento com todas suas intencionalidades é importante identificar o autor ou autores do texto. Mas para além da identidade. "Autoria de documentos é melhor retratada em termos de efeitos do que em termos de 'identidade' subjetiva. Como a função do autor é a questão que importa, mais do que quem ele ou ela é" (PRIOR, 2003, p. 104). Nessa mesma linha, a análise crítica do documento deve passar pela acessibilidade do documento - "por que esse documento, preferencialmente a outros, chegou até nós, foi conservado ou publicado" (CELLARD, 2012, p. 300).

É nesse ponto, a origem da documentação, que entra a questão proposta por Cellard de autenticidade e confiabilidade do texto. O autor chama a atenção para a necessidade de assegurar da qualidade da informação transmitida pelo documento - e essa pode ser avaliada 
pela familiaridade que o autor (ou autores) tem com o tema e pelos instrumentos de coleta de dados utilizados por ele. Outro fator que tem sua influência na composição de um documento é a natureza do texto. "Deve-se levar em consideração a natureza de um texto, ou seu suporte, antes de tirar conclusões. Efetivamente, a abertura do autor, os subentendidos, a estrutura de um texto podem variar enormemente, conforme o contexto no qual ele é redigido" (CELLARD, 2012, p. 302).

Por fim, Cellard ressalta a necessidade de avaliar os conceitos-chave e a lógica interna do texto.

\begin{abstract}
Delimitar adequadamente o sentido das palavras e dos conceitos é, aliás, uma precaução totalmente pertinente no caso de documentos mais recentes nos quais, por exemplo, utiliza-se um 'jargão' profissional específico, ou nos que contêm regionalismos, gíria própria a meios particulares, linguagem popular, etc. Deve-se também prestar atenção aos conceitos-chave presentes em um texto e avaliar sua importância e seu sentido, segundo o contexto preciso em que eles são empregados. Finalmente, é útil examinar a lógica interna, o esquema ou o plano do texto. (CELLARD, 2012, p. 303)
\end{abstract}

Uma vez selecionados os documentos a serem analisados, todos esses passos devem ser refeitos. "A maioria dos metodologistas concordam em dizer que é a leitura repetida que permite, finalmente, tomar consciência das similitudes, relações e diferenças capazes de levar a uma reconstrução admissível e confiável” (CELLARD, 2012, p. 304). Dessa forma, se constrói uma base sólida para a análise a ser desenvolvida. "Essa contextualização pode ser, efetivamente, um precioso apoio, quando, por exemplo, comparam-se vários documentos da mesma natureza" (CELLARD, 2012, p. 303).

Passa-se então à sistematização da análise em si. E é nesse ponto que se encontra a maior diferença de abordagem entre os autores que não percebem a análise documental como uma metodologia suficiente. Nessa perspectiva, a análise documental é apenas uma sistematização de dados que, para ir além e ser interpretada precisa da análise de conteúdo. O que Lindsay Prior (2003) propõe, entretanto, é uma análise documental para além da análise de conteúdo.

De fato, quando documentos são apresentados para consideração, aproximase deles usualmente em termos do seu conteúdo ao invés do seu status como 'coisas'. Isto é, o foco é geralmente na linguagem contida no documento como um meio de pensamento e ação. Ainda é bastante claro que todo documento se situa numa relação dualística com campos de ação (PRIOR, 2003, p. 3).

Essa ênfase no conteúdo ao invés do uso, reforça Prior (2003), acaba por concentrar os estudos no uso de documentos na pesquisa científica nos problemas de autenticidade ao invés dos problemas de uso e função. Por isso o sociólogo britânico propõe que o estudo de documentos enfatize seu contexto social, especialmente em como tais textos, vídeos, etc. são 
produzidos e qual a função deles ao invés de simplesmente o que eles contêm. Isso não significa que a análise de conteúdo não seja importante, no entanto. Ela é. Mas ela é mais uma etapa da análise documental e não necessariamente outra metodologia dissociada. Dessa forma, ao tratar dos documentos selecionados, optou-se neste trabalho por analisar também o seu conteúdo. Mas esse foi apenas mais um dos elementos de nosso exame. Assim, o contexto de cada documento, os autores e público-alvo, o formato, a linguagem e a acessibilidade também foram levados em conta.

Para além disso, o que Prior sugere é que

[...] quando olhamos o conteúdo de documentos são os esquemas de referência que precisam ser analisados ao invés dos sistemas de significação. Em outras palavras, nossa ênfase precisa ser nas atividades sociais através das quais os textos são apropriados ao invés das propriedades psicológicas do leitor (PRIOR, 2003, p. 24).

Ou seja, não significa desprezar o conteúdo dos documentos, mas perceber como mais valioso o que é referenciado no texto do que o significado da palavra em si. A análise de conteúdo concentrar-se-ia então no estudo dos padrões de referência - que comparados com o contexto poderiam então ser interpretados.

As sistematizações do documento e seu conteúdo proposta por autores das mais diversas correntes, como Bardin (2002), May (2011), Laville e Dionne, Cellard (2012) e Prior (2003) se assemelham bastante. O que se observa, na realidade, é que tais análises não têm métodos rígidos, mas sugestões de caminhos a serem trilhados que permitam um maior grau de imparcialidade na interpretação dos dados.

O recorte dos conteúdos constitui uma das primeiras tarefas do pesquisador após a fase preparatória. A definição das categorias analíticas, rubricas sob as quais virão se organizar os elementos de conteúdo agrupados por parentesco de sentido, é uma outra tarefa que se reconhece primordial. A ordem desses dois momentos da análise de conteúdo pode variar: às vezes, o pesquisador define primeiro suas categorias, mas em outros casos sua determinação é precedida do recorte dos conteúdos, especialmente quando essas categorias são construídas de maneira indutiva, isto é, ao longo dos progressos da análise. (LAVILLE; DIONNE, 1999, p. 219)

Laurence Bardin (2002) propõe nove passos entre a escolha e a preparação do material a ser analisado - dos quais muitos coincidem com os sugeridos por Cellard (2012): leitura flutuante; escolha dos documentos; regra da exaustividade; regra da representatividade; regra da homogeneidade; regra da pertinência; formulação das hipóteses e dos objetivos; referenciação dos índices e a elaboração de indicadores; e, por fim, preparação do material.

Pode-se notar alguns pontos em comum com a grounded theory (também conhecida, em português, por teoria fundamentada), cujos métodos baseiam-se em diretrizes sistemáticas, 
mesmo que flexíveis, para coletar e analisar os dados visando à construção de teorias que sejam “fundamentadas" nos próprios dados. "Essas diretrizes fornecem um conjunto de princípios gerais e dispositivos heurísticos, em vez de regras pré-formuladas. Assim, os dados formam a base da nossa teoria, e a nossa análise desses dados origina os conceitos que construímos" (CHARMAZ, 2009, p. 15).

Assim sendo, os pesquisadores adeptos da teoria fundamentada começam sua pesquisa pelos dados - construídos por meio de observações, interações e materiais que reuniram sobre o tópico ou sobre o ambiente. Após estudar os primeiros dados, começam a separá-los, classificá-los e sintetizá-los por meio da codificação qualitativa, isto é, associando marcadores a segmentos de dados que representam aquilo de que se trata cada um dos segmentos. Dessa forma, tem-se um instrumento que possibilita estabelecer comparações com outros segmentos de dados. Com a codificação, redigem anotações analíticas preliminares sobre os códigos e comparações - os memorandos (CHARMAZ, 2009).

Assim, construímos níveis de abstração diretamente dos dados e, posteriormente, reunimos dados adicionais para verificar e refinar as nossas categorias analíticas geradas a partir disso. Nosso trabalho culmina em uma 'teoria fundamentada' ou em uma compreensão teórica da experiência estudada. [...] Em resumo, os métodos da teoria fundamentada desmistificam o procedimento da investigação qualitativa - e aceleram a sua pesquisa, intensificando o seu estímulo em relação a ela. (CHARMAZ, 2009, p. 16)

No entanto, dois pontos fundamentais da grounded theory fizeram com que não optássemos por adesão a essa metodologia. O primeiro é ter os dados como fundamentos da pesquisa, sem referencial teórico anterior. O segundo, é ressaltado por Lindsay Prior:

A grounded theory supostamente permite que o insight teórico emerja dos dados, o pesquisador meramente rearranja e explicita aquilo que está implícito nos dados. No entanto, o fracionamento dos dados observados ou de conversar em pontos 'nodais'- baseados em temas e conceitos selecionados pelo pesquisador - e o rearranjo dos dados através do uso de memorandos e relatórios de pesquisa fundamentalmente altera os dados que foram perseverantemente coletados. Nesse sentido, o pesquisador cientista social invariável e inevitavelmente impõe uma nova ordem no mundo reportado pelos informantes dele ou dela (PRIOR, 2003, p. 141).

Dessa forma, o que se referencia da grounded theory aqui é seu ponto em comum com os instrumentos de análise documental e de conteúdo: o processo de categorização das informações do documento, que permitirá a sua análise posterior. De acordo com Bardin (2002) e Laville e Dionne (1999), se o processo de classificação dos dados em categorias e unidades for bem amarrado, com critérios de inclusão em cada uma destas bem definidos e nitidamente diferenciados, a sequência do trabalho é simples. Extenso, mas muito mais mecânico do que reflexivo. 
Em nossa pesquisa, seguimos a metodologia apresentada por Prior e Cellard. Após extensa leitura, foi possível definir quais o os documentos a serem analisados neste trabalho, a fim de responder nossas perguntas. Apresentamos aqui nossos objetos de estudo por instituição:

\section{IPHAN}

Optou-se por analisar o documento que instrui a formulação dos inventários de salvaguarda do patrimônio imaterial, o INRC, e compará-los aos dossiês gerados dos bens salvaguardados relacionados à tradição alimentar. São eles: Modo Artesanal de Fazer Queijo de Minas, Ofício das Baianas de Acarajé e Produção Tradicional e Práticas Socioculturais Associadas à Cajuína no Piauí (registrados no Livro de Saber-fazer). Há ainda, tangentes ao tema alimentação, outros quatro registros: Modo de Fazer Cuias do Baixo Amazonas, Ofício das Paneleiras de Goiabeiras, Sistema Agrícola Tradicional do Rio Negro e Feira de Caruaru. Entretanto, como esses registros não têm como foco um saber-fazer ou produto da tradição alimentar, optou-se por não incluí-los nesta análise.

\section{INPI}

Responsável no país pelas patentes, registros de marcas, o INPI atua no registro de Indicação Geográfica Protegida (IGP). É este processo, referente a produtos alimentícios que se pretende analisar. Assim como na análise do IPHAN, optou-se por estudar os formulários de candidatura de produtos para o registro e o dossiê produzido daqueles que obtiveram a Denominação de Origem ou a Indicação de Procedência. Atualmente, 25 produtos alimentícios, incluindo bebidas, têm Indicação de Procedência (IP) e seis têm Denominação de Origem $(\mathrm{DO})^{32}$. Por se tratar de um universo muito amplo, optou-se por analisar três produtos da catalogação, que também são registrados pelo IPHAN. Dessa forma, pode-se fazer uma comparação mais justa das diferenças entre os processos. Foram analisados neste trabalho, portanto, as Indicações de Procedência (IP) dos queijos da Canastra e do Serro e a da Cajuína.

\section{SLOW FOOD}

O movimento internacional que começou na Itália em 1989, tem como preceito a valorização do alimento bom, limpo e justo. Entre seus principais projetos, dois têm como foco a preservação da biodiversidade e tradição alimentar: Arca do Gosto e Fortalezas. O primeiro, criado em 1996, tem como objetivo de catalogar produtos em risco de desaparecimento. Ele conta atualmente com 118 produtos brasileiros ${ }^{33}$. O segundo, nascido três anos depois, é mais

\footnotetext{
32 Disponível em http://www.inpi.gov.br/menu-servicos/indicacao-geografica/pedidos-de-indicacao-geograficano-brasil. Acessado em 11 de abril de 2016.

${ }^{33}$ Até o primeiro semestre de 2016, haviam apenas 56 produtos brasileiros na Arca do Gosto. No entanto, em uma campanha lançada em fevereiro, visando o Terra Madre, evento que ocorreu em setembro e que será abordado mais adiante, outros 52 produtos do país foram catalogados. Há ainda outras 180 candidaturas em processo de
} 
complexo e envolve projetos de estímulo para que tais produtos não sejam extintos. São 11 os artigos brasileiros inventariados no Fortalezas. Seguindo os mesmos preceitos utilizados com os outros dois processos de inventariação, optou-se por analisar as fichas de candidaturas dos produtos à Arca do Gosto e compará-las com os dossiês apresentados pela instituição. Por também se tratar de um universo muito amplo, optou-se por seguir avaliando os produtos que se repetiram nas outras duas instituições analisadas. Assim, selecionamos para análise os dossiês dos queijos Canastra Artesanal, do Serro, da Serra do Salitre ou Alto Paranaíba e da Cajuína, este incluído em fins de setembro de 2016 no catálogo.

Retomando as dimensões do documento propostas por Cellard (2012), optou-se neste trabalho por tratar de documentos oficiais. Desta forma, a questão da credibilidade é assegurada. Apresentamos também algumas informações de contexto e autores de tais textos, que serão aprofundados ao longo do processo de análise. Como já abordado, esta foi nossa seleção documental a ser trabalhada. O que não significou que estivéssemos fechados para novos documentos ou instrumentos que a pesquisa apresentasse e que julgássemos essenciais para alcançar os objetivos aqui propostos e para responder às perguntas levantadas. Dessa forma, entrevistas semiestruturadas e observações participantes, em pesquisas de campo com as instituições, auxiliaram-nos a compreender o contexto em que tais documentos são criados e utilizados.

\subsection{A SISTEMATIZAÇÃO DOS DOCUMENTOS}

A primeira dificuldade no trato com os documentos foi criar categorias de análise. Por se tratarem de processos com intencionalidades diferentes, tema que aprofundaremos ao longo de nossa análise, as fichas de candidatura de novos bens a serem inventariados são bastante diversas. Assim, classificamos o material a ser trabalhado nas seguintes unidades: fichas de candidatura; dossiê do bem inventariado; ações complementares. As duas primeiras unidades ${ }^{34}$ foram então divididas em quatro categorias: dados referentes ao bem; dados referentes ao produtor/executante; dados referentes ao responsável pela candidatura do bem; documentos comprovatórios anexos. Dessa forma, podemos analisar cada um dos três processos e comparálos.

\footnotetext{
análise. Disponível em http://www.fondazioneslowfood.com/en/nazioni-arca/brazil-en/ $\mathrm{e}$ http://www.fondazioneslowfood.com/en/nazioni-segnala/brazil-en/. Consultado em 01 out. 2016.

${ }^{34}$ As ações complementares são muito díspares para serem categorizadas. Dessa forma, optou-se por analisá-las individualmente por instituição.
} 
Para tanto, foi necessário selecionar os dossiês a serem analisados. Como já explicado aqui, tomamos como referência os três atuais do IPHAN: Modo Artesanal de Fazer Queijo de Minas; Ofício das Baianas de Acarajé; e Produção Tradicional e Práticas Socioculturais Associadas à Cajuína no Piauí. Dessa forma, selecionamos três ou quatro em cada um dos outros inventários, sempre que possível, avaliando o mesmo produto, de forma a ter uma comparação mais justa entre os diferentes processos. Os queijos da Canastra e Serro e a Cajuína são os únicos a se fazerem presentes em todos os inventários. Por isso analisamos como cada instituição trata estes produtos. Assim, foram selecionados, do INPI: Indicação de Procedência (IP) - Canastra - Queijo; Indicação de Procedência (IP) - Serro - Queijo; e Indicação de Procedência (IP) - Cajuína. Por fim, da Arca do Gosto, do Slow Food: Queijo Canastra Artesanal; Queijo do Serro; Queijo Serra do Salitre ou Alto Paranaíba; e Cajuína.

Após a sistematização de todos os dados em planilhas, de acordo com essas unidades e categorias, passou-se à análise. Vale retomar a reflexão metodológica proposta por Prior (2003) e Cellard (2012) e ressaltar que este trabalho não se propõe apenas a fazer uma análise de conteúdo. Portanto, focou-se em compreender nos documentos aqui descritos o contexto, o autor ou os autores e sua função, a acessibilidade, a autenticidade e a confiabilidade do texto, a natureza do texto e os conceitos-chave e a lógica interna do texto. Concentrou-se, ainda, no estudo dos padrões de referência, para compará-los com o contexto e, dessa forma, poder interpretá-los.

\subsubsection{As Fichas de Candidatura}

A primeira unidade de análise estabelecida foi a das fichas de candidatura. Os instrumentos de coleta de dados são a primeira grande diferença entre os três processos de catalogação. Enquanto os formulários apresentados pela Arca do Gosto do Slow Food e pelo pedido de registro de IG do INPI são bastante concisos, as F10: Ficha de Identificação - Sítio e Ficha 60: Ficha de Identificação - Ofícios e Modos de Fazer do INRC ${ }^{35}$, do IPHAN, são extensas e detalhadas. Dois pontos podem ser refletidos a partir dessas diferenças. O primeiro é para quem essas fichas estão disponíveis, qual o público elas pretendem acessar.

Por mais que o registro de bens de natureza imaterial pelo IPHAN possa ser proposto por entidades da sociedade civil de uma forma geral, os dossiês usualmente são construídos por

\footnotetext{
${ }^{35}$ O INRC possui ainda outras três fichas, esta são as duas que serviram de base para os dossiês analisados, uma vez que os três se encaixam na categoria de Ofícios e Modos de Fazer. Mesmo que o dossiê físico (disponível na sede do IPHAN em Brasília) da Produção Tradicional e Práticas Socioculturais Associadas à Cajuína no Piauí não contenha fichas do INRC, ao contrário dos outros dois, esses seriam os dados referentes ao dossiê final.
} 
pesquisadores - historiadores, antropólogos, sociólogos, entre outros. Assim, é possível (e necessário, para cumprir o objetivo desse instrumento) uma extensa lista de questões a serem respondidas. Além disso, as fichas do INRC não estão disponíveis junto com o manual, no site do Instituto. Para ter acesso a elas, é necessário solicitar autorização ao Departamento de Patrimônio Imaterial.

Aliás, essa foi a realidade encontrada por esta pesquisa. No entanto, em meados de 2016, o IPHAN lançou a publicação "Educação Patrimonial: Inventários Participativos", que busca exatamente tornar o processo de patrimonialização mais acessível. Este manual de aplicação apresenta, em linguagem acessível, todo o processo de inventariação, inclusive com as fichas, detalhadamente explicadas. Trata-se de um esforço claro de democratização do acesso à ferramenta de registro do patrimônio imaterial nacional.


Figura 3. Reprodução da publicação do IPHAN ${ }^{36}$.

Já a ficha de candidatura do Slow Food, simples e direta, com poucas informações a serem preenchidas, é aberta a todos que quiserem indicar um produto de sua tradição alimentar para compor o catálogo da Arca do Gosto. Como o movimento internacional é voluntário, o projeto depende de pessoas interessadas em registrar bens passíveis de integrar o catálogo. E

36 Disponível em http://portal.iphan.gov.br/uploads/ckfinder/arquivos/InventarioDoPatrimonio 15x21web.pdf. Consultado em 09 out. 2016. 
isso vai de cozinheiros a ativistas, de pequenos produtores a acadêmicos. Mesmo com a intenção de ser acessível a todos os públicos, um ponto chama a atenção nesta ficha de candidatura: ela é disponibilizada apenas online. Ou seja, para inscrever um produto é necessário que se tenha acesso a internet. Fator que, no Brasil, restringe bastante o alcance do projeto, uma vez que, de acordo com o IBGE (Instituto Brasileiro de Geografia e Estatística), em 2104 , apenas $54,9 \%$ dos domicílios no país possuíam acesso à rede, seja no computador, tablet ou celular ${ }^{37}$. Além disso, há discussões acerca das categorias de produtos que fazem parte ou não da catalogação - ponto que será melhor discutido mais à frente.

A ficha de candidatura mais enxuta é a do INPI. Tão curta que, sem orientação de um profissional já habituado ao processo, torna-se difícil entender quais documentos são necessários para conseguir a certificação de Indicação Geográfica. "O formulário é simplificado, mas o exame é bem profundo", argumenta Raul Bittencourt Pedreira, tecnologista responsável pelas IGs no $\mathrm{INPI}^{38}$. Outro fator a ser levado em conta ao analisar a ausência de informações na ficha é a parceria desenvolvida pelo INPI com SEBRAE e MAPA, que trabalham na identificação de possíveis Indicações Geográficas junto aos produtores. Assim, o formulário tende a ser preenchido com instruções de profissionais já com conhecimento prévio do processo.

O segundo ponto a ser refletido a partir das diferenças das fichas aqui analisadas é qual a intenção de cada um desses processos de inventariação e, consequentemente, desses formulários. Esse é um aspecto que será desenvolvido ao longo de toda a análise. Para começar, podemos explorar os objetivos declarados de cada um dos processos abordados neste trabalho:

\section{IPHAN}

O Decreto $n^{0} 3.551$, de 4 de agosto de 2000, que institui o registro de Bens Culturais de Natureza Imaterial, define no $\S 20$ que: “A inscrição num dos livros de registro terá sempre como referência a continuidade histórica do bem e sua relevância nacional para a memória, a identidade e a formação da sociedade brasileira" (BRASIL, 2000b, grifo nosso).

Trata-se, portanto de um discurso de valorização das diferentes populações e culturas que formam a "memória" e "identidade" da "sociedade brasileira". Retomamos, assim, a discussão já aqui desenvolvida de que essa mudança de foco é tentativa de democratização do processo de patrimonialização no país, que tem como marco a Constituição de 1988.

\footnotetext{
${ }^{37}$ Disponível em http://biblioteca.ibge.gov.br/visualizacao/livros/liv95753.pdf. Acessado em 28 set 2016.

${ }^{38}$ Entrevista feita em 20 de setembro de 2016. Esta entrevista foi uma das ferramentas adicionais utilizadas durante o processo de análise documental. Percebeu-se necessário o diálogo com profissionais da instituição como forma de complementação das informações necessárias para a compreensão de todo o contexto dos documentos aqui trabalhados.
} 
Dando continuidade à construção desse discurso, o manual de aplicação do Inventário Nacional de Referências Culturais (INRC), ferramenta utilizada como referência (apesar de não ser obrigatória) para a construção dos dossiês de registro do patrimônio imaterial pelo IPHAN, define dois objetivos principais de sua concepção:

1. identificar e documentar bens culturais, de qualquer natureza, para atender à demanda pelo reconhecimento de bens representativos da diversidade $\mathrm{e}$ pluralidade culturais dos grupos formadores da sociedade; e

2. apreender os sentidos e significados atribuídos ao patrimônio cultural pelos moradores de sítios tombados, tratando-os como intérpretes legítimos da cultura local e como parceiros preferenciais de sua preservação. (BRASIL, 2000a, p. 8)

Assim, o processo de registro de um bem, mesmo que construído por profissionais, precisa ser feito junto à comunidade detentora daquela cultura.

Orientar um trabalho de preservação a partir da noção de "referência cultural" [...] significa buscar formas de se aproximar do ponto-de-vista dos sujeitos diretamente envolvidos com a dinâmica da produção, circulação e consumo dos bens culturais. Ou seja, significa, em última instância, reconhecer-lhes o estatuto de legítimos detentores não apenas de um "saber-fazer", como também do destino de sua própria cultura. Não é preciso chamar a atenção para as implicações políticas dessa perspectiva, nem para seus limites em situações concretas, quando até o termo "comunidade" pode servir para encobrir interesses de grupos locais mais poderosos, de autoridades políticas, etc. (LONDRES, 2000, p. 19)

Nesse sentido, ao analisar as fichas de identificação do IPHAN e todos os seus anexos, que fazem parte do processo, pode-se perceber a tentativa de abranger todos os aspectos da complexidade de um bem cultural de natureza imaterial. As questões abarcam desde o histórico do bem naquela comunidade, passando pela descrição de todos os atores, ferramentas de trabalho, comidas e bebidas, músicas, locais etc. relacionados ao bem até chegar à sua destinação e aos bens associados. Ainda é possível identificar que os formulários deixam espaço para que a investigação não fique engessada apenas nos itens ali abordados, disponibilizando campos para a observação dos pesquisadores. Dessa forma, qualquer item não incluído pelo documento, pode ser adicionado ao dossiê final pelo profissional - permitindo agregar diferentes perspectivas.

É interessante atentar, no entanto, às intencionalidades intrínsecas na linguagem e acessibilidade aos documentos, como ressaltam Cellard (2012) e Prior (2003). Assim, percebese que o questionário é voltado para pesquisadores profissionais - historiadores, geógrafos, antropólogos, etc. - o que poderia tornar seu preenchimento mais complexo. Além disso, até 2016, o acesso às fichas era limitado. Isso modificou-se um pouco com o lançamento da publicação "Educação Patrimonial: Inventários Participantes”, citada anteriormente. 
É também notório que tais documentos servem apenas como referência. O uso do INRC não é obrigatório para que um bem seja inserido nos Livros de Registro do IPHAN. Mas é a ferramenta utilizada em dois dos três casos aqui analisados. Deve-se ressaltar ainda, que a metodologia do INRC e sua necessidade vêm sendo rediscutidas no IPHAN, a fim de aprimorar o processo de inventariação dos bens de natureza intangível.

Outro ponto importante a ser destacado das intencionalidades desse inventariado, é a constante atualização. Uma vez que se trata de registrar bens culturais, que estão em processo de construção e ressignificação contínuo e, portanto, não podem ser congelados, o decreto $\mathrm{n}^{\circ}$ 3.551/00 institui em seu artigo $7^{\circ}$ que: “O IPHAN fará a reavaliação dos bens culturais registrados, pelo menos a cada dez anos, e a encaminhará ao Conselho Consultivo do Patrimônio Cultural para decidir sobre a revalidação do título de 'Patrimônio Cultural do Brasil"” (BRASIL, 2000b).

Percebe-se que o objetivo da inventariação passa, necessariamente pelo respeito à dinamicidade dos bens culturais imateriais. Ou seja, uma vez que a população detentora de um bem cultural foi fortalecida, a ponto de ele não precisar mais de ações de salvaguarda ou, ao contrário, se o bem deixa de fazer parte da cultura daquela população a despeito das ações desenvolvidas por dez anos, ele pode não ter o título de "Patrimônio Cultural do Brasil" revalidado. É possível ainda identificar nessa questão a motivação primeira de impedir o desaparecimento do patrimônio cultural dos povos, gerado pelo processo de homogeneização resultante da globalização.

Como discutido anteriormente, a necessidade de inventariar o patrimônio cultural nacional nasce como reação à ameaça de perda desses bens, primeiramente materiais e, em um segundo momento, contemplando também os de natureza imaterial. Nessa perspectiva, os traços colonialistas do turismo de massa (KRIPPENDORF, 2000) desenvolvem um papel preponderante. Isso porque, ao impor padrões de hospedagem, alimentação e transporte "internacionais", a atividade turística acaba por descaracterizar a localidade, fazendo com que a cultura daquele território seja suprimida ou deslocada para outras áreas - juntamente com a população local, sua detentora. A busca por alternativas que impeçam que o fenômeno turístico de ter esse caráter colonizador, passa, inclusive, pelas ações de salvaguarda do patrimônio imaterial associadas ao turismo. Veremos alguns exemplos mais à frente.

\section{INPI}

O conceito de Indicações Geográficas Protegidas é introduzido no Brasil em 1996, com a promulgação da Lei da Propriedade Industrial 9.279 de 14 de maio do mesmo ano (LPI/96). Esta lei é uma consequência da Rodada do Uruguai, que se encerrou em 1994 e culminou com 
a criação da Organização Mundial do Comércio (OMC) em 1995. Na ocasião, o Brasil, como um dos signatários fundadores da organização, assinou o Acordo sobre Aspectos dos Direitos de Propriedade Intelectual relacionados ao Comércio - ADPIC ou TRIPS, exigindo que o país criasse uma lei nesse sentido.

Assim, ao contrário do que foi a construção das IGs na Europa, onde elas se originam, aqui ela se impõe de cima para baixo (CEDRON et al., 2011, p. 325). Não se trata, portanto, de uma demanda dos produtores. O que se percebe no processo no Brasil - e aí as parcerias do INPI com o SEBRAE e o MAPA são essenciais - é a necessidade de levar ao conhecimento dos produtores o que são essas Indicações.

Como se apresentam então as Indicações Geográficas no discurso oficial? Em documento lançado este ano pela ABNT, com a primeira de uma série de quatro normas ${ }^{39}$ construídas em parceria com as instituições que trabalham com as IGs, define-se:

A indicação geográfica é uma ferramenta coletiva de proteção e promoção comercial de produtos tradicionais vinculados a uma área geográfica delimitada. Além disso, é uma ferramenta de preservação da biodiversidade, do conhecimento, dos recursos naturais e humanos. A indicação geográfica pode contribuir para as economias locais e para o dinamismo regional.

A indicação geográfica deve promover os produtos e a sua herança históricocultural, que é intransferível. Esta herança abrange inúmeras especificidades: a área de produção definida, a tipicidade e a autenticidade dos produtos elaborados. Estas especificidades garantem ao produto um nome e notoriedade, que devem ser protegidos. Somente aos produtores estabelecidos na área delimitada e que seguem determinadas regras é reservado o uso do nome geográfico. Este conceito também se aplica aos serviços. (ABNT, 2016, p. v)

Percebe-se, portanto, um discurso que, apesar de tratar de herança histórica e cultural e proteção de tipicidade, foca na relevância econômica desses produtos e serviços. Essa aliás, é a maior crítica enfrentada pelas IGs: são meramente ferramentas voltadas para o mercado e, assim, excludentes e não capazes de salvaguardar o patrimônio cultural imaterial. Crítica, aliás, rebatida por todos os que trabalham com essa certificação, que reafirmam o que se lê em quase todos os materiais de divulgação:

As Indicações Geográficas são ferramentas coletivas de valorização de produtos tradicionais vinculados a determinados territórios. Elas possuem duas funções em principal: agregar valor ao produto e proteger a região produtora [...]. Trazem contribuições extremamente positivas para as economias locais e para o dinamismo regional, pois proporcionam o real significado de criação de valor local. (GIESBRECHT et al., 2014, p. 18)

\footnotetext{
${ }^{39}$ Em 2014 começou-se a construir com a ABNT quatro normas para as IGs. A primeira, de Terminologia, foi lançada em 2016. A de Estruturação sairá em breve. Ainda estão em elaboração as de Gestão e Rastreabilidade.
} 


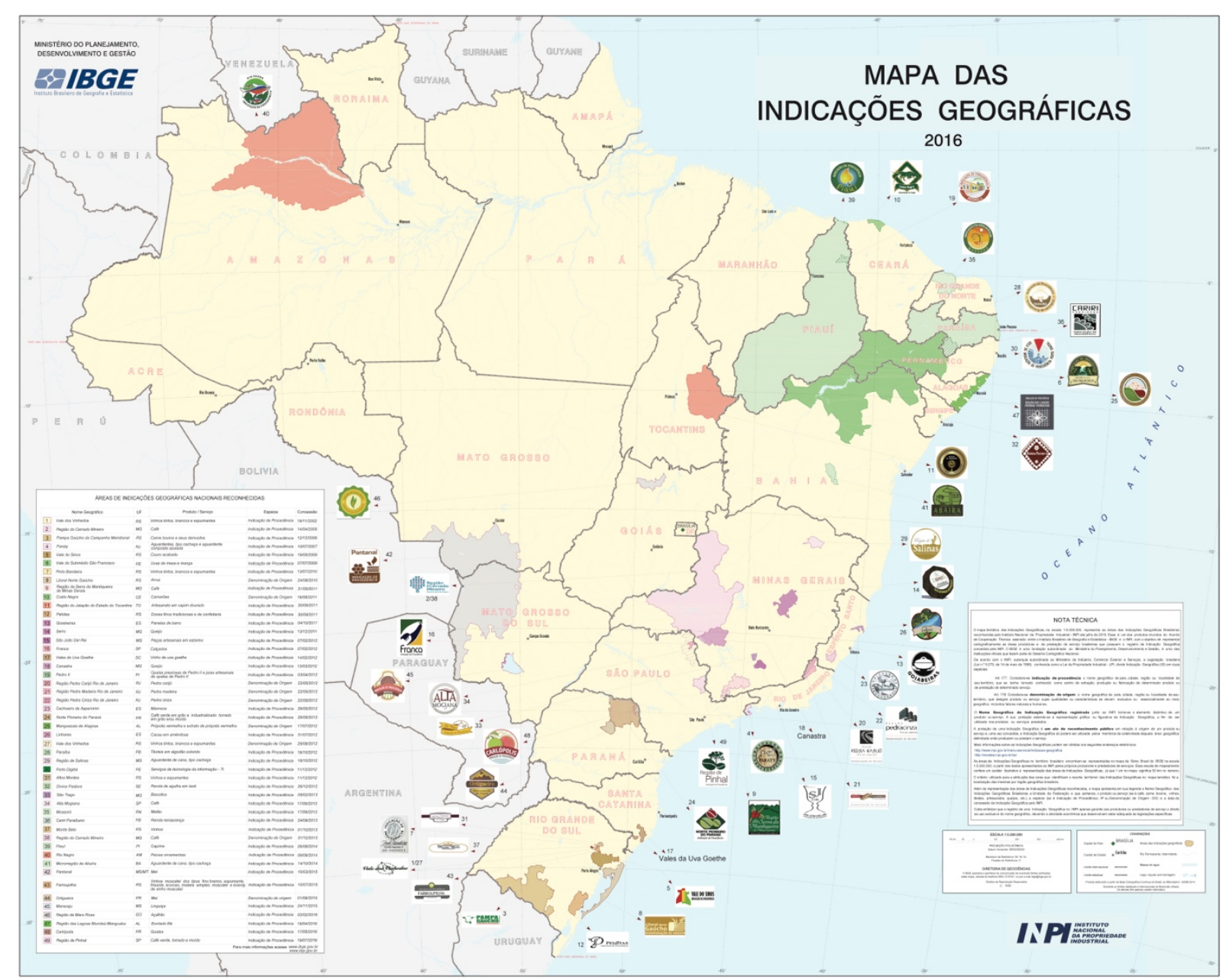

Figura 4. Mapa das Indicações Geográficas do Brasil. Fonte: IBGE ${ }^{40}$.

Essa discussão será aprofundada ao longo de nossas análises. Mas um ponto a ser levado em conta aqui é a estranheza de diferentes atores encontrados ao longo dessa pesquisa ao serem confrontados com a ideia de que as IGs seriam um inventário. Acadêmicos e até mesmo profissionais envolvidos com o processo se surpreenderam com a classificação. Para eles tratase de uma certificação apenas. Cabe, pois, esclarecer que neste trabalho parte-se do conceito de inventário como definido no dicionário Michaelis: "Elaboração minuciosa; registro, relação, rol” (TREVISAN, 2015). Portanto, as três diferentes formas de catalogação aqui analisadas se encaixam no perfil de inventários, mesmo que tenham processos e intencionalidades diferentes.

Por fim, vale ressaltar mais uma vez o discurso de objetividade, bastante presente nos documentos de regulação e instrução do INPI. Apesar de tanto no IPHAN quanto no Slow Food o termo 'ficha de candidatura' ser utilizado, para o INPI trata-se de formulário de pedido de

40 
registro. De acordo com um dos responsáveis pelas IGs na instituição, Raul Bittencourt Pedreira, em entrevista ${ }^{41}$, há uma justificativa: "Não tratamos como "candidaturas" pois não há subjetividade no ato, mas sim vinculação, sendo verificado se estão ou não presentes os requisitos legais dos tipos protegidos".

Primeiramente, é preciso explicar que neste trabalho optou-se por manter o uso do termo, por se entender que ele não implica, necessariamente, uma análise subjetiva no processo. Em segundo lugar, percebe-se uma diferença grande de abordagem nesse discurso. Enquanto as fichas e demais documentos do IPHAN expressam uma preocupação de que mesmo sistematizando haja flexibilidade para os diferentes tipos de documentos e fontes a embasarem os dossiês, partindo de metodologias da história, sociologia e antropologia, percebe-se um tratamento mais jurídico no processo do INPI, o que justificaria uma ficha de candidatura tão sucinta. Focaremos, assim, nos problemas de uso e função dessas fichas, como propõe Prior (2003), para apontar tais diferenças.

\section{SLOW FOOD}

A Arca do Gosto é um dos projetos desenvolvidos pela Fundação Slow Food pela Biodiversidade - um dos braços do movimento internacional. Trata-se, como já foi dito aqui, de um grande catálogo de produtos da diversidade natural e cultural do planeta. Apesar de ter iniciado em 1999 - mais ou menos na mesma época em que se definem as regras de registro do Patrimônio Cultural Imaterial Brasileiro e das Indicações Geográficas - esse inventário é parte de um conjunto maior de ações. Não se trata do grande projeto do Slow Food, mas é um dos mais importantes, aliado ao das Fortalezas e a outros que debateremos mais adiante.

Um ponto importante do discurso de intenções da Arca do Gosto foi a mudança pela qual o projeto passou no início de 2016.

\footnotetext{
Um novo formulário simplificado foi disponibilizado no website da Fundação Slow Food para a Biodiversidade, facilitando o processo de indicação, tornando-o mais rápido e fluido. [...] Com o aumento de indicações, a Arca, mais que um catálogo, passará a ser um arquivo em movimento, com um acervo de informações continuamente atualizado. Além de ter o papel crucial de preservar a memória da biodiversidade alimentar, a Arca é também um meio para motivar aqueles que, vendo reconhecido pela comunidade global um produto que marcou a sua infância, a paisagem e as pessoas ao seu redor, terão mais empenho em defendê-lo e preservá-lo. (SLOW FOOD BRASIL, 2016)
}

Essa mudança partiu da demanda por um processo mais célere na aprovação de candidaturas de novos produtos para a Arca. Assim, por mais que não haja mudanças nos critérios de seleção, há transformações nas etapas do processo para que ele se torne mais ágil -

\footnotetext{
${ }^{41}$ Entrevista feita por escrito, em 28 de setembro de 2016.
} 
exigindo-se menos aprofundamento na realidade do produto. $\mathrm{O}$ objetivo, explicam os responsáveis, é ampliar o número de produtos na catalogação, já garantindo alguma proteção para esses itens que estão em risco de extinção. A continuidade de ações de salvaguarda fica assim a encargo de outros projetos desenvolvidos pelo movimento.

Deve-se ressaltar que essa mudança no processo é recente e ainda ponto de debate dentro da rede Slow Food. Em fins de setembro de 2016, houve o Terra Madre e Salão do Gosto, encontro bianual de produtores, ativistas, cozinheiros e simpatizantes do movimento, em Turim, na Itália. Durante o evento, as discussões sobre as transformações já ocorridas e outras que talvez sejam necessárias foram intensas. Um dos pontos levantados pelo representante do Grupo de Trabalho (GT) da Arca do Gosto do Brasil, Jerônimo Villas-Bôas, durante o Fórum de discussão sobre o projeto, pode auxiliar-nos nessa análise:

Os números são importantes. Mas a partir do momento que se busca números, a gente corre um risco muito grande. E acreditamos que o Slow Food tem um compromisso enorme de comunicação de comunicar à sociedade [...] a coerência e a qualidade da informação que o catálogo proporciona. Seja ele um catálogo simples, seja ele um catálogo complexo, ele é um catálogo que precisa comunicar com coerência, com verdade. Biodiversidade é um tema complexo, que abrange aspectos sociológicos, biológicos, antropológicos, políticos e econômicos. Como comunicar isso num catálogo? A natureza dessa catalogação nos exigem contar uma história. Essa história vai ser contada de forma simples ou complexa, mas ela tem que ter começo, meio e fim. Tem que ser uma história bem contada. ${ }^{42}$

Retomando o conceito de Prior (2003) de que a análise de um documento vai muito além de seu conteúdo, mas deve abranger suas funções e usos, podemos analisar outros fatores ligados às intencionalidades do catálogo Arca do Gosto. No discurso de grande abrangência criado por um movimento que inclui de pequenos produtores a ativistas, de cozinheiros a acadêmicos, a linguagem é um obstáculo, conforme relatado. Mas vai além disso. Um dos desafios exposto por diversos atores do GT brasileiro tem sido a interpretação dos critérios para aceitação de um produto na Arca do Gosto, uma vez que estes foram criados numa realidade europeia diversa da nacional. São eles:

Um produto pode fazer parte da Arca do Gosto do Slow Food se...

...possui um valor alimentar. Os produtos da Arca podem ser espécies domésticas (variedades vegetais, ecótipos, raças e populações autóctones), espécies selvagens (somente se associadas a técnicas de coleta, transformação e usos tradicionais) ou produtos transformados.

\footnotetext{
${ }^{42}$ Discurso feito durante o Fórum da Arca do Gosto, realizado no dia 25 de setembro de 2016, em Turim, como parte da programação do Terra Madre/ Salão do Gosto.
} 
...é de qualidade (organoléptica ${ }^{43}$ ) particular. A qualidade é definida pelos costumes e tradições locais.

...está associado a um território, à memória, à identidade de uma comunidade e ao conhecimento tradicional local.

...é produzido em quantidade limitada.

...possui risco de extinção ou que tem a necessidade de ser reforçada para evitar o risco de desaparecer no futuro ${ }^{44}$

Um dos pontos de controvérsia é a definição de risco de extinção. Não se trata apenas de risco de extinção biológica: às vezes, uma espécie que está ameaçada em uma região é endêmica em outra do país ou do continente. Mas seu risco de desaparecimento naquela área traz consequências para a cultura alimentar local. Outra questão bastante debatida entre brasileiros e responsáveis da Fundação pela Biodiversidade do Slow Food Internacional é o que pode ser considerado um produto transformado. Assim como nos Livros de Registro do Patrimônio Cultural Imaterial Brasileiro do IPHAN, a Arca do Gosto não cataloga receitas de pratos.

Os membros do movimento no Brasil discordam da posição e tentam encontrar caminhos para que a as técnicas e práticas alimentares tradicionais do Brasil, sejam tão aceitas quanto as europeias. ${ }^{45}$ Afinal, o Slow Food e projetos como a Arca do Gosto foram, como vimos no capítulo anterior, essenciais para a construção de um turismo gastronômico sustentável na Itália, que se difundiu pela Europa. O fortalecimento das comunidades produtoras, detentoras de culturas singulares, foi o caminho que fez com que esse segmento turístico ganhasse nova conceituação. Nessa perspectiva, ao se adaptar à realidade brasileira e reconhecer as diferenças da cultura alimentar nacional, o movimento poderia desempenhar o mesmo papel inovador no turismo gastronômico do Brasil.

Conforme debatemos anteriormente, o empoderamento da população local apresenta-se como fundamental para que se possa ter um turismo que agregue e não colonize. Para tanto, é necessário valorizar os modos de fazer, os conhecimentos e tradições alimentares locais. E isso passa, necessariamente, pelo reconhecimento das diferenças entre as técnicas culinárias brasileiras e as europeias. Nesse sentido, se a catalogação do Slow Food tem um grande desafio

\footnotetext{
${ }^{43}$ Características organolépticas são aquelas que atuam sobre os sentidos: visão, olfato, tato, audição e paladar. Ou seja, um produto de qualidade organoléptica particular, é aquele que tem um sabor, um formato ou um aroma, por exemplo, específicos.

44 Disponível em http://www.fondazioneslowfood.com/en/what-we-do/the-ark-of-taste/nominations-fromaround-the-world/nominate-a-product/ficha-de-candidatura-para-a-arca-do-gosto/. Acessado em 01 out. 2016.

${ }^{45}$ Um dos exemplos dessa diferença foi levantado em reunião de Capacitação da Arca do Gosto e Fortalezas do Slow Food Brasil, realizada dia 23 de setembro de 2016, durante o Terra Madre/ Salone do Gusto, em Turim. A delegação do país questionou a representante da Fundação presente por que a carne de bode manteada, tradicional da Bahia, não foi aceita. A explicação é que, assim como o Barreado, receita regional paranaense, se tratam de pratos e não produtos. A diferença entre um e outro seria, ainda de acordo com a representante da Fundação, a capacidade de conservação: um produto é feito para se conservar, uma receita para ser consumida imediatamente.
} 
pela frente: ser capaz de abarcar esses saberes na Arca da Gosto, para este inventário possa servir de ferramenta na construção de um turismo alimentar brasileiro.

Ao analisarmos essa ficha sob a perspectiva proposta por Prior (2003) e Cellard (2012), para além do conteúdo, examinando quem são seus autores, seu público alvo, seu contexto, o que se percebe de diferente em relação às duas anteriores é que ela se torna um meio termo. É enxuta, quase como a do INPI, mas com objetivo de ser acessível - ao contrário daquela. A Arca do Gosto não pretende buscar a profundidade do Livro de Registros do IPHAN - adere mais aos números como forma de causar impacto e chamar atenção das pessoas para a biodiversidade que sustenta as culturas alimentares pelo mundo. $\mathrm{O}$ foco no mercado, mais perceptível nas IGs se encontra também no projeto Fortalezas, que é um aprofundamento da Arca - de pesquisa de produtores, tradições associadas e incentivos para que o produto possa se manter na cultura alimentar da comunidade em questão.

\subsubsection{Os Dossiês dos Bens Inventariados}

Uma vez analisadas as fichas de candidatura, ponto inicial ${ }^{46}$ de cada um dos três processos de inventariação que nos propusemos a discutir, passamos para a análise dos dossiês por elas gerados. Os documentos aqui selecionados foram compilados através dos sites das instituições (no caso do IPHAN e do Slow Food), de visita in loco com acesso aos processos físicos (no caso da sede do IPHAN, em Brasília) e online, via coordenação do projeto (no caso do $\left.\mathrm{INPI}^{47}\right)$.

Optou-se por fazer análise individual de cada dossiê, apresentando-as aqui divididas por instituições. Isso porquê ao examinar os dados sistematizados nas categorias (Fichas de Candidatura, Dossiês e Ações Extras), percebeu-se que, nesta, em particular, seria necessário criar uma subdivisão. Uma vez que nos propusemos a criar uma sistematização da análise documental flexível, baseada nos dados obtidos, como proposto por Cellard (2012), Prior (2003), Charmaz (2009), e Laville e Dionne (1999), definiu-se que, ao analisar tais documentos por instituição, poderíamos traçar um comparativo entre eles, estabelecendo um perfil mais

\footnotetext{
${ }^{46}$ Considerou-se neste trabalho as fichas como ponto inicial, mesmo que, para a candidatura, o responsável tenha que já haver levantado alguns dos dados. No caso do IPHAN, as fichas fazem parte do processo de inventário, ou seja, quando a candidatura do bem foi aceita e o Instituto então financiará o aprofundamento da pesquisa para registro do bem.

${ }^{47}$ Inicialmente, optou-se pela análise dos dossiês disponíveis online do INPI, que fazem parte de uma publicação feita em parceria com o SEBRAE, de 2014, chamada Indicações Geográficas Brasileiras. No entanto, por ter recebido a Indicação de Procedência apenas em fins daquele ano, a cajuína, um de nossos objetos de estudo, não foi incluída em tal publicação. Além disso, percebeu-se que os textos curtos da publicação em questão não seriam suficientes para uma análise fidedigna do processo, como se pretende com este trabalho. Por essa razão, foram examinados os dossiês completos, cujo acesso teve de ser demandado ao INPI.
} 
representativo de cada um dos três processos de inventariação aqui examinados. Após essa etapa, far-se-ão as comparações entre esses documentos - que foram selecionados exatamente por tratarem dos mesmos produtos e assim permitirem um confronto mais justo de suas diferenças.

\subsubsection{IPHAN}

Mesmo não tendo partido necessariamente da mesma metodologia, os três dossiês do IPHAN se assemelham em estrutura e temas abordados: identificação do bem; contexto territorial, social e histórico; mudanças e situação atual; possíveis ameaças e ações de salvaguarda. Observa-se também a pesquisa documental e bibliográfica, além de observações de campo, com entrevistas aos atores da cultura em questão. Percebe-se, então, a presença no texto final de quase a totalidade dos itens previstos nas fichas de identificação anteriormente analisadas. Até mesmo no dossiê da Cajuína, que não menciona a utilização do INRC como referência metodológica, nem possui as fichas do manual anexadas ao processo físico depositado na sede do Departamento de Patrimônio Imaterial (DPI) do IPHAN, em Brasília.

Também faz parte do processo de registro do IPHAN a produção de vídeos, uma para cada dossiê gerado. Os três aqui analisados são diversos entre si, mas apresentam, de uma forma ou de outra, um pequeno recorte do tema do documento escrito.

\section{Ofício das Baianas de Acarajé}

O dossiê do Ofício das Baianas de Acarajé é o mais antigo dos que analisaremos aqui. Ele foi inscrito no Livro dos Saberes em 10 de dezembro de $2004^{48}$. Desenvolvido pelo Centro Nacional de Folclore e Cultura Popular (CNFCP), através do Projeto Celebrações e Saberes da Cultura Popular, o processo de instrução do Ofício das Baianas de Acarajé "foi um projeto piloto desenvolvido pelo CNFCP para experimentar os instrumentos então criados para a salvaguarda do patrimônio imaterial; a saber: INRC e registro" ${ }^{\text {,4 }}$. Daí o nosso interesse em analisá-lo neste trabalho. Mesmo que seja um bem que não se repita nos outros dois inventários,

\footnotetext{
${ }^{48}$ A data de registro do bem não é unânime em todos os documentos analisados. Mesmo em textos do IPHAN e no próprio vídeo que faz parte do dossiê fala-se em janeiro de 2005. Entretanto, optou-se aqui por partir da data definida no documento de registro, $\quad$ disponível http://portal.iphan.gov.br/uploads/ckfinder/arquivos/BaianasdeAcarajeRegistro.pdf. Consultado em 02 out. 2016. A data coincide com a da Certidão de Registro, lavrada em 21 de dezembro de 2004. Disponível em http://portal.iphan.gov.br/uploads/ckfinder/arquivos/BaianasdeAcarajeCertidao.pdf. Consultado em 02 out. 2016. ${ }_{49}$ Ofício das Baianas de Acarajé. Disponível em http://portal.iphan.gov.br/pagina/detalhes/58. Consultado em 02 out. 2016.
} 
ele levantará questões pertinentes ao processo e até mesmo à restrição de sua presença nos outros dois métodos de catalogação ${ }^{50}$.

Outro ponto interessante a se destacar é a formatação do dossiê. Dos três bens registrados pelo IPHAN aqui analisados, este é o único cujo texto disponível online (aberto a quem tiver interesse, no site da instituição) tem uma diagramação artística, para impressão em formato de livro. A do Modo Artesanal de Fazer Queijo de Minas possui publicação semelhante, mas a que está disponível online no dossiê é mais simples. O fácil acesso ao documento, a formatação e a linguagem, tornam sua leitura fácil e interessante. Percebe-se uma preocupação de acessibilidade. Os textos são curtos, dinâmicos e bastante ilustrados - como é possível observar nas reproduções abaixo - sem que isso signifique que o dossiê se torne simplista.

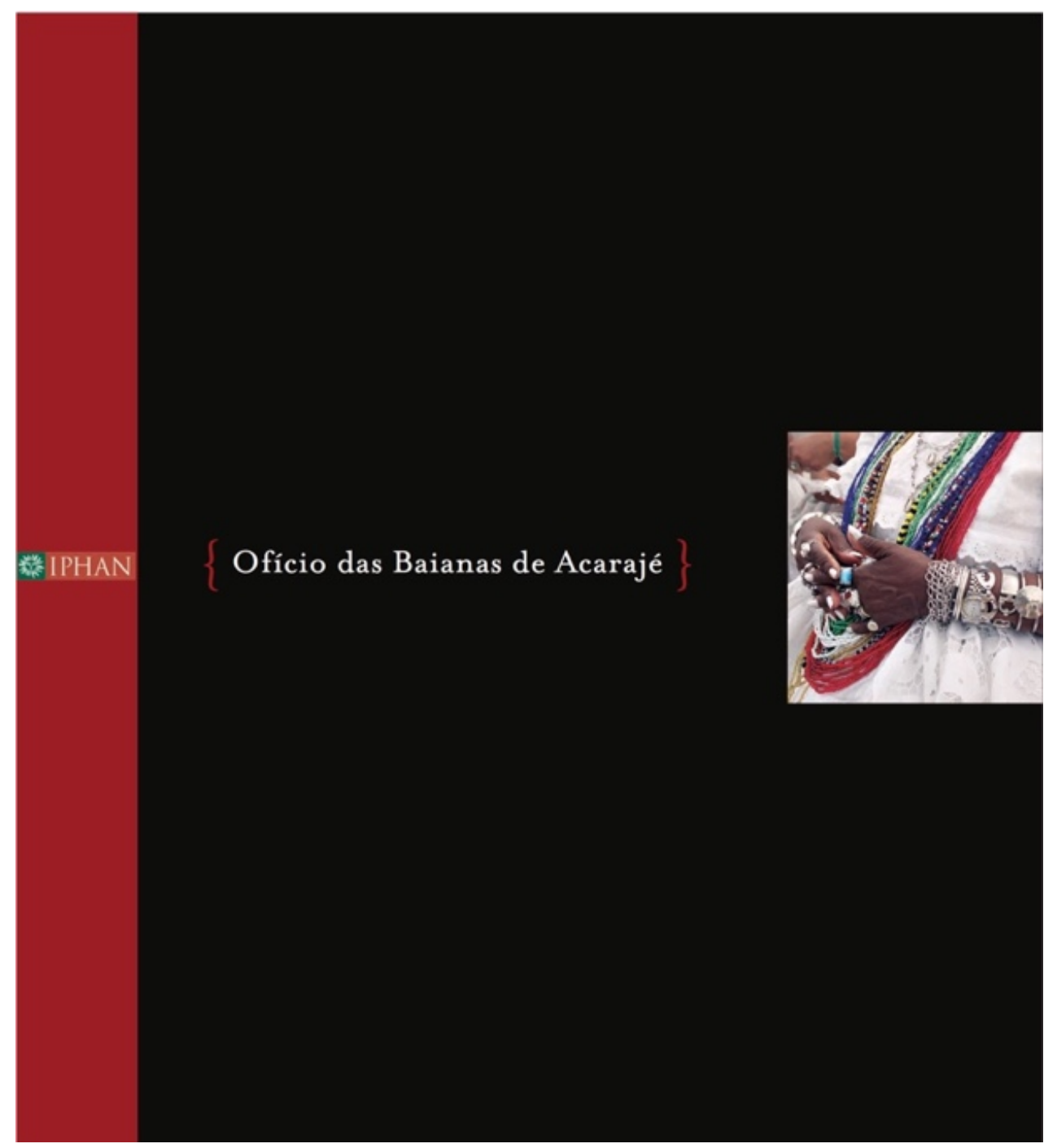

Figura 5. Reprodução da capa do dossiê do Ofício das Baianas de Acarajé, IPHAN.

\footnotetext{
${ }^{50}$ O Ofício das Baianas de Acarajé ou até mesmo o Acarajé não seriam passíveis de registro na Arca do Gosto, por não se enquadrarem na categoria de produto desenvolvida pelo Slow Food para a Catalogação. Além disso, o INPI nunca recebeu nenhum pedido de IG relacionado a esse preparo - que poderia enfrentar dificuldades para definir uma limitação geográfica.
} 
GANHO DE COMIDA, SECULO

Foтo: chaistiano 1 .

ou, ainda, de outras baianas, pois o ofício atualmente é organizado nos moldes de pequenas empresas domésticas e realiza-se como estratégia de sobrevivência ou de complementação de renda familiar.

Herdeiras dos ganhas, as baianas de tabuleiro, baianas de rua, baianas de acarajé ou simplesmente baianas, segundo o costume regional ${ }^{6}$, preservam receituários ancestrais africanos, sobretudo da costa ocidental, com destaque para os dos Iorubá. Verdadeiras construtoras do imaginário que identifica a cidade de Salvador - com suas comidas, sua indumentária, seus tabuleiros e suas maneiras de vender -, essas mulheres, monumentos vivos de Salvador e dos terreiros de candomblé, são um tipo consagrado, revelador da história da sociedade, da cultura e da religiosidade do povo baiano.

Ao estabelecerem elos entre os terreiros de candomblé e os espaços da

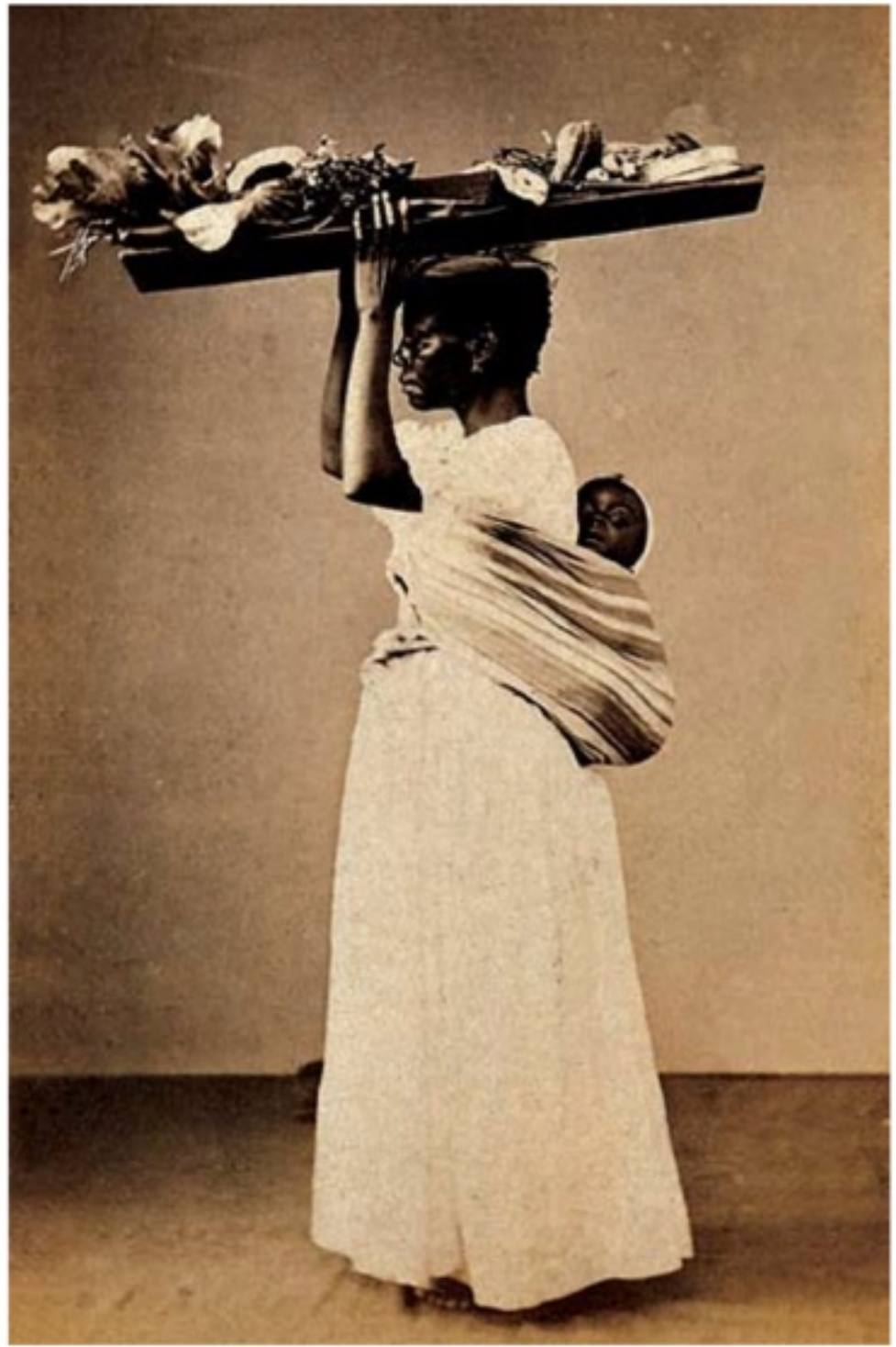

Figura 6. Reprodução de página do dossiê do Ofício das Baianas de Acarajé, IPHAN. 
Dez horas da noite na rua deserta.

A preta mercando parece um lamento...

(lê abará)

Na sua gamela tem molho cheiroso.

Pimenta-da-costa, tem acarajé.

(Ô acaraje eco olalai $\hat{o}-$

Vem benzêf-ê-em, tá quentinho.)

Todo mundo gasta de acarajé $O$ trabalho que da pra fazer é que é

Todo mundo gasta de acarajé

Todo mundo gosta de abará

Ninguém quer saber o trabalho que dá

Todo mundo gosta de abará

Dez horas da noite na rua deserta.

Quanto mais distante mais triste o lamento.

(lêt abará)

(Dorival Caymmi A preta do acaraje)
MODO DE FAZER E SIGNIFICADOS DOS PRIMEIROS ITENS

ALIMENTARES

TRADICIONAIS

QUE COMPÕEM 0

\section{ACARAJÉ}

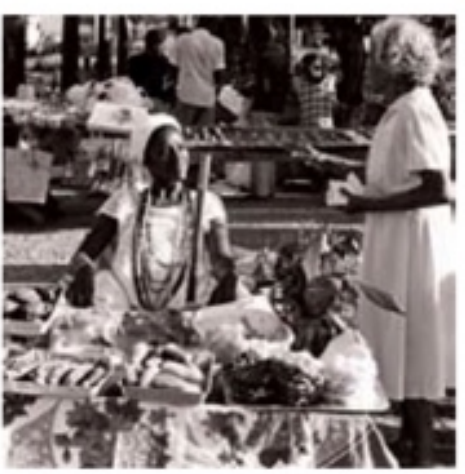

BAANA DE ACARAJE EM SEI

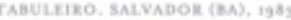

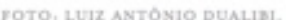

PAGINA AO LADO

DaIF TPNA DA

COYCHC

EEN LO FAES O FREFARO DA MASSA

DO ACARAIE I AMARA, SALVADOP

(BA) $x$ xoe:

goTO, RANCISCO MOREIRA DA

cosTA canção de Caymmi reafirma o 2 trabalho árduo de produzir e comercializar o acarajé. Durante muito tempo, seguindo a tradição dos terreiros e do período colonial, o feijão-fradinho, seu principal componente, era moido com um rolo cilindrico em pilão de pedra áspera $\mathrm{em}$ uma face; comercializado no formato de uma colher de sopa, em tabuleiros ou balaios levados na cabeça $^{10}$, era anunciado em pregões entoados pelas baianas.

Segundo Vivaldo da Costa (apud Miranda, 1998:17), a primeira descrição etnográfica dos modos de fazer acarajé é de Manoel Querino, no ensaio A Arte Culinária na Bahia, de 1916, publicado postumamente em 1928. Querino, "primeiro negro a publicar livros sobre a história e a cultura afrobrasileira", baseou sua pesquisa em depoimentos de "informantes conhecedoras da cozinha africana, tias

Figura 7. Reprodução de página do dossiê do Ofício das Baianas de Acarajé, IPHAN. 
DOSSIÊ IPHAN 6 \{ Ofício das Baianas de Acarajé\} 41

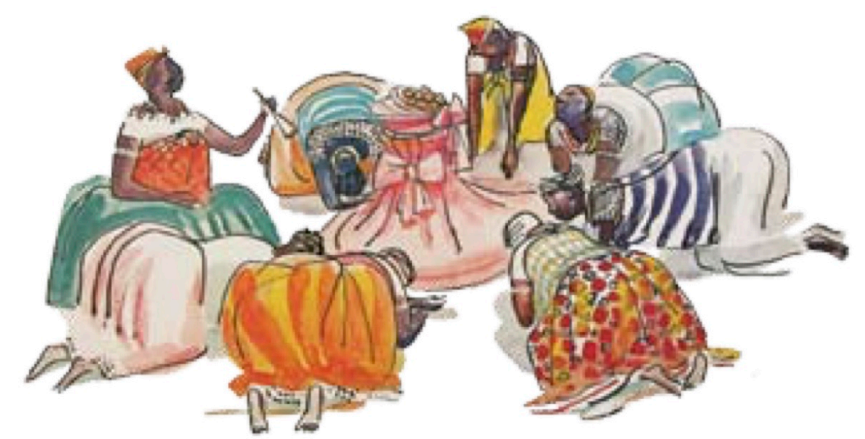

IANSÃ/SANTA BÁRBARA - A PADROEIRA DAS BAIANAS DE ACARAJÉ

Em "história narrada por Pai Cosme, um velho pai de santo da Bahia", no livro Orixás: deuses iorubás na África e no Novo Mundo (I997: I68), Pierre Verger descreve o orixá Iansã-Oiá (Oyá) que, na África, é

\footnotetext{
"divindade dos ventos, das tempestades e do Rio Níger que, em iorubá, chama-se Odò Oya. Foi a primeira mulher de Xangô e tinha um temperamento ardente e impetuoso. Conta uma lenda que Xangô enviou-a em missão na terra dos baribas, a fim de buscar um preparado que, uma vez ingerido, lhe permitiria lançar fogo e chamas pela boca e pelo nariz. Oiá, desobedecendo às instruções do esposo, experimentou esse preparado, tornando-se também capaz de
}

cuspir fogo, para grande desgosto de Xangô, que desejava guardar só para si esse terrível poder. Antes de se tornar mulher de Xangô, Oiá tinha vivido com Ogum. (...) Ela fugiu com Xangô e Ogum enfurecido, resolveu enfrentar o seu rival e lançou-se à perseguição dos fugitivos e trocou golpes de varas mágicas com a mulher infiel que foi então dividida em nove partes. Este número 9, ligado a Oiá, está na origem de seu nome Iansã (...) Esses nomes teriam por origem a expressão Aborimesan ("com nove cabeças"), alusão aos supostos nove braços do delta do Níger".

Segundo a liturgia católica, Santa Bárbara era uma jovem natural da cidade de Nicomédia de Bitínia, na Ásia Menor. Como era dona de uma beleza fora do comum, seu pai, enciumado, mandou trancá-la numa torre, para, assim, evitar a aproximação de qualquer pretendente. Durante uma viagem do pai, Bárbara pediu para ser batizada na fé cristã e, como na torre onde vivia existiam duas janelas, pediu que fosse aberta uma terceira, em homenagem à Santíssima Trindade. A atitude provocou a ira do pai e ela foi obrigada a fugir. Durante a fuga, os rochedos da torre abriram-se para que ela escapasse. Denunciada por um pastor, foi capturada, julgada e condenada a sofrer inúmeros suplícios, inclusive o de ser exibida nua por todo o país. Deus, compadecendo-se de sua sorte, vestiu-a com um manto vermelho. Depois dos castigos, foi executada por seu pai, que lhe cortou a cabeça com uma espada. Pouco depois de martirizá-la, ele morreu fulminado por um raio e, por causa disso, Santa Bárbara passou a ser invocada durante as tempestades.

Figura 8. Reprodução de página do dossiê do Ofício das Baianas de Acarajé, IPHAN.

O documento delineia como se constrói, historicamente, o ofício da Baiana de Acarajé. Para isso, faz uso de depoimentos de atores envolvidos - baianas, representantes religiosos e pesquisadores -, de referências culturais - como músicas de Dorival Caymmi - e de referências bibliográficas. Inicia traçando o surgimento do acarajé como comida dos orixás, parte integrante da cultura e ritualística do candomblé. É através da mítica de surgimento do "bolinho de fogo", comida de Xangô, preparada por Oxum e depois Oiá, que ele se torna um preparo fortemente ligado às mulheres. Assim, desenvolve-se a trajetória do acarajé como comida de santo para 
comida de gente e fonte de sustento. O texto explora ainda a ligação do ofício com a Feira de São Joaquim, onde as baianas adquirem todos os ingredientes necessários para o preparo. Passase então a uma descrição do modo de fazer e ao significado dos principais itens que compõem o acarajé.

Os trajes das baianas também são detalhadamente apresentados, aprofundando no significado de cada peça da indumentária, assim como a relação do ofício com as festas de Largo e a festa de Santa Bárbara, padroeira das Baianas de Acarajé. Todos esses elementos fazem parte da identificação do objeto do dossiê. É interessante notar o quão próximo eles são dos itens da ficha 60, de identificação de ofícios, do INRC. Sabendo se tratar de um dos primeiros processos de instrução (etapa de pesquisa de campo mais aprofundada) a utilizar-se dessa ferramenta, fica claro que os parâmetros à época definidos se ajustaram de forma satisfatória para essa pesquisa. O resultado é um dossiê conciso sem deixar de ser profundo.

O texto ainda trata da realidade do ofício na contemporaneidade, com todas as mudanças trazidas pela modernização dos equipamentos, o consequente crescimento do comércio e o aumento de atores desconectados da cultura originária do acarajé exercendo o ofício de baiana. Fenômeno bastante relevante é a entrada de homens no ofício antes considerado apenas feminino; de evangélicas (os) que tentam se desvencilhar das origens afro, renomeando o tradicional bolinho de "Acarajé de Jesus"; e das indústrias que passam a subcontratar as baianas e levam o acarajé do tabuleiro para a prateleira dos supermercados.

Esses são os principais pontos destacados pelo dossiê para que se alimente o debate de como salvaguardar o Ofício das Baianas do Acarajé. O documento mostra a complexidade do tema, a dificuldade de se proteger um bem imaterial, em processo constante de ressignificação. Ao mesmo tempo, o discurso é bastante claro de que, o ofício em questão nasce na cultura religiosa africana, no candomblé, e isso deve ser elemento presente em sua prática.

Já o vídeo, que integra o dossiê é curto e pouco estruturado: traz trechos de entrevistas dos atores envolvidos com o bem, sem construir uma narrativa coesa nos seus quase cinco minutos de duração.

\section{Modo Artesanal de Fazer Queijo de Minas}

Inscrito no Livro de Registro dos Saberes em 13 de junho de 2008, o dossiê interpretativo do Modo Artesanal de Fazer Queijo de Minas abrange três territórios diferentes registrados: o Serro, a Canastra e o Salitre ou Alto Paranaíba. O texto, com linguagem acessível, mesmo que por vezes técnica ou acadêmica, é disponibilizado no site do IPHAN em formato digital - diagramado como publicação mais próximo do modelo acadêmico, como pode ser observado nas figuras 9 e 10 . No entanto, há uma versão em formato didático como o do Ofício 
das Baianas do Acarajé, do Modo Artesanal de Fazer Queijo de Minas. Ele foi lançado em 2014, e é $11^{\circ}$ volume da Coleção Dossiê dos Bens Culturais Registrados do IPHAN.

Esta última publicação tem por objetivo tornar o conteúdo do dossiê mais acessível, conforme explica a presidente do Instituto à época, Jurema Machado, na sua apresentação:

A Coleção Dossiê dos Bens Culturais Registrados destina-se a tornar
amplamente conhecidos e valorizados, como patrimônio cultural do Brasil, os
bens registrados de natureza imaterial. Os dossiês têm por base os estudos que
fundamentaram o registro do bem cultural e refletem as etapas de pesquisa,
análise e reconhecimento desse patrimônio.
[...]
A divulgação dos processos de registro e dos resultados do trabalho
institucional contribui para a extensão do reconhecimento desse patrimônio
pela sociedade brasileira e favorece as condições de sua permanência. São
apresentados nos dossiês elementos que definem a identidade dos bens
culturais, seu universo de ocorrência, os grupos sociais envolvidos e as
práticas e saberes a eles inerentes. (BRASIL, 2014b, p. 11)

Essa versão está disponível no site do IPHAN também, porém não junto com os documentos referentes ao Modo Artesanal de Fazer Queijo de Minas. É possível encontrá-la entre todas as publicações abertas do Instituto. Por essa razão, optou-se por analisar aqui a versão mais acadêmica, que é a que está disponível com o restante dos documentos que formam o dossiê de registro. No entanto, vale registrar que o documento de 2014 traz uma diagramação muito mais interessante, mas que o texto, mesmo que diferente, com outra organização, não é tão distante. É uma publicação mais acessível, ainda que em alguns momentos, o texto se torne um pouco acadêmico.

Integra ainda o dossiê um documentário de 30 minutos. Bem estruturado, ele contém muito mais do que apenas testemunhos (como no das Baianas de Acarajé), mas narra a trajetória do queijo na região. Conta com falas de produtores, vendedores, técnicos da EMATER, professores da UFMG, e um integrante do movimento Slow Food - Homero Vianna - que relatam a importância do modo de fazer queijo na construção da cultura da população daquela região. Quanto ao uso do INRC, percebe-se ainda, como no inventário anterior, uma correlação das questões presentes nas fichas do manual com o dossiê apresentado. Entretanto, já há uma grande diferença de abordagem - que pode ocorrer por se tratarem de um ofício e um modo de fazer (mesmo que ambos correspondam à Ficha 60).

O texto do dossiê propõe-se a debruçar sobre a complexidade do registro de bens de natureza imaterial e apresenta as dificuldades de se refletir sobre um modo de fazer que ainda é cotidiano, mas, ao mesmo tempo, está sendo ameaçado pelas regras sanitárias e pela celeridade dos tempos atuais que traz a sensação de perda das tradições - discussão que já apresentamos neste trabalho. O discurso presente ao longo de todo o dossiê é muito mais crítico 
às mudanças e ameaças que o bem em questão vem sofrendo. E se apresenta ao longo de todo o texto. Os debates que se repetem ao redor do mundo sobre a proteção de queijos artesanais de leite cru são introduzidos já no início.

\section{Queijo Artesanal de Minas}

Patrimônio Cultural do Brasil

Dossiê Interpretativo 
dos momentos e ao descrever a Província de Minas Gerais, a compara à de Goiás e a de Mato Grosso, dizendo-a "mais feliz" que aquelas. Segundo ele, "esta provincia vê a indústria aumentar os recursos da natureza." E, além de outras riquezas, "dedica-se à criação de aves e animais, abastece de queijo o Rio de Janeiro e possui fábricas de tecidos, chapéus e roupas brancas.."11

Ao relatar e pintar negros vendedores de leite na cidade do Rio de Janeiro, fala do costume de se consumir leite cru e da negligência em não produzir manteiga e outros laticínios. Conclui que "os únicos queijos do país vêm de São Paulo e de Minas Gerais". ${ }^{12}$ Debret fala de um tempo em que passou no Brasil, 15 anos, de 1816 a 1831.

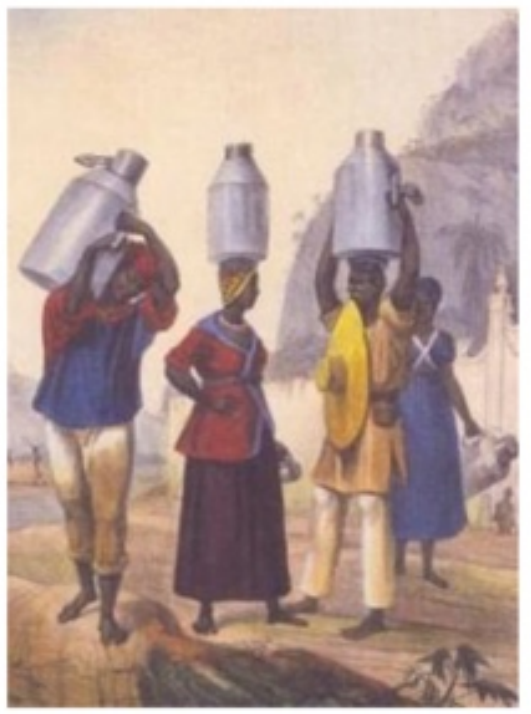

Debret representa em aquarela de 1816 a utilizaçăo do leite cru e seu comércio usando mâo-de-obra escrava, ao final do período colonial.

Tais exemplos documentais distintos nos permitem leituras que denotam a tradição do saber-fazer esse produto artesanal no cotidiano de produtores

${ }^{11}$ DEBRET, Viagem pitoresca e histórica ao Brasil, p. 135. Negrito nosso.

${ }^{12}$ DEBRET, Viagem pitoresca e histórica ao Brasil, p. 223. 
Aqui, inclusive, vale destacar outro ponto deste dossiê - que se repetirá nas ações de salvaguarda do mesmo bem: há um diálogo entre o IPHAN e outra instituição aqui pesquisada, o Slow Food. Tanto o discurso do Instituto do Patrimônio Histórico e Artístico Nacional como o de grupos de trabalho do movimento internacional se alinham nesse tema: "O movimento Slow Food realiza desde o ano 2000, uma campanha de proteção aos produtores de queijo de leite cru, defendendo os seus direitos de produzir o queijo frente à leis higiênico-sanitárias demasiado tecnicistas que dificultam a sua produção" (BRASIL, 2006, p. 16).

Traça-se então um histórico da produção de queijo na região de Minas Gerais. A técnica, nascida na Serra da Estrela, em Portugal, que se adapta à realidade brasileira; as diferenças entre cada região... O texto ainda destaca a importância do queijo na alimentação da população local e como ele está atrelado a uma economia diversa, não podendo se falar em "ciclo do queijo" como se fosse algo com tempo determinado (BRASIL, 2006, p. 19). Diferentes fontes documentais históricas são utilizadas para reforçar o discurso de que o queijo se integrou ao sistema culinário da região desde os tempos da colonização.

Por se tratar do registro de um Modo de Fazer, o documento traz também descrições das diversas técnicas utilizadas historicamente na confecção dos queijos, suas similitudes e mudanças ao longo do tempo. Nota-se um discurso entre o nostálgico e o combativo a algumas das mudanças que o processo de fabricação do queijo teve que passar por imposição das atuais regras sanitárias do país. Como no trecho abaixo:

Atualmente é rara a utilização da madeira nas bancas e as formas de madeira deixaram de ser usadas há muitos anos. Elas guardam a memória de um fazer tradicional e são objetos que documentam essa identidade da fazenda mineira e do fazendeiro das Minas, em museus, centros de memória, hotéis, restaurantes, centros de recepção turísticos e casas mineiras. São símbolos, são emblemas de uma ruralidade que permanece em padrões tradicionais e em dinâmica transformação.

Utilizam-se, em nossos dias, bancas de pedra ardósia e formas plásticas, materiais de fácil higienização. A dinâmica da tradição reflete, mesmo que lentamente, as mudanças de concepções técnicas, de padrões de higiene e de valores culturais (BRASIL, 2006, pp. 29-30).

Baseado em estudos desenvolvidos pela UFMG e pela EMATER, o dossiê interpretativo do IPHAN descreve as três regiões registradas (Serro, Canastra e Salitre ou Alto Paranaíba) e suas particularidades no Modo de Fazer o queijo artesanal. 


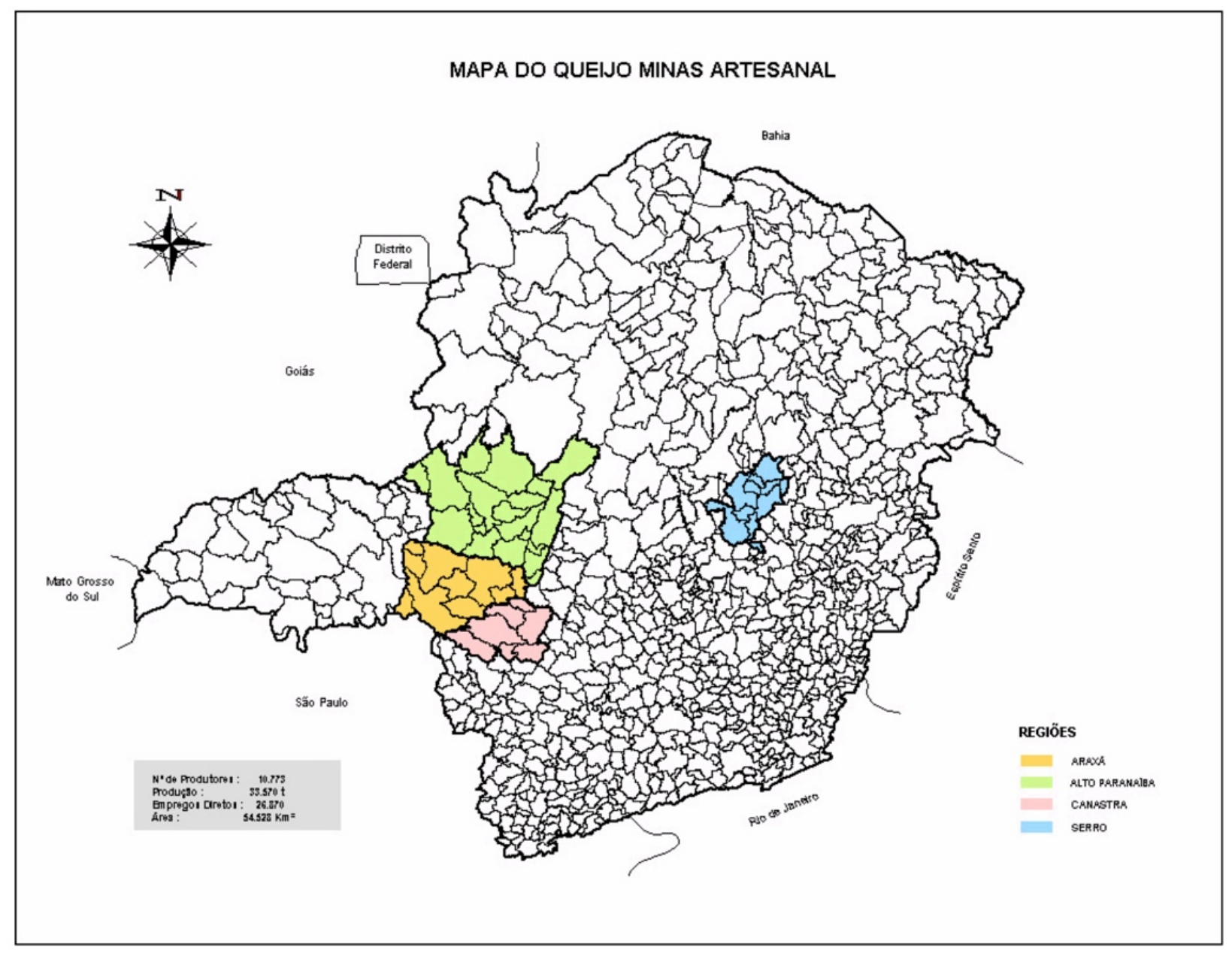

Figura 11. Mapa do Queijo Minas Artesanal. Fonte: IPHAN, 2006, p.40.

A sociabilidade que o fazer o queijo traz e a culinária em torno dele também são abordados no texto, ressaltando o papel do modo de fazer na formação da memória e identidade local. As entrevistas de campo apresentadas enriquecem bastante esse trecho do dossiê. Este se encerra destacando o valor cultural, econômico e social que o queijo tem nessas regiões e propõe algumas ações de salvaguarda a serem desenvolvidas, que apresentamos aqui a título de comparação com os inventários a serem analisados adiante:

Os instrumentos de salvaguarda, considerando o modelo de território do queijo artesanal de Minas devem:

- desenvolver um sentimento de pertencimento do grupo ao patrimônio e de afirmação da identidade local por parte dos habitantes da região;

- construir uma imagem que singulariza o produto e convida a conhecer o seu território;

- criar instrumentos de informação que sejam foco de atração para se conhecer e consumir o produto;

- potencializar comercialmente o produto cultural reconhecido. (BRASIL, 2006, p. 80)

Faz necessário ainda destacar a detecção de diversos grupos organizados locais, como cooperativas, associações e até mesmo a EMATER (empresa pública) interessados em 
salvaguardar e valorizar esse patrimônio. Aprofundaremos essa discussão ao comparar os três processos de inventariação relacionados aos queijos artesanais de Minas.

\section{Produção Tradicional e Práticas Socioculturais Associadas à Cajuína no Piauí}

O mais recente dos três bens aqui analisados, a Produção Tradicional e Práticas Socioculturais Associadas à Cajuína no Piauí foi inscrita no Livro de Registro dos Saberes em 15 de maio de 2014. É interessante ressaltar que o pedido inicial de registro era do "Modo de Fazer da Cajuína”, mas a Câmara do Patrimônio Imaterial, em 2008, pediu para que o recorte fosse ampliado, abrangendo saberes e fazeres tradicionais relacionados ao complexo cultural do caju.

Isso talvez explique o extenso histórico da formação da região, presente no dossiê final. O formato deste dossiê é o mais próximo do acadêmico (vide figuras 12 e 13). É também o único dos três que não cita ser referenciado no INRC nem contém em seu processo físico nenhuma ficha do manual. É também o mais longo de todos - o que torna sua leitura pouco acessível para um grande público.

O vídeo que integra este dossiê é igualmente diferente dos demais: ele não trata do contexto histórico ou social, apenas mostra o diretor da Cooperativa de cajuína do Piauí Cajuína Cristalina Teresina do Piauí, Lenildo Lima, ensinando a preparar a bebida tradicional. Alguns questionamentos podem ser feitos sobre essa escolha. Percebe-se a intencionalidade de mostrar o processo de feitura da cajuína. Entretanto, para isso, mostra-se uma pessoa preparando uma pequena quantidade (claramente apenas para o vídeo), sozinha, ao contrário do que o dossiê narra ser o modo de fazer local, utilizando-se de cajus congelados e de um liquidificador - também diferente da prática que se registra. Ou seja, esse documento audiovisual torna-se um "vídeo de receita" apenas, contradizendo vários dos valores tradicionais associados à produção da cajuína, defendidos no dossiê escrito.

Este por sua vez, falhe, talvez, pela razão oposta: é muito extenso. O texto descreve a importância da cajuína como bebida identitária do piauiense, sua produção familiar e seu caráter de bebida comemorativa - a ser degustada. Outro ponto que chama a atenção no dossiê é se tratar aqui de um bem que pertence às elites locais: "em especial as camadas de proprietários de terra e funcionários públicos ou empresários com maior nível de renda" (BRASIL, 2009, p. 14). O documento aponta que, apesar de os atores envolvidos considerarem a cajuína como uma bebida de tradição antiga, não há registros e as entrevistas não puderam traçar sua produção no Piauí antes do século passado. Trata-se, assim, de um fenômeno recente, de elite, que foi sendo apropriado pelas populações de outros estratos sociais nas últimas décadas. 
INSTITUTO DO PATRIMÔNIO HISTÓRICO E ARTÍSTICO NACIONAL

"PRODUÇÃO ARTESANAL E PRÁTICAS SOCIOCULTURAIS ASSOCIADAS À CAJUÍNA NO PIAUUi”

Periodo de Trabalho

outubro 2008 - setembro 2009

Figura 12. Reprodução da capa do dossiê Produção Artesanal e Práticas Socioculturais Associadas à Cajuína no Piauí, IPHAN. 
$\mathrm{Na}$ hospitalidade comercial, o acolhimento, mesmo no âmbito comercial, efetiva-se na relação hóspede/anfitrião da mesma forma que na doméstica, uma vez que é uma extensão desta. Para Anne Gotman, na hospitalidade comercial a dádiva é substituida pelo devido por meio do preço combinado, tornando-se a principal referência para o sistema comercial, seja como metáfora, seja como mise en scène (encenação) da hospitalidade. Assim, "o gesto humano se impõe ao gesto comercial mecânico e cria sociabilidade" ${ }^{98}$ Esse cenário também é repleto de conflitos, já que lida com seu inverso que é a hostilidade, quando alguma regra do ritual não foi respeitada. Isso ocorre porque as regras do ritual continuam as mesmas, com suas variações no tempo e no espaço - e ai está a denotação da presença da verdadeira hospitalidade (apud CAMARGO, 2007).

Mais recentemente, com a produção da cajuina estimulada pelo mercado, observamos que é sua condição de componente de hospitalidade doméstica que lhe confere valor, intensificando sua condição de bem que simboliza um sistema de dádiva: dar, receber e retribuir.

Figura 17 - Cajuina - sem rótulo - para consumo familiar.

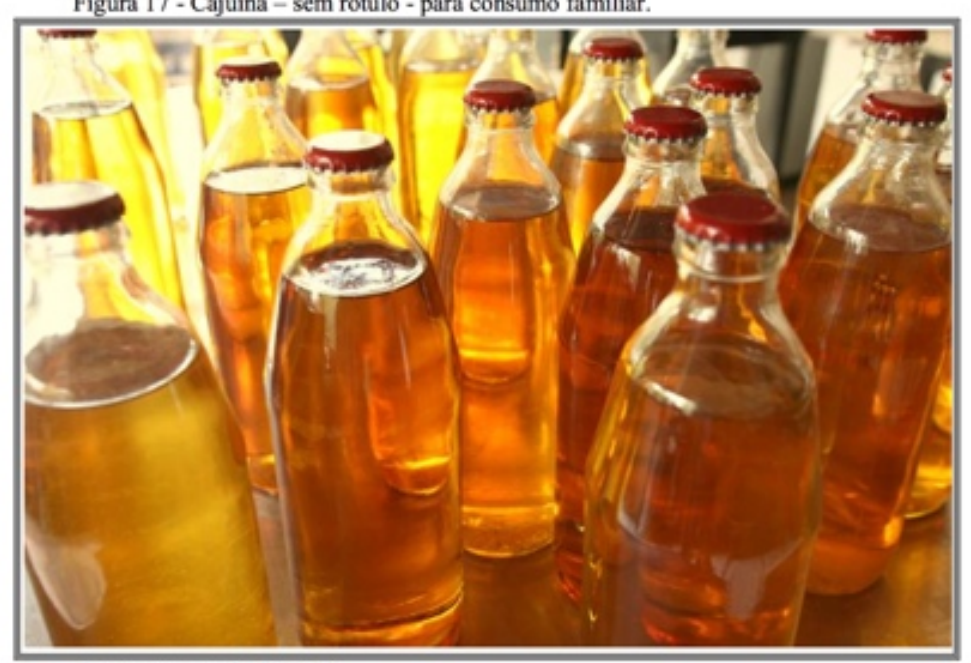

Fonte: Acervo do IPHAN.

\footnotetext{
${ }^{98} \mathrm{O}$ ritual de recepç̃o turística guarda, pois, uma interface fundamental com a hospitalidade, como sua encenaçĩo. Da mesma forma, as inovações na área da gestão - fidelização, customização, responsabilidade social etc. acabam por restabelecer o gesto da reciprocidade e a dádiva tornando o contrato uma encenação.
}

Figura 13. Reprodução de página do dossiê Produção Artesanal e Práticas Socioculturais Associadas à Cajuína no Piauí, IPHAN.

As origens da bebida são de difícil definição, aponta a pesquisa. Há quem reivindique que o "inventor" da cajuína foi um médico farmacêutico do Ceará, Rodolfo Teófilo, que teria 
aplicado o método Appert de pasteurização à água de caju e registrou o nome da cajuína na última década do século XIX. Há também investigações que conectam a cajuína ao vinho de caju, esse popular entre as camadas mais simples, e bastante alcóolico. A sua origem seria o mocororó ou cauim, bebidas de caju fermentadas indígenas. Entretanto, não haveria uma continuidade entre essas tradições, ao contrário.

Na realidade, não acreditamos que se deva buscar uma linha de continuidade entre a bebida tradicional e fermentada e o refresco passível de ser armazenado. Pelo contrário, talvez devamos nos ater à ruptura e ao elemento de superação que existe entre os dois, para entendermos o significado da cajuína. Isso nos parece indicativo de um processo de consolidação de uma identidade, que se dá através do apascentamento dos conflitos e embates violentos que se deram no processo de colonização do Piauí. Para entendermos como os significados e simbolismos de limpeza, pureza, cristalinidade e conforto que encontramos nos sentidos atribuídos à cajuína vicejam tão rapidamente em um solo cultural fértil para a sua aceitação, precisamos entender o passado que se abandona e transforma, em que sentido o futuro se delineia, qual o perigo do qual essa sociedade se distancia (DOUGLAS, 1966 apud BRASIL, 2009, p. 90).

O dossiê se detém longamente na construção histórica da elite piauiense, desde o Brasil colônia e a formação do território. Assim como nos fatores que levaram o estado a ser o que mais dizimou índios no país. A cajuína, aponta o texto, representa a hospitalidade dessa sociedade piauiense "civilizada". É produzida e servida por "senhoras da alta sociedade", considerada a champagne do Piauí. Uma tradição dominada por mulheres, que correspondiam ao ideal de "mulher prendada", que não deixava nada se perder em casa e que vai passando de geração para geração - mas também de patroa a empregados (que são muitas vezes quem produz a cajuína) e esses a seus filhos, parentes e vizinhos. Além da cajuína, preparava-se uma série de doces, bolos e biscoitos com o caju.

O texto ainda aponta as mudanças sofridas pelo modo de fazer a bebida ao longo do tempo, com a mecanização e a substituição da resina do cajueiro pela cola de sapateiro e, atualmente, pela gelatina. Introduz-se também os novos atores da produção do bem registrado. Pequenos produtores rurais, muitos de assentamentos, que tomaram contato com a bebida através de treinamentos do SEBRAE e que só produzem, mas não são consumidores da cajuína.

Além disso, aponta como grande risco para o modo de fazer artesanal os investimentos que vêm sendo feitos para tornar a cajuína um "produto exportação". Critica fortemente também a ação do SEBRAE junto à EMBRAPA, que pretende padronizar o modo de fazer, modificando as regras para adequar à legislação sanitária, acelerando a filtragem e utilizando cajus clonados. Detemo-nos um pouco nesse ponto pois ele nos subsidiará para a discussão de diferenças de abordagens dos inventários aqui analisados: 
A produção da cajuína, no momento atual, possui grande potencial gerador de renda e divisas para o Estado, descoberto e impulsionado pela ação das instituições mencionadas. Isto ocasiona vários benefícios e algumas ameaças à integridade cultural do bem em questão. A principal ameaça consiste justamente no esforço que o SEBRAE despende no sentido da padronização da bebida, de forma a atender aos requisitos da Certificação de Origem Geográfica. Por esse processo, a cajuína, reconhecida como a verdadeira cajuína piauiense, teria a mesma cor, teor de açúcar e sabor. Para tanto, deverá ser feita a partir do caju clonado, uma das variedades desenvolvidas pela EMBRAPA. Isso acarretaria no segundo risco, ambiental; ou seja, criar-se uma situação que faria com que cajuais nativos fossem preteridos em função dos cajuais clonados, o que causaria impacto sobre a biodiversidade local. (BRASIL, 2009, p. 188)

Ao encerrar a análise desses três dossiês do IPHAN, percebe-se que mesmo que eles abranjam temáticas semelhantes, partindo ou não da metodologia do INRC, terminam por ter formatos completamente diversos. O que implica em públicos também distintos. Os processos de registro são demandados por associações que sentem que seu ofício ou modo de fazer está ameaçado. São anos de processo de pesquisa ${ }^{51}$ para construir todo o contexto e justificativa para que tal bem seja inscrito em um dos livros de registro do Patrimônio Cultural Imaterial Brasileiro. Mas, mesmo que as intencionalidades se assemelhem - salvaguardar a prática em questão - o público atingido com esses documentos pode ser completamente diferente.

Os textos e vídeos que compõe os dossiês aqui analisados são exemplo exato dessa diversidade: enquanto a publicação escrita do Ofício das Baianas de Acarajé é atrativa e didática, aprofundando sem perder o foco, a da Produção Tradicional e Práticas Socioculturais Associadas à Cajuína no Piauí é muito longa e se perde um pouco ao traçar o histórico da formação do território e suas elites. Já a do Modo Artesanal de Fazer Queijo de Minas fica entre os dois - não é tão concisa e didática quanto o primeiro, mas nem tão extensa quanto o segundo. Por outro lado, os vídeos são, de certa forma, desvinculados dos textos. Se o do Modo Artesanal de Fazer Queijo de Minas tem uma narrativa coerente completa, podendo ser considerado um documentário fiel ao dossiê, o do Ofício das Baianas de Acarajé apenas reproduz trechos de entrevistas, e o da Produção Tradicional e Práticas Socioculturais Associadas à Cajuína no Piauí acaba por ser um "vídeo de receita", que até mesmo contradiz o texto do dossiê ao apresentar algo fora da tradição da prática social do fazer a cajuína.

Ao observar a diversidade de materiais que o inventário do IPHAN apresenta, pode-se dizer que, mesmo criando uma metodologia de sistematização, ele permite produtos finais que

\footnotetext{
${ }^{51}$ Em geral, entre o pedido de registro e a inscrição do bem em um dos livros do IPHAN, leva-se, em média, de sete a oito anos. Exceção foi o Ofício das Baianas de Acarajé, que já tinha um projeto estruturado de pesquisa, e levou apenas dois anos entre o pedido e reconhecimento oficial do ofício como patrimônio imaterial nacional.
} 
respeitem as diferenças do processo de construção e atores envolvidos nele. No entanto, quando se parte do discurso de registrar um patrimônio cultural imaterial a fim de salvaguardá-lo, talvez seja fundamental pensar em dossiês escritos mais didáticos, que possam ser utilizados em projetos de educação patrimonial e que sejam mais acessíveis aos atores principais desses bens. Dessa forma, se poderá construir uma base para a valorização turística de tal bem de forma equilibrada. Ao empoderar a população local com seu próprio patrimônio cultural, o turismo passa a ser uma ferramenta de desenvolvimento e não de colonização. A mesma premissa vale para vídeos cativantes, que contem a história do dossiê com uma narrativa bem construída. E para isso formatos um pouco mais padronizados podem ser de valia.

\subsubsection{INPI}

Durante a nossa primeira fase de pesquisa documental havíamos optado por analisar os dossiês do INPI publicados em parceria com o SEBRAE em 2014, no livro de título Indicações Geográficas Brasileiras, disponível online. A acessibilidade havia sido o fator em comum com os demais documentos aqui examinados levado em conta. Entretanto, duas questões nos levaram a alterar nossos objetos de análise: a primeira foi que, por ter recebido a Indicação de Procedência apenas em fins daquele ano, a cajuína, um de nossos objetos de estudo, não foi incluída em tal publicação; a segunda, e mais relevante, foi a percepção de que os textos curtos do livro não seriam suficientes para uma análise fidedigna do processo de inventariação desenvolvido pela instituição, como se pretende aqui. Dessa forma, após consulta ao INPI, que se dispôs a liberar o acesso à documentação em questão por se tratar de pesquisa acadêmica, optou-se por examinar os dossiês completos.

Os dossiês do INPI diferem bastante dos demais aqui analisados. Como já apontado na análise das fichas de candidatura, há no discurso da instituição uma intencionalidade de objetividade e uma abordagem jurídica. Por conta disso, os documentos têm uma estrutura bastante restrita pela ficha de candidatura. Tratam-se, assim, de conjuntos de documentações necessárias para a obtenção da certificação de IG. Não são textos construídos com uma lógica única, como nos demais dossiês aqui analisados, mas compêndios de documentos avulsos. Esse formato pode gerar, portanto, uma certa desorganização das informações. Por outro lado, ele faz com que os dossiês finais sejam bastante semelhantes entre si.

É válido ressaltar ainda que há, no Brasil, dois tipos de Indicações Geográficas, a Indicação de Procedência (IP) e a Denominação de Origem (DO). Neste trabalho, optou-se por seguir analisando os produtos que coincidem nos três processos de inventariação. Por essa razão, não se tratou aqui de nenhuma certificação de DO. Além disso, entendeu-se que tal 
exame não seria essencial às reflexões, uma vez que o processo é idêntico ao das IPs, apenas com a exigência de documentos extras que comprovem "Elementos que visam descrever as qualidades e características do produto ou do serviço que se devam, exclusiva ou essencialmente, ao meio geográfico, incluindo os fatores naturais e humanos" e "Elementos que visam descrever o processo ou método de obtenção do produto ou do serviço, que devem ser locais, leais e constantes" ${ }^{\prime 52}$ - sendo que este último, mesmo não sendo obrigatório, está presente nos dossiês aqui analisados.

\section{Serro - Queijo}

O dossiê, de 437 páginas, divididas em dois volumes, registra todo o processo de estabelecimento da Indicação de Procedência. Desde a identificação do Pedido de Registro de Indicação Geográfica, neste caso enviado em 03 de março de 2010, pela APAQS - Associação dos Produtores Artesanais de Queijo do Serro - e protocolado em 16 de abril do mesmo ano. Trata-se, como foi dito, de uma coleção de documentos. Estes são bastante variados e vão desde lista de produtores associados à APAQS, com cópias de Notas Fiscais dos mesmos, ao Regulamento de Uso da Indicação de Procedência Serro para o Queijo Minas Artesanal e Atas da APAQS - nestas relatam-se as decisões de composição da diretoria, alterações em artigos específicos do Estatuto Social da Associação e análise e aprovação do Regulamento de Uso para Indicação de Procedência Serro para o Queijo Minas Artesanal.

Percebe-se, portanto, que a linguagem e apresentação são adequadas ao público alvo dessa compilação: advogados responsáveis por verificar que toda a documentação condiz com as exigências do INPI para a concessão da Indicação Geográfica. Um exemplo da rigidez do processo é o da etiqueta de Indicação de Procedência do Serro. O formulário de pedido de registro, primeiro documento que compõe o dossiê, tem um pequeno espaço reservado à etiqueta. No entanto, ao apresentar a candidatura, a APAQS não exibiu a figura neste local, apontando o modelo, que reproduzimos abaixo, no documento seguinte. Por conta disso, o processo não foi aprovado de primeira análise e a associação teve de reenviar o formulário em questão com a figura no local correto.

Os regulamentos de uso da IP fazem parte da documentação obrigatória e devem precisar algumas informações como a delimitação da área geográfica da IP, as matérias primas utilizadas para a produção do bem em questão - no caso do Queijo Artesanal do Serro, por exemplo, ele define não apenas o tipo de leite, coalho, pingo e sal que devem ser usados, mas até mesmo o rebanho (que deve corresponder aos cruzamentos de bovinos das espécies Bos

\footnotetext{
${ }^{52}$ Itens do formulário "Pedido de Registro de Indicação Geográfica”. Disponível em http://www.inpi.gov.br/menuservicos/downloads-de-formularios-para-pedidos-protocolados-em-papel-no-inpi. Consultado em 25 out. 2016.
} 
taurus e Bos indicus). A alimentação do rebanho, as pastagens, as características organolépticas e físico-químicas do produto, tudo é especificado. As regras sanitárias vigentes no país também são reafirmadas - tanto nos regulamentos de uso, como com a legislação correspondente em anexo.

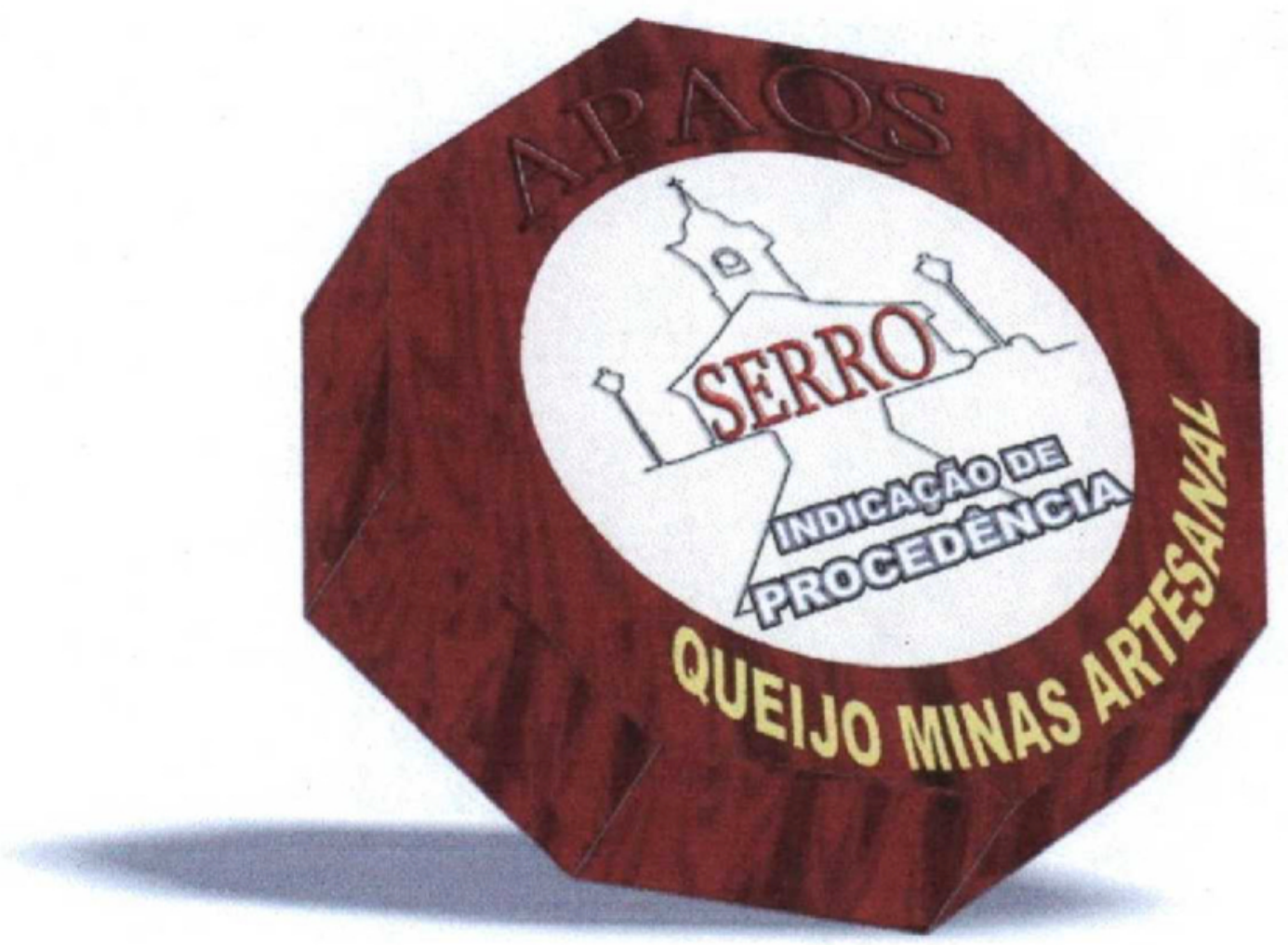

Figura 14. Reprodução da Etiqueta de Indicação de Procedência Serro para o Queijo Minas Artesanal. Fonte: INPI.

Pode-se notar, neste ponto que, no dossiê do INPI do Serro, as regras sanitárias não apenas não são discutidas, como são tratadas como naturalizadas e como se convivessem sem problemas com as tradições locais. Reflexo disso é a recorrência no regulamento em questão da expressão "de acordo com o saber tradicional” na descrição do processo de fabricação do Queijo Minas Artesanal do Serro - ao mesmo tempo que se apresenta a exigência de utilização de tanques, formas e bancadas de plástico, inox, polietileno ou outro material "de fácil higienização". Por fim, a definição de mecanismos de controle da qualidade dos queijos com direito a IP pela associação também faz parte dos itens mandatórios do regulamento de uso.

No estatuto da APAQS, um item chama a atenção: o inciso $\mathrm{X}$ do artigo $5^{\circ}$ inclui, entre as possibilidades de ação da associação: "Apoiar o desenvolvimento do turismo rural de seus associados, gerando aumento da renda, e valorização dos produtos e das terras". Há apenas uma outra menção ao turismo em todo o documento, mesmo que, como vimos no capítulo anterior, 
as Indicações Geográficas tenham seu surgimento associado ao desenvolvimento do turismo gastronômico na Europa. Trata-se de um trecho do dossiê de registro do Modo de Fazer Queijo Artesanal do Serro como patrimônio imaterial do estado, anexado como comprovação da notoriedade do produto. Nesse ponto, o aumento do turismo na região é apontado como consequência do investimento em iniciativas de preservação do patrimônio cultural do Serro, isto é, como uma ferramenta de desenvolvimento da região.

Ainda se destacam no dossiê duas referências à França. A primeira é na Ata da Reunião Ordinária do Conselho Regulador para Indicação de Procedência Serro para o Queijo Minas Artesanal da APAQS, de 29 de maio de 2009, que menciona a possibilidade de um intercâmbio para a capacitação e visita de campo de dois produtores da APAQS e da APROCAN (associação que representa a IP do Queijo Minas Artesanal da Canastra) para o país europeu, a fim de conhecer regiões e produtores portadores de selo de Indicação Geográfica. A segunda referência vem nas palavras de um produtor, que, de acordo com o texto, vê na certificação uma forma de agregar valor ao seu produto. Assim, ter um queijo dentro das normas federais, o faria ter um produto mais nobre: "É unir a tradição de Minas Gerais à tradição secular da qualidade francesa" (EMATER, AGRIFERT, 2009, p. 9).

Os documentos "Demonstração da Notoriedade Histórica e Cultural do Serro para o Queijo Minas Artesanal”, produzido pela EMATER-MG e pela AGRIFERT em julho de 2009, e "Caracterização da Micro Região do Serro como Produtora de Queijo Minas Artesanal”, da EMATER-MG, de 2002, são o trecho do dossiê do INPI que mais se aproxima dos outros aqui analisados. Eles trazem um breve histórico da cultura do queijo na região. Alguns trechos se sobressaem. Como este:

Nos tempos atuais, esta tradição continua sendo mantida, pelos conhecimentos passados de geração para geração. Pouca coisa foi mudada, as formas hoje são de plástico e o coalho é industrial, comprado já pronto, o que proporciona mais higiene e segurança do produto, mas a técnica de produção continua inalterada, excetuando-se, o cuidado com a higiene do produto que é muito maior, atualmente (EMATER, AGRIFERT, 2009, p. 6, grifos nossos).

Percebe-se um discurso de minimização das mudanças sofridas no processo de produção do queijo por conta da legislação sanitária, ao exaltar a segurança e o maior grau de higiene como consequência dessas transformações ${ }^{53}$. Ao mesmo tempo, o texto apresenta uma preocupação com o que denomina de "sofisticação" da indústria de laticínios, que, por um lado, traz benefícios à qualidade e padronização dos produtos, e, por outro, "peca por negligenciar

\footnotetext{
${ }^{53}$ Relação questionada por alguns pesquisadores. Ver nota 58.
} 
um dos aspectos mais importantes da cultura de um povo: sua tradição" (EMATER, AGRIFERT, 2009, p. 7).

Hoje, de uma maneira silenciosa, indústrias de queijos das mais tradicionais do país vêm passando ao controle de grupos dominantes no mercado e, na maioria das vezes, inteiramente alheios aos aspectos históricos, tradicionais que representam marcas, sobre as quais passam a ter direito de produção e comercialização. Quando estas marcas simplesmente não desaparecerem, transformam-se em excelentes atrativos para a venda de produtos, cuja qualidade, por forçar mudanças nos métodos tradicionais elaboração e pela busca de maiores lucros, vem desmerecer a reputação que os anos e o gosto popular anteriormente lhes atribuíram, com justa razão (EMATER, AGRIFERT, 2009, p. 7).

Percebe-se, assim, uma preocupação com a distorção das qualidades do Queijo do Serro, ligadas à cultura local, mas por uma perspectiva mais mercadológica: não se trata de evitar o desaparecimento do conhecimento tradicional, mas, sim, de evitar que o nome passe a corresponder a um produto distinto do que o fez notório. Aproxima-se mais de um discurso de proteção de marca. É ainda relevante o fato que o documento em questão foi redigido em 2009, após o reconhecimento do Modo de Fazer do Queijo Minas Artesanal pelo IPHAN como patrimônio imaterial brasileiro (2008). O registro do IPHAN e do Instituto Estadual do Patrimônio Histórico e Artístico de Minas Gerais (IEHPA), de 2002, são citados como fatores que reforçam a notoriedade do queijo do Serro. O dossiê deste último, inclusive, é um dos documentos anexados ao processo do INPI para se comprovar notoriedade, enquanto o parecer e a certidão de registro do IPHAN e não o dossiê, compõem também a lista de anexos. Uma ausência, retomando May (2011), que pode construir uma realidade social e versões de eventos.

Os textos que compõe o dossiê do INPI também ressaltam informações técnicas: geológicas, geográficas, biológicas, químicas, etc., ao passo que informações históricas e abordagens sociológicas são superficialmente apresentadas. Além disso, a linguagem varia de acordo com o documento. Não se tratam, em sua maioria, de textos acadêmicos, mas análises técnicas, legislações, reportagens e outras documentações que comprovem a notoriedade do bem em questão. É interessante ressaltar que o termo terroir não aparece no dossiê. No entanto, ao longo dos textos, é possível notar o reforço da ideia de que as condições físico-ambientais e culturais são determinantes para a qualidade do queijo do Serro.

O processo encerrou com o registro da IP em 13 de dezembro de 2011. Ou seja, entre ser depositado (data de entrada no INPI e não do pedido) em 16 de abril de 2010 e encerrar-se, o processo levou pouco mais de um ano e meio. Entretanto, as reuniões da APAQS e definição de uso do selo de IP já eram discutidas desde maio de 2009 - e os documentos da EMATER 
datam de 2002. Percebe-se, assim, que há um trabalho prévio de construção do dossiê, orientado por parceiros do INPI, para que a documentação chegue completa à instituição.

\section{Canastra}

O dossiê da Indicação de Procedência do queijo da Canastra é o mais extenso, com 441 páginas, divididas em dois volumes. Isso se deve à adição de alguns documentos referentes à região do Serro. O que, junto à data de depósito de 06 de março de 2010 (registrada no INPI em 16 de abril do mesmo ano, mesmo dia da do Serro), indica que os esforços para a construção das coleções de documentos podem ter sido feitos em conjunto. Dessa forma, o estudo de Demonstração da Notoriedade Histórica e Cultural da Canastra para o Queijo Minas Artesanal também foi elaborado pela EMATER-MG e pela AGRIFERT em julho de 2009.

Entretanto, neste texto, o processo histórico e os aspectos culturais do bem são um pouco mais aprofundados, com depoimentos de antigos moradores da região tratando da memória do modo de fazer ainda no tempo em que se utilizava o coalho de bucho de tatu. Mais uma vez, os aspectos ambientais, naturais unidos à intervenção humana são apontados como os fatores determinantes da qualidade única do queijo da Canastra. Não se fala diretamente em terroir, mas o discurso está presente em toda a justificativa. Os aspectos econômicos da produção leiteira da região e o impacto da produção de queijo também são bastante destacados. Assim como no dossiê do Serro, é possível notar o detalhamento de informações técnicas geográficas, biológicas e químicas. O discurso de melhora da qualidade do queijo através da adequação à legislação sanitária do país, também se repete - inclusive com trechos idênticos ao do dossiê anterior.

O turismo ecológico, estimulado pela beleza das serras e a abundância de cachoeira é abordado em "Caracterização da Microrregião da Canastra como Produtora de Queijo Minas Artesanal" (São Roque De Minas / novembro 2004) e reafirmado ao longo do dossiê como uma atividade expressiva de renda para as famílias locais. No estatuto da Associação dos Produtores de Queijo Canastra (APROCAN), artigo $2^{\circ}$, alínea g, inclui-se entre as finalidades da associação: "Estimular e promover o potencial turístico da região, bem como o aprimoramento sócio - cultural dos associados, seus familiares e das comunidades". 


\section{Indicação de Procedência CANASTRA Queijo Minas artesanal

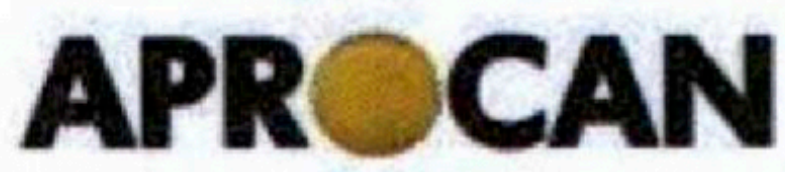

Figura 15. Reprodução do modelo de etiqueta apresentado no Regulamento de Uso da IG da Canastra. Fonte: INPI.

O parecer do IPHAN para o registro do Modo Artesanal de Fazer Queijo de Minas, assim como no caso do Serro, integra a coletânea documental. Neste dossiê, entretanto, ele é seguido pela publicação "Programa Selo Azul da Agroqualidade - Projeto pró-queijo Canastra", do IMA, que

contempla, entre outros aspectos, a mobilização dos produtores em ações associativistas, ações de capacitação de técnicos e dos produtores, padronização de produtos, normatização de processos e embalagens e finalmente a outorga dos certificados de origem e de autenticidade higiênico-sanitário (MINAS GERAIS, 1998, p.1, grifos nossos).

Dessa forma, discursos muitas vezes contraditórios, se unem no dossiê. Ainda chama a atenção sobre o formato de coleção de documentos, a repetição de documentação ao longo do compêndio, sem explicações para tanto - se foi por erro (o que nos parece mais provável) ou intencionalmente.

Assim como no regulamento de uso da IP do Serro, no da Canastra há regras para todo o processo de produção do queijo, desde a matéria-prima, tipo de gado, criação, alimentação, etc. A diferença é que a Indicação de Procedência da Canastra para o Queijo Minas Artesanal pode ser fabricado em três tamanhos: o Canastra, o Canastra Merendeiro e o Canastra Real. Tratam-se dos três tamanhos tradicionais de se fazer queijo na região - Canastra, de 900 a $1.300 \mathrm{~g}$; Merendeiro, 300 a 400g; e Canastra Real, 5 a $7 \mathrm{~kg}$. Outro ponto interessante do regulamento em questão é a possibilidade de a casca do queijo apresentar manchas e leveduras quando maturada. Alguns especialistas ligados ao IPHAN e Slow Food criticam, alegando que o costume antigo era lavar o queijo e mantê-lo sempre amarelo. E que o hábito de manter mofos veio como uma influência das técnicas francesas, nos últimos anos. Entretanto, há produtores 
que recordam relato do avô sobre um mofo cor de ferrugem que deu uma vez, nunca mais tinha ocorrido e agora ele viu seus queijos adquirirem tal coloração.

Apesar de no regulamento de uso da IP apresentar-se uma marca da APROCAN como etiqueta, no documento oficial não há indicação de uma etiqueta para a identificação da Indicação Geográfica da Canastra. O dossiê contempla ainda um documento de Caracterização do Queijo Minas Artesanal da Serra da Canastra desenvolvido em 2006/2007, pela Arifert, APROCAN e a Secretaria da Agricultura Familiar do Ministério do Desenvolvimento Agrário (MDA), já com o objetivo de preparar documentação para o pedido de IG junto ao INPI. Tratase de um trabalho de identificação técnica de todo o processo e fatores que envolvem a produção queijeira na região. Com muitas fotos desde os pastos, queijarias, ordenha e feitura do queijo e até mesmo avaliações gustativas dos produtos.

Quanto à duração, processo da IP da Canastra foi um pouco mais longo que o do Serro, pois a APROCAN teve que detalhar melhor em seu estatuto como faria o controle de qualidade dos produtores. Assim, a Indicação geográfica foi concedida em 13 de março de 2012.

\section{Cajuína do Piauí}

A Cajuína é o processo mais longo dos aqui avaliados: levou 2 anos e quatro meses entre o pedido de IP e a concessão da certificação. É também o mais recente, foi concedido em 26 de agosto de 2014. Outro ponto que difere este dossiê dos demais é que a instituição que requereu a IG não é uma cooperativa, mas uma União das Associações Cooperativas e Produtores de Cajuínas do Estado do Piauí, a PROCAJUÍNA. Dessa forma, quase metade do volume do dossiê é de documentos comprovatórios da instituição das respectivas cooperativas ou da fundação das empresas associadas.

No Regulamento de Uso da Indicação de Procedência Piauí chama a atenção a restrição às variedades de caju autorizadas como matéria prima. Diz o artigo $2^{\circ}$ :

São autorizadas para a Indicação de Procedência "Piauí", predominantemente, as variedades de Caju relacionadas a seguir:

Variedades de Caju: caju nativo e caju do clone de cajueiro-anão-precoce CCP 076.

Haverá três variedades de Cajuína: "Cajuína de Caju Nativo" fabricada somente com cajus nativos, "Cajuína Mista" fabricada com cajus nativos e CCP 076 em quaisquer proporções e "Cajuína de Caju CCP 076" fabricada somente com a variedade de caju CCP 076.

A variedade "Cajuína Mista" poderá contar com até $20 \%$ de suco de outras variedades de clones de caju. Esta concessão visa estimular a redução do risco de pragas que a cultura de uma única variedade poderia ensejar. Dada a dinamicidade das pesquisas e avanços da ciência, outras variedades de caju poderão vir a ser consideradas desde que aportem ganhos de qualidade ao produto (PROCAJUÍNA, 2010, grifos nossos). 
É interessante notar, ao longo dos documentos, um discurso bastante favorável ao uso dos cajus clones. Na realidade, há uma ausência de reflexão sobre seus possíveis danos ambientais. No máximo, como no grifo acima, quando se diz que para a cajuína mista poderia se utilizar outras variedades de clones, uma vez que o cultivo de uma única variedade é mais suscetível a pragas. Entretanto, ao mesmo tempo, é possível fazer a cajuína apenas do caju clone, o que estimularia a monocultura.

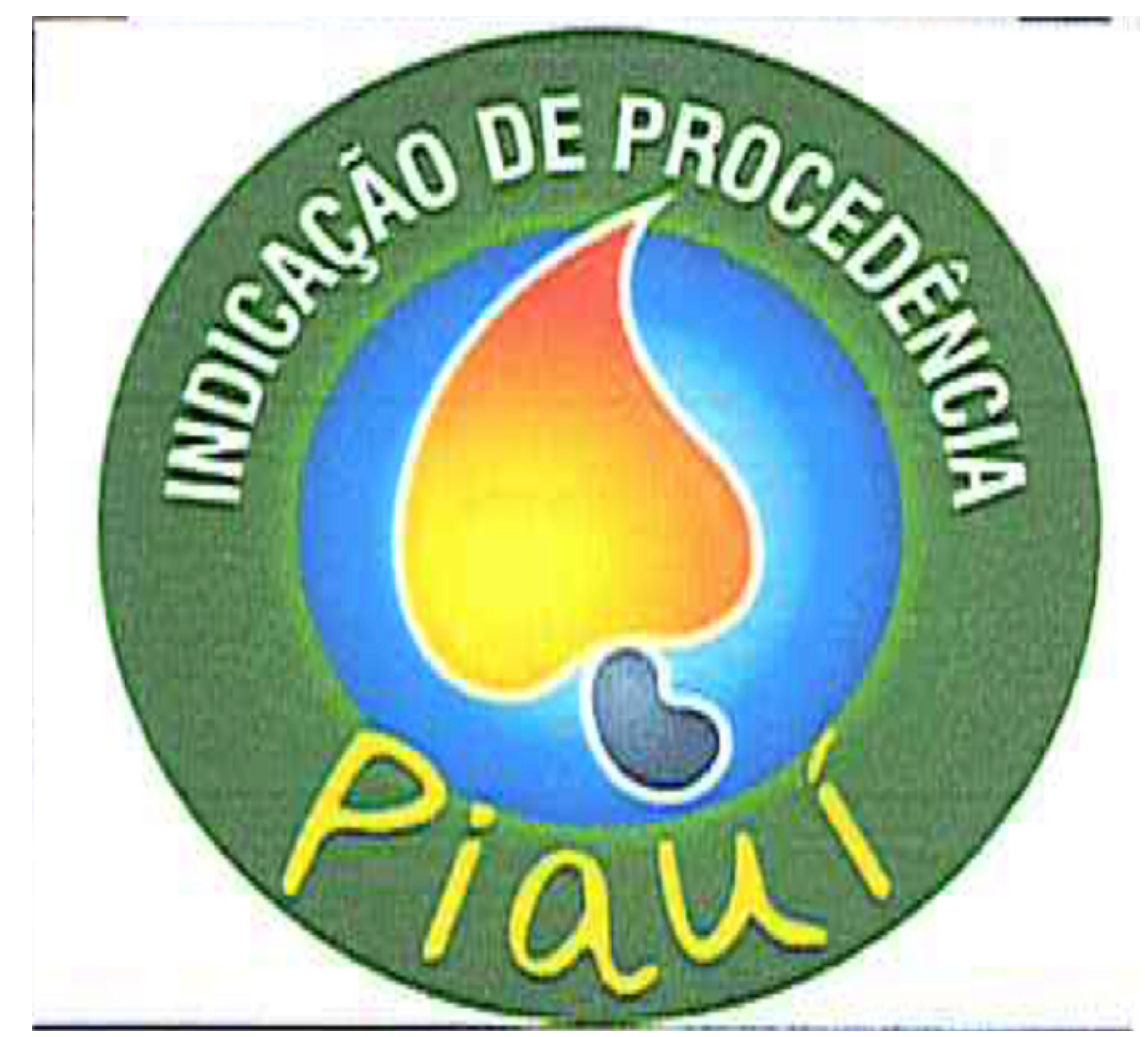

Figura 16. Reprodução da Etiqueta de Indicação de Procedência da Cajuína do Piauí. Fonte: INPI.

Outro ponto a ser destacado é o sistema de produção previsto no regulamento de uso: baseada nas normas estabelecidas pela Embrapa - e pela legislação sanitária, é obrigatória a lavagem e sanificação dos cajus. Esse ponto não é fonte de nenhum questionamento nos textos do dossiê do INPI, mas vai contra à tradição do modo de fazer da bebida que higieniza os frutos na própria água (suco), e, mais que isso, proíbe o contato do fruto com água. Há ainda uma etapa extra apresentada neste dossiê, que não é citada em nenhum dos outros inventários: o préaquecimento. Após a filtração, o suco deve ser pré-aquecido entre 85 e $90^{\circ} \mathrm{C}$ por 15 minutos, mas sem evaporar. Isso evitaria o choque térmico e a quebra das garrafas. No entanto, reafirmamos, esta etapa não é mencionada por nenhum ator nos demais dossiês.

Ainda sobre o processo de produção, dois pontos valem destaque. Um é a menção no subsídio técnico da Embrapa de que o liquidificador não deve ser jamais utilizado. Esse equipamento inclusive não condiz com as práticas tradicionais. Entretanto, ele é utilizado no 
vídeo que integra o dossiê do IPHAN, acima analisado, apresentado pelo presidente de uma Cooperativa de produtores, que integra a lista de associados da Procajuína. Ainda chama a atenção a ausência de menção do uso tradicional da resina do cajueiro no processo de clarificação do suco. Trata-se apenas da eficácia da gelatina, alertando quanto à proibição do uso da cola (prática recorrente até recentemente). O processo de filtragem é apresentado conforme o tradicional. A grande diferença aqui é que os equipamentos considerados adequados correspondem à legislação sanitária, ou seja, são de inox.

O dossiê da cajuína ainda apresenta um relatório técnico com a caracterização sensorial da cajuína produzida no estado do Piauí, desenvolvido pela UFPI. O trabalho, que compõe como documento comprobatório de notoriedade, reforça o discurso de que a forma artesanal da produção da cajuína dificulta uma maior produtividade e, consequentemente, um retorno financeiro maior. Nessa perspectiva, a falta de uniformidade na cor do produto final fruto do processo artesanal é apontado como um entrave à padronização e, consequentemente, à qualidade do produto final. O uso do termo 'padronização', aliás, é bastante recorrente nos documentos do INPI. Sempre apontado como um fator fundamental para alcançar um produto de qualidade.

Assim como nos dois dossiês anteriormente analisados, há pouco aprofundamento sobre o contexto histórico-sociológico da cajuína. Nesse ponto, este dossiê entra em conflito com o do IPHAN. Apontado como subsídio técnico, a publicação "Cajuína: informações técnicas para a indicação geográfica de procedência do Estado do Piauí", de José Ribeiro Lopes, publicado pela Embrapa Meio-Norte, afirma que

Quando os portugueses chegaram ao Brasil, já encontraram a cajuína, uma bebida desenvolvida artesanalmente pelos indígenas, que habitavam a região Nordeste, usada para comemorar as vitórias nas grandes batalhas que travavam pelo domínio dos cajueirais. No entanto, foi no Estado do Piaú que a cajuína entrou num estágio de desenvolvimento, tornando-se a bebida tradicional dos piauienses (RIBEIRO, 2010, p. 16)

Mais à frente, o autor retoma as origens da bebida, afirmando que

Deixando-se o suco [de caju] em condições ambientais por dois ou três dias, ele fermenta, transformando-se em 'mocororó', bebida legada pelos índios que ainda hoje encontra apreciadores. Cozinhando-se o 'mocororó' obtém-se o 'cauim' que depois de frio era consumido pelos nossos selvagens para celebrar as vitórias nas grandes batalhas que travavam pelo domínio dos cajueiros (RIBEIRO, 2010, p. 83).

Percebe-se uma completa ausência de menção do álcool contido no mocororó, ou de que a cajuína nasce como uma bebida de elite. Ao contrário da complexidade e dificuldade de se 
definir claramente as origens da bebida apresentadas no dossiê do IPHAN, neste ela é simplificada, de forma que gera informações inconsistentes.

O dossiê ainda traz, através de diversas análises técnicas, com gráficos e números de produtividade por hectare, informações sobre os tipos de caju mais apropriado para a produção da cajuína. Percebe-se que a perspectiva foca muito em desenvolvimento econômico, sem abordar fatores socioculturais e ambientais. Um exemplo é uma das justificativas para que a cajuína se torne IG - que retoma a reflexão apresentada no capítulo anterior sobre os usos indiscriminados do conceito de "sustentável" e as contradições assim criadas. De acordo com o texto, a razão para Indicação Geográfica da cajuína reside no fato que, com ela,

[...] a cajuína passará a ser conhecida nacionalmente, devido à padronização do seu processo de fabricação, qualidade e competitividade com outras bebidas não fermentadas e sem aditivos, conquistando novos mercados, ampliando a sua produção e dando sustentabilidade ao agronegócio da cajucultura piauiense (RIBEIRO, 2010, p. 16).

É possível perceber através dessas três análises de dossiês do INPI que, por não se tratar de um documento único, que reúne todas as informações, as processa e repassa, se percebe aqui algumas quebras de continuidade e tantas outras contradições internas. A análise do processo também traz à luz a sua rigidez. Como já havia sido possível notar ao examinar as fichas de candidatura, trata-se de um inventário mais jurídico, que apresenta um discurso mais focado em fatores de desenvolvimento econômico do que sociocultural.

É importante ainda ressaltar que estes dossiês, ao contrário dos demais aqui analisados, não estão acessíveis ao público. Assim, eles são construídos pelas associações que pleiteiam a certificação com o intuito de satisfazerem os pré-requisitos impostos pelo INPI. A publicação anteriormente mencionada, lançada em parceria com o SEBRAE, que seria nossa primeira base de análise, se difere completamente dos documentos aqui examinados (vide as reproduções a seguir). Trata-se de textos curtos, em português, espanhol e inglês: uma breve introdução, um pouco da história e tradição, do território, do produto, dos benefícios da IG, dados técnicos, e dados da entidade representativa. Além de fotos profissionais ilustrando. Dessa forma, essa publicação poderia exercer um papel de divulgador turístico das IGs brasileiras. Função que os dossiês aqui analisados não priorizam diretamente. 

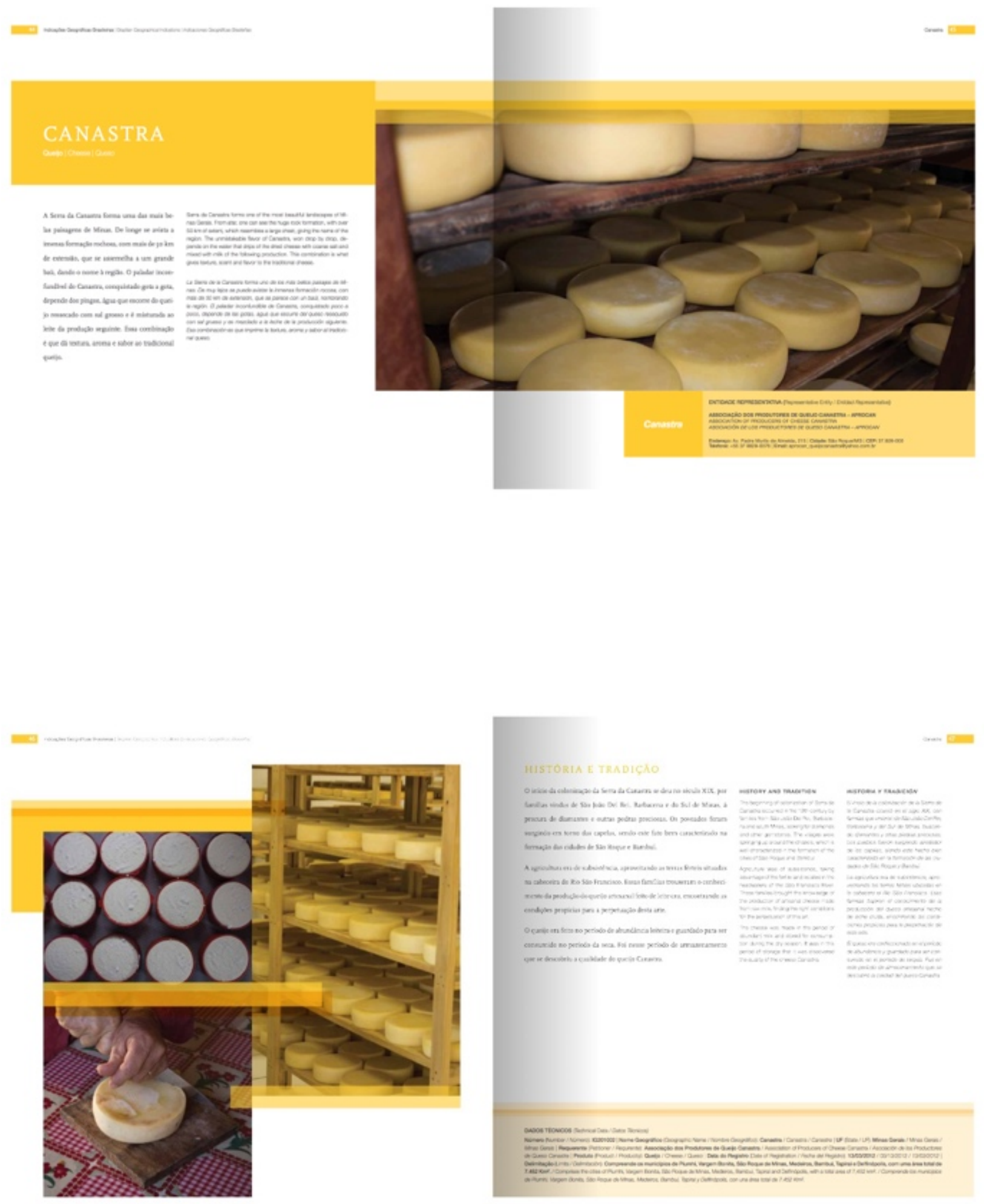


\subsubsection{Slow Food}

Em um primeiro momento, havíamos selecionado para a atual análise três produtos da Arca do Gosto, inventário do Slow Food: os queijos da Canastra, do Serro e da Serra do Salitre ou Alto Paranaíba. No entanto, com a inclusão da cajuína na catalogação, optou-se por também abarcá-la nesta análise. Outra mudança em relação ao projeto inicial de pesquisa foi a escolha de não inserir neste estudo nenhum produto do projeto Fortalezas, também do Slow Food. Isso se deu por se concluir que ele seria uma continuidade da Arca do Gosto, um aprofundamento. Além disso, os bens avaliados nos inventários das outras duas instituições integram apenas a Arca. Assim, preferimos atermo-nos a esses dossiês, mantendo um padrão de comparação mais justo entre os três processos.

Ao analisar os dossiês percebe-se que se tratam de textos curtos, concisos, que trazem informações básicas sobre o produto em questão. No entanto, deve ser levado em conta que, se por um lado se observa uma intencionalidade de ser acessível - o discurso recorrente entre atores responsáveis pela Arca é que ela seja fonte de pesquisa para estudantes, cozinheiros e curiosos do mundo todo - por outro, os produtos do Brasil na catalogação internacional se tornam pouco acessíveis aos brasileiros. Em 01 de outubro de 2016, constavam no site da Arca do Gosto Internacional, 118 produtos nacionais. Na mesma data, o site do Slow Food Brasil só apontava 57 desses itens. O problema é que a plataforma internacional só está disponível em duas línguas: inglês ou italiano.

Há uma exceção: no dossiê da Cajuína, depois do texto em uma das duas línguas estrangeiras, está disponível a descrição em português. No entanto, para chegar até ali, é preciso passar por três páginas em inglês ou italiano. Dos quatro bens aqui analisados, apenas o Queijo da Canastra tem sua descrição no site do Slow Food Brasil. Por isso, optou-se por analisar os quatro dossiês em inglês e, no caso da Cajuína e do Queijo da Canastra, fazer um comparativo também com o texto em português.

\section{Queijo Canastra Artesanal}

Os dois dossiês, em inglês e português são bastante semelhantes, mas não idênticos. Enquanto no primeiro há toda a descrição de como é feito o queijo, no segundo esse trecho está ausente. No entanto, este último traz algumas informações extras em relação ao texto internacional: número de queijos produzidos, famílias beneficiadas e associações cooperativas envolvidas; as dificuldades enfrentadas pelos produtores artesanais que são tratados iguais aos grandes em relação às exigências sanitárias e fiscais; e o fato do queijo ter, além do registro do 
IPHAN, citado no texto em inglês, também ser certificado pelo INPI com o selo de Indicação Protegida (IP).

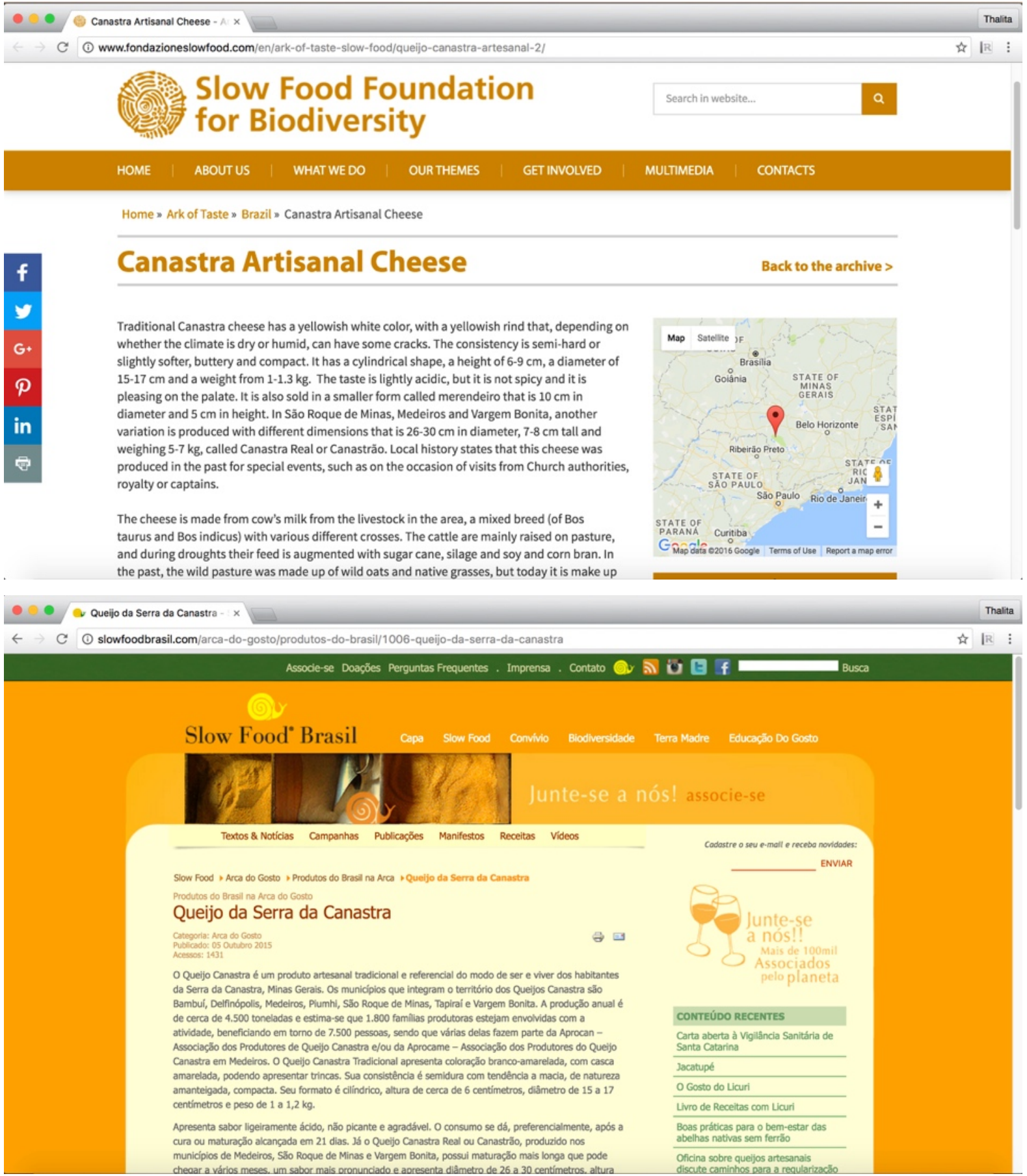

Figura 18. Reprodução dos dossiês do Queijo da Canastra nos sites do Slow Food Internacional (acima) e do Slow Food Brasil.

No caso do presente dossiê (e que se repetirá nos outros dois de queijos), apesar de virem de fichas bastante abertas, é possível observar uma estruturação do texto semelhante, contendo: características organolépticas, matéria-prima, modo de fazer e produção, venda, histórico e problemas. Trata-se, no entanto, de dossiês extremamente curtos. Capazes de dar apenas um breve panorama do que constitui o bem e porque ele está em risco de extinção. 


\section{Queijos do Serro e da Serra do Salitre ou Alto Paranaíba}

Aqui unimos as análises desses dois dossiês por serem muito similares - assim também como a versão em inglês do Queijo Artesanal da Canastra. Trata-se de textos curtos, bem estruturados, que descrevem as características organolépticas dos produtos, sua matéria-prima (leite cru de vaca), o modo de fazer com suas pequenas especificidades, a delimitação de território de cada um deles, seu histórico, de origens coloniais, e a dificuldade enfrentada pelas imposições de regras sanitárias que levam muitos produtores para a informalidade, comprometendo a segurança alimentar e a rastreabilidade.

\section{Cajuína}

O dossiê da Cajuína traz um novo formato ao disponibilizar uma versão em português ainda no site do Slow Food Internacional. O mais recente dos quatro aqui analisados, ele também chama a atenção por apresentar informações dissonantes do dossiê do IPHAN, anteriormente discutido. Por isso, entraremos aqui em alguns detalhes de conteúdo, para que possamos, ao fim deste capítulo, traçar um quadro comparativo dos inventários em questão mais fidedignamente.

Primeiramente, é necessário ressaltar as diferenças entre os dois textos apresentados no mesmo dossiê: a versão em inglês e a em português possuem algumas dissonâncias relevantes. Já de início, o texto em português detalha a ligação da cultura do caju com o estado do Piauí e descreve a variedade do caju “anão-precoce", que define como a mais adequada para a produção da cajuína. Nenhuma dessas informações aparecem no texto em língua estrangeira. Há ainda, uma diferença nos dois textos sobre o período de produção da cajuína: enquanto na primeira versão se diz de junho a setembro, na segunda se fala de agosto a outubro.

Outro ponto interessante de diferença entre as duas versões é a narrativa do processo de feitura da bebida - além de ser mais detalhada na redação brasileira, em inglês não se menciona o uso de cola de sapateiro na etapa de clarificação, ou a proibição de se lavar o fruto com água e nem o valor social do preparo tanto para as mulheres produtoras como na hospitalidade local. Ao contrário, simplifica seu uso: "The final result is a natural beverage, without any added preservatives or sweeteners, consumed fresh as a thirst-quencher or to accompany fish, seafood or meat dishes" $" 54$.

\footnotetext{
${ }^{54}$ Disponível em http://www.fondazioneslowfood.com/en/ark-of-taste-slow-food/cajuina/. Consultado em 03 out. 2016. Tradução nossa: "O resultado final é uma bebida natural, sem adição de adoçantes ou preservativos, consumida fria para saciar a sede ou para acompanhar pratos de peixe, frutos do mar ou carne".
} 


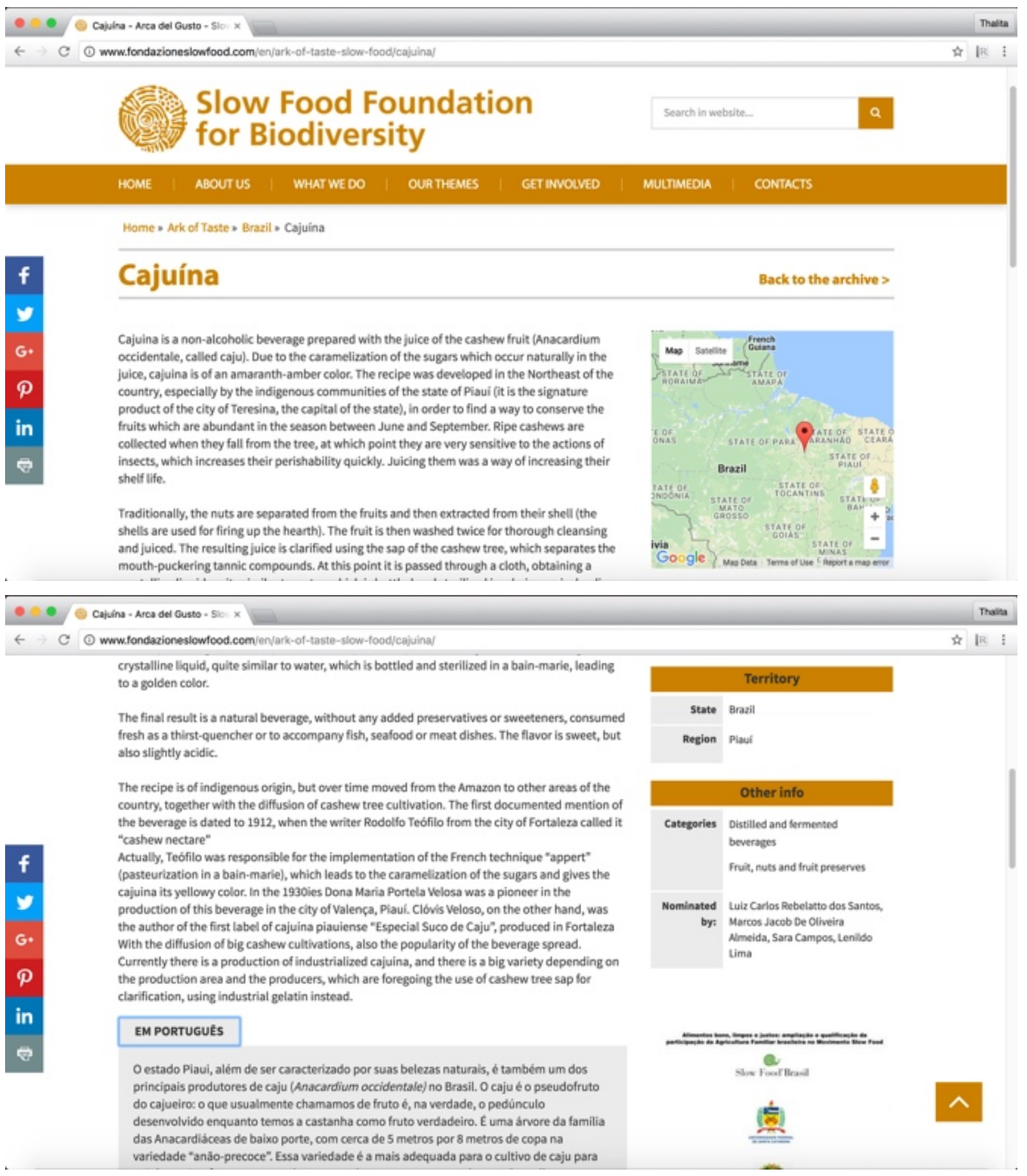

Figura 19. Reprodução do dossiê da Cajuína com suas versões em inglês e português no site do Slow Food Internacional.

Por fim, os dois textos diferem em relação aos problemas enfrentados pela cajuína. Enquanto em inglês se diz que a bebida tradicional está ameaçada por ter se disseminado e ter se industrializado, com o uso de gelatina no processo de clarificação, em português o risco está no crescimento da popularidade dos refrigerantes e a preferência dos jovens por essas bebidas gasosas ao invés da tradicional. Além do que, nesta última, o registro no Livro dos Saberes do IPHAN e o selo de Indicação de Procedência do INPI são apontados com fator que fortalece as práticas associadas a esse bem da identidade piauiense. 
Há um ponto, no entanto, comum aos dois textos, mas contrária à do dossiê do IPHAN (que é citado na versão brasileira). Trata-se da afirmação de que a cajuína tem origens indígenas e amazônicas:

The recipe is of indigenous origin, but over time moved from the Amazon to other areas of the country, together with the diffusion of cashew tree cultivation.

$[\ldots]$

Ademais, por ser originário da Amazônia, a cajuína também está alicerçado na história indígena, visto que os indígenas tinham o rito da cauinagem, que era a transformação do caju em uma bebida denominada cauim. Através dos processos de migração e miscigenação, o cauim foi inserido na cultura piauiense, denominado cajuína. ${ }^{55}$

Como por seu perfil sucinto o dossiê da Arca do Gosto não apresenta o embasamento dessas informações, optou-se aqui por contrastá-la com o dossiê do IPHAN. Primeiramente porque este descreve as guerras do caju, que seriam travadas pelos indígenas, exatamente pela ausência do fruto no interior do país, o que contradiz a afirmação acima.

As vastas e frondosas matas de caju se concentravam no litoral, sendo as maiores delas, segundo Fernandes, entre Itamaracá e o Rio Grande do Norte, sob o domínio geral dos Potyguaras. Mas estes tinham que defendê-las constantemente, durante a safra da fruta, tanto de povos aparentados, quanto dos Caetés e Tabajaras, como dos Tapuias do sertão que desciam o litoral para travar as guerras do caju. Entre essa riqueza de informações apontadas por Fernandes, atentamos para um pequeno detalhe importante para a nossa pesquisa: o testemunho de que essas guerras eram impulsionadas pelo fato dos cajus não se encontrarem muito ao interior (apud FERNANDES, Herekman 1982 [1639], p. 67). Se deduzirmos, a partir dessa indicação, que o processo de colonização do cajueiro do litoral em direção ao interior se deu gradativamente, em um regime fundiário, no qual até presentemente era proibido ao posseiro o plantio de árvores, para evitar reivindicações de posse da terra a partir de benfeitorias, podemos entender com mais clareza o porquê dos frutos só estarem disponíveis aos proprietários de terras que os plantassem e, portanto, sua exclusão da produção da cajuína até que os cajueiros se espalhassem de forma massificada pelo Estado, fomentados por políticas públicas de incentivo à produção agrícola. (BRASIL, 2009, p. 89, grifo nosso)

Além disso, o dossiê do IPHAN apresenta a cajuína exatamente como uma versão "civilizada" da bebida de origem indígena: pura, cristalina e não alcóolica. Portanto, defini-la como de origem indígena pode ser considerado impreciso.

Ao encerrar essa análise dos dossiês da Arca do Gosto do Slow Food, percebe-se que o discurso de acessibilidade universal permanece, mas com falhas. Ele fica claro ao se propor uma ficha simples que culmina com dossiês concisos, com informações curtas, que dão um

${ }^{55}$ Disponíveis em http://www.fondazioneslowfood.com/en/ark-of-taste-slow-food/cajuina/. Consultado em 03 out. 2016. Tradução nossa: "A receita é de origem indígena, mas ao longo do tempo mudou da Amazônia para outras áreas do país". 
contexto geral sobre o produto. No entanto, tal acessibilidade fica comprometida quando as informações não são traduzidas para o português. Mais ainda quando se tem versões dissonantes nas duas línguas. As diferenças de conteúdo podem, talvez, refletir públicos diversos.

Quando se passa de 'para quem se escreve' para 'quem escreve' retorna-se ao discurso de diversidade de fontes: as fichas de candidatura devem ser de simples compreensão, para que de cozinheiros a acadêmicos, passando por produtores e ativistas, todos possam inscrever os produtos de sua tradição alimentar na Arca do Gosto. O importante é que se tenha uma narrativa, que se explique o porquê daquele item ser parte da cultura local e estar em risco. Cria-se um processo ágil - a grande mudança de paradigmas do projeto foi exatamente para que se angarie um número maior para a catalogação, acelerando a avaliação de candidaturas. Entretanto, não se trata de um processo aprofundado ou necessariamente bem embasado, o que pode gerar, como observado aqui, algumas incongruências.

Nessa perspectiva, para que o projeto do Slow Food passe a ser uma importante ferramenta de desenvolvimento do turismo gastronômico no Brasil assim como foi na Itália, é necessário que as informações tenham maior consistência e que sejam acessíveis aos brasileiros, isto é, estejam disponíveis em português. Ou corre-se o risco de se construir projetos voltados apenas a estrangeiros, corrompendo o ideal de empoderamento da população local, que faz parte, inclusive, da filosofia do movimento.

\subsubsection{As Ações Complementares}

A análise aqui desenvolvida visa compreender o processo de construção dos inventários do IPHAN, INPI e Slow Food. Assim, examinamos as fichas de candidatura e os dossiês gerados para o registro do bem ou concessão do selo. Entretanto, há outras práticas e procedimentos desenvolvidos após essa etapa que também refletem o sentido de cada uma dessas catalogações. São essas possibilidades que discutiremos antes de concluir nossa análise dos inventários.

\section{IPHAN}

No caso do IPHAN, todo o processo até aqui analisado não se encerra no registro, ao contrário: ele é o início das ações de salvaguarda. Trata-se do objetivo final de se inventariar um bem: garantir a sua continuidade. Para tanto, nos dossiês são apontadas sugestões de ações de salvaguarda. Uma vez que o bem foi inscrito em um dos quatro Livros (dos Saberes, de Celebrações, das Formas de Expressão e dos Lugares), inicia-se os procedimentos de planejamento dessas ações. 
Em geral não é possível definir um período de tempo para a completa implementação da salvaguarda. A previsão é de que seja iniciada no decorrer da primeira década após o Registro, com vistas ao fortalecimento da autonomia dos detentores/produtores do bem cultural na produção, reprodução e gestão de seu patrimônio e a sustentabilidade do bem cultural no médio e longo prazo. (BRASIL, 2015c, pp. 4-5)

O essencial, destacado no Termo de Referência para a Salvaguarda de Bens Registrados, de julho de 2015, é o envolvimento direto dos atores sociais produtores e reprodutores do bem, os seus detentores, nesse processo.

A salvaguarda do bem Registrado, portanto, deve ser compreendida como um processo no qual os detentores estarão mobilizados com o Iphan e parceiros para identificar com maior profundidade a situação na qual o bem cultural se encontra; ou seja, reconhecer eventuais problemas que enfrentam para a continuidade da prática; aspectos da produção que precisam ser mais valorizados; refletir sobre os meios possíveis para resolver tais questões; planejar estratégias de execução; identificar e comprometer instituições públicas das três esferas da gestão pública que desenvolvam políticas afins ao objeto da salvaguarda, conforme o pacto federativo; participar e acompanhar a execução das ações planejadas. (BRASIL, 2015c, p. 22)

Para tanto, a Coordenação-Geral de Salvaguarda definiu no Termo de Referência para a Salvaguarda de Bens Registrados (BRASIL, 2015c) quatro eixos que abrangem 15 tipos de ações possíveis:

\begin{tabular}{|c|c|c|}
\hline & Eixos & Ações \\
\hline \multirow{3}{*}{ Eixo 1} & \multirow{3}{*}{$\begin{array}{l}\text { Mobilização Social e } \\
\text { Alcance da Política }\end{array}$} & $\begin{array}{l}\text { 1.1. Mobilização e Articulação de comunidades e grupos } \\
\text { detentores }\end{array}$ \\
\hline & & 1.2. Articulação Institucional e Política Integrada \\
\hline & & 1.3. Pesquisas, Mapeamentos e Inventários Participativos \\
\hline \multirow{2}{*}{ Eixo 2} & $\begin{array}{l}\text { Gestão Participativa no } \\
\text { processo de salvaguarda }\end{array}$ & $\begin{array}{l}\text { 2.1. Apoio à criação e manutenção de coletivo } \\
\text { deliberativo e elaboração de Plano de Salvaguarda }\end{array}$ \\
\hline & & $\begin{array}{l}\text { 2.2. Capacitação de quadros técnicos para a } \\
\text { implementação e gestão de políticas patrimoniais }\end{array}$ \\
\hline \multirow{3}{*}{ Eixo 3} & \multirow{3}{*}{ Difusão e Valorização } & 3.1. Difusão sobre o universo cultural do bem Registrado \\
\hline & & $\begin{array}{l}\text { 3.2. Constituição, conservação e disponibilização de } \\
\text { acervos sobre o universo cultural do bem Registrado }\end{array}$ \\
\hline & & \\
\hline
\end{tabular}




\begin{tabular}{|c|c|c|}
\hline & & 3.3. Ação Educativa para diferentes públicos \\
\hline & & 3.4. Editais e prêmios para iniciativas de salvaguarda \\
\hline & & $\begin{array}{l}\text { 3.5. Ampliação de mercado com benefício exclusivo dos } \\
\text { produtores primários dos bens culturais imateriais (ação } \\
\text { exclusiva para bens culturais cuja relação com o mercado } \\
\text { está posta no Dossiê de Registro como estruturante do } \\
\text { universo cultural em questão) }\end{array}$ \\
\hline \multirow{5}{*}{ Eixo 4} & \multirow{5}{*}{$\begin{array}{l}\text { Produção e Reprodução } \\
\text { Cultural }\end{array}$} & 4.1. Transmissão de saberes relativos ao bem Registrado \\
\hline & & $\begin{array}{l}\text { 4.2. Apoio às condições materiais de produção do bem } \\
\text { cultural Registrado }\end{array}$ \\
\hline & & $\begin{array}{l}\text { 4.3. Ocupação, aproveitamento e adequação de espaço } \\
\text { físico para Centro de Referência }\end{array}$ \\
\hline & & $\begin{array}{l}\text { 4.4. Atenção à propriedade intelectual dos saberes e } \\
\text { direitos coletivos }\end{array}$ \\
\hline & & $\begin{array}{l}\text { 4.5. Medidas administrativas e/ou judiciais de proteção } \\
\text { em situação de ameaça ao bem cultural Registrado }\end{array}$ \\
\hline
\end{tabular}

Tabela 1. Eixos de Ações de Salvaguarda do IPHAN. Fonte: Brasil, 2015c, pp. 7-8.

Dessa forma, o Livro de Registros é apenas uma etapa inicial do processo - que se atualiza constantemente através do planejamento e da execução dessas ações de salvaguarda. São elas que permitem um maior aprofundamento no estudo do bem em questão, a ampliação de atores envolvidos e, consequentemente, do entendimento de sua realidade. "Por questões inerentes as metodologias de pesquisa, a abrangência do bem cultural, a mobilização realizada durante a pesquisa, dentre outras, em geral a instrução do Registro não contempla todos os grupos ou comunidades detentoras do bem cultural" (BRASIL, 2015c, p. 4).

Além disso, como já foi dito, para garantir a constante atualização da situação do bem registrado, o Decreto $n^{\circ} 3551 / 2000$ prevê, em seu artigo $7^{\circ}$, que após dez anos da sua inscrição 
em um dos quatro livros, o bem cultural passe por um processo de reavaliação e revalidação do seu Registro. No caso dos processos aqui analisados, apenas o Ofício das Baianas de Acarajé está em processo de revalidação. Em setembro de 2015 foi empossado o Conselho Gestor da Salvaguarda do Ofício de Baiana de Acarajé. O grupo conta com representantes de 20 organizações diferentes, incluindo o IPHAN ${ }^{56}$.

A longa lista mostra a preocupação de atores de diversas esferas estarem envolvidos no processo de salvaguarda. Além disso, na mesma ocasião foi lançada uma das ações de divulgação do ofício: a plataforma Oyá Digital, que reúne em um mapa interativo $1.632^{57}$ baianas espalhadas por todo o país - e não só na Bahia. O site oferece a localização e informações de cada profissional. Além de poder buscá-las apenas clicando no mapa, ainda é possível pesquisar as baianas cadastradas no banco de dados por estado, cidade, gênero, raça ou religião.



Figura 20. Reprodução da plataforma Oyá Digital.

\footnotetext{
56 São representates: da Secretaria de Políticas de Promoção da Igualdade Racial - SEPPIR, da Associação Nacional das Baianas de Acarajé, Mingau, Receptivo e Similares - ABAM, da Associação Cultural de Preservação do Patrimônio Bantu - ACBANTU, do Ilê Axé Opô Afonjá, do Ilé Axé Mariolaje (Terreiro do Alaketu), do Instituto Palmares, do Coletivo de Entidades Negras - CEN, da Fundación Acua, do Instituto do Patrimônio Artístico e Cultural da Bahia - IPAC, do Centro de Culturas Populares e Identitárias da Secretaria de Cultura do Estado -CCPI/SECULT, da Secretaria de Promoção da Igualdade Racial - SEPROMI, da Secretaria do Trabalho, Emprego, Renda e Esporte - SETRE, da Secretaria Estadual de Políticas para as Mulheres - SPM, do Ministério Público do Estado da Bahia, da Secretaria Municipal de Ordem Pública - SEMOP, da Secretaria Municipal da Reparação - SEMUR, do Núcleo de Estudos Interdiciplinares Sobre a Mulher da Universidade Federal da Bahia - NEIM/UFBA e da Universidade Estadual da Bahia - UNEB. Disponível em http://iphanba.blogspot.de/2015/09/empossado-conselho-gestor-da.html. Consultado em 05 out. 2016.

${ }^{57}$ Disponível em www.oyadigital.com.br/. Consultado em 05 out. 2016.
} 
Já em relação ao Modo de Fazer do Queijo Artesanal de Minas, desde 2010, de dois em dois meses, há uma reunião da Salvaguarda do Queijo em Brasília, onde está sendo costurado um plano de salvaguarda. Além disso, algumas ações são desenvolvidas. Tivemos a oportunidade de participar como pesquisadora convidada, em abril de 2016, de uma das etapas do projeto: "Promoção de Ações de Salvaguarda do Modo Artesanal de Fazer Queijo de Minas”. Trata-se de um convênio firmado pelo IPHAN com o ITS - Instituto Terceiro Setor (uma instituição sem fins lucrativos) ${ }^{58}$ e desenvolvido em parceria com o Grupo de Trabalho de Queijos de Leite Cru do Slow Food. Iremos nos deter aqui um pouco nesse projeto, para entender melhor a dinâmica das ações de salvaguarda e sua complexidade.

O projeto tem por objetivo produzir informações sobre o universo da produção e consumo de queijos artesanais de leite cru, incluindo material fotográfico e audiovisual, que será base para a execução de três exposições itinerantes (uma para cada região produtora). Além disso, o acordo ainda prevê a confecção de material didático impresso, voltado para estudantes e produtores, a realização de Oficinas do Gosto (metodologia do Slow Food que será apresentada mais adiante neste trabalho) em escolas da rede pública local e apoio à participação de produtores em feiras e eventos gastronômicos em grandes centros consumidores como São Paulo, no Rio de Janeiro e Brasília.

Na etapa que participamos, foram realizados um seminário de dois dias sobre a situação do bem em questão, um grande encontro com produtores das três regiões e três dias de visitas a fazendas produtoras da Serra da Canastra, do Serro e do Salitre (Alto Paranaíba). Algumas das iniciativas que vêm sendo desenvolvidas pelos atores locais também puderam ser conhecidas. Como o projeto desenvolvido pela prefeitura de Medeiros nas escolas com os alunos do $9^{\circ}$ ano: o Tud'queijo. Os jovens foram estimulados a discutir o produto que suas famílias fabricam há gerações: criaram livros de receitas com fotos, fizeram vídeos reportando o processo de produção, entre outras atividades. O objetivo é incentivar nos mais novos o orgulho da cultura local. Aliás, o trabalho de educação para o patrimônio é uma das ações de salvaguarda do IPHAN, que desenvolveu, em outro projeto, a seguinte história em quadrinhos:

\footnotetext{
${ }^{58}$ Convênio no $811894 / 2014$.
} 


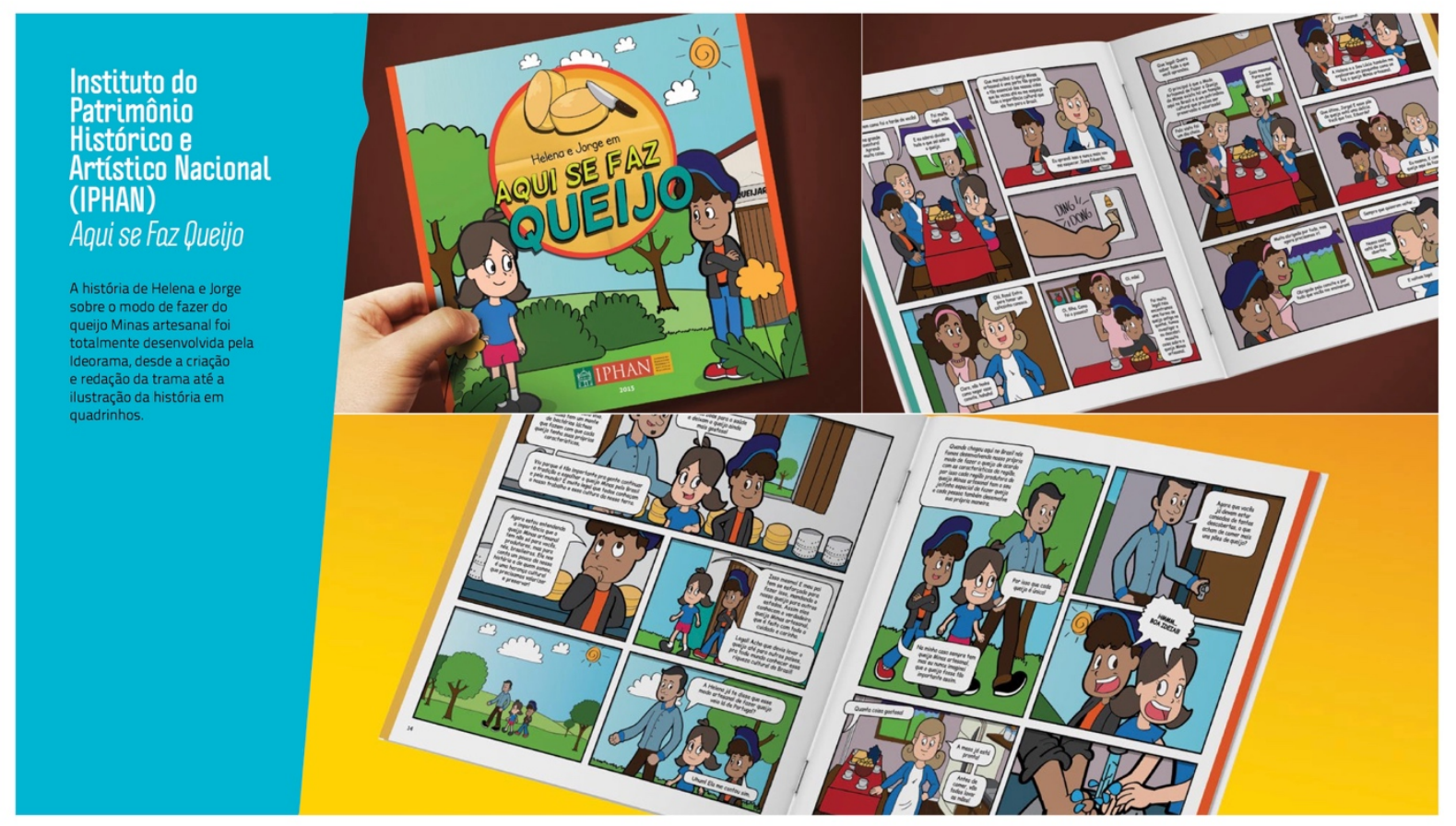

Figura 21. Reprodução do Catálogo da empresa Ideorama, responsável editorial do projeto. ${ }^{59}$

Em Medeiros, a prefeitura da cidade ainda promove anualmente a Feira Gastronômica do Queijo Canastra de Medeiros e estão planejando um museu ou Centro de Referência. Este último foi uma sugestão dos especialistas do IPHAN e Slow Food presentes. E corrobora com as instruções do Termo de Referência de Salvaguarda aqui discutido.

Em outra iniciativa, o Instituto Federal de Bambuí, através de um programa de extensão do Ministério da Educação, está planejando a criação de uma rota turística do Queijo da Canastra. Entre as propostas do projeto está a de que os produtores usem etiquetas de caseína (uma substância do leite que permite imprimir um selo no queijo sem comprometer o produto) para identificar seus queijos. Durante os testes, a aceitação dos turistas foi bastante animadora: os primeiros que um dos mais conhecidos produtores da Canastra usou, foram os primeiros a serem vendidos.

O fomento do turismo, aliás, foi apresentado por integrantes do IPHAN como uma boa ferramenta de promoção do ativo patrimonial local. No entanto, a maior parte dos especialistas em patrimônio presentes no encontro foram bastante críticos em relação às Indicações Geográficas - apresentada como um possível aliado nesse incentivo turístico. A grande questão

\footnotetext{
${ }^{59}$ Disponível em http://www.ideorama.com.br/ideo10anos/ideo10.pdf. Consultado em 05 out. 2016.
} 
apresentada por eles é que, ao contrário do processo do IPHAN, que busca incluir o máximo de atores, o do INPI é excludente. Isso porque ele exige que, para obter o selo, o produtor deve se enquadrar nas regras definidas pelo grupo que propôs a IG - o que teria um custo alto demais para os pequenos.

O que foi interessante notar, no entanto, é que, após essas discussões, ao ir ao encontro dos produtores, o grupo encontrou uma realidade diferente. Aqueles que se adequaram às regras do INPI e da Anvisa - que incluem automatização da ordenha, construção de queijaria à parte da casa, azulejada ou de pintura lavável, substituição de utensílios de madeira por alumínio, plástico ou ardósia (para as bancadas) ${ }^{60}$, entre outras - se disseram felizes com as mudanças. $\mathrm{O}$ discurso de muitos deles é, inclusive, de que o queijo melhorou. O que se percebe, no entanto, é que a certificação abre mercados e valoriza o produto - possibilitando que essas pequenas famílias produtoras (em geral casal, ou casal e filhos), possam melhorar suas condições de vida.

Outra percepção levantada pelo grupo de pesquisadores é a de produtores que haviam deixado o campo e retornaram para o queijo, motivados pelo mercado que se mostra mais atrativo com o turismo e a premiação recebida pelo Queijo do Guilherme na França ${ }^{61}$. No entanto, também foi detectado que esse mercado de queijos maturados ainda é novo - a maior parte vende e consome o queijo fresco. Discussões de gênero e saúde no campo, autossuficiência de produtores, dependência de queijeiros, entre outros temas também foram levantados.

Fica evidente, a partir da experiência em uma etapa desse projeto (que segue até 2017), a necessidade de discussões constantes entre os atores locais e os diferentes grupos sociais e institucionais. Conforme debatido anteriormente - e de acordo com os pré-requisitos do próprio IPHAN, essa integração é fundamental, para que se possa derrubar ideias pré-concebidas e distâncias de perspectivas e que assim se consiga garantir a construção de um plano de

\footnotetext{
${ }^{60}$ A discussão acerca da substituição dos utensílios de madeira pelos de plástico, metal e pedra vai para além do custo financeiro que impacta o pequeno produtor. Trata-se do custo cultural: da substituição de tecnologias que vêm sendo utilizada há anos sem comprometer a segurança alimentar da população que consome o produto. A professora Célia Lucia Ferreira (Universidade Federal de Viçosa - UFV) argumenta que a única forma de combater as leis higienistas é através de pesquisas científicas que comprovem sua invalidade. Assim, ela apresentou um estudo desenvolvido com produtores de queijo artesanal da Serra da Canastra e do Serro em 2013 que mostra que o uso da madeira não é determinante para a contaminação do queijo, mas a qualidade do leite e os cuidados de higiene (GALINARI, 2014). As pesquisas apontam para o fato que o ambiente extremamente esterilizado modifica a gama de micróbios que atuam no desenvolvimento do queijo de leite cru - um alimento vivo. Experiências têm apontado, explica a professora, para os riscos de contaminação nesses ambientes sem defesas. No entanto, são necessárias mais pesquisas para que se tenha dados confiáveis - e, para isso, investimentos, que têm sido muito escassos.

${ }^{61}$ O produtor Guilherme Ferreira, da Estância Capim Canastra, teve o seu queijo premiado com a medalha de prata entre os queijos de massa dura, em competição mundial que ocorreu em 2015, em Tours, na França. Voltaremos ao caso dele e os efeitos da premiação na região em nossa discussão final.
} 
salvaguarda que abarque toda a complexidade do bem registrado. Dessa forma, retomamos a discussão do segundo capítulo, com Hjalager; Richards, (2002), Scarpato (2002), Espeitx (2004), Dória (2014) e Krippendorf (2000), de que o turismo pode se apresentar como uma das ferramentas de salvaguarda da cultura alimentar nacional, ao invés de sofrer resistência por ser considerado um fenômeno que causa desequilíbrios socioculturais.

\section{INPI}

Ao contrário do IPHAN e do Slow Food, o INPI não conta com ações extras após a concessão da Indicação Geográfica. "Formalmente o trabalho do INPI se encerra, mas normalmente conversamos com os agrupamentos sobre potenciais incrementos e alteração nas indicações geográficas concedidas", explica Raul Bittencourt. O que se observa é um maior suporte por parte do SEBRAE e outros parceiros, que auxiliam os produtores com planos de negócios e desenvolvimento de identidade visual - preparando-os para aproveitar a valorização gerada pelo selo de IG. Atualmente, o turismo ainda é trabalhado em poucos projetos, mas há planos do SEBRAE de incentivar mais esse aspecto em todas as IGs.

\section{SLOW FOOD}

Como já foi posto anteriormente, a Arca do Gosto, processo de inventariação do Slow Food aqui analisado é apenas uma das ações desenvolvidas pelo movimento internacional em defesa da biodiversidade. Ele se articula com outros diversos projetos da instituição. O primeiro e principal é o Fortalezas Slow Food. Trata-se de uma sequência da catalogação de bens na Arca: quando se aprofunda mais na situação do produto e produtores, desenvolvendo projetos de valorização e promoção do alimento no mercado. É necessário ressaltar que, a priori, esse projeto faria parte da presente análise. No entanto, por uma questão de ausência dos produtos já analisados nos demais inventários, entendeu-se que não caberia esse aprofundamento aqui. Apesar de não serem parte de um projeto de Fortalezas, os queijos recebem atenção e ações especiais dentro de um outro braço do movimento: o Grupo de Trabalho (GT) do Queijo de Leite Cru, já mencionado no relato da ação de Salvaguarda do Modo Artesanal de Fazer Queijo de Minas, do IPHAN.

Uma das propostas mais recentes do Slow Food Internacional é a Aliança de Cozinheiros. Lançada oficialmente no Brasil em 2016, ela propõe identificar os profissionais da cozinha que trabalham respeitando os valores do movimento de um alimento bom, limpo e justo. Um dos objetivos é, através dos chefs de cozinha, promover uma valorização de produtos locais em risco de desaparecimento - os produtos da Arca do Gosto e do Fortalezas. Esses profissionais têm para isso uma logo que podem utilizar e indicam em seus cardápios os produtos dos inventários mencionados, além dos produtores. Em São Paulo, desde 2015, o 
grupo promove anualmente o Festival Arca do Gosto (veja as imagens abaixo), no qual cada restaurante participante cria um prato com pelo menos um item da catalogação do Slow Food, trazendo maior divulgação para o projeto.
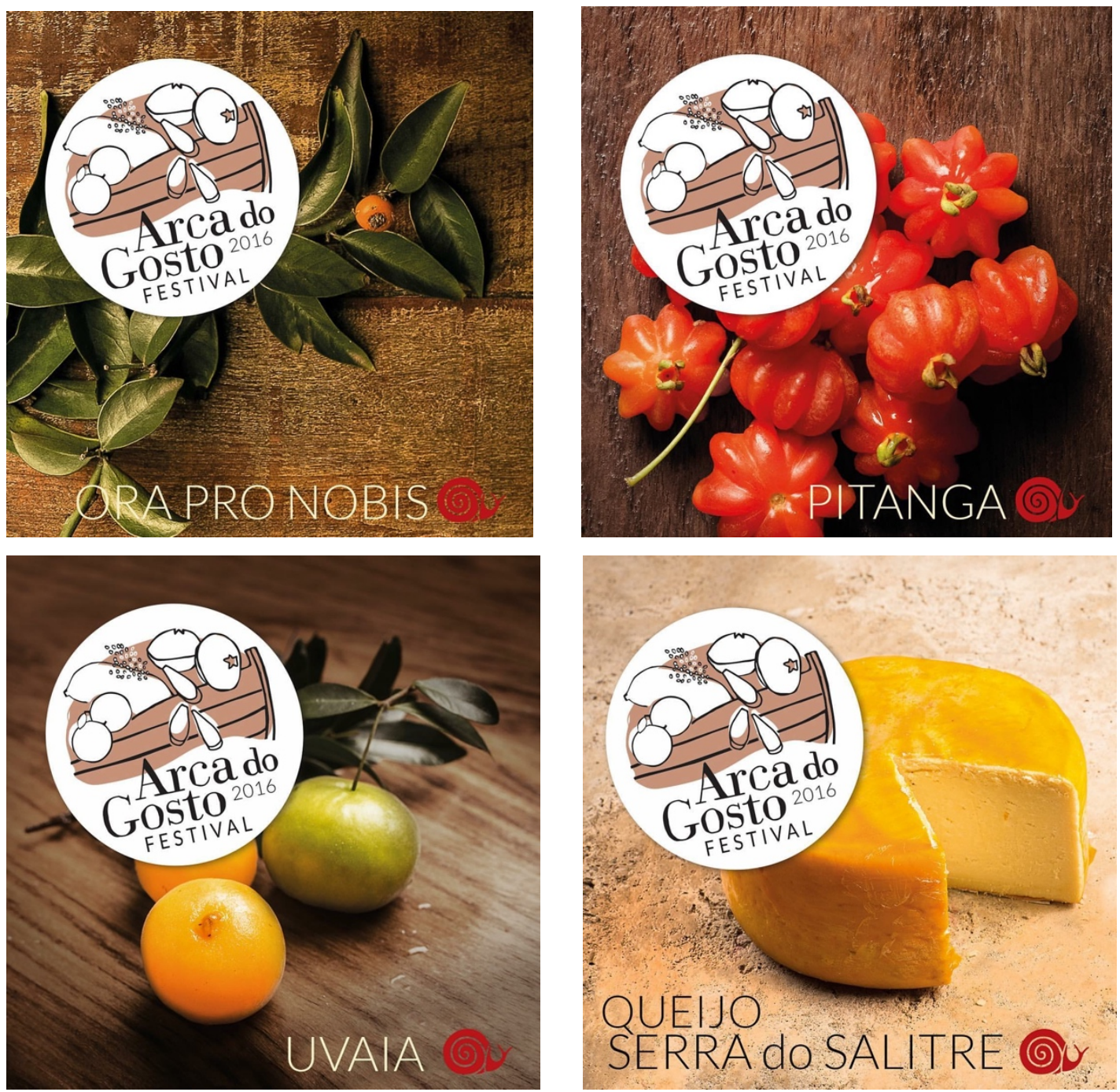

Figura 22. Reprodução de divulgação do Festival Arca do Gosto de 2016. Slow Food Brasil.

Outra vertente fortemente conectada aos dois inventários são as Comunidades do Alimento. Trata-se de um projeto de identificação e apoio aos grupos que fazem, de alguma forma, parte do elo da cadeia de alimentos tradicionais, e que compartilham da filosofia do movimento. Essas comunidades podem ser de dois tipos: de Território - "a comunidade produz vários produtos, até diferentes entre si, mas todos ligados a uma área geográfica delimitada ou a uma etnia indígena"62; e de Produto - "a comunidade é composta por todos os agricultores/criadores, transformadores e distribuidores que contribuem, de várias formas, na

\footnotetext{
${ }^{62}$ Disponível em http://www.slowfoodbrasil.com/comunidades-do-alimento. Consultado em 06 out. 2016.
} 
produção de um determinado produto proveniente de um território específico" ${ }^{\natural 3}$. No Brasil, existem atualmente 116 comunidades registradas.

Esse é um dos projetos do Slow Food Itália que está mais interligado ao turismo, de certa forma, uma vez que essas comunidades do alimento fazem parte dos guias desenvolvidos pelo movimento desde a década de 1990 e que impulsionaram um novo turismo gastronômico no continente europeu, conforme discutido no capítulo 2. Nessa perspectiva, aliado à Arca do Gosto e ao Fortalezas, ele pode ser uma das ferramentas de impulsão para novos projetos que envolvam o desenvolvimento do turismo gastronômico no Brasil, como as rotas alimentares, aqui também já discutidas.

A Educação do Gosto, tema de um dos Grupos de Trabalho do movimento no país, é outra das abordagens de valorização dos produtos da biodiversidade local. Os profissionais da educação em diversos níveis e campos trabalham desde o contato de crianças com a terra, no manejo de hortas escolares, até workshops com pais e merendeiras, para discutir como aproveitar a diversidade local na alimentação das crianças. Uma das metodologias que é trabalhada com todas a idades é a Oficina do Gosto: uma dinâmica de reflexão das memórias alimentares, que conta com um percurso sensorial que desafia os participantes a identificarem elementos de sua cultura alimentar pelo tato, olfato, visão, audição e paladar. Um exemplo desta metodologia, desenvolvido em Bambuí-MG, em abril de 2016, voltado para produtores de queijo de leite cru, pode ser observado na Figura 23.

Ainda no campo da educação, a Unisig - Universidade de Ciências Gastronômicas do Slow Food, que fica em Bra, na Itália, começou a desenvolver um projeto denominado Celeiros da Memória. Os estudantes documentam em vídeo, foto e texto, suas viagens de campo pelo mundo, identificando pequenos produtores, possíveis comunidades de alimento, novos itens para a Arca do Gosto e registrando suas memórias alimentares.

\footnotetext{
${ }^{63}$ Idem.
} 


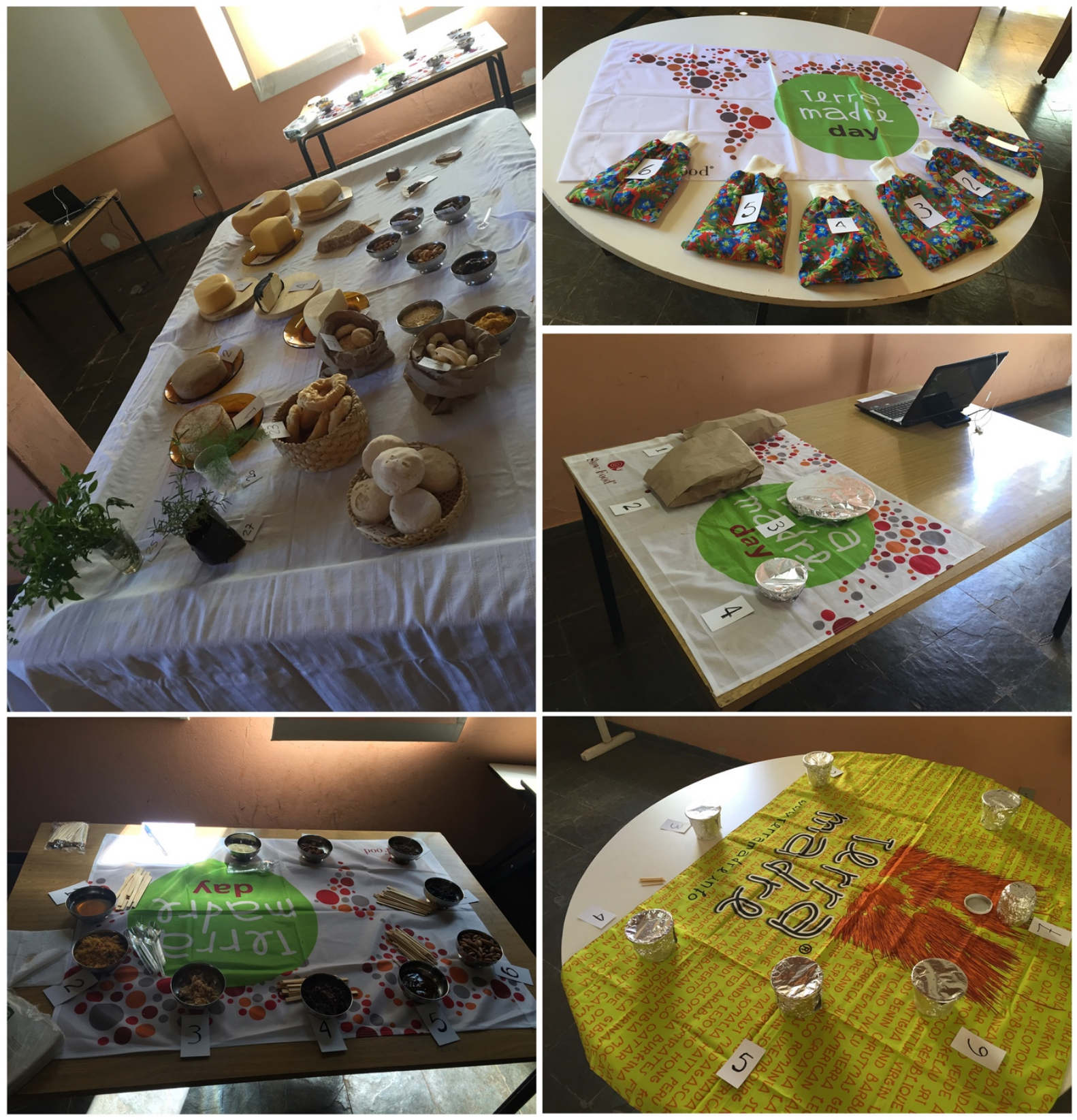

Figura 23. Oficina do Gosto desenvolvida durante o projeto do GT do Queijo em convênio com o IPHAN em abril de 2016, em Bambuí-MG. Em sentido horário: tato, audição, olfato, paladar e visão. Fotos: Thalita Kalix G. Santana.

Já em relação ao turismo, a organização internacional está implementando dois novos projetos: o Slow Food Planet e o Slow Food Travel. O primeiro é um aplicativo de celular, lançado em 2015, que compila dicas de produtos, restaurantes, mercados, feiras e produtores alinhados à filosofia em algumas cidades do mundo. No Brasil apenas o Rio de Janeiro por enquanto está disponível. Já o segundo é um projeto piloto, proposto no Terra Madre 2016. O objetivo é criar destinações Slow Food - isto é, com experiências de conhecer e pôr a mão na massa com pequenos produtores locais, e, nos intervalos, tomar café da manhã, almoçar ou jantar em estabelecimentos que valorizem a cultura alimentar da região. A primeira destinação é uma pequena região no interior da Áustria, chamada Caríntia, que, depois de dois anos de 
desenvolvimento do piloto, começa a receber seus primeiros turistas. No Brasil há projetos que já vêm sendo desenvolvidos de forma semelhante, que necessitariam de poucos ajustes para fazer carregar esse selo.

Por fim, o Slow Food Brasil assinou, em 2015, um convênio com o então Ministério do Desenvolvimento Agrário (MDA) - no atual governo se tornou uma secretaria especial - que visa articular e fortalecer a Agricultura Familiar. O projeto, que será desenvolvido em parceria com uma rede de universidades lideradas pela UFSC e durará três anos, tem cinco metas: catalogar 150 novos produtos para a Arca do Gosto (sendo 30 de cada região administrativa do Brasil); inserção de novas e fortalecimento das atuais Fortalezas do país; ampliar o número de Comunidades do Alimento; inserção dos produtos da Agricultura Familiar no mercado; e capacitação de jovens para a ecogastronomia.

A estratégia, aliás, de aliar editais de órgãos públicos com os projetos do movimento é uma das principais formas de se garantir financiamento, uma vez que a rede internacional é formada por voluntários. "Como Slow Food não conseguiremos tornar todos os produtos da Arca do Gosto em Fortalezas. Por isso é importante ter outras ações e aglutinar mais atores na proteção desses produtos", justificou Andrea Pieroni, professor da Unisig e colaborador técnico da Fundação Slow Food pela Biodiversidade, em Fórum que ocorreu no dia 25 de setembro de 2016, em Turim, Itália, como parte da programação do Terra Madre 2016.

\subsection{DIFERENTES INVENTÁRIOS: RELAÇÕES POSSÍVEIS?}

Ao analisarmos cada um dos três processos de inventariação, ficam claras as diferenças entre eles. Primeiramente metodológicas. O IPHAN tem uma abordagem mais acadêmica, com pesquisas históricas, antropológicas e sociológicas. Já o INPI constrói seus dossiês com uma abordagem jurídica e econômica predominante. Por fim, o Slow Food tem uma metodologia bastante aberta, sem grandes padronizações. Cada uma delas condiz com as intencionalidades dos respectivos registros. O detalhamento das fichas de candidatura, dos dossiês e das ações extras torna perceptível os objetivos e as ferramentas utilizadas para atingi-los por cada uma das instituições.

O primeiro bem analisado, o Ofício das Baianas de Acarajé, do IPHAN, não se repete em nenhum dos outros dois inventários. E essa ausência nos permite algumas reflexões. Um certificado de Indicação Geográfica do INPI seria possível se levarmos em conta que as IGs abrangem também serviços. No entanto, a definição de uma limitação geográfica seria complicada. Como mostra o projeto do IPHAN, Oyá Digital, há baianas de acarajé por todo o país. Além disso, o INPI nunca recebeu nenhum pedido de registro nesse sentido. 
Já uma candidatura do mesmo bem para a Arca do Gosto seria impossível. Primeiramente não poderia ser do Ofício, mas teria de ser do produto, o acarajé. No entanto, o bolinho de feijão frito seria considerado uma receita e não um produto, o que impediria fazer parte da catalogação. Essa é uma discussão que aproxima o IPHAN do Slow Food. Em nenhuma das instituições receitas podem fazer parte dos registros. A justificativa acerca da Arca do Gosto é que a catalogação tem como intuito de preservar a biodiversidade e para isso reconhece produtos. Nessa categoria entram produtos processados, ou seja, queijos, pães, conservas - técnicas desenvolvidas para preservar produtos frescos, mas não receitas, produtos feitos para consumo imediato.

Já para o IPHAN, o reconhecimento de receitas distorceria o objetivo do processo de salvaguarda:

[...] o DPI entende que o instrumento do Registro não se destina ao reconhecimento de receitas de comida (ou de modos de fazer determinado produto) segunda padrões de autenticidade e originalidade. As comidas - seu preparo e consumo - são contempladas enquanto saberes e fazeres construídos nos processos de sobrevivência, de apropriação e transformação dos recursos naturais, enquanto formas de sociabilidade reiteradas em festas e celebrações, ou como práticas coletivas enraizadas no cotidiano de grupos sociais e que constituem referências culturais para esses grupos. (BRASIL, 2005, pp. 2-3)

Assim, os bens aqui analisados salvaguardados pelo IPHAN tiveram como proposta inicial apenas o produto final - e, sob orientação da Câmara do Patrimônio Imaterial, passaram a abranger todo um sistema em torno desses produtos.

As diferenças de abordagens dos três processos de inventariação ficam bem claras nos casos dos queijos de Minas e da cajuína. Em relação à produção artesanal dos queijos da Canastra e do Serro (os dois com Indicação de Procedência), as críticas de especialistas tanto do IPHAN quanto do GT de Queijos do Slow Food se concentram no caráter excludente da certificação do INPI - uma vez que só tem direito a ela o produtor que se integra ao grupo (associação ou cooperativa) responsável pelo regulamento de uso da IG. As adequações que o pequeno produtor tem que passar para se enquadrar podem ser bastante dispendiosas, o que as torna inacessível para alguns.

Há uma percepção diferente sobre as cadeias, ao passo que nossos colegas do IPHAN querem estimular determinadas cadeias para expandi-las e disseminar o conhecimento, as indicações geográficas por muitas vezes se valem da própria "raridade", da escassez de um produto para aumentar a margem de lucro dos produtores. Não há grandes conflitos, mas são aspectos diferentes sobre agrupamento, o produto e a produção. ${ }^{64}$

\footnotetext{
${ }^{64}$ Raul Bittencourt Pedreira, um dos responsáveis pelas IGs no INPI, em entrevista feita por escrito, em 28 de setembro de 2016.
} 
Outro ponto de discordância entre as instituições é a avaliação de que as IGs são muito voltadas para o mercado, sem preocupações com a salvaguarda cultural - crítica essa rebatida pelos atores envolvidos com as Indicações Geográficas, porém reforçada pelo discurso predominante nos dossiês do INPI. Exemplo desse conflito é o caso da cajuína. As ações de padronização da produção estimuladas pelo SEBRAE (parceiro do INPI) incluem processos de higienização dos cajus com água (o que vai contra a cultura de lavá-lo na água de caju), acréscimo de uma etapa de pré-aquecimento e, principalmente, a busca pela homogeneização dos produtos (com uso inclusive, de caju clonado). Apresenta-se assim o grande choque de perspectivas. Enquanto nos documentos do IPHAN e do Slow Food a diversidade de cores e sabores é o que agrega qualidade à cajuína, garantindo que essa cultura persista, na coleção de documentos do INPI é a possibilidade de padronização e aumento da escala de produção que são apontados como fundamentos de um produto de qualidade excepcional. Essas modificações são vistas como risco à salvaguarda desse saber, apontado no dossiê do IPHAN.

Com perspectivas tão diferentes entre esses inventários há relação possível? Acreditamos que sim. O que se observa é que as aproximações entre as instituições existem pontualmente - dependem dos atores de cada uma delas envolvidas. Mesmo que tenham objetivos diferentes, é viável aliar as estratégias de divulgação dos bens em questão através do diálogo. Nos casos aqui estudados, percebe-se que o selo de IP traz ainda mais ganho de valor para os queijos. E boa parte dos produtores envolvidos com os processos de salvaguarda do IPHAN, aprovam e se não o têm ainda, pretendem tê-lo.

Já no caso da cajuína, o conflito é maior. A padronização da matéria prima e do modo de fazer e, consequentemente do produto, ameaça a produção artesanal - que tem sempre diferentes produtos conforme o produtor. No queijo, o pingo, as vacas, a alimentação são fatores que garantem a variedade de sabores no fim das contas. Na cajuína a matéria prima, as diferentes técnicas de filtragem, o tempo do banho maria, etc. também influem em uma bebida única como resultado.

Assim, tornar o bem do patrimônio alimentar um produto mais atrativo para o mercado pode ser uma das ferramentas de salvaguarda. No entanto, é necessário que essa relação seja construída baseada em diálogo entre as instituições e os produtores - os atores principais desses inventários, no fim das contas. Retomamos aqui o debate desenvolvido no capítulo anterior, de que esse é o caminho que se aponta para que se possa pensar em um turismo mais "sustentável". A valorização da gastronomia local, não apenas um atrativo simplificado, mas como um sistema cultural complexo, com diversas facetas (e atrações) apresenta-se como uma solução possível 
para o desenvolvimento do turismo no Brasil. Mas será que as políticas públicas desenvolvidas no país levam isso em conta? Esse é o ponto que desenvolveremos a seguir.

\subsection{AS POLÍTICAS PÚBLICAS E OS INVENTÁRIOS: UMA PERSPECTIVA PARA O TURISMO BRASILEIRO?}

Debatemos até aqui o percurso de formação de uma noção de gastronomia brasileira, os processos de inventariação do Patrimônio Alimentar nacional e sua importância para a Salvaguarda da cultura, memória e identidade das populações que formam o país. Além disso, analisamos como o IPHAN, o INPI e o Slow Food desenvolvem seus inventários no Brasil, suas intencionalidades e resultados, sua ligação com o turismo e como dialogam, ou ainda pouco dialogam entre si. Voltamos, neste último capítulo às nossas perguntas iniciais: há atualmente no Brasil uma política pública de incentivo ao turismo gastronômico? Há alguma relação entre os diferentes inventários do patrimônio alimentar nacional e o fomento do turismo no país?

Para alicerçar nossa busca por essas respostas, propôs-se a analisar ações e projetos desenvolvidos pelos ministérios do Turismo (MTur), da Cultura (MinC) e do Desenvolvimento Agrário (MDA) ${ }^{65}$ que envolvam o incentivo ao turismo gastronômico no Brasil para verificar se tais inventários são utilizados com esse propósito. Inicialmente, definimos o recorte dos últimos cinco anos como referência. Entretanto, durante o processo de levantamento documental, se percebeu mais relevante tratar de políticas que estejam sendo desenvolvidas atualmente. Isso não exclui que possamos apresentar ainda projetos que tenham sido desenvolvidos num passado recente e tenham sido descontinuados. Mas, dessa forma, optamos por focar, no estudo em tela, no diagnóstico da situação atual para que se possa pensar em perspectivas para o futuro.

Nesta fase de nossa análise, a documentação que examinamos é bastante diversa. Retomamos, para tanto, a definição de documento apresentada no capítulo anterior e que baseia esta pesquisa: qualquer vestígio do passado, que sirva como testemunho (CELLARD, 2012), produtos sociais que expressam uma estrutura, construídos conforme regras específicas (PRIOR, 2003), qualquer fonte de informação (LAVILLE; DIONNE, 199). Nessa perspectiva, integram nossa base analítica reportagens, estudos de casos, manuais, sites dos ministérios em questão, legislações, etc. Dois pontos nos fizeram optar por atermo-nos a publicações oficiais.

\footnotetext{
${ }^{65}$ Durante o processo de construção desta pesquisa, o MDA deixou de ser um Ministério, tornando-se uma secretaria especial, ligada à Casa Civil. No entanto, nos referiremos ao longo do texto ainda à sigla antiga, sob a qual as ações aqui abordadas foram desenvolvidas.
} 
O primeiro é o da credibilidade. Dessa maneira asseguramos a veracidade das informações. O segundo é o da possibilidade de extrair de um documento, ao analisar todo o seu contexto, as suas intencionalidades, o discurso que o rege - e, dessa forma, poder analisar mais fidedignamente o discurso das instituições em questão. Como no capítulo anterior, as análises serão aqui apresentadas primeiramente divididas por ministério, para, na sequência, serem comparadas.

\section{Ministério da Cultura}

Tendo o IPHAN, instituição cujo processo de inventariação do patrimônio alimentar brasileiro aqui analisamos, como uma autarquia federal vinculada a si, o Ministério da Cultura é um dos órgãos com maior ligação com a salvaguarda da cultura alimentar nacional. Além das ações desenvolvidas pelo IPHAN, no entanto, a culinária brasileira ainda figura em outros projetos. Uma das principais é a Política Nacional de Cultura Viva, desenvolvida pela Secretaria da Cidadania e Diversidade Cultural. Instituída em julho de 2014 pela Lei no 13.018, ela simplifica os processos de prestação de contas e o repasse de recursos para as organizações da sociedade civil, responsáveis pelos Pontos de Cultura.

Trata-se de um programa de certificação e repasse de verbas do MinC para entidades ou coletivos culturais, que desenvolvem e articulam atividades culturais em suas comunidades e em redes.

O reconhecimento como Ponto ou Pontão de Cultura garante uma chancela
institucional, que pode ser importante para a obtenção de apoios e parcerias, e
permite que a entidade ou coletivo se articule com os outros pontos e pontões
da rede, a partir de afinidades temáticas ou do pertencimento a um território.
Os Pontos e Pontões de Cultura também podem receber apoio financeiro
através de editais públicos do governo federal, estados e municípios. Os
instrumentos de fomento para os Pontos de Cultura podem ser prêmios, bolsas,
ou o Termo de Compromisso Cultural (TCC), instrumento específico de
repasse de recursos da Política Nacional de Cultura Viva. ${ }^{66}$

Em consulta através do programa de acesso à informação, tivemos acesso aos dados de que haviam, em março de 2016, 78 pontos relacionados com Gastronomia e Culinária. A maior parte, no entanto, não é voltada exclusivamente para a alimentação, mas a abarcam juntamente com outras manifestações culturais. Da mesma forma, outros programas de apoio à cultura, como a Lei Rouanet (Lei 8.313 de 1991), contemplam projetos que envolvam as tradições alimentares. Não há no MinC, no entanto, nenhum projeto com foco exclusivamente na cultura alimentar nacional.

\footnotetext{
${ }^{66}$ Disponível em http://www.cultura.gov.br/culturaviva/ponto-de-cultura/apresentacao. Consultado em 25 out.
} 2016. 


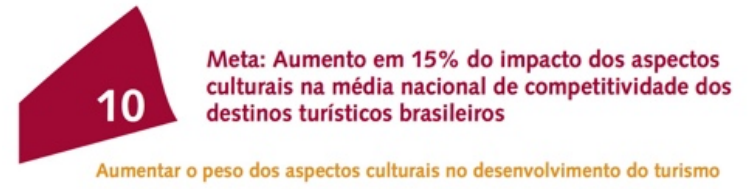

As caracteristicas culturais de uma cidade ou região são fundamentais para o desenvolvimento do turismo local.

O Ministério do Turismo estabeleceu um Índice de Competitividade para avaliar os 65 principais destinos turisticos do Brasil. Essa avaliação atribui uma nota a 13 dimensōes, entre as quais a infraestrutura geral, o marketing e os aspectos culturais.

A dimensăo dos aspectos culturais abrange a produção cultural do destino associada ao turismo, a preservação do patrimônio histórico e cultural e a estrutura municipal para o apoio à cultura.

O que se pretende alterar na situação atual?

Num periodo recente, os aspectos culturais das cidades têm ganhado força como atraçăo nos principais destinos turisticos brasileiros. Mesmo assim, a nota desses aspectos ainda está em 55,9; numa escala que vai de 0 a 100 . A partir de agora, o que se pretende é melhorar, nesses destinos, a produção cultural associada ao turismo, a preservaçāo do patrimônio histórico e cultural e a estrutura municipal para o apoio à cultura. A melhoria deverá se refletir na nota dos aspectos culturais, com aumento de $15 \%$, isto é, de 55,9 para 64,3 .

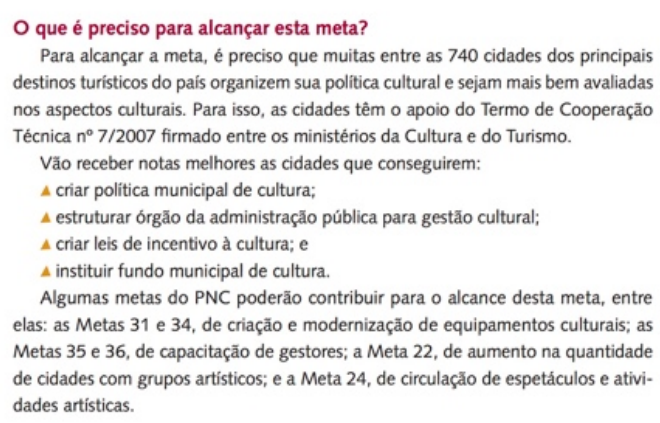
destinos turisticos do pais organizem sua politica cultural e sejam mais bem avaliadas nostinos turisticos do pais organizem sua polititca cultural e sejam mais bem avaliadas Técnica $n^{\circ} 7 / 2007$ firmado entre os ministérios da Cultura e do Turismo.

Vão receber notas melhores as cidades que conseguirem:

$\triangle$ criar politica municipal de cultura;

$\Delta$ estruturar órgão da administraçăo pública para gestão cultural:

$\triangle$ criar leis de incentivo à cultura; $\mathrm{e}$

$\Delta$ instituir fundo municipal de cultura.

Algumas metas do PNC poderão contribuir para o alcance desta meta, entre elas: as Metas 31 e 34, de criaçăo e modernização de equipamentos culturais; as Metas 35 e 36, de capacitaçăo de gestores; a Meta 22, de aumento na quantidade de cidades com grupos artísticos; e a Meta 24, de circulaçăo de espetáculos e atividades artísticas.

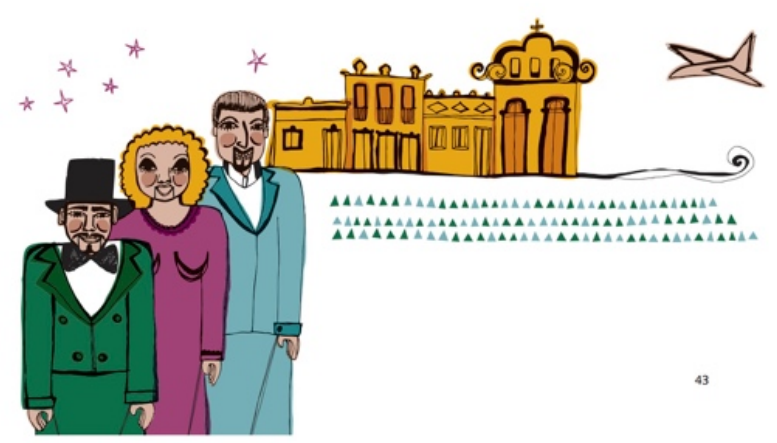

Figura 24. Reprodução de página da publicação 'As metas do Plano Nacional de Cultura' (BRASIL, 2012).

A relação com o turismo também não é sistemática. Já houveram acordos de cooperação técnica entre os dois ministérios (MinC e MTur), com foco em projetos específicos. Não se percebe, no entanto, uma política de cooperação constante. Ao contrário, é possível notar, utilizando o exemplo dos inventários do Patrimônio Alimentar do IPHAN, que ainda se vale pouco do potencial do turismo para a salvaguarda cultural. Mas há perspectivas. No Plano Nacional de Cultura, aprovado em 2010, e que contém 53 Metas para 2020, cinco delas podem ser relacionadas ao desenvolvimento do Turismo Gastronômico do país. São elas:

- Meta 3 Cartografia da diversidade das expressões culturais realizada em todo o território brasileiro - Produzir um mapa das expressões culturais e linguagens artísticas de todo o Brasil

- Meta 4 Política nacional de proteção e valorização dos conhecimentos e expressões das culturas populares e tradicionais implantada - Ter leis que valorizem e protejam as culturas populares e tradicionais

- Meta 5 Sistema Nacional de Patrimônio Cultural implantado, com 100\% das Unidades da Federação (UFs) e 60\% dos municípios com legislação e política de patrimônio aprovadas - Ter leis e políticas de patrimônio cultural aprovadas em todos os estados e em 3.339 cidades do Brasil (60\%)

- Meta $650 \%$ dos povos e comunidades tradicionais e grupos de culturas populares que estiverem cadastrados no Sistema Nacional de Informações e Indicadores Culturais (SNIIC) atendidos por ações de promoção da diversidade cultural - Garantir que um número maior de povos e comunidades 
tradicionais e grupos de culturas populares sejam atendidos por ações públicas de promoção da diversidade cultural

- Meta 10 Aumento em 15\% do impacto dos aspectos culturais na média nacional de competitividade dos destinos turísticos brasileiros - Aumentar o peso dos aspectos culturais no desenvolvimento do turismo (BRASIL, 2012, pp. 26-43)

Mesmo que o turismo só seja mencionado na última meta apresentada, pode-se perceber que as outras quatro são potenciais para ações em conjunto. Falta, de toda maneira, uma política contígua das duas pastas.

\section{Ministério do Desenvolvimento Agrário}

O MDA tem uma relação estreita com o desenvolvimento da Arca do Gosto no Brasil. Isso porque o ministério foi peça fundamental na fixação do Slow Food no país. Mesmo existindo um convívio de associados no Rio de Janeiro desde 2000, o Slow Food Brasil só é fundado oficialmente em 2004, em um caso único na história do movimento internacional, uma vez que este se estabelece aqui através da assinatura de um acordo de cooperação diretamente com o Governo Federal (GENTILE, 2016).

$\mathrm{O}$ acordo tem por objetivo estabelecer as bases de cooperação entre os participantes, para a promoção e integração de políticas públicas em prol da preservação e valorização dos alimentos típicos, em territórios onde se concentram os agricultores familiares e assentados do Brasil. As atividades previstas para fazer isso são: criação de Fortalezas Slow Food no Brasil; identificação de produtos nativos e artesanais, para a Arca do Gosto; apoio aos produtores das Fortalezas para participarem em eventos promovidos pelo Slow Food e pelo MDA; identificação das Comunidades do Alimento, para integrarem a rede Terra Madre. Os projetos são desenvolvidos por meio da Secretaria de Desenvolvimento Territorial (SDT) do Ministério do Desenvolvimento Agrário (MDA) (GENTILE, 2016, p. 84).

Dessa forma, o movimento dá os seus primeiros passos no país já contando com uma estrutura governamental para apoiá-lo e não apenas dependendo das ações de voluntários. Gentile explica ainda que a expertise dos italianos também é utilizada na parceria, de forma a desenvolver projetos pensados para os pequenos agricultores brasileiros.

É o experimento do conúbio entre um movimento social e o governo. O acordo, no entendimento das partes, servirá para proporcionar aquele apoio de cima e a adoção de políticas públicas condizentes, necessários a um proceder integrado e orgânico, isto é, capaz de garantir uma eficácia sistêmica. Eficácia da qual, pelo contrário, ações esporádicas baseadas apenas no voluntarismo e no ativismo espontâneo, geralmente, estão desprovidas. (GENTILE, 2016, p. 92).

De 2004 a 2008, Luigi Eusebi, Gabrio Marinozzi e Roberta Sá são a ponte entre o movimento internacional e o governo brasileiro e têm papel fundamental no desenvolvimento dos projetos do Slow Food em parceria com o MDA. Entretanto, com a saída desses atores 
chaves do ministério, percebe-se uma queda no ritmo de crescimento. Em 2014 é fundada a Associação Nacional Slow Food Brasil, permitindo ao movimento no país um maior grau de independência da sede italiana para estabelecer acordos. A partir de novembro do mesmo ano, “[...] o movimento conta também com um consultor específico dentro do MDA (Secretaria de Agricultura Familiar, Departamento de Geração de Renda e Agregação de Valor), contratado exclusivamente para acompanhar e executar os projetos do Slow Food no Brasil" (GENTILE, 2016, p. 91)

Por fim, conforme já descrito no capítulo anterior, em 2015 a associação nacional assinou um novo convênio com o MDA que visa articular e fortalecer a Agricultura Familiar. O projeto, que será desenvolvido em parceria com uma rede de universidades lideradas pela UFSC e durará três anos, tem cinco metas: catalogar 150 novos produtos para a Arca do Gosto (sendo 30 de cada região administrativa do Brasil); inserção de novas e fortalecimento das atuais Fortalezas do país; ampliar o número de Comunidades do Alimento; inserção dos produtos da Agricultura Familiar no mercado; e capacitação de jovens para a ecogastronomia.

Além dessa extensa parceria com o Slow Food, o MDA possui ainda outros projetos e ações que se relacionam a turismo e gastronomia. Entre eles destacam-se os programas de Selos de origem: da Agricultura Familiar, Quilombos do Brasil, Indígenas do Brasil e Origens Brasil. Todos os quatro projetos apresentam uma semelhança de proposta com as Indicações Geográficas do INPI: elas têm como objetivo agregar valor ao produto comercializado, indicando a população e o território de onde vêm. O que muda é que estas certificações são dadas às comunidades, que produzem uma gama variada de produtos, de alimentos in natura, a processados e artesanato. Tratam-se, no entanto, de projetos em fase inicial, lançados em 2015, que ainda têm de se estabelecer e serem continuados para gerarem efeitos duradouros. 


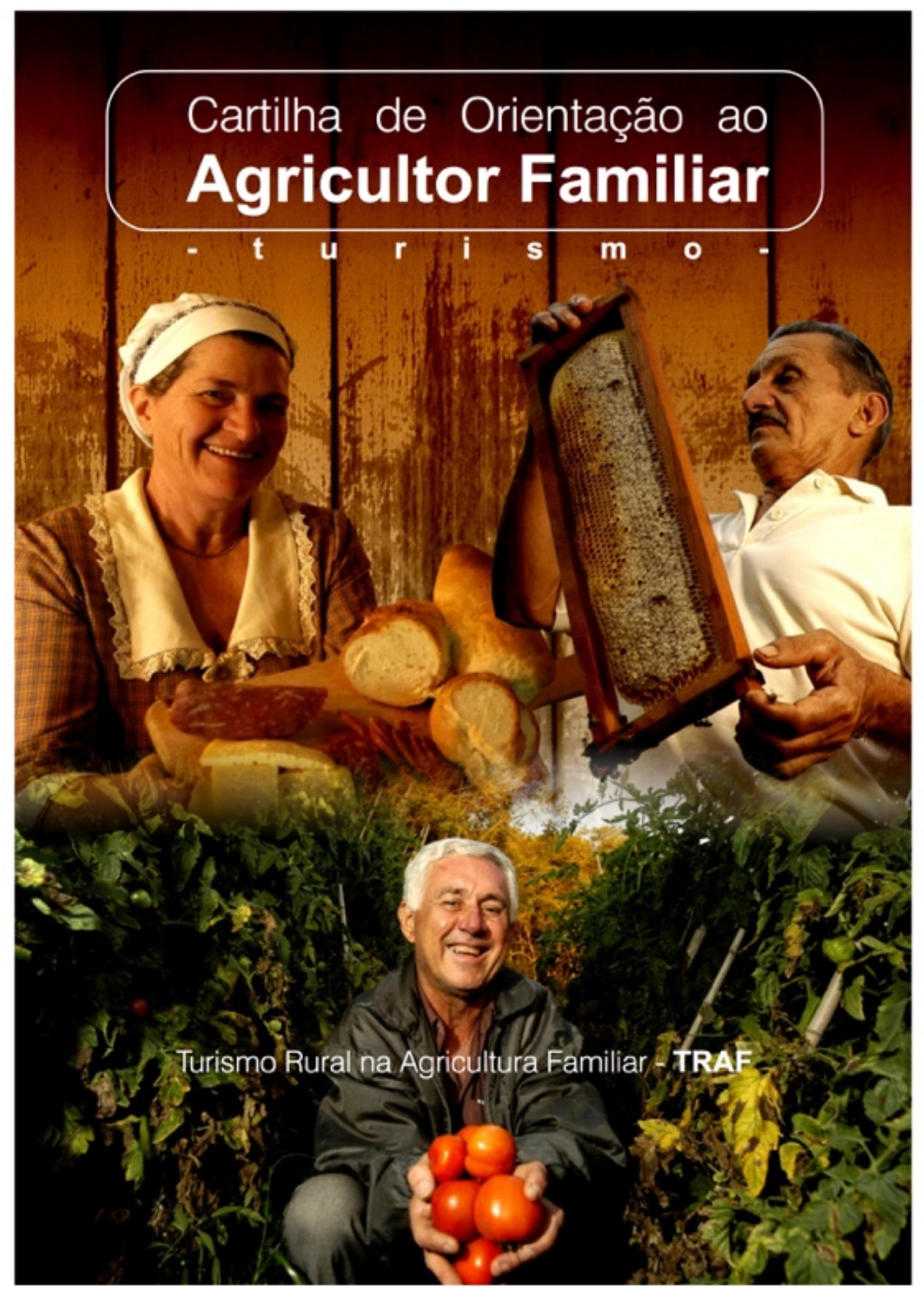

Figura 25. Reprodução da capa de Cartilha desenvolvida no Paraná. 




Figura 26. Reprodução da capa de Cartilha desenvolvida no Ceará.

O incentivo ao turismo rural também entra no leque de ações desenvolvidas pelo MDA.

Em 2003, o ministério lançou o Programa de Turismo Rural para a Agricultura Familiar.

O que pretendem o Ministério do Desenvolvimento Agrário, o Ministério do Turismo e parceiros é trabalhar de forma integrada, utilizando-se de toda atividade turística no meio rural como fator de mobilização nacional para proporcionar retorno financeiro e melhores condições de vida aos produtores, famílias e comunidades rurais.

O Turismo Rural na Agricultura Familiar vem ocorrendo em determinadas regiões e é produto das iniciativas promovidas pelos agricultores com apoio de entidades ligadas à Assistência Técnica e Extensão Rural e a entidades da sociedade civil, em organizações comunitárias, formais e informais, gerando novas formas de trabalhos e negócios diversificados (BRASIL, 2004, p. 8).

Com duração prevista apenas até 2007, o programa não foi continuado após seu término.

Entretanto, é possível perceber repercussões da Rede TRAF (Rede de Turismo Rural da Agricultura Familiar) em iniciativas desenvolvidas posteriormente nos estados. Além disso, outras ações de incentivo ao desenvolvimento do Turismo Rural entre produtores da Agricultura Familiar o seguiram, conforme anuncia o site do ministério, agora secretaria especial:

Desde 2003, o MDA/SAF vem apoiando a estruturação e o fortalecimento de roteiros turísticos que tenham como base a agricultura familiar. Tem trabalhado, ainda, no sentido de propiciar à produção familiar sua inserção no mercado turístico. 
Da mesma forma, o MDA tem estimulado o artesanato com base na perspectiva da produção associada nas regiões turísticas, seja por meio de projetos específicos ou pelo Programa Talentos do Brasil. [...]

Ações desenvolvidas

São apoiados projetos nas áreas de turismo e artesanato de forma individual ou coletiva.

Os projetos individuais, que contribuam para a implantação ou estruturação das atividades turística ou artesanal em propriedades rurais familiares, podem ser financiados pelo Pronaf.

Para os projetos coletivos, o MDA conta com a parceria do Ministério do Turismo e o auxílio da Rede Temática de Ater em Produtos e Mercados Diferenciados para realizar a estruturação de roteiros turísticos e a inserção da produção familiar no mercado turístico. ${ }^{67}$

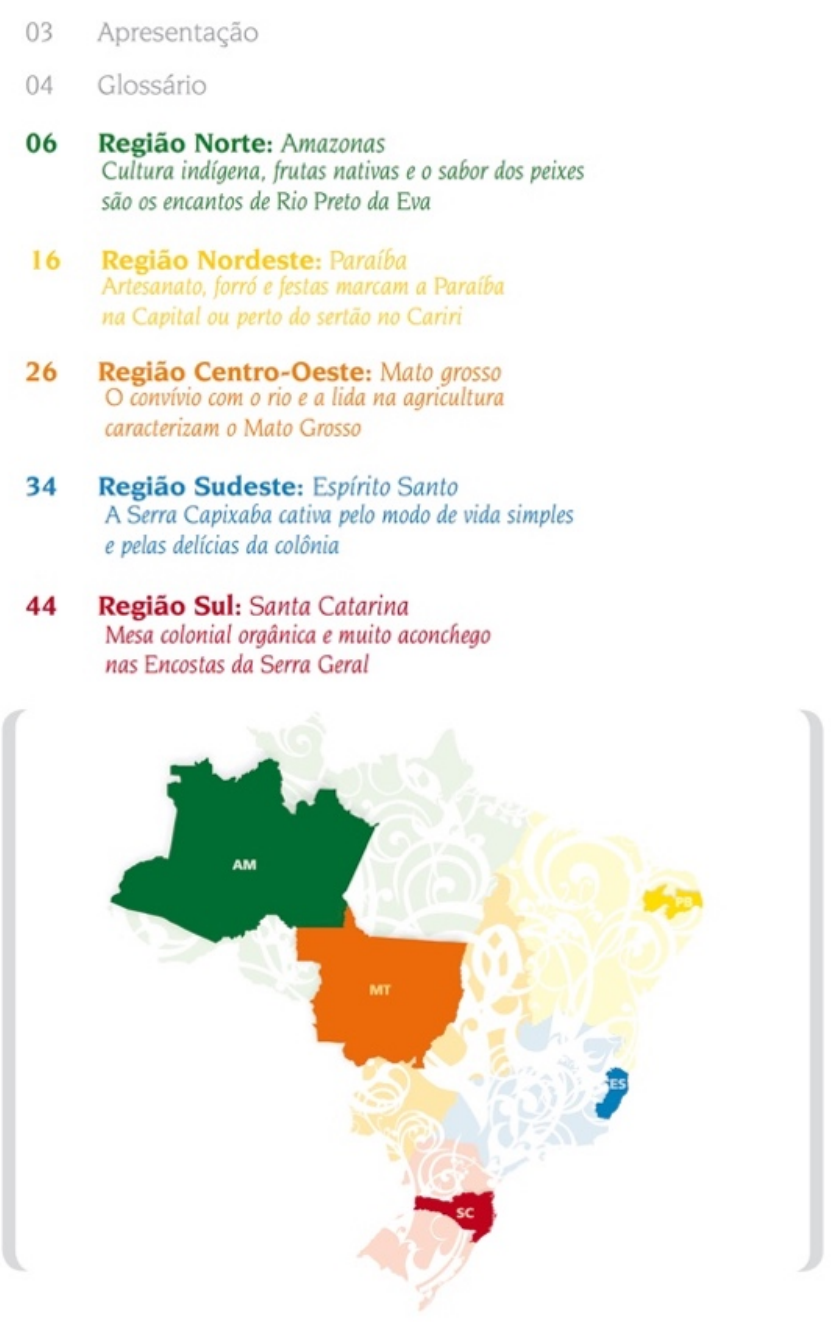

Figura 27. Reprodução da publicação 'Caminhos do Brasil Rural - agricultura familiar, turismo e produtos associados', fruto da parceria entre MTur e MDA. Junho de 2008.

${ }^{67}$ Disponível em http://www.mda.gov.br/sitemda/secretaria/saf-divecon/turismo-e-artesanato. Consultado em 28 out. 2016. 
cessidade nasceu a habilidade de lidar com a madeira e hoje o Seu Antônio faz móveis e entalhes belíssimos, sempre com a temática regional, com figuras de araras, tucanos e onças.

As madeiras - angelins, louros, murapitangas - são aproveitadas completamente. Com as toras, ele faz as peças maiores, como mesas e sofás, que incorporam as imperfeições da madeira caída naturalmente. Com os galhos faz bancos e estantes e com as raízes faz abajures e chafarizes. Até as folhas são aproveitadas em belos arranjos e as cascas viram cestas nas mãos de dona Ednelza, que também

\section{Café Regional Flora Eva}

O casal João Batista da Silva, 38 anos, e Leda Maria Souza dos Santos, 42 , recepcionam os turistas com uma maravilhosa mesa de quitutes amazonenses, servidos em um agradável quiosque junto à entrada do sítio. Eles aprenderam a atender bem em Manaus, onde ambos trabalhavam com turismo, ele como cozinheiro e ela como recepcionista de hotel.

Filha de agricultores, ela tinha alguma intimidade com a terra e ambos resol-

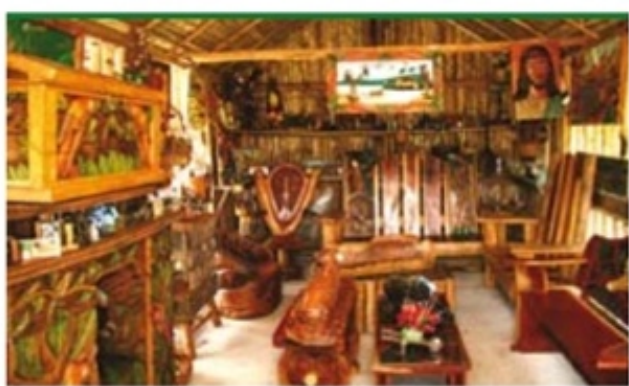

auxilia a lixar a madeira e a pintar os motivos. Ele atende a encomendas e tem exemplares disponíveis para venda direta.

veram experimentar a vida no campo, há 10 anos. No Sítio Nova Jerusalém, propriedade de 31 hectares, os dois viraram agricultores e hoje produzem, sem agrotóxicos, tudo o que servem. Ele foi redescobrindo antigos segredos da terra como aplicar adubação natural de esterco de galinha, ou fazer um preparado de acerola, carambola e outras frutas ácidas, fermentadas por cerca de 15 dias, para substituir a uréia na adubação; ou ainda macerar cravo da índia para inseticida.

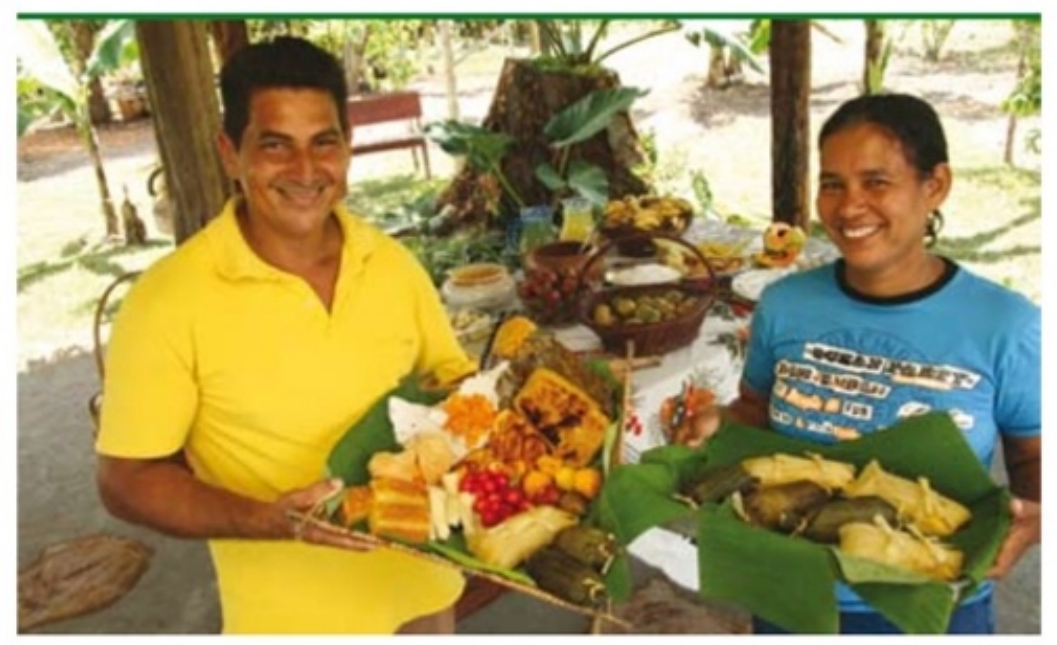

Figura 28. Reprodução da publicação 'Caminhos do Brasil Rural - agricultura familiar, turismo e produtos associados', fruto da parceria entre MTur e MDA. Junho de $2008 .^{68}$ 
A Rede Temática de Ater (Assistência Técnica e Extensão Rural), é um outro exemplo de iniciativa com potencial de crescimento, mas que não teve continuidade. Em estudo que acompanhou a participação e interação na Rede, Bock e Tomazzoni (2013) observaram que a ferramenta serviu muito pouco para a integração, de 2010 a 2012. O que justifica a dificuldade que tivemos em nossa pesquisa de encontrar informações sobre esse projeto após essa data - e a impossibilidade de se conectar na rede atualmente - mesmo que muitas das informações continuem disponíveis.

A estrutura formal está disponível, mas ninguém a estimula. Foi lançada envolvendo dois ministérios, mas os próprios participantes desses órgãos não colaboram e não propõem discussões. A rede não se mostra atrativa e ainda não se pode observar um grau de conscientização e de cooperação suficientemente forte entre os participantes para que seja ela mantida. Devese aqui salientar que a maioria dos membros pertence ao setor público envolvido diretamente com as temáticas "turismo", "rural" e "desenvolvimento regional" (BOCK; TOMAZZONI, 2013, p. 131).

Por fim, ainda permanece, conforme descrito no site do MDA, a possibilidade de financiamento de projetos individuais ou coletivos de turismo rural da agricultura familiar através do Programa Nacional de Fortalecimento da Agricultura Familiar, o PRONAF. A Linha de Crédito de Investimento para Agregação de Renda à Atividade Rural - PRONAF Agroindústria prevê financiamento para:

\subsubsection{Finalidades}

Investimentos, inclusive em infra-estrutura, que visem o beneficiamento, à armazenagem, processamento e comercialização da produção agropecuária, de produtos florestais e do extrativismo, ou de produtos artesanais, e a exploração de turismo rural, incluindo-se:

a) A implantação de pequenas e médias agroindústrias, isoladas ou em forma de rede;

b) A implantação de unidades centrais de apoio gerencial, nos casos de projetos de agroindústrias em rede, para a prestação de serviços de controle de qualidade do processamento, de marketing, de aquisição, de distribuição e de comercialização da produção;

c) A ampliação, recuperação, ou modernização de unidades agroindustriais de agricultores familiares já instaladas e em funcionamento, inclusive de armazenagem;

d) Aquisição de equipamentos e de programas de informática voltados para melhoria da gestão das unidades agroindustriais, mediante indicação em projeto técnico;

e) O capital de giro associado limitado a $35 \%$ (trinta e cinco por cento) do financiamento para investimento fixo;

f) A integralização de cotas-parte vinculadas ao projeto a ser financiado; Admite-se que no plano ou projeto de investimento individual haja previsão de uso de parte dos recursos do financiamento para empreendimentos de uso coletivo. (BRASIL, 2015d) 
Percebe-se assim que, além da relação estreita com o desenvolvimento do Slow Food no Brasil, o MDA tem desenvolvido nos últimos anos diversos programas e ações com o intuito de fortalecer o turismo rural no país. Nota-se um grande potencial em muitos desses projetos, mas, também, que muitos deles são descontinuados, impedindo um desenvolvimento consistente do segmento.

Nesse ensejo, uma iniciativa que pudemos observar de perto pode servir de exemplo. Guilherme Ferreira é de família de tradição de produção queijeira na Canastra. Seu pai, no entanto, não seguiu o ofício dos pais e mudou-se para o interior de São Paulo. Há alguns anos, após formar-se em veterinária, Guilherme resolveu retomar a produção artesanal de queijo Minas da Canastra. Com condições financeiras e conhecimento técnico - além das orientações de profissionais do SEBRAE e Emater - adequou a queijaria de Estância Capim Canastra à legislação sanitária, desenvolveu rótulos e uma identidade visual e associou-se à APROCAN responsável pela IP do queijo da Canastra. Começou também um trabalho de recuperação do gado caracu, que era tradicionalmente utilizado na produção leite na região, mas atualmente é raro.

Em 2015, seu queijo foi levado para Tours, na França, sem que soubesse, e inscrito em uma competição mundial. Foi premiado com a medalha de prata entre os queijos de massa dura. $\mathrm{O}$ reconhecimento internacional transformou-se rapidamente em fama nacional. O produto ganhou em valor de mercado e, ao optar por não aumentar a produção de 20 a 30 peças diárias, tornou-o concorrido. Até aqui, poderia ser apenas mais um caso de sucesso econômico, devido a uma conjunção de fatores que favorecessem tal destaque. As críticas ao produtor apareceram e uma delas, que apresentamos anteriormente, é a de que ele foi um dos que iniciaram a busca por um padrão afrancesado, por assim dizer, ao mofar os queijos.

O que nos interessa aqui é sequência de produtos associados ao queijo que Guilherme passou a desenvolver, ao perceber o crescimento da demanda. A Estância Capim Canastra fica em São Roque de Minas, região bastante procurada para o ecoturismo, devido às nascentes e quedas d'água que são abundantes na área. Ao visitar o local, é comum que os turistas, parem em fazendas à beira da estrada para comprar queijo artesanal de minas diretamente dos produtores. Com o aumento da demanda, Guilherme passou então, a oferecer não apenas o produto, mas, em datas pré-estabelecidas, vivência do processo de produção do queijo. Agregou a isso a possibilidade de pacotes para um fim de semana turístico na fazenda: a hospedagem é na casa em que fica com a esposa e o filho; as refeições são inclusas e contam com porco assado na brasa, churrasco, pão de queijo e, claro, muito queijo. 
Além de levar os turistas para conhecer as belezas naturais da região, Guilherme organiza um jantar de degustação de queijos da Canastra, onde convida vários produtores para uma noite de confraternização. Após produzir o próprio queijo, o turista pode levá-lo para casa para maturá-lo. A Capim Canastra comercializa ainda, pequenos maturadores de madeira, com espaço para dois queijos. Para finalizar, Guilherme ainda acompanha os turistas em visita a outras fazendas produtoras para que possam comprar: queijo. É possível perceber uma dinâmica de valorização coletiva e uma consciência entre os produtores de que, quanto mais eles forem, mais turistas e consumidores terão.

Ou seja, há potencial para ser desenvolvido e as ações precisam focar no empoderamento do pequeno produtor da agricultura familiar: para que eles possam outros como o Guilherme possam ter no turismo rural uma ferramenta a mais de crescimento. No entanto, para que se alcance tais resultados, é preciso políticas públicas contínuas.

\title{
Ministério do Turismo
}

Não há, no Brasil, uma política pública focada no incentivo do turismo gastronômico per se. A cultura alimentar nacional, explica a Coordenação Geral de Turismo Responsável (CGTR), é abordada pelo MTur como um dos elementos da atividade turística.

\begin{abstract}
A gastronomia é um dos elementos chave da Produção Associada ao Turismo. Preservar a cultura e os pratos típicos de uma região é uma forma de torná-la única, além de uma boa oportunidade para alavancar o turismo e contribuir para o seu desenvolvimento sustentável. Por este motivo, é um dos elementos contemplados dentro da ação de apoio ao Turismo Responsável.

Encontra-se em vigência atualmente um Acordo de Cooperação entre o Ministério do Turismo, o Ministério da Agricultura, Pecuária e Abastecimento - MAPA e o Ministério do Esporte - ME, que tem como objetivo geral a implementação de ações conjuntas para identificar, ordenar, promover e fortalecer a relação entre as atividades de pesca e aquicultura e o turismo no Brasil. Uma destas ações é a promoção da gastronomia com base em pratos típicos de todas as regiões do país, que possuam como ingrediente principal produtos pesqueiros e aquícolas. O projeto encontra-se em fase de coleta de dados com os estados.

A valorização da gastronomia local também é um dos temas abordados no Guia Turismo e Sustentabilidade - publicação do MTur de 2016 que traz orientações e dicas práticas de sustentabilidade voltadas aos prestadores de serviços turísticos ${ }^{69}$.
\end{abstract}

Nessa perspectiva, analisaremos aqui como as políticas desenvolvidas pelo ministério constroem o discurso e a relação com a gastronomia. Para iniciar, o Plano Nacional de Turismo 2013-2016. O primeiro ponto que emerge é a crítica, que debatemos no segundo capítulo, de que as políticas públicas do turismo priorizam seu aspecto econômico em relação ao de

\footnotetext{
${ }^{69}$ Resposta concedida em 05/09/2016, à demanda feita através do programa de acesso à informação.
} 
fenômeno social. Isso se evidencia mesmo quando o discurso é de busca da construção de um turismo sustentável.

A formulação e o planejamento de políticas públicas devem ter como pressuposto a obtenção de resultados efetivos que se estendam a toda a sociedade. Em um país com a dimensão e a complexidade do Brasil, o turismo constitui uma atividade econômica com grande potencial de alavancar e contribuir para a consolidação do desenvolvimento socioeconômico equilibrado, mesmo em distintas condições territoriais.

O potencial de desenvolvimento turístico oferece ao mesmo tempo oportunidade e desafio para a execução de ações de proteção ao meio ambiente e de promoção do seu uso economicamente sustentável, com respeito aos costumes regionais, viabilizando grandes avanços na inclusão social e na distribuição da riqueza.

É nesse contexto que o Plano Nacional de Turismo 2013-2016 se insere como referência para a política pública setorial do turismo, que deve ter como perspectiva a efetivação do potencial da atividade para um desenvolvimento econômico sustentável, ambientalmente equilibrado e socialmente inclusivo (BRASIL, 2013, p. 52, grifo nosso).

\begin{tabular}{|c|c|c|c|c|c|c|c|}
\hline \multicolumn{8}{|c|}{ MARCO LÓGICO - AGENDA ESTRATÉGICAPNT EM AÇÃO } \\
\hline \multicolumn{5}{|c|}{$\begin{array}{l}\text { AMBIENTE ECONOMICO INTERNACIONAL - 2013/2022 } \\
\text { TRAJETORIAS: PIB - EMPREGO - RENDA }\end{array}$} & \multicolumn{3}{|c|}{$\begin{array}{l}\text { AMBIENTE ECONÔMICO NACIONAL - 2013/2022 } \\
\text { TRAJETÓRIAS: PIB - CÂMBIO - JUROS - EMPREGO - RENDA }\end{array}$} \\
\hline \multicolumn{5}{|c|}{$\begin{array}{l}\text { TURISMO INTERNACIONAL - 2013/2022 } \\
\text { TRAJETORIAS: PIB - FLUXO - RENDA }\end{array}$} & \multicolumn{3}{|c|}{$\begin{array}{l}\text { TURISMO NACIONAL - 2013/2022 } \\
\text { TRAJETORIAS: PIB - FLUXO - RENDA }\end{array}$} \\
\hline \multicolumn{8}{|c|}{ METAS GERAIS PARA O TURISMO NACIONAL: 2014 - 2018 - 2022} \\
\hline \multicolumn{8}{|c|}{$\begin{array}{l}\text { PREMISSA: PROMOÇÃO DO DESENVOLVIMENTO ECONOMMICO EQUILIBRADO, SOCIALMENTE JUSTO, } \\
\text { CULTURALMENTE DINÂMICO E ECOLOGICAMENTE RESPONSÁVEL }\end{array}$} \\
\hline \multicolumn{8}{|c|}{$\begin{array}{l}\text { PROCESSO DE GESTÃO: GESTÃO DESCENTRALIZADA E COMPARTILHADA - GESTÃO DO CONHECIMENTO, DA INOVAÇÃO, } \\
\text { DA TECNOLOGIA, DA CRIATIVIDADE E DA COMPETITIVIDADE }\end{array}$} \\
\hline \multicolumn{4}{|c|}{$\begin{array}{l}\text { ABORDAGEM TEMÁTICA: MACROAMBIENTES } \\
\text { DE NEGOCIO }\end{array}$} & \multicolumn{4}{|c|}{ ABORDAGEM TRANSVERSAL: CADEIA PRODUTIVA DO TURISMO } \\
\hline \multirow{2}{*}{$\begin{array}{l}\text { PARQUES } \\
\text { NATURAIS }\end{array}$} & \multirow{2}{*}{ LITORAL } & \multirow{2}{*}{$\begin{array}{l}\text { TURISMO } \\
\text { CULTURAL }\end{array}$} & \multirow{2}{*}{$\begin{array}{c}\text { "N" } \\
\text { OUTROS }\end{array}$} & LEGISLAÇÃO & $\begin{array}{l}\text { INFRAESTRUTURA } \\
\text { CAT - SINAL - INVEST }\end{array}$ & ACESSIBILIDADE & REGIONALIZAÇÃO \\
\hline & & & & CRÉDITO & QUALIFICAÇÃO & GESTÃO & $\begin{array}{l}\text { PROMOÇÃOE E } \\
\text { COMERCIALIZAÇÃO }\end{array}$ \\
\hline \multicolumn{8}{|c|}{ GARGALOS, SOLUÇÕES E OPORTUNIDADES } \\
\hline \multicolumn{8}{|c|}{$\begin{array}{l}\text { METAS DE DESEMPENHO POR TEMA: } 2014 \text { - } 2018 \text { - } 2022 \\
\text { POLIITICAS PÚBLICAS: LEGISLAÇÃO, PROGRAMAS, PROJETOS E AÇÕES PARA VIABILIZAÇÃO DAS METAS } \\
\text { IMPACTOS: GERAIS - TEMÁTICO - DAS POLÍTICAS - DOS PROGRAMAS - DAS AÇÕES }\end{array}$} \\
\hline \multicolumn{3}{|c|}{$\begin{array}{l}\text { ECONôMICOS } \\
\text { Incremento na competitividade, aumento } \\
\text { de receitas das atividades do turismo, } \\
\text { maior volume de arrecadação de impostos, } \\
\text { crescimento do PIB, efeitos sinérgicos etc. }\end{array}$} & \multicolumn{2}{|c|}{$\begin{array}{l}\text { AMBIENTAIS } \\
\text { Crescimento ordenado, preservação } \\
\text { do patrimônio natural, qualidade das } \\
\text { cidades, combate à especulação } \\
\text { imobiliária e à favelizaçãa etc. }\end{array}$} & \multicolumn{3}{|c|}{$\begin{array}{l}\text { SOCIAIS } \\
\text { Geração de empregos, elevação do nível } \\
\text { cultural da população, desconcentração do } \\
\text { desenvolvimento etc. }\end{array}$} \\
\hline
\end{tabular}

Tabela 2. Marco Lógico - Agenda Estratégica e PNT em Ação (BRASIL, 2013, p. 107).

Ainda focando nessa faceta do turismo, documento apresenta o objetivo de posicionar o Brasil entre as três maiores economias turísticas do mundo até 2022, sendo que, em 2011, o 
país ocupava a $6^{\text {a }}$ colocação na lista do World Travel \& Tourism Council (WTTC). Para isso, apresenta quatro grandes metas para o período de 2013 a 2016: “(I) preparar o turismo brasileiro para os megaeventos; (II) incrementar a geração de divisas e a chegada de turistas estrangeiros; (III) incentivar o brasileiro a viajar pelo Brasil; e (IV) melhorar a qualidade e aumentar a competitividade do turismo brasileiro" (BRASIL, 2013, p. 64).

Chama a atenção, no tocante ao tema deste trabalho, que, mesmo ao propor uma abordagem temática do Turismo como uma das opções, o PNT não menciona a gastronomia como um dos recortes possíveis e muito menos trata dos inventários do patrimônio alimentar nacional como potenciais atrativos turísticos:

A abordagem temática considera grandes temas como parques nacionais,
turismo de litoral, turismo cultural, turismo de saúde, turismo esportivo,
parques temáticos, entre outros, como macroambientes de negócios.
Para uma atuação focada nos macroambientes de negócio, a premissa susten-
ta-se na compreensão de que é neles que as oportunidades se concretizam.
É também aí que os interesses da cadeia do turismo podem ser conciliados e
potencializados em função dos objetivos comuns.
Tal abordagem permite identificar, de forma integrada, as forças e as fraque-
zas presentes, ficando evidente a necessidade da ação governamental e, assim,
medidas de políticas públicas podem ser editadas e implementadas de forma
mais assertiva e consistente. (BRASIL, 2013, pp. 105-106)

Outro ponto da política desenvolvida pelo MTur que é fundamental para o debate que aqui propomos é a de Regionalização do Turismo, que se iniciou em 2003, como parte de um processo de descentralização do planejamento. Conforme debatemos no segundo capítulo, um dos motivadores do crescimento do Turismo Gastronômico em países como França e Itália foi exatamente o movimento de regionalização. No entanto, no programa do MTur, a cultura alimentar apresenta-se apenas como mais um item do produto turístico. Com isso, ao contrário do que ocorreu naqueles países, os inventários do patrimônio alimentar nacional desenvolvidos pelo IPHAN, INPI e Slow Food são ignorados - e seu potencial como produto turístico inexplorado. Como consequência, a abordagem corre o risco de cair na simplificação do "prato típico regional”, apontada por Carlos Alberto Dória (2014) como característica dos guias turísticos brasileiros.

Um exemplo é a matéria “10 pratos para saborear o Brasil”, publicada em julho de 2016 no site do ministério:

Uma dose indígena e uma africana, uma pitada europeia e um punhado de latinidade misturados em um país continental como o Brasil só poderia ter um resultado: uma gastronomia variada e riquíssima em sabor. Quem não experimentou e se apaixonou pelos peixes de rio da Amazônia? Ou pelos camarões do Nordeste? Sem citar o fondue no friozinho do Sul... 
Selecionamos 10 pratos que devem ser provados nas viagens pelo Brasil. Não comer significa não ter a experiência por completo! $!^{70}$

As dicas são de preparos e cidades onde degustá-los: café colonial em Canela (RS); Comidas típicas das festas de São João no Maior São João do Mundo, em Campina Grande (PB); Carne de Sol na Paraíba; o camarão nordestino em Porto de Galinhas (PE); o fondue em Gramado (RS); os peixes amazônicos em Manaus; a comida mineira em Tiradentes; o empadão goiano em Cidade de Goiás; a dormência em Santarém e Alter do Chão (PA); e o açaí em Belém (PA). Esse tipo de redução de uma região a um prato ou ingrediente, no entanto, acaba por colaborar com um modelo de turismo que não representa toda a complexidade cultural de uma região. Retomamos, assim, a discussão do primeiro capítulo, com o conceito de Bhabha (2003) de formação de uma memória nacional como uma imposição de cima para baixo. Essa simplificação de pratos típicos não é capaz de compreender toda a teia de significados que compõem as tradições gastronômicas do país. Ela também não possibilita levar em conta as singularidades de sua formação em cada localidade do país, dentro de cada grupo identitário e termina apenas seguindo as divisões políticas nacionais.

No site do MTur também é possível encontrar inúmeras notícias focando na gastronomia de cidades ou regiões. Os festivais gastronômicos e a participação do Brasil em feiras, com stands dedicados à reprodução de "pratos típicos brasileiros" também são tópicos recorrentes de reportagens. Na série "Pelo Brasil" e durante o revezamento da tocha olímpica, a culinária também merece menção.

Em matéria publicada em 28 de julho de 2014, logo após a Copa do Mundo da FIFA, o destaque foi para a aceitação da gastronomia brasileira por parte dos estrangeiros.

A culinária vem ganhando importância no turismo brasileiro. Dados da
Confederação Nacional de Turismo registram, por ano, 10 grandes encontros
que reúnem chefs brasileiros e estrangeiros e restaurantes tradicionais no país.
Além disso, os festivais regionais já ultrapassam 10 mil edições.
Pesquisa de demanda turística internacional, realizada pelo MTur (2012),
aponta a gastronomia como um dos itens com maior aprovação entre os
visitantes estrangeiros: cerca de $90 \%$ de satisfação. Isso prova que o turismo
gastronômico está presente tanto nas opções de lazer quanto para os
negócios.

Em outra ação voltada para o nosso escopo de estudo, o MTur publicou em 2015 uma chamada pública de Valorização da Gastronomia Regional como fator diferencial de Competitividade do Destino Turístico. Poderiam concorrer projetos destinados a um dos 214

\footnotetext{
${ }^{70}$ Disponível em http://www.turismo.gov.br/\%C3\%BAltimas-not\%C3\%ADcias/6521-10-pratos-para-saborear-obrasil.html. Consultado em 30 out. 2016.

${ }^{71}$ Disponível em http://www.turismo.gov.br/\%C3\%BAltimas-not\%C3\%ADcias/1866-gastronomia-brasileira-ebem-avaliada-por-estrangeiros.html. Consultado em 29 out. 2016.
} 
munícipios inseridos no Mapa do Turismo Brasileiro, que apresentassem propostas, para serem executadas no prazo de um ano, com custo de até $\mathrm{R} \$ 300.000,00$. Dez delas foram, como previsto, selecionadas - mesmo que a preferência pelo equilíbrio de dois projetos por região não tenha sido alcançada. Araranguá (SC), Belo Horizonte (MG), Corumbá (MS), Diamantina (MG), Foz do Iguaçu (PR), Gramado (RS), Natal (RN), Paranaguá (PR), Rio Branco (AC) e Vitória (ES) foram contempladas.

Mais uma vez, se observa a ausência de menção aos inventários do patrimônio alimentar nacional. Certificações como do IPHAN, do INPI e do Slow Food, podem ser uma forma de aliar, retomando a ideia de Scarpato (2002), uma gastronomia sustentável com um turismo sustentável. No entanto, um projeto intitulado Valorização da Gastronomia Regional ignora a existência de ferramentas de registro de um patrimônio cultural ameaçado, desenvolvidas por instituições ligadas ao Governo Federal. A busca pela valorização do local, conforme discutido no capítulo dois, tem sido o ponto de encontro entre turismo e gastronomia em diversos países do mundo. Ainda assim, nota-se uma abordagem pouco focada do MTur nesse sentido.

Nessa chamada pública, as propostas selecionadas eram variadas, de promoção de Festivais gastronômicos, a encontros educativos, passando por produção de livro de receitas da cultura alimentar local e até mesmo pesquisa de Inventário de Referência Cultural para subsidiar pedido de registro no IPHAN do Ofício das Desfiadeiras de Siri. No entanto, com o corte do orçamento sofrido pelo ministério em fevereiro de 2016, todos os 10 convênios foram encerrados ${ }^{72}$.

O Mapa do Turismo Brasileiro, aliás, é uma das ações da Política de Regionalização do MTur. Ele funciona com instrumento de orientação para o desenvolvimento de políticas públicas pelo ministério. O objetivo é, através de uma construção em conjunto com as autoridades regionais e locais, planejar a gestão, estruturação e promoção do turismo. Atualmente ele conta, em todo o país, com 2.175 municípios identificados em 291 regiões turísticas. Em 2016 o mapa foi atualizado e redimensionado, com uma diminuição do número de municípios cadastrados (que passavam de três mil). $\mathrm{O}$ objetivo, de acordo com o ministro interino à época, Alberto Alves, era possibilitar um trabalho de coordenação mais próxima entre o ministério, os estados, as regiões turísticas e os municípios ${ }^{73}$.

\footnotetext{
${ }^{72}$ Diz o Ofício nº69/2016/SNPTur/MTur, de 06 de setembro de 2016: “a limitação orçamentária e financeira estabelecida ao Ministério do Turismo pelo Decreto $n^{\circ} 8.670$, de 12 de fevereiro de 2016, e alterações posteriores, tornou inviável a consecução do objeto conveniado".

${ }^{73}$ Disponível em http://www.turismo.gov.br/\%C3\%BAltimas-not\%C3\%ADcias/6463-alagoas-tem-novo-mapatur\%C3\%ADstico.html. Consultado em 19 out. 2016.
} 
Além dele, vale destacar aqui o Inventário da Oferta Turística, InvTur. Lançado em 2006, o projeto já passou por revisões em 2008 e 2010, até chegar no formato atual, proposto em 2011. Ele tem por objetivo levantar dados confiáveis do potencial turístico dos municípios através de uma metodologia-padrão, a fim de subsidiar desde planejadores, gestores até futuros visitantes (BRASIL, 2011) ${ }^{74}$. A justificativa para tal inventário vai de encontro ao que temos debatido neste trabalho: a cultura não é universal, mas particularizada. Uma vez que ela é socialmente construída, terá suas variações de acordo com a época e com o território nos quais se insere.

O passo inicial para tal pretensão é a realização do Inventário da Oferta Turística, para o qual se toma o caminho do município como unidade de referência, por duas razões principais. A primeira deve-se ao fato de que é no território, de modo geral sob a jurisdição municipal, que se materializam o patrimônio natural e o cultural, com destaque para a nossa maior riqueza - a nossa gente, seus saberes e fazeres. A segunda razão é que o Ministério do Turismo está empenhado em trabalhar o turismo de forma regionalizada, considerando o conjunto de peculiaridades de cada território, pelo simples fato de que, na maioria das vezes, a atividade turística não se viabiliza apenas no âmbito de um município. Dessa forma, um destino turístico deve ser trabalhado de maneira integrada, englobando municípios. Tal iniciativa possibilita diversificação da oferta e constituição de roteiros, estruturados com base na identidade e na coesão social, cultural e territorial de cada lugar, mas indubitavelmente com o domínio intuitivo do seu significado. (BRASIL, 2011, p. 17)

Nessa perspectiva, a estrutura dos formulários de pesquisa dos inventários nos permite analisar como a gastronomia pode estar presente nas três categorias apresentadas: Infraestrutura de apoio ao turismo; Serviços e equipamentos turísticos; e Atrativos turísticos (BRASIL, 2011). $\mathrm{Na}$ primeira, no item de Compras especiais, figuram feiras e mercados, cantinas, caves, bodegas, alambiques e outras possibilidades. Na parte de serviços, os equipamentos de alimentos e bebidas. Por fim, entre os atrativos turísticos, a gama de alternativas é extensa: entre os atrativos culturais, as comunidades tradicionais, os itinerários culturais, os lugares de referência à memória, a arquitetura industrial/agrícola, as atividades tradicionais de trabalho, todos podem ser abordados a partir da perspectiva da cultura alimentar, além de, claro, a gastronomia típica e preparação de alimentos. Há ainda, entre os atrativos turísticos, as atividades econômicas (agricultura, pecuária, aquicultura, etc.) e os eventos programados, como feiras, exposições, festivais, festas e celebrações, com potencial para o desenvolvimento de um turismo gastronômico.

\footnotetext{
${ }^{74}$ Apesar da possibilidade declarada de visitantes poderem ter acesso ao relatório, quando consultado, em 28 out. 2016, o site http://www.inventario.turismo.gov.br/invtur/ não dava acesso a quem não tivesse login e senha. Dessa forma, as únicas informações abertas eram a situação dos inventários por município (se em processo ou encerrado) e os responsáveis por sua elaboração.
} 
Por fim, retomamos o debate do discurso de sustentabilidade como ponto de encontro entre turismo e gastronomia ao analisar o Guia Turismo e Sustentabilidade (BRASIL, 2016), citado pela Coordenação Geral de Turismo Responsável no início dessa discussão. O guia utiliza-se da definição de "Sustentabilidade" apresentada no Relatório Brundtland, aqui já discutido: "Sustentabilidade significa 'atender às necessidades do presente sem comprometer a capacidade de as gerações futuras atenderem também às suas"” (BRASIL, 2016, p. 7). Nessa perspectiva, reafirma o conceito de Turismo Sustentável como já definido no Programa de Regionalização do Turismo: “Turismo sustentável é a atividade que satisfaz as necessidades dos visitantes e as necessidades socioeconômicas das regiões receptoras, enquanto os aspectos culturais, a integridade dos ambientes naturais e a diversidade biológica são mantidas para o futuro" (BRASIL, 2016, p. 7).

Ao apresentar o guia, entretanto, define-se que o objetivo é disseminar o conhecimento e práticas de sustentabilidade, "gerando retorno positivo em um ou mais dos aspectos: econômico, social e ambiental" (BRASIL, 2016, p.6). Ou seja, não se apresenta a sustentabilidade como uma harmonia necessária entre os três campos. O documento ainda traz um novo conceito para o debate. Além da Sustentabilidade Ambiental, Sociocultural e Econômica, o MTur inclui entre os seus princípios a Sustentabilidade Político-Institucional, ponto que debateremos mais a fundo à frente, cuja importância é destacada pois "Assegura a solidez e continuidade das parcerias e compromissos estabelecidos entre os diversos agentes e agências governamentais dos três níveis de governo e nas três esferas de poder, além dos atores situados no âmbito da sociedade civil” (BRASIL, 2016, p. 8).

O texto aponta, ainda, sob forma de recomendação, a crítica às contradições que o uso do termo sustentável sofre.

\footnotetext{
Vale a pena ressaltar que as ações de sustentabilidade aplicadas nos empreendimentos não devem ser apenas atitudes superficiais que visem sua promoção aproveitando o chamado "Marketing Verde". As práticas adotadas devem apresentar resultados concretos e significativos para o meio ambiente e a sociedade. (BRASIL, 2016, p. 9)
}

A gastronomia surge no documento em dois momentos. Primeiro, entre as dicas práticas em sustentabilidade sociocultural: "Valorize a gastronomia, ofereça em seu empreendimento pratos típicos da região e iguarias feitas por produtores locais" (BRASIL, 2016, p. 17). O segundo é entre as possibilidades de engajamento: serviços de alimentação podem aderir à campanha Passaporte Verde, ou podem buscar certificações em sustentabilidade - no caso, é apontada a NBR 15635:2015, que é uma norma que especifica requisitos de boas práticas e de controles operacionais para estabelecimentos que desejam comprovar e documentar que 
produzem alimentos em condições higiênico-sanitárias adequadas para o consumo (BRASIL, 2016).

Percebe-se, assim, o que havíamos afirmado no início desta análise: a gastronomia não é trabalhada pelo Ministério do Turismo como um ponto de destaque do fenômeno turístico. $\mathrm{O}$ que se nota, é que há diversas políticas e projetos que a abarcam tangencialmente. E, até mesmo, um discurso de comunicação que coloca a cultura alimentar como um dos atrativos turísticos do Brasil, mesmo que, muitas vezes, de forma simplista. É interessante ainda notar, a ausência de menções aos três inventários do patrimônio alimentar brasileiro aqui analisados nos projetos e ações. A única citação encontrada foi em um dos projetos da chamada pública que foi cancelada. Não há, portanto, por parte do MTur, uma interação ou uso desses patrimônios como atrativos turísticos.

Ao encerrar a análise das políticas, projetos e ações desenvolvidos pelos três ministérios, chama a atenção a integração apenas pontual entre eles. Raramente as políticas são desenvolvidas em conjunto, como no caso da parceria entre MDA e MTur e o 'Caminhos do Brasil Rural - agricultura familiar, turismo e produtos associados'. É possível notar, ainda, uma falta de continuidade em algumas ações, ou, retomando o conceito apresentado pelo guia do MTur, uma falta de Sustentabilidade Político-Institucional. Iniciativas com potencial de desenvolvimento são lançadas, iniciadas e, por fatores diversos, interrompidas ou abandonadas. As políticas nacionais, do MinC e do MTur apresentam-se, nessa perspectiva, como uma tentativa de construção de projetos a longo prazo, em uma direção definida. Nesse sentido, o MDA apresenta-se na situação mais complexa, uma vez que, ao ser reduzido a secretaria especial, tem seu poder de ação também comprometido.

Essa mudança de status do MDA talvez seja uma das explicações para o grande número de documentos não mais disponíveis no site do órgão. Se a dificuldade de acessibilidade é, muitas vezes, um dos pontos em comum entre os três ministérios, por falta de clareza ou ausência de informações, no caso do MDA mostrou-se muito mais complicado encontrar informações - muitas vezes o site dá erro e diz que a página procurada não existe mais. Retomando o conceito de Cellard (2012), nos perguntamos por que esses documentos chegaram - ou não chegam mais - até nós.

Diante de todos esses fatores, retomamos as nossas perguntas iniciais: há atualmente no Brasil uma política pública de incentivo ao turismo gastronômico? Há alguma relação entre os diferentes inventários do patrimônio alimentar nacional e o fomento do turismo no país? A nossa hipótese se confirma ao percebermos que as instituições responsáveis pelos inventários patrimônio alimentar brasileiro, por terem objetivos diferentes, pouco se comunicam, e, muitas 
das vezes que o fazem é de forma conflituosa. O mesmo se nota entre os órgãos formuladores de políticas públicas. Percebe-se, dessa forma, que as ações de promoção do turismo gastronômico ainda não levam em conta esses inventários.

O que nos sugere uma nova questão: são os inventários do patrimônio alimentar brasileiro uma possibilidade para o incremento do turismo gastronômico? 


\section{CONSIDERAÇÕES FINAIS}

É preciso retomar o trajeto que traçamos até aqui, para que possamos desenvolver nossas últimas reflexões. A culinária é parte importante da cultura, memória e identidade de uma população. Em tempos marcados pela extrema fragmentação da identidade e pela aceleração do tempo, definido por Hall (2006) como modernidade tardia, o movimento referenciado nas tradições ganha força no processo de construção de uma identidade cultural. Nesse contexto, preparos, sabores e aromas surgem como lugares de memórias de grupos diversos.

Ao mesmo tempo, percebe-se que no Brasil do fim do século XIX a modernização foi bastante valorada - ao passo em que o antigo foi depreciado - o que pode ser notado já com o lema da bandeira nacional "ordem e progresso". Isso pode ter corroborado para que a ideologia de uma modernização necessária, em oposição ao antigo, à tradição, ganhasse força em alguns aspectos da vida social - entre eles, a gastronomia. Nessa perspectiva, é possível observar que a gastronomia popular tradicional, de origem indígena, negra e pobre foi, durante séculos, desvalorizada em relação à "civilizada e chic" culinária francesa. Ainda surgem como consequências do processo de modernização do país a delimitação do tempo de lazer, a inserção da mulher no mundo do trabalho, o processo de urbanização e a aceleração do ritmo de vida, que influenciaram as tradições culinárias nacionais, ao passo que refeições rápidas, fast food, passaram a fazer parte do hábito alimentar ocidental.

Um dos processos de resistência às mudanças tão aceleradas que surgem é o de patrimonialização. Primeiramente restrito aos bens materiais, ou seja, obras de arte, prédios históricos, etc., esse mecanismo acaba por preservar apenas uma perspectiva elitista da identidade nacional. Em um esforço de democratização, passam-se a incluir os bens de natureza imaterial entre os que formam o patrimônio nacional. É nesse ensejo que cultura alimentar passa a ser contemplada e salvaguardada.

São outros patrimônios, muito além daqueles tradicionalmente consagrados. Tão patrimônios pelo que significam e representam das muitas diferenças, da alteridade, do direito a manifestar e se reconhecer pertencendo a grupos e comunidades.

É essa a compreensão mais atual e internacional de patrimônio cultural, quando, justamente no que há de particular, próprio, diferente, marca identidade, comunica-se patrimonialmente em contextos crescentemente mundializados. (LODY, 2008, p. 424)

Outro fator determinante nesse processo é o turismo. Fenômeno social, ele ganha novas dimensões durante a modernidade. Seu crescimento em velocidade exorbitante causa distorções e o turismo de massa acaba por tomar forma colonialistas (KRIPPENDORF, 2000). Ferramenta 
de promoção do patrimônio cultural, seus efeitos também terminam sendo muitas vezes destrutivos: diante da fragilidade da comunidade local, a supervalorização patrimonial acaba por afastar os atores à cuja cultura pertence aquele patrimônio, numa dialética da construção destrutiva (COSTA, 2015).

Surgem, assim, movimentos de reação a esses desequilíbrios causados pelo turismo. E a gastronomia se une ao fenômeno nesse processo. A busca por um desenvolvimento "sustentável" (econômica, social, cultural e ambientalmente), baseado na valorização das comunidades locais e seu patrimônio alimentar apresenta-se como um caminho possível. A gastronomia regional passa a ser apresentada como um diferencial turístico e os inventários do Slow Food e as Indicações Geográficas exercem um papel preponderante nesse transcurso na Europa. Ao empoderar as populações locais e valorizar o seu território, o turismo torna-se ferramenta de desenvolvimento local e não de desequilíbrios.

Entretanto, ao analisarmos os processos de inventariação do patrimônio alimentar nacional desenvolvidos no Brasil pelo IPHAN, INPI e Slow Food, percebemos uma relação ainda incipiente com o turismo. Poucas são as iniciativas envolvendo a atividade turística como ferramenta de salvaguarda e empoderamento da população local. O que se encontra, em alguns casos, é a menção da influência do turismo na tradição alimentar, como no trecho de depoimento de Ubiratan Castro de Araújo, no dossiê do Ofício das Baianas de Acarajé, do IPHAN, que relata a transformação do bolinho frito em um sanduíche, como ele é consumido hoje.

Desde menino eu já comecei a ver o acarajé com a possibilidade de abrir e colocar o vatapá e camarão, pouco camarão, muito pouco camarão (...) Eu nasci em 1948, mas meu pai, que era da Marinha e fez a guerra aqui, contava que foi de certa forma uma influência muito americana porque a chegada dos americanos em 43/44 mudou muita coisa (...). A cidade se americanizou muito, com gestos, costumes, namoro (...) e uma das coisas foi o acarajé ter essa relação com o cachorro-quente, como sanduíche, essa coisa de vocế abrir o acarajé e colocar coisas dentro: o vatapá e o camarão, que durante muito tempo foi o padrão; nos anos 70 a influência dessas coisas de pizza, essas coisas, começaram a colocar salada que não tinha nada a ver (...). Era vatapá, camarão e pimenta, e mais recente, nos anos 80 para 90 , começaram a colocar caruru já por conta do turismo, aí vem a pressão de fora, os turistas que querem provar a comida baiana, e aí o tabuleiro fica farto, um pouquinho de caruru, um pouquinho de vatapá, um pouquinho de cada coisa, e aí vocề começa a encher com uma série de coisas para dar a oportunidade aos turistas de provar essas comidas, e o acarajé passa a ser um continente, passa a fazer um papel de pão, todas essas adaptações foram adaptações que ajudaram a modificar o acarajé (...) mas ao mesmo tempo foi esse acaraburgue que assegurou a manutenção do acarajé e uma capacidade de competição com as esfihas e com os chamados sanduíches. (BRASIL, 2007b, p. 53) 
Apesar da perspectiva positiva apresentada por Ubiratan da mudança sob influência do fluxo turístico, predomina uma percepção de receio frente a essas adaptações muitas vezes exigidas pelo mercado por parte do IPHAN e do Slow Food: há um temor de que os bens de natureza imaterial do patrimônio alimentar brasileiro se descaracterizem com tantas alterações. Esse, aliás é um dos pontos de maior conflito entre os três processos de inventariação aqui analisados. Enquanto essas duas instituições consideram as padronizações e imposições de normas sanitárias industriais para pequenos produtores artesanais uma ameaça ao patrimônio alimentar nacional, o INPI exige a adequação a tal legislação como pré-requisito para a obtenção da certificação de Indicação Geográfica.

De mais a mais, as diferenças entre os três processos de inventariação ficam claras ao longo da análise desenvolvida no capítulo anterior. Elas são metodológicas, mas também de intencionalidades e funcionalidades. Mesmo diante de perspectivas tão diferentes em relação aos produtos da cultura alimentar brasileira, acreditamos que o diálogo entre essas três instituições não só é possível, como necessário. Dessa forma, pode-se pensar em estratégias de divulgação dos bens em questão. Tornar o bem do patrimônio alimentar um produto mais atrativo para o mercado (e para o turismo, consequentemente) pode ser uma das ferramentas de salvaguarda. Essa linha de pensamento corrobora ainda com as políticas desenvolvidas pelo MTur, de turismo responsável e sustentável.

Mais do que isso, ao analisar a Política Nacional de Turismo, o programa de Regionalização do Turismo e o InvTur, percebe-se que os inventários do IPHAN, do Slow Food e o INPI ainda são subutilizados como potenciais atrativos turísticos. Na realidade, há uma completa ausência de menção a eles nos projetos desenvolvidos pelo ministério. Da mesma forma que não se percebe a possibilidade do turismo como forma de incremento para os pontos de cultura do MinC. Ou que parcerias como a de incentivo ao Turismo Rural com o MDA se restrinjam a projetos, sendo descontinuadas. Assim, é inevitável a comparação de como na história do turismo europeu, debatida no segundo capítulo, a política de regionalização foi fundamental para o desenvolvimento de um turismo gastronômico.

A cultura alimentar local apresenta-se como um dos marcos mais latentes de diferenciação de uma população. Trata-se, portanto, de um potencial produto turístico. Há alguns fatores, entretanto, que diferenciam a situação do desenvolvimento do turismo gastronômico no Brasil. O primeiro é a ausência da gastronomia como foco das políticas públicas do Turismo. A cultura alimentar ainda é tratada apenas como mais um elemento, de forma que não há um esforço em desenvolver esse potencial turístico especificamente. $\mathrm{O}$ segundo é falta de articulação entre as instituições responsáveis pela formulação e aplicação de 
políticas públicas e entre essas e os demais atores que atuam na salvaguarda do patrimônio alimentar nacional. Neste ponto entram outros fatores dificultadores, que tornam injusta a comparação com qualquer processo desenvolvido em outras partes do mundo. A tal "Sustentabilidade Político-Institucional" citada em documento do MTur ainda é um complicador no país. As políticas públicas muitas vezes ficam à mercê das mudanças no cenário político, gerando uma série de projetos e ações descontinuados. Ao analisarmos as instituições aqui reunidas, percebemos que, no fim das contas, todas estão, de uma forma ou de outra, conectadas ao governo federal. Dessa forma, mudanças políticas podem ter um peso grande na forma como tais iniciativas são ou não incentivadas e mantidas.

Qual seria, então, o caminho para se incrementar o turismo gastronômico no país? Os inventários do patrimônio alimentar brasileiro se apresentam como um potencial turístico ainda a ser desenvolvido. No entanto, há de se levar em conta que os processos de inventariação e registro são, à exceção do da Arca do Gosto, lentos; demandam tempo para abarcar a complexidade dos bens culturais. Além disso, as catalogações em questão também apresentam limitações, como a restrição à patrimonialização de receitas, ou a exigência de que um produto seja de uma área circunscrita. Nessa perspectiva, em um país de dimensões continentais como o Brasil, parece-nos que a descentralização e o empoderamento das populações locais são imprescindíveis para que se possa falar em salvaguarda da cultura alimentar nacional e incentivo ao turismo gastronômico no país.

O exemplo narrado da experiência de turismo desenvolvida pelo produtor de queijo artesanal da Canastra, Guilherme Ferreira, demonstra que quando os produtores têm condições, conseguem aliar o turismo e a cultura alimentar de forma a trazer ganhos para região. Nessa perspectiva, a valorização da comunidade local, através da gastronomia, não apenas como um atrativo simplificado, mas como um sistema cultural complexo, com diversas facetas (e atrações) apresenta-se como uma solução possível para o desenvolvimento do turismo pelo Brasil. Para isso, no entanto, é preciso ações de conscientização da potencialidade do turismo como ferramenta de empoderamento da população local. 


\section{REFERÊNCIAS BIBLIOGRÁFICAS}

ABNT. Norma Brasileira ABNT NBR 16479:2016. Rio de Janeiro: ABNT, 2016.

BARDIN, Laurence. Análise de Conteúdo. Lisboa, Portugal: Edições 70, 2002.

BARRERA, Ernesto; BRINGAS, Olivia. Rutas Alimentarias: una estrategia de negocios inclusivos que vincula las políticas agrarias y turísticas. In Études caribéennes [En ligne], 13-14 | Décembre 2009. Disponível em http://etudescaribeennes.revues.org/3828. Consultado em 19 out. 2016.

BAUMAN, Zygmunt. Ensaios sobre o conceito de cultura. Rio de Janeiro: Zahar, 2012.

BELAS, Carla Arouca. A propriedade intelectual no âmbito dos direitos difusos. In TEIXEIRA, João Gabriel L.C., et al (org). Patrimônio imaterial, performance cultural e (re)tradicionalização. Brasília: ICS-UnB, 2004.

BHABHA, Homi. O Local da cultura. Belo Horizonte: Ed. UFMG, 2003.

BIENASSIS, Loïc. Quelle carte pour quel territoire ? Impossibles et nécessaires : les inventaires du patrimoine alimentaire. Food \& History, v. 9, n. 2, pp. 127-152, 2011.

BOCK, Isabel Angelica de Andrade; TOMAZZONI, Edegar Luis. Rede Nacional De Turismo Rural: Fatores Que Dificultam Sua DinâMica Interativa. In Tourism \& Management Studies, vol. 1, 2013, pp. 123-132. Faro, Portugal: Universidade do Algarve, 2013.

BORBA, Denísia Martins. Ilê Wopo Olojukan: experiência da religião na construção da identidade cultural. In TEIXEIRA, João Gabriel L.C., et al (org). Patrimônio imaterial, performance cultural e (re)tradicionalização. Brasília: ICS-UnB, 2004.

BRASIL. Presidência da República. Constituição da República Federativa do Brasil de 1988. Brasília: 1988.

. Instituto do Patrimônio Histórico e Artístico Nacional. Inventário nacional de referências culturais: manual de aplicação. Brasília: IPHAN, 2000a.

2000b.

. Presidência da República. Decreto n 3.551, de 4 de agosto de 2000. Brasília:

. Ministério do Desenvolvimento Agrário. Programa de Turismo Rural na

Agricultura Familiar. Brasília, 2004. Disponível em portal.mda.gov.br/o/875076. Consultado em 26 out. 2016.

Instituto do Patrimônio Histórico e Artístico Nacional. Memória da quinta reunião da Câmara do Patrimônio Imaterial. Brasília: Departamento do Patrimônio Imaterial/IPHAN, 15 de dezembro de 2005.

. Instituto do Patrimônio Histórico e Artístico Nacional. Queijo Artesanal de

Minas: Patrimônio Cultural do Brasil. Dossiê Interpretativo. Brasília, DF: IPHAN, 2006. 
2007.

. Presidência da República. Decreto n⿳0 6.040, de 7 de fevereiro de 2007. Brasília:

. Instituto do Patrimônio Histórico e Artístico Nacional. Ofício das Baianas de Acarajé. Brasília, DF: IPHAN, 2007b.

. Instituto do Patrimônio Histórico e Artístico Nacional. Produção Artesanal e

Práticas Socioculturais Associadas à Cajuína no Piauí. Brasília, DF: IPHAN, 2009.

. Ministério do Turismo. Inventário da Oferta Turística. Brasília, 2011.

. Ministério da Cultura. As metas do Plano Nacional de Cultura. Brasília, 2012.

. Ministério do Turismo. Plano Nacional de Turismo 2013-2016. Brasília, 2013.

. Ministério do Desenvolvimento Social e Combate à Fome (MDS). Quilombos do Brasil: segurança alimentar e nutricional em territórios titulados. Cadernos de Estudo Desenvolvimento Social em Debate, No 20. Brasília: 2014a.

. Instituto do Patrimônio Histórico e Artístico Nacional. Modo Artesanal de Fazer

Queijo de Minas: Serro, Serra da Canastra e Serra do Salitre (Alto Paranaíba). Brasília, DF: IPHAN, 2014b.

. Câmara Interministerial de Segurança Alimentar e Nutricional (Caisan).

Indicadores e Principais Resultados do Plano Nacional de Segurança Alimentar e

Nutricional. Brasília, 2015a.

Conselho Nacional de Segurança Alimentar e Nutricional (Consea). Documento

de Referência - $5^{a}$ Conferencia Nacional de Segurança Alimentar e Nutricional. Brasília: Presidência da República, 2015 b.

. Instituto do Patrimônio Histórico e Artístico Nacional. Termo de Referência para a Salvaguarda de Bens Registrados. Brasília, DF: IPHAN, 2015c.

. Banco Nacional de Desenvolvimento Econômico e Social. CIRCULAR SUP/AGRIS No 24/2015-BNDES. Brasília, 2015d.

. Instituto do Patrimônio Histórico e Artístico Nacional. Mário e o patrimônio. 01

jul. 2015e. Disponível em: <http://portal.iphan.gov.br/noticias/detalhes/2735>. Acesso em: 13 abr. 2016.

. Ministério do Turismo. Guia Turismo e Sustentabilidade. Brasília, 2016.

BUIATTI, Stefano. Food and tourism: the role of the "Slow Food" association. In SIDALI, Katia Laura; SPILLER, Achim; SCHULZE, Birgit (ed.). Food, Agri-Culture and Tourism. Berlim: Springer Berlin Heidelberg, 2011.

CANCLINI, Nestor García. A Sociedade sem Relato: Antropologia e Estética da Iminência. São Paulo: Editora da Universidade de São Paulo, 2012. 
CAPATTI, Alberto. De la Guida Gastronomica d'Italia au Slow Food : le rôle pionnier de l'Italie en tourisme gastronomique. Revista Téoros, v. 25, n. 1/2006. Disponível em http://teoros.revues.org/1307. Consultado em 17 out. 2016.

CARRAL, Emilio et al. A Inter-Relação entre Gastronomia, Cultura, Turismo e Comércio Local em Santiago de Compostela: Primeiros Resultados. In TIBÉRIO, Manuel Luís et al. Org. III Seminário "Alimentos e Manifestações Culturais Tradicionais" - II Simpósio Internacional "Alimentação e Cultura: Tradição e Inovação na Produção e Consumo de Alimentos”. Pp. 263-276. Vila Real, Portugal: Universidade de Trás-os-Montes e Alto Douro, 2016.

CASTRIOTA, Leonardo Barci. Conservação e valores: pressupostos teóricos das políticas para o patrimônio. In GOMES, Marco Aurélio A. De Filgueiras; CORRÊA, Elyane Lins (Orgs.). Reconceituações Contemporâneas do Patrimônio. Salvador: EDUFBA, 2011.

CAZELAIS, Normand. Le tourisme gourmand : la dictature des guides? In Revista Téoros, v. 25, n. 1/2006. Disponível em http://teoros.revues.org/1303. Consultado em 18 out. 2016.

CEDRON, Claire et al. La mise en politique des Indications Géographiques et du terroir au Brésil: principaux défis et perspectives. In DELFOSSE, Clarice (dir.). La Mode du terroir et les produits alimentaires. Paris, França: Les Indes savantes, 2011.

CELLARD, André. A análise documental. In POUPART, Jean et als. A pesquisa qualitativa: Enfoques epistemológicos e metodológicos. 3. Ed. Petrópolis, RJ: Vozes, 2012.

CHARMAZ, Kathy. A construção da teoria fundamentada: guia prático para análise qualitativa. Porto Alegre, RS: Artmed, 2009.

CORBIER, Mireille. A fava e a moréia: hierarquias sociais dos alimentos em Roma. In FLANDRIN, Jean-Louis; MONTANARI, Massimo. História da Alimentação. São Paulo: Estação Liberdade, 1998.

COSTA, Everaldo Batista da. Cidades da Patrimonialização Global: simultaneidade totalidade urbana - totalidade mundo. São Paulo: Humanitas, FAPESP, 2015.

CSERGO, Julia. A emergência das cozinhas regionais. In FLANDRIN, Jean-Louis; MONTANARI, Massimo. História da Alimentação. São Paulo: Estação Liberdade, 1998.

, Julia. Quelques jalons pour une histoire du tourisme et de la gastronomie en France. Revista Téoros, v. 25, n. 1/2006. Disponível em: <http://teoros.revues.org/1297>. Acesso em: 04 ago. 2015.

DÓRIA, Carlos Alberto. Formação da Culinária Brasileira: Escritos sobre a cozinha inzoneira. São Paulo: Três Estrelas, 2014.

ELIAS, Nobert. O processo civilizador: Uma história dos costumes. Rio de Janeiro: Ed. Jorge Zahar, 1994. 
EMATER-MG; AGRIFERT. Demonstração da Notoriedade Histórica e Cultural do Serro para o Queijo Minas Artesanal. Minas Gerais: 2009.

ESPEITX, Elena. Patrimonio alimentario y turismo: una relación singular. In PASOS:

Revista de Turismo y Patrimonio Cultural, vol. 2, núm. 2, pp. 193-213 Universidad de La Laguna, El Sauzal (Tenerife), España, junio, 2004.

FALCÃO, Joaquim. Política de Preservação e Democracia. In Revista do Patrimônio Histórico e Artístico Nacional, n. 20, pp. 45-49. Rio de Janeiro: SPHAN, 1984.

FÚSTER, Luis Fernández. Introducción a la teoría y técnica del turismo. Madrid: Alianza Editorial, 1991.

GALINARI, Éder et al. Microbiological aspects of the biofilm on wooden utensils used to make a Brazilian artisanal cheese. Brazilian Journal of Microbiology v. 45, n. 2, pp.713720. São Paulo: Apr./June 2014.

GASTAL, Susana. Turismo, imagens e imaginários. São Paulo: Aleph, 2005.

GASTAL, Susana; MOESCH, Marutschka. Turismo, políticas públicas e cidadania. São Paulo: Aleph, 2007.

GEERTZ, Clifford. A interpretação das culturas. Rio de Janeiro: Ed. LTC S.A., 1989.

GENTILE, Chiara. Slow Food na Itália e no Brasil. História, projetos e processos de valorização dos recursos locais. Tese de doutorado. Centro de Desenvolvimento Sustentável, Universidade de Brasília, Brasília. 412 p. Brasília, 2016.

GIESBRECHT, Hulda O. et al. Indicações Geográficas Brasileiras: Brazilian Geographical Indications: Indicaciones Geograficas Brasileñas. Brasília: SEBRAE, INPI, 2014.

GONÇALVES, José Reginaldo Santos. Antropologia dos objetos: coleções, museus e patrimônios. Rio de Janeiro, 2007.

HALBWACHS, Maurice. A memória coletiva. São Paulo: Vértice, Editora dos Tribunais, 1990.

HALL, Stuart. Da diáspora: Identidades e mediações culturais. Belo Horizonte: Editora UFMG, 2003.

A identidade cultural na pós-modernidade. 11. Ed. Rio de Janeiro: DP\&A, 2006.

HIERNAUX-NICOLAS, Daniel; e GONZÁLEZ-GÓMEZ, Carmen Imelda. Gentrificación, simbólica y poder en los centros históricos: Querétaro, México. In Scripta Nova. Vol. XVIII, n. 493 (12). Espanha: Universidad de Barcelona, 2014.

HJALAGER, Anne-Mette; RICHARDS, Greg. Still undigested: research issues in tourism and gastronomy. In HJALAGER, Anne-Mette; RICHARDS, Greg. (ed.). Tourism and Gastronomy. London: Routledge, 2002. 
HOUAISS, Antônio; VILLAR, Mauro de Salles. Minidicionário Houaiss da Língua Portuguesa. Rio de Janeiro, RJ: Objetiva, 2003.

KRIPPENDORF, Jost. Sociologia do turismo: para uma nova compreensão do lazer e das viagens. São Paulo: Aleph, 2000.

LARAIA, Roque de Barros. Patrimônio imaterial: conceitos e implicações. In TEIXEIRA, João Gabriel L.C., et al (org). Patrimônio imaterial, performance cultural e (re)tradicionalização. Brasília: ICS-UnB, 2004.

LAVILLE, Christian; DIONNE, Jean. A Construção do Saber: Manual de metodologia da pesquisa em ciências humanas. Belo Horizonte, MG: Editora UFMG, 1999.

LE GOFF, Jacques. História e Memória. Campinas, SP: Editora da Unicamp, 1990.

LÉVINAS, Emmanuel. Entre nós: Ensaios sobre a alteridade. Petrópolis, RJ: Editora Vozes LTDA, 2004.

LODY, Raul. Brasil bom de boca: temas da antropologia da alimentação. São Paulo: Editora Senac São Paulo, 2008.

LONDRES, Cecília. Referências Culturais: Base Para Novas Políticas de Patrimônio. In BRASIL. Inventário nacional de referências culturais: manual de aplicação. Brasília: Instituto do Patrimônio Histórico e Artístico Nacional, 2000.

, Cecília. Patrimônio e performance: uma relação interessante. In TEIXEIRA, João Gabriel L.C., et al. (Org). Patrimônio imaterial, performance cultural e (re)tradicionalização. Brasília: ICS-UnB, 2004.

MAY, Tim. Social Research: Issues, methods and process. 4 ed. Berkshire, Inglaterra: Open University Press, 2011.

MEDEIROS, Ana Elisabete de Almeida. Imaterialidade criadora. In Teixeira, João Gabriel L.C. et al (org.). Patrimônio imaterial, performance cultural e (re)tradicionalização. Brasília: ICS-UnB, 2004.

MENESES, Ulpiano Toledo Bezerra de. O campo do patrimônio cultural: uma revisão de premissas. In I Fórum Nacional do Patrimônio Cultural: Sistema Nacional de Patrimônio Cultural: desafios, estratégias e experiências para uma nova gestão, Ouro Preto/MG, 2009, vol. 1. Brasília, DF : Iphan, 2012.

MINAS GERAIS. Instituto Mineiro de Agropecuária. Programa Selo Azul da Agroqualidade Projeto Pró-Queijo Canastra. Belo Horizonte: 1998.

MOESCH, Marutschka Martini. A produção do saber turístico. 2 ed. São Paulo, SP: Contexto, 2002.

NORA, Pierre. Revista Projeto História. PUC/SP, nº 10, 1993.

ORY, Pascal. L'identité passe à table. Paris, França: Presses Universitaires de France, 2013. 
POLLAK, Michael. Revista estudos históricos, Rio de Janeiro, vol. 02, nº 3, 1989. Revista estudos históricos, Rio de Janeiro, vol. 05, nº 10, 1992.

POULAIN, Jean-Pierre. Sociologias da alimentação: os comedores e o espaço social alimentar. 2. Ed. Florianópolis, SC: Ed. Da UFSC, 2013.

PRIOR, Lindsay. Using Documents in Social Research. Londres, Inglaterra: SAGE Publications, 2003.

PROCAJUÍNA. Conselho Regulador da Indicação de Procedência "Piauí". Regulamento de uso da Indicação de Procedência "Piauí". Teresina, PI: 2010.

PROUST, Marcel. Em busca do tempo perdido: no caminho de Swann. vol. 01. 3a ed. São Paulo: Globo, 2006.

RIBEIRO, José Lopes. Cajuína: informações técnicas para a indicação geográfica de procedência do Estado do Piauí. Teresina: Embrapa Meio-Norte, 2010.

RICOEUR, Paul. A memória, a história, o esquecimento. Campinas, SP: Ed. da UNICAMP, 2007.

SCARPATO, Rosario. Sustainable gastronomy as a tourist product. In HJALAGER, AnneMette; RICHARDS, Greg. (ed.). Tourism and Gastronomy. London: Routledge, 2002.

SILVEIRA, Marcos Aurélio Tarlombani da. Turismo y Sustentabilidad: Entre el discurso y la acción. In Estudios y Perspectivas en Turismo, Volumen 14 (2005) pp. 222 - 242.

SLOW FOOD BRASIL. Novo impulso para a Arca do Gosto. Publicado em 04 abril 2016. Disponível em http://www.slowfoodbrasil.com/textos/noticias-slow-food/1063-novo-impulsopara-a-arca-do-gosto. Consultado em 01 out. 2016.

SOARES, Érica B. S. et al. Análises de Dados Qualitativos: Intersecções e Diferenças em Pesquisas Sobre Administração Pública. In III Encontro de Ensino e Pesquisa em Administração e Contabilidade. João Pessoa, PB: Anpad, 2011. Disponível em: http://www.anpad.org.br/diversos/trabalhos/EnEPQ/enepq_2011/ENEPQ261.pdf. Acesso em: 07 abr. 2016.

TOURGEON, Laurier. Do material ao imaterial: Novos desafios, novas questões. In Geosabere, v. 5, n. 1, pp. 67-79. Fortaleza, CE: Universidade Federal do Ceará, 2014.

TREVISAN, Rosana (coord.). Michaelis Dicionário Brasileiro da Língua Portuguesa. São Paulo, SP: Ed. Melhoramentos, 2015. Disponível em http://michaelis.uol.com.br/. Consultado em 01 out. 2016.

UNESCO. Declaração Universal Dos Direitos Humanos. Representação da UNESCO no Brasil: Brasília, 1998. 
. Convenção para a Salvaguarda do Patrimônio Cultural Imaterial. Brasília:

Ministério das Relações Exteriores, 2006.

UNWTO. Framing Sustainable Tourism. In Measuring Sustainable Tourism (MST):

Developing a statistical framework for sustainable tourism. Meeting of the Working Group of Experts on 20-21 October 2016 Discussion Paper \#1. October, 2016.

VELHO, Gilberto. Projeto e Metamorfose: antropologia das sociedades complexas. Rio de Janeiro: Jorge Zahar Ed., 1994. 